\title{
ESTRATIGRAFIA E PEDOGÊNESE DE UMA SEQUÊNCIA DE SOLOS COM B LATOSSÓLICO E B TEXTURAL EM PIRACICABA (SP)
}

\author{
MIGUEL COOPER \\ Engenheiro Agrônomo
}

Orientador: Prof. Dr. PABLO VIDAL TORRADO

\begin{abstract}
Dissertação apresentada à Escola Superior de Agricultura "Luiz de Queiroz", da Universidade de São Paulo, para obtenção do título de Mestre em Agronomia; Área de Concentração: Solos e Nutrição de Plantas.
\end{abstract}

P I R A C I C A B A

Estado de São Paulo - Brasil

Março - 1996 
Dados Internacionais de Catalogação na Publicação (CIP)

DIVISÃO DE BIBLIOTECA E DOCUMENTAÇĀO - Campus "Luiz de Queiroz"/USP

Cooper, Miguel

Estratigrafia e pedogênese de uma sequência de solos com B latossólico

e B textural em Piracicaba (SP) / Miguel Cooper. - Piracicaba, 1996.

$141 \mathrm{p}$.: il.

Dissertação (mestrado) - Escola Superior de Agricultura Luiz de Queiroz, 1996.

Bibliografia.

1. Estratigrafia 2. Solo - Gênese - Piracicaba, SP I. Titulo

CDD 631.44 


\section{ESTRATIGRAFIA E PEDOGÊNESE DE UMA SEQUÊNCIA DE SOLOS COM B LATOSSÓLICO E B TEXTURAL EM PIRACICABA (SP)}

Aprovada em 24 de abril de 1996

Comissão Julgadora:

Prof. Dr. Pablo Vidal Torrado ESALQ/USP

Prof ${ }^{a}$ Dr $^{a}$. Selma Simões de Castro FFLCH/USP

Prof $^{\mathrm{a}} \mathrm{Dr}^{\mathrm{a}}$ Iandara Alves Mendes

/UNESP

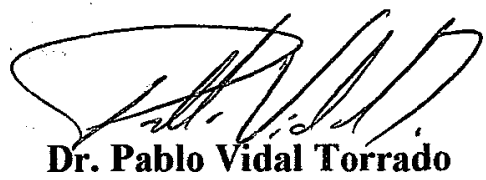

Orientador 
À LULI que com tanto amor e carinho

me apoiou neste empreendimento

OFEREÇO...

Aos meus PAIS e IRMÃOS

DEDICO. 


\section{La estrella escondida}

Las estrellas celebraron su asamblea, y cada una sacó a relucir, como saben hacer relucir las estrellas, sus propios méritos en la creación y en la vida del hombre, rey de la creación.

La estrella polar demostró como ayudaba a los hombres como fijar el norte de sus caminos y de sus mapas; el sol describió el calor, la luz, la vida que hacía llegar

a todos los hombres y mujeres de la tierra; una estrella poco conocida reveló que ella fue la que confirmó la teoría de Einstein cuando pasó oportunamente tras el sol durante un eclipse, y con ello hizo un gran servicio a la ciencia; $y$ otras mencionaron a los nombres que habian hecho famosos y los descubrimientos a que habian dado lugar. Cada una tenía algo que decir, $y$ rivalizaban en fama y esplendor.

Sólo una pequeña estrella, remota y escondida, permanecía callada en la asamblea celestial.

No se le ocurria nada que decir.

Cuando le llegó el turno y hubo de hablar, confesó que ella nada había hecho por el cosmos o por el género humano, y que los hombres y mujeres de la tierra ni siquiera la conocian, pues aún no la habian descubierto. Las demas estrellas se rieron de ella y la tacharon de inútil, perezosa e indigna de ocupar un sitio en el firmamanto.

Las estrellas están para alegrar el cielo,

$y_{\text {¿de qué sirve una estrella }}$ que ni siquiera se sabe que existe? 
La pequeña estrella escuchaba a todos los reproches que le dirigían sus hermanas, y algo se le ocurrió mientras hablaban, "¿Quién sabe?", dijo parpadeando suavemente, "a lo mejor yo también estoy contribuyendo, a mi manera, al progreso y bienestar de hombres y mujeres en la lejana tierra.

Es verdad que no me concen, pero ellos no son tontos, y sus cálculos les dicen que para explicar el curso de otras estellas y cuerpos celestes que conocen, tiene que haber todavía alguna otra estrella que con su atracción gravitatoria explique las desviaciones en los caminos de las demás.

Por eso continian estudiando e observando y buscando, y con ello avanza su ciencia y continua despierto su interés." Las otras estrella se habian callado mientras hablaba, y ella tomó ánimos con su silencio y añadió algo al final que hizo pensar a todas:

"No es que yo quiera anteponerme a nadie, y tenéis mucho mérito todas con lo que habeis hecho por los hombres y mujeres de la tierra; pero creo que yo también

les estoy prestando un servicio importante: que sepán que aún les queda algo por descubrir."

Carlos G. Vallés, S.J. 


\section{AGRADECIMENTOS}

- Ao Prof. Dr. Pablo Vidal-Torrado pela orientação, apoio, incentivo, dedicação e principalmente pela grande amizade durante todos estes anos de trabalho.

- À Escola Superior de Agricultura "Luiz de Queiroz" e ao Departamento de Ciência do Solo pela oportunidade.

- À FAPESP - Fundação de Amparo à Pesquisa do Estado de São Paulo pelo bolsa e Auxílio à Pesquisa concedidos.

- Ao Dr. Igo Fernando Lepsch pela co-orientação, ajuda e por todos esses anos dedicados à pesquisa da Ciência do Solo.

- À Prof. Dra. Selma Simões de Castro pela amizade, orientação e ajuda na descrição das lâminas delgadas.

- À Prof. Dra. Iandara Alves Mendes pela amizade, orientação e ajuda nos trabalhos geomorfológicos.

- Aos amigos Prof. Dr. Gerd Sparovek e Prof. Dr. Andreas Attila de Wolinsk Miklós pelo apoio e colaboração.

- Aos técnicos de laboratório Betty e Vladimir pela ajuda e apoio durante a realização das análises fisicas, micromorfológicas e de Raio-X, e principalmente pela amizade e confiança.

- Ao IPT pelas facilidades concedidas para realizar as fotomicrografias e ao Geólogo Jairo Sant'Anna Tadeu pela ajuda concedida.

- Aos amigos e colegas Tanaka, Kkau, Beta e B.A. pela colaboração e paciência.

- À minha familia, em especial ao meu tio Fernando que com seus conselhos e filosofia me ajudaram a ver a vida com outra perspectiva.

- A todos os que de alguma forma contribuiram para a realização deste trabalho. 


\section{SUMÁRIO}

PÁGINA

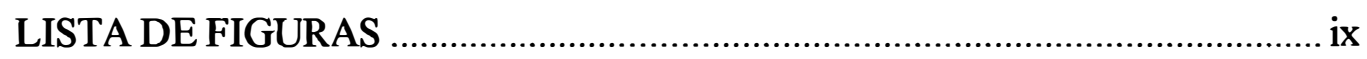

RESUMO

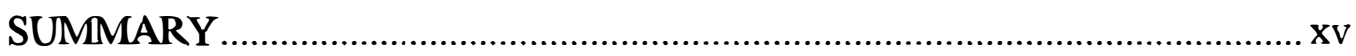

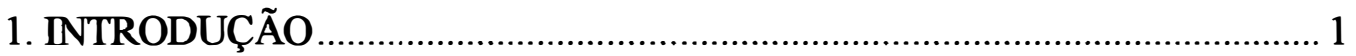

2. REVISÃO DE LITERATURA …………….............................................. (4)

2.1. Geomorfologia e geologia na Depressão Periférica ........................................ 4

2.2. Relações entre a formação de solos e o relevo ................................................ 7

2.2. Origem do horizonte $B$ latossólico........................................................... 10

2.3. Origem do horizonte $B$ textural ........................................................... 15

2.4. Origem da transição $\mathrm{Bw} / \mathrm{Bt}$ e Bt/Bw....................................................... 19

2.5. "Stonelines" e descontinuidade litológica ..................................................(23)

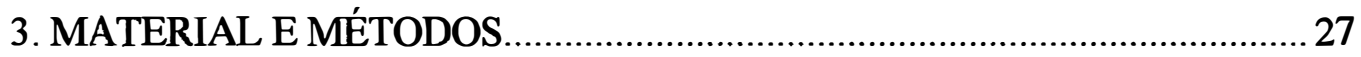

3.1. Localização e caracterização do meio físico ……………………………..... 27

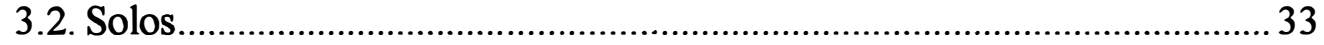

3.3. Levantamento e caracterização morfológica................................................ 35

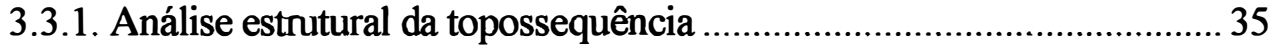

3.3.2. Estabelecimento dos segmentos da vertente ........................................ 35

3.3.3. Estabelecimento dos locais de amostragem .......................................... 35

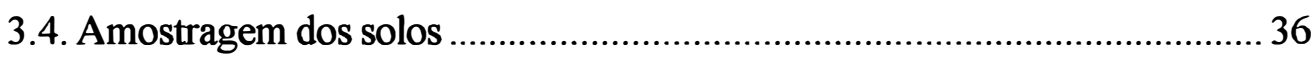

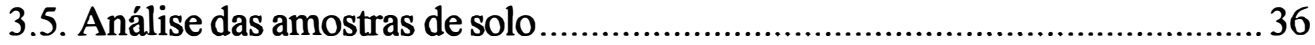

3.5.1 Análise granulométrica das amostras de solo ........................................ 36

3.5.2. Análise mineralógica da fração argila.................................................. 37

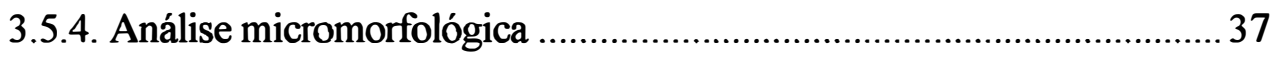

3.5.5. Determinação do zircônio, titânio, ferro e quartzo. ................................ 38

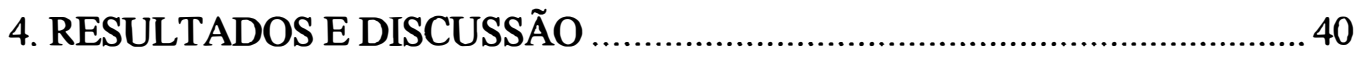

4.1. Material de origem e evolução da paisagem ................................................ 40 
4.2. Solos

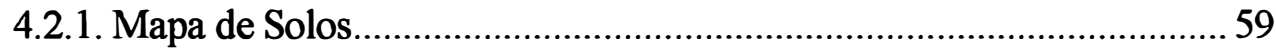

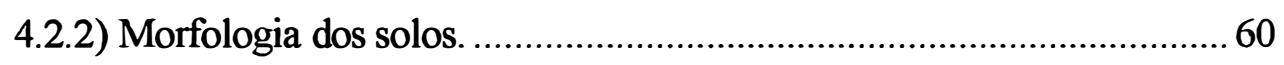

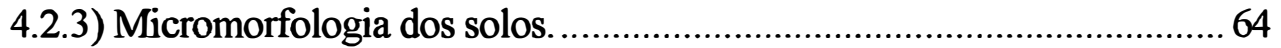

4.3) Pedogênese da estrutura microagregada e poliédrica.................................... 71

4.3.1) Origem da estrutura microagregada. ……………………….............. 82

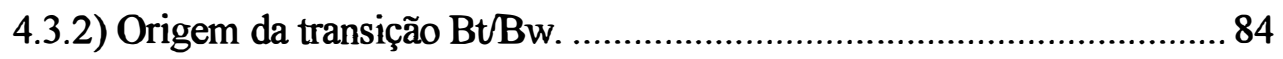

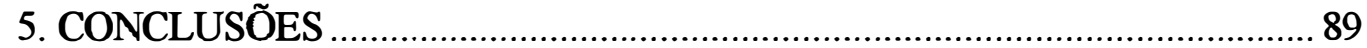

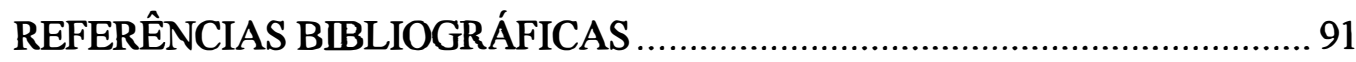

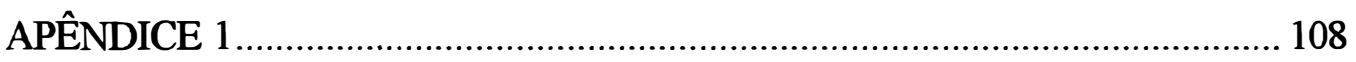

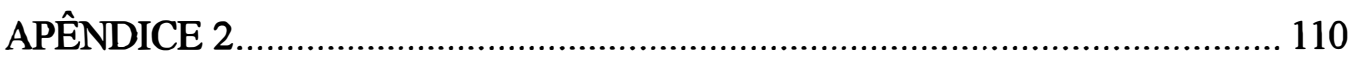

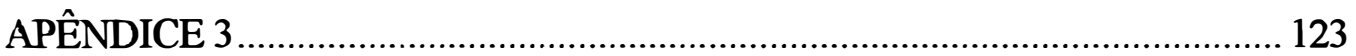

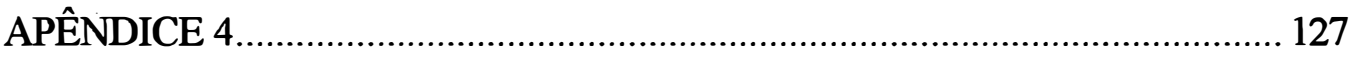

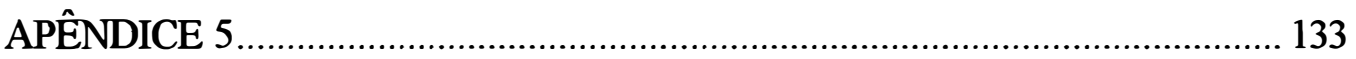

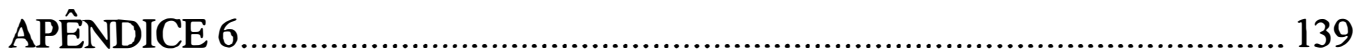




\section{LISTA DE FIGURAS}

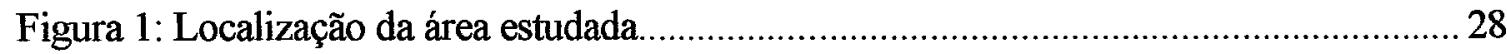

Figura 2 Mapa planialtimétrico da área estudada mostrando a posição da sequência estudada

(Corte A, B,C). Escala: 1:10000. Fonte: I.G.C. ............................................ 29

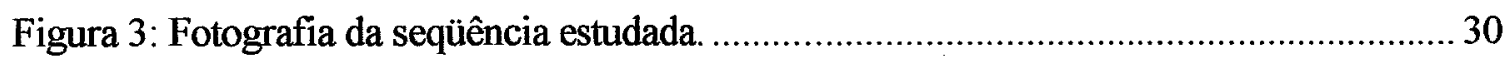

Figura 4: Balanço hídrico da região de Piracicaba........................................................... 31

Figura 5: Mapa pedológico semi-detalhado (Vidal-Torrado et al. ${ }^{4}, 1993$ ) mostrando a posição da sequência estudada (Corte A, B, C)................................................. 32

Figura 6: Perfil topográfico semi-esquemático mostrando os segmentos da vertente e respectivas classes de solos, geologia e pricipais horizontes (Bw: B latossólico; $\mathrm{Bt}$ Tb: B textural com argilas de atividade baixa; Btv: B textural com argilas de atividade alta e com algumas propriedades vérticas; $\mathrm{B} / \mathrm{Cv}$ : horizonte vértico; $\mathrm{Bp}$ Ta: Horizonte plíntico com argilas de atividade alta; $\mathrm{Bi}$ : $\mathrm{B}$ incipiente com argilas de atividade baixa) 34

Figura 7: Mapa geológico de Piracicaba extraido de IPT (1981a), ampliado sem ajustes.... 41

Figura 8: Manchas de solos originários de material básico (em roxo) que teriam formado parte de soleiras regionais e manchas de Latossolos de textura média (em amarelo e vermelho) que seriam depósitos barrados pelas soleiras. Fonte: Oliveira \& Prado (1989).

Figura 9: Evolução da estratigrafía e do relevo da região da área estudada.A) Estratigrafia hipotética apresentada antes da intrusão do sill de diabásio (Jurássico-Triássico); B) Intrusão do sill em falhas formadas durante o Permiano Superior deformando os estratos sedimentares (Jurássico-Cretáceo); C) Escavação da Depressão Periférica expondo o sill de diabásio e formando as soleiras regionais (entre o Oligoceno e Plioceno); D) Reativação de antigos falhamentos durante a formação da Depressão Periférica soerguendo o sill de diabásio e a Formação Irati e rebaixando a Formação Corumbatai; E) Deposição de depósitos arenosos finos correlatos com a Formação Rio Claro nos barramentos litológicos durante fase semiárida correlacionada com o 
glacial Danube; F) Fase de pedimentação correlato com o glacial Gunz depositando, a jusante, material retrabalhado do diabasio e da Formação Rio Claro; G) Aspecto atual da estratigrafia da região aonde esta inserida a área de estudo. ... 45

Figura 10: Gráfico mostrando a variação no teor de ferro no perfil 1 (P1)

Figura 11: Gráfico de isolinhas mostrando a variação do teor de areia total no topo da topossequência

Figura 12: Gráfico de isolinhas mostrando a variação da relação areia fina/areia grossa no topo da topossequência. 48

Figura 13: Gráficos mostrando a variação dos teores de $\mathrm{Zr}$ e Ti em dois perfis. 50

Figura 14: Gráfico mostrando a variação das relações Ti/Zr e Zr/Quartzo. 51

Figura 15: Distribuição de cinco frações de areia na tradagem profunda TP3. 53

Figura 16: Distribuição de cinco frações de areia na tradagem profunda TPC1 55

Figura 17: Distribuição de cinco frações de areia na tradagem profunda TPC2.. 56

Figura 18: Distribuição de cinco frações de areia na tradagem profunda TP11. 57

Figura 19: Gráfico de isolinhas mostrando a variação do teor de argila total no topo da topossequência 58

Figura 20: Fotografias dos perfis estudados: A) Perfil 1 (Barranco de estrada)(P1) e B) Perfil 2 (P2) e C) Detalhe da segunda "stoneline".

Figura 21: Esquema da disposição dos horizontes nos perfis estudados. 63

Figura 22: Fotomicrografia da transição entre os horizontes Bt2/Bw1 do perfil 1. Trama pórfiro-enáulica. Observa-se a coalescência de microagregados e a formação da porosidade policôncava. (28x)

Figura 23: Horizonte Bwl perfil 1. Trama enáulica. Observa-se a presença de microagregados ovais com esqueleto triado, ovais sem esqueleto triado e poliêdricos.(28x) 72

Figura 24: a) Microagregados ovais com esqueleto triado de origem biológica dentro de agrotúbulo (28x). b) Detalhe dos microagregados ovais com esqueleto triado. (138x) 
Figura 25: Horizonte Bw2, perfil 1 (P1).Trama enáulica. Quartzo subarredondado e mal selecionado.(28x) 74

Figura 26: Detalhe de um microagregado oval com esqueleto triado de origem biológica. $(28 \mathrm{x})$ 74

Figura 27: a)Transição abrupta entre uma trama porfirica e outra enáulica mostrando a fissuração do primeiro e a formação de microagregados poliêdricos por este processo (Transição Bw1/Bt3, perfil1) (28x).b) Detalhe da anterior (138x). 75

Figura 28: Transição abrupta entre a trama porfirica dos horizontes adensados e a trama enáulica característico dos horizontes Bw. (28x) 76

Figura 29: Trama porfirica fissurada, característico dos horizontes Bt adensados, formando agregados poliêdricos $(28 \mathrm{x})$

Figura 30: a) Horizonte Bt2, perfil 1. Trama porfírica fissurada mostrando a porosidade policôncava característica da coalescêmcia de microagregados.(28x) b) Detalhe da porosidade policôncava.(138x) 77

Figura 31: a) Fotomicrografia sob luz polarizada em un plano. Trama porfirica com cavidades de ocorrência comum de ferriargilãs de iluviação coalescendo os microagregados.(28x) b) Idem com nicois cruzados.(28x).

Figura 32: a) Fotomicrografia sob luz polarizada em um plano. Detalhe da figura anterior mostrando cavidades com ocorrência de ferriargilãs de iluviação e coalescendo microagregados (138x). b) Idem com nicois cruzados (138x).

Figura 33: a) Fotomicrografia sob luz polarizada em um plano. Horizonte C, perfil1 (P1). Quartzito com ferriargilãs e mangãs situado próximo à linha de pedras (28x). b) Idem com nicois cruzados $(28 \mathrm{x})$. 80

Figura 34: Fotomicrografia com nicois cruzados. Alterita, perfill. Grãos de quartzo com grau variável de esfericidade. Agregado microcristalino de quartzo formados por cristalizaçao a partir de solução. Nódulos fernuginosos em formação por segregação de Fe.(28x) 
Figura 35: Horizonte Bt1, perfil 4. Fundo matricial com grande quantidade de material intemperizável de diabásio. Presença de fragmento de diabásio.(28x) 
xiii

\title{
ESTRATIGRAFIA E PEDOGÊNESE DE UMA SEQUÊNCIA DE SOLOS COM B LATOSSÓLICO E B TEXTURAL EM PIRACICABA (SP)
}

\author{
Autor: Miguel Cooper \\ Orientador: Prof. Dr. Pablo Vidal Torrado
}

\section{RESUMO}

Numa área situada dentro da Depressão Periférica Paulista no Campus da USP em Piracicaba (SP), estabeleceu-se as relações entre os processos pedogenéticos, a morfogenéticos e a estratigrafia do topo e ombro de uma topossequência sobre diferentes materiais de origem. Varias questões foram estudadas como a origem do horizonte microagregado, a transição entre este horizonte microagregado (Bw) e outro com estrutura macroagregada poliédrica $(\mathrm{Bt})$, a origem da "stoneline" e a relação entre a evolução da paisagem e o material de origem dos solos.

O estudo foi realizado nos segmentos de topo e ombro de uma topossequência de $2600 \mathrm{~m}$ de extensão. Estudos analíticos, morfológicos e micromorfológicos foram feitos em três trincheiras no topo, ombro e começo da meia encosta e num barranco de estrada que atravessa a área. No topo tradagens profundas foram realizadas procurando estudar a origem da stoneline e a uniformidade do material. A identificação e interpretação das descontinuidades existentes entre os diferentes materiais foi realizada com base nas observações de campo, na análise estatística da distribuição das areias, nas determinações de $\mathrm{Zr}, \mathrm{Ti}$, quartzo e suas relações, e no exame micromorfológico do esqueleto.

A estratigrafia da área de estudo apresenta na sua parte mais elevada um depósito formado por sedimentos arenosos inconsolidados neocenozóicos provavelmente correlatos à formação Rio Claro (TQir) que se assentam sobre os sedimentos do permiano superior da formação Irati (Pi). Lado a lado e formando uma transição abrupta com os sedimentos arenosos, um segundo depósito neocenozóico composto por um material argiloso e vermelho assenta-se sobre parte da formação Irati (que encontra-se mais elevado junto ao sill) e um sill 
de diabásio. Descendo na vertente para o ombro e a meia encosta, o diabásio passa a ser o material de origem dos solos.

A presença de descontinuidades litológicas entre os diferentes materiais e de duas "stonelines" de origem alóctone em posições diferentes, confirmaram a existência de dois eventos deposicionais distintos, que ocorreram em períodos diferentes. Estes eventos teriam sido ocasionados pelas alternâncias climáticas que aconteceram durante o quaternário. $\mathrm{O}$ primeiro evento corresponderia à deposição dos sedimentos arenosos na forma de alvéolos escalonados durante um clima semiárido, correlacionado com a fase glacial Danube, formando o pedimento Pd1. Estes sedimentos foram transportados de posições a montante e depositados em soleiras regionais formadas pelos sills e diques de diabásio expostos durante a escavação da Depressão Periférica. O segundo evento deposicional foi caracterizado por um entalhamento posterior do pedimento Pd1, durante uma fase úmida, seguido de um processo de pedimentação durante um clima semiárido, correlacionado com a fase glacial Gunz, que depositou os sedimentos vermelhos e argilosos, originados do própio sill de diabásio, formando uma superficie pedimentar que se correlaciona com o pedimento P2.

$\mathrm{O}$ estudo da gênese dos microagregados mostrou a participação de mais de um processo na formação destes. Três processos foram evidenciados: o da ação mecânica da mesofauna formando os microagregados ovais com esqueleto triado, o da formação de microagregados ovais sem esqueleto triado por processos geoquímicos e o da físsuração do fundo matricial por processos de expansão e contração formando os microagregados poliédricos.

A transição lateral entre o horizonte Bws e Bt foi atribuida à coalescência dos microagregados provocada pela aparição de tensões durante um período mais seco que o atual. A passagem posterior para um clima mais úmido com estação seca definida, provocaria ciclos alternados de umedecimento e dessecação mais frequentes que resultam na fissuração do material formando os agregados poliédricos. Concomitantemente a estes processos, a argiluviação estaria presente, provocando a cimentação dos microagregados e preenchendo o espaço poroso. 


\title{
STRATIGRAPHY AND PEDOGENESIS OF AN OXISOL AND ALFISOL SOIL SEQUENCE IN PIRACICABA (SP)
}

\author{
Author: Miguel Cooper \\ Adviser: Prof. Dr. Pablo Vidal Torrado
}

\section{SUMMARY}

In an area situated in the Paulista Periferic Depression on the USP campus in Piracicaba (SP), the relations between the pedogenetic processes, geomorphology and stratigraphy were established on the summit and shoulder of a toposequence over different parent materials. Various topics were studied as the genesis of the microaggregate horizon, the transition between an oxic and an argillic horizon, the origin of the stonelines and the relation between the landscape evolution and the soil parent materials.

The study took place on the summit and shoulder segments of a $2600 \mathrm{~m}$ long toposequence. Analytical, morphological and micromorphological studies were done on samples taken from three pits on the summit, shoulder and the beginning of the backslope segments, and from a road cut that crosses the study area. On the summit, deep auger borings were sampled with the objective of studying the origin of the stonelines and the uniformity of the materials. Field observations, statistical analysis of the sand distribution, $\mathrm{Zr}, \mathrm{Ti}$ and quartz determinations and their relations, and the micromorphological studies of the skeleton grains, helped in the identification and interpretation of the existing discontinuities between the different materials.

The stratigraphy of the area presents, in its highest part, a deposit formed by Quaternary inconsolidated sandy sediments probably correlated with the Rio Claro formation (TQir), that overlie the Permian sediments of the Irati formation (Pi). Side by side and forming an abrupt transition with the sandy sediments, a second Quaternary deposit made up 
of a red clayey material overlies a part of the Irati formation (that appears at a higher position next to the diabase sill) and a diabase sill. Lower down, on the shoulder and backslope, the diabase appears as the soils' parent material.

The presence of lithological discontinuities between the different materials and of two stonelines of allochtonous origin in different positions, confirmed the existence of two different depositional events, that happened in different periods. These events would have been caused by the climatic changes that occured during the Quaternary. The first event would correspond to the deposition of the sandy sediments in the form of stepped alveoluses during a semi-arid climate, that correlates with the Danube glacial phase, forming the Pd1 pediment. These sediments were transported from a higher topographical position and stopped by tectonic barriers formed by the sills and dykes that were exposed during the excavation of the Peripheric Depression. The second depositional event was characterized by an later incision of of the $\mathrm{Pdl}$ pediment, during a humid phase, that was followed by a pedimentation process during a semi-arid climate, correlated with the Gunz glacial phase, that deposited the red clayey sediments, originated from the same diabase sill, forming a pedimental surface that correlates with the P2 pediment.

The study of the microaggregate genesis showed the participation of more than one process in their formation. Three processes were identified: the mechanical action of the mesofauna forming the oval microaggregates with ground skeleton, the formation of oval microaggregates without ground skeleton by geochemical processes and the fissuration of the soil matrix by expansion and compression processes forming the poliedric microaggregates.

The lateral transition between ferralic and argic horizons was attributed to the coalescence of the microaggregates due to tensions created during a drier period than present. A later change to a more humid climate with a defined dry station, provoked more frequent alternated cycles of drying and wetting that resulted in the fissuration of the material, forming poliedric aggregates. At the same time these processes occured, clay illuviation was present filling the poroso spaces and cimenting the microaggregates. 


\section{INTRODUÇÃo}

O mapeamento de solos e o entendimento dos processos que ocorrem no interior de sistemas pedológicos, são facilitados devido ao conhecimento da distribuição dos solos na paisagem. É sabido que o relevo e o substrato rochoso tem grande influência nas propriedades dos solos e que estas vão sofrer modificaçães de acordo com a posição topográfica que eles ocupam na paisagem.

Os estudos que relacionam os solos com a evolução da paisagem e a geologia auxiliam no mapeamento de solos através do estabelecimento de padrões de ocorrência que permitem prever que solos podem existir em uma área que apresenta um determinado tipo de relevo e substrato geológico. $\mathrm{O}$ estabelecimento destas relações diminue o tempo necessário para a realização dos levantamentos assim como também diminue os custos resultantes do menor número de amostras a serem coletadas.

Observa-se na Quadrícula de Piracicaba a presença de vários solos, desde solos profundos e muito intemperizados até solos rasos e pouco intemperizados, ou, de solos muito férteis até solos extremamente pobres, todos eles distribuidos nos mais diversos relevos e formados sobre diferentes materiais de origem. Esta complexidade é explicada pela presença de diferentes materiais de origem e formas do relevo que condicionam a formação de solos distintos, e que por sua vez são determinados pela estratigrafia local complexa e pelos processos geomorfológicos que esculpiram a paisagem e expuseram e/ou depositaram os diferentes materiais geológicos. 
A interpretação da morfologia da paisagem nas regiões tropicais e subtropicais baseiase principalmente nas consequências das mudanças climáticas ocorridas durante 0 pleistoceno. A alternância de climas úmidos e climas semiáridos causaram o aparecimento de forças agradacionais e degradacionais características de cada tipo de clima, que tiveram como resultado a formação da paisagem atual com seus vestígios e remanescentes de formas antigas como os pediplanos e pedimentos com seus depósito correlativos.

Atualmente, estudos voltados à explicação da forma da paisagem baseados na evolução geoquímica contestam a interpretação relativa a superficies de erosão como exclusivamente resultantes de ações mecânicas extensivas associadas a períodos semi-áridos, provocando uma polarização dos trabalhos em autoctonistas e aloctonistas. Assim uma "stoneline pode ser interpretada como remanescente de um paleopavimento detrítico resultante de uma fase semiárida posteriormente coberta por sedimentos ou como uma concentração residual ou ainda como um arranjo especial devido à atividade biológica.

Várias questões não esclarecidas nos estudos pedogenéticos em ambientes tropicais ainda permanecem sem soluções únicas e definitivas. A gênese dos Latossolos, em particular da formação da estrutura microagregada, pode-se considerar complexa devida à existência de diversas hipóteses que explicariam a sua formação. Entre elas encontramos aquelas que atribuem aos microagregados uma origem biológica, outras que atribuem uma origem geoquímica e por último aquelas que atribuem uma origem por fragmentação. A transição desta classe de solos para solos com agregados centimétricos e poliédricos pode ser explicada por três hipótese: pela coalescência de microagregados ocorrida durante épocas mais secas; por um adensamento decorrente de uma mudança na morfologia do relevo que influenciaria no fluxo lateral da agua provocando a alternância de ciclos de umedecimento e dessecamento; e por entupimento da porosidade devido à deposição de argila iluvial. A presença de "stonelines" ou linhas de pedras são atribuídas basicamente a três hipóteses: a) como base de um depósito, b) como acúmulo residual e c) como resultado do remonte biológico realizado principalmente por cupins e formigas. 
O objetivo do presente trabalho é estabelecer relações entre os processos pedogenéticos, geomorfológicos e a estratigrafia no topo, ombro e meia encosta de uma topossequência sobre diferentes materiais de origem no município de Piracicaba (S.P.). Observou-se neste local uma transição lateral abrupta entre um material arenoso fino e outro argiloso vermelho,assim como uma transição vertical e lateral entre um horizonte Bt e outro Bw.

Como questões principais a serem elucidadas estão a origem do horizonte microagregado, a transição entre este horizonte microagregado $(\mathrm{Bw})$ e outro com estrutura macroagregada poliédrica $(\mathrm{Bt})$, a origem da linha de pedras e a relação entre a evolução da paisagem e o material de origem dos solos. 


\section{REVISÃO DE LITERATURA}

\subsection{Geomorfologia e geologia na Depressão Periférica}

A Depressão Periférica é um compartimento topográfico deprimido de uma largura média de 80 a $120 \mathrm{~km}$ e com $450 \mathrm{~km}$ de extensão, que se situa entre as terras altas do Planalto Atlântico a leste e as Cuestas Basálticas a oeste (Ab'saber, 1969; Melo. \& Ponçano, 1983). A sua formação é atribuída à erosão diferencial, entre rochas sedimentares, cristalinas e os sills de diabásio, causada pela drenagem consequente e seus tributários subsequentes (Melo \& Ponçano, 1983). Segundo Penteado (1968), o subnivelamento geral dos interflúvios entre 600 e 700m os mergulhos regionais e a deposição dos eixos de drenagem permitem concluir que a região esteve sujeita a processos de aplainamento generalizado que arrasaram com o relevo, formando uma verdadeira superficie de erosão, que, segundo Melo \& Ponçano (1983) teria se formado no intervalo de tempo compreendido entre a deposição da Formação Itaqueri, correlativa da Superficie do Japi (eocênica) e a deposição da Formação Rio Claro (do início do Pleistoceno).

A Depressão Periférica corresponde à faixa de ocorrência das sequências sedimentares infrabasálticas paleozóicas e mesozóicas do Estado de São Paulo, incluindo áreas descontínuas de corpos intrusivos, sob a forma de diques e sills de diabásio (IPT, 1981b). Segundo Penteado (1968) estas camadas sedimentares mergulham numa direção geral noroeste com inclinações variáveis, maiores nas camadas basais do Grupo Tubarão e menores nas camadas do Grupo Passa Dois. A autora destaca a importância das ocorrências de perturbações devidas a falhamentos relacionadas com intrusões de diques e sills 
de diabásio ou devidas a reativamento de falhamentos, provavelmente pos-cretácicos, e à formação de vertentes dissimétricas e desniveis variados devido à estrutura homoclinal e à litologia de variada resistência face aos processos erosivos.

Melo \& Ponçano (1983) citam que o mais notável e antigo nível de aplainamento da Depressão Periférica é representado pela superficie que nivela os topos das colinas sedimentares em torno de 690-720m. Martonne (1943) a denominou como Superfície Neogênica e Penteado (1968) a denominou como Superfície de Urucaia. Este nível corresponderia ao pediplano Pd2 descrito por Bigarella et al. (1965) e ao nível planáltico B descrito por Melo (1995).

Ligeiramente embutida abaixo da Superfície Urucaia encontra-se, entre 580-630m, a superficie alveolar, que constitui o assoalho da Bacia do Rio Claro, denominada Superficie Rio Claro (Penteado, 1968), que corresponderia ao pediplano Pd1 segundo o modelo de Bigarella et al. (1965) e ao nível planáltico Bd de Melo (1995). A mesma autora observou que esta superficie encontra-se desnivelada em alvéolos escalonados, separados por soleiras associadas a falhas. Melo \& Ponçano (1983) atribuem esta superficie a uma fase de aplainamento posterior à que formou a Superficie Urucaia, correspondendo esta ao início do Pleistoceno, mais provavelmente à fase de morfogênese mecânica associada à glacial Danube. Melo (1995) explica a formação deste nível pedimentar no vale do Rio Corumbataí, como sendo resultado da erosão facilitada pela ocorrência de litologias mais brandas (rochas sedimentares) cercada por derrames e soleiras de rochas básicas e de pulsações tectônicas na estrutura de Pitanga, com alternância de discretos movimentos ascendentes e descendentes, favorecendo a erosão remontante.

Bjornberg \& Landim (1966) identificaram três níveis sedimentares diferentes. Para o nível inferior, que se encontra entre $600-800 \mathrm{~m}$, os autores propuseram a designação de Formação Rio Claro. A deposição destes sedimentos da Formação Rio Claro levaram à formação da superfície homônima (Penteado, 1968; Melo \& Ponçano, 1983). 
A Formação Rio Claro foi depositada, segundo Melo \& Ponçano, 1983, em uma fase de morfogênese mecânica, mas a cumulação ter-se-ia dado graças a barramentos tectônicos. Anteriormente, Penteado (1968) havia explicado que a presença de soleiras locais, remanescentes de fases semiáridas pretéritas, criaram zonas levemente deprimidas devido ao reativamento neocenozóico de falhas e fraturas por basculamentos e a uma modificação do clima para semiaridez, que teriam sido os fatores responsáveis pela interrupção da rede de drenagem em bacias alveolares escalonadas. Segundo a mesma autora, esses alvéolos, ao longo de antigos eixos de drenagem, concentravam um escoamento centrípeto, temporariamente endorreico, permitindo a deposição regional. Estas condições de semiaridez com chuvas intensas e episódicas deram origem, segundo a autora, a um escoamento torrencial e desorganizado formando verdadeiros lençóis de lama de fraca aptidão seletiva, que teriam sido os responsáveis pela deposição das cascalheiras de quartzo na base da formação.

Entre o topo aplainado das colinas, que corresponderiam aos pediplanos Pd2 e Pd1, e o assoalho, geralmente plano das várzeas, Penteado (1968) ressaltou a presença de níveis intermediários que se repetem por toda a Depressão Periférica. Esses níveis, que frequentemente se encontram recobertos de cascalheiras, correspondem a patamares desdobrados em número de 2 a 4, que indicam, segundo a autora, fases sucessivas de aplainamento lateral e entalhe, oriundas de alternâncias climáticas e lento tectonismo positivo entre o Pleistoceno e o Holoceno (Bigarella et al., 1965; Melo \& Ponçano, 1983).

Segundo Bigarella et al. (1965), na época em que iníciou-se a pediplanação do Pd1, a paisagem encontrava-se muito dissecada, resultado da época úmida anterior. A mudança climática para o semi-árido, provocou a remoção desordenada do regolito para as depressões do terreno por processos de movimento de massa e corridas de lama, provocando o entupimento da calha de drenagem contribuindo para um levantamento do nível de base local. Este nível de base passou a controlar os processos de morfogênese mecânica, responsáveis pela elaboração do pediplano Pd1. Após o término da fase semiárida que 
originou o pediplano Pd1, seguiu-se uma fase úmida responsável pela dissecação e remoção de grande parte do material sedimentado durante a elaboração do Pd1, subsequentemente instalou-se uma nova fase semiárida, durante a qual processos de pedimentação modelaram o pedimento P2. Posteriormente, após nova alternância de fases úmidas e semiáridas, estes autores, descreveram a formação do pedimento P1. Estes pedimentos corresponderiam aos patamares desdobrados de Penteado (1968). Melo \& Ponçano (1983) atribuiram a formação destes pédimentos às fases semiáridas dos glaciais Gunz e Mindel ou Kansan e Illinoian, segundo Bigarella \& Mousinho (1965b), respectivamente. O pedimento P2 foi descrito por Melo (1995) como o nível planáltico R, e explicou que no vale do Rio Piracicaba este nível é fortemente controlado por soleiras de diabásio que ocorrem na altura da cidade de Piracicaba.

Após a formação do nível pedimentar P1 seguiu-se uma nova fase úmida de dissecação da paisagem e recobrimento florestal. Com o retorno das condições de semiaridez, agora com um caráter talvez mais moderado ou de menor duração, restabeleceram-se os processos de morfogênese mecânica, em duas etapas distintas que correspondem aos glaciais Riss e Wurm, entremeadas de uma fase de dissecação em clima úmido, que formaram dois níveis de baixos terraços com cascalheiros Tc2 e Tc1 (Bigarella et al., 1965).

\subsection{Relações entre a formação de solos e o relevo}

Os fatores de formação de solos foram definidos por Buol et al. (1980) como sendo os agentes, forças, condições, ou relações, ou combinações destes, que influenciam, influenciaram ou que vão influenciar o material de origem de um solo, com o potencial de transformá-lo. 
Assim, Dokuchaev ${ }^{1}$ em 1898 (Buol et al., 1980) sugeriu que a formação de solos estava condicionada por quatro fatores: clima, organismos, substrato geológico e tempo. Ele resumiu estes fatores numa equação:

$$
S=f(c l, o, p)^{t}
$$

Jenny (1941) adicionou aos quatro fatores de Dokuchaev, o fator relevo. Este autor formulou uma equação que estabelecia a relação entre certos atributos dos solos e os fatores.

$$
\text { S ou } s=f(c l, o, r, p, t, \ldots)
$$

onde $\mathrm{S}$ é o solo, s é um atributo do solo, cl é o clima, o são os organismos, r é o relevo, p é o material de origem e $\mathrm{t}$ é o tempo. Os pontos após o $\mathrm{t}$ significam fatores não especificados. Para determinar a dependência de um atributo do solo num determinado fator, Jenny reescreveu a equação resolvendo-a para cada fator, onde só um fator varia enquanto os outros permanecem constantes.

Johnson \& Watson-Stegner (1987) propuseram um modelo compreensivo de gênese de solos baseado na observação de que solos evoluem através de dois caminhos: progressivo (P) e regressivo (R). Para todos os solos, $S=f(P, R)$. O caminho progressivo inclui processos e fatores que promovem a horizontização, desenvolvimento construtivo e/ou o aprofundamento sub-superficial. O caminho regressivo inclui processos e fatores que promovem-a haploidização, o crescimento retardado e/ou a remoção superficial. A ação cenjunta dos caminhos $\mathrm{P}$ e $\mathrm{R}$ podem alternadamente predominar um sobre o outro, à medida que o solo evolui.

${ }^{1}$ DOKUCHAEV, V.V. Russian Chernozem (Russkii Chernozem), 1898. Israel Prog. for Sci. Trans., Jerusalem. 1967. 
O progresso dos estudos pedológicos mostrou que o modelo de Simonson (1959) era limitado. Este considera que a diferenciação de horizontes de um perfil de solo é devido a quatro processos no sistema solo: adição, remoção, transferência e transformação. Os estudos das últimas décadas tem mostrado que os solos formam um contínuo na paisagem e que processos que ocorrem nas partes mais elevadas do relevo influenciam os solos que ocorrem na parte mais baixa do relevo (Hall, 1983).

O relevo local controla a distribuição dos solos na paisagem a tal ponto que solos com características morfológicas e propriedades contrastantes convergem lateralmente e se encontram em equilibrio sob as condições locais. Muitas das diferenças entre solos situados em posições topográficas diferentes, são devidas a combinações de microclima, pedogênese e processos geológicos sub-superficiais. Diferenciar os efeitos de cada um na distribuição de solos é normalmente difícil (Birkeland et al. 1990).

A utilidade do estudo dos solos através das topossequências está no reconhecimento das relações espaciais entre os horizontes e suas transições verticais e laterais ao longo das vertentes que refletem uma hierarquia e uma cronologia no processo pedogenético. Quando o arranjo (geometria) desses horizontes evidencia concordância ou discordância com as superficies topográficas das vertentes torna-se possível avaliar as relações entre solo e relevo, bem como as relações destes com a paisagem onde se encontram (Boulet et al., 1994) e deduzir a história e características do meio. A interação dos solos com as formas do relevo e o resultado dos processos pedológicos e geomorfológicos são a chave para o entendimento das topossequências, razão porque este conceito tem sido tão importante nos estudo de solos (Gerrard, 1981).

Segundo Hall (1983), o movimento da água na paisagem é a causa principal para a distribuição de matéria nas encostas. $\mathrm{O}$ movimento da água e sua distribuição controlam a diferenciação dos solos na paisagem. Birkeland (1984) explicou que a geoquímica do solo pode variar com a posição no relevo se a quantidade de água que entra por precipitação é suficiente para causar uma redistribuição da água no solo através da encosta. Gerrard (1981) 
em seu trabalho sobre catenas complementou que cada catena é o resultado de interrelações complexas entre o solo e os processos que ocorrem na encosta, estes sendo governados por taxas diferenciais de erosão e deposição que ocorrem em diferentes partes das encostas. Segundo este autor, do ponto de vista pedogenético, todo relevo consiste em zonas de remoção, transferência e acúmulo.

Ruhe (1960) apresenta seu modelo compartimentando as vertentes em cinco segmentos, explicando os processos que ocorrem nestes. Os cinco segmentos são: topo, considerado o segmento mais estável da vertente onde o movimento da água é predominantemente vertical e como conseqüência apresenta solo profundos e homogêneos; ombro, que tem forma convexa com maior intensidade do "runoff" resultando num segmento de alta erodibilidade e instável, predominando a formação de solos rasos; escarpa, o processo dominante é o transporte de material assim como da água tanto em superficie como em subsuperficie resultando também na formação de solos rasos; sopé, com sua forma côncava e deposição de material trazido da parte mais elevada, este segmento é de acúmulo e relativamente instável formando solos heterogêneos; e finalmente o declive aluvial, solos nesta posição são altamente variados sendo formados por material trazido dos segmentos superiores da encosta assim como de materiais trazidos e depositados pelo rio.

Vários trabalhos estudando as relações solo-relevo utilizaram este modelo de vertente. Exemplos destes são os trabalhos de Malo et al. (1974),Curi \& Franzmeier (1984), Vidal-Torrado (1989), Kreznor et al. (1989), Graham et al. (1990), Graham \& Buol (1990), Pierson \& Mulla (1990) e Honeycutt et al. (1990).

\subsection{Origem do horizonte B latossólico}

O horizonte B latossólico é o horizonte diagnóstico dos Latossolos e aparece em alguns solos intermediários, como por exemplo a Terra Roxa Estruturada Latossólica e o Podzólico Vermelho-Escuro Latossólico. Este horizonte caracteriza-se por ser muito 
homogêneo. Morfologicamente pode apresentar estrutura maciça ou em blocos subangulares fracos que se desfazem em microagregados de grau forte no caso de apresentar textura argilosa. São horizontes altamente intemperizados com poucos minerais intemperizáveis nas frações areia e silte. A fração argila apresenta uma mistura de caulinita e óxidos e hidróxidos de ferro ou alumínio. (Buol \& Eswaran, 1978; Stoops, 1983).

Os microagregados, elementos característicos de um horizonte latossólico, podem apresentar várias formas: esféricas, ovais ou poliédricas. Existem diversos estudos sobre a formação destes tipos de agregados que mostram origem diversa (Buol \& Eswaran, 1978; Stoops, 1983; Stoops \& Buol, 1985).

Beadou (1972) estudando os solos ferralíticos da Republica Centro-Africana observou que os microagregados estão intimamente ligados à pedogênese ferralítica e que apresentam uma estrutura complexa com um núcleo rico em óxidos e hidróxidos de ferro envolvido por uma camada de fundo matricial pouco modificado. A formação de microagregados é acompanhada por uma modificação do plasma que pouco a pouco vai se individualizando e passa de massépico para insépico ou assépico. Ele explica que a porosidade fissural que existe quando os microagregados são formados se transforma em porosidade de empilhamento onde os microagregados estão bem individualizados. Em trabalhos posteriores este autor observou uma intensa fissuração do plasma nos horizontes superficiais originando os microagregados em solos do Gabón (Beadou et al., 1977) e em 1987, novamente na República Centro-Africana, Beadou et al. (1987) concluíram que os microagregados resultam da combinação de argilas com a hematita e que as argilas estão orientadas paralelamente às bordas dos agregados.

Pedro et al. (1976) explicaram a formação da microestrutura ovóide dos Latossolos como sendo de evolução geoquímica. Eles propõem que o processo de pedogênese ferralítico é formado por dois estágios principais. O primeiro corresponde à alteração ferralítica havendo neoformação de um material ferrocaulinítico. O segundo corresponde ao desenvolvimento de um horizonte microagregado típico devido ao total desaparecimento dos 
minerais primários da rocha e da individualização de um complexo de alteração essencialmente caulinítico-gibbsítico e à ocorrência de fenômenos secundários como a dessaturação do complexo de adsorção, a ferritização do complexo argiloso e uma cristalização progressiva dos compostos ferríferos independentes.

Muller (1977) em trabalho conduzido na República de Camarões, explicou a formação dos horizontes óxicos devido a uma pedogênese recente ou atual. Mostrou que os microagregados esféricos são formados por um simples rearranjamento do plasma sem que apareçam mudanças na cor devido a eventuais deslocamentos do ferro. Este processo parece ser uma fragmentação física que ocorre a partir dos horizontes mais profundos em direção à superficie e aparece como uma reorganização biaxial de uma estrutura insépica ("neostrians"), sem que ocorra nenhuma transformação de natureza geoquímica. $O$ autor classifica os microagregados em cinco tipos: estruturais, formados a partir do processo de microestruturação ou separação do plasma; relictuais, herdados do processo de intemperismo; ferríticos, formados por um processo de ferritização anterior; zoogenéticos; formados pela pedoturbação de origem biológica e complexos, que são formados pela agregação de microagregados de tamanho menor.

A formação de microagregados poderia ocorrer segundo Chauvel et al. (1978) a partir de uma matriz anisotrópica composta de caulinita e hidratos de ferro. Zonas pequenas $(100 \mu \mathrm{m})$ de cor mais vermelha estariam-se formando, nesta matriz, como resultado de uma organização diferencial do ferro. Estes micronódulos se individualizariam quando a matriz que os circunda desaparece devido à sua alta mobilidade, como resultado da deferrificaçãoparcial.

Utilizando técnicas de microscopia ótica e eletrônica para a observação dos microagregados feitos pelos cupins em amostras coletadas na Costa de Marfim e Congo e de material produzido pelos cupins em laboratório, Eschenbrenner (1986) determinou_a microfábrica, a composição geoquímica e mineralógica dos microagregados. Ele observou que estes microagregados eram orgânicos ou minerais ou ambos e que apresentavam a forma 
característica oval a esféricos. Com isso ele concluiu que este material formado pelos cupins é muito similar aos microagregados encontrados nos Latossolos, podendo resultar da atividade dos cupins em condições tropicais, processo que ele chamou de bioagregação. Vários trabalhos mostram o papel secundário da formação de microagregados pela mesofauna do solo (Chauvel, 1977; Muller, 1977; Stoops, 1983; Trapnell \& Webster, 1986). No entanto Eschenbrenner foi um dos primeiros a dar uma importância maior a este processo de formação de microagregados. Em trabalho recente no Brasil, Miklós (1992 e 1993) observou a formação de microagregados ovais por cupins em solos formados sobre basalto em Botucatu (SP), ressaltando a importância deste processo na formação de Latossolos. Vidal-Torrado (1994) observou a presença de microagregados de origem biológica em uma topossequência no distrito de Tupi, Piracicaba (SP).

Trapnell \& Webster (1986), estudando solos no leste e centro da África, observaram quatro tipos de microagregados. Os fragmentários formados pela fissuração de pedes maiores por alternâncias de ciclos úmidos e secos, os granulares que são microagregados irregulares que são formados por umedecimento gradual, granuliformes que desenvolvem superficies arredondadas após umedecimento gradual e microgranulares tendo forma quase esférica e que se formariam por processos geoquímicos ou pela atividade da mesofauna.

Fazendo uma caracterização energética dos sistemas plásmicos dos grandes conjuntos pedogenéticos, Pedro (1987) estabeleceu dois grandes conjuntos: no primeiro ocorre um meio pouco contrastante energeticamente ( $\mathrm{pF}$ variando de 1 a 2 ) onde a umidade relativa do ar é alta e as temperaturas maiores que $0^{\circ} \mathrm{C}$ e no segundo o meio é contrastante energéticamente devido à existência de estações climáticas muito distintas durante o ano $(\mathrm{pF}$ variando de 0 a 6). No primeiro caso ocorre um fenômeno convergente. Neste caso encontrase um meio úmido, muito filtrante, com soluções diluídas onde os elementos $\mathrm{Al}$ e $\mathrm{Fe}$ tem um papel fundamental nas interfaces, em função da sua hidrofobia. Todos estes parâmetros se conjugam para elaborar organizações com geometria fixa (esféricas ou ovais) e que 
aparecem geralmente sob formas de volumes com superficies externas mínimas e com dimensões compatíveis (100um) com os fenômenos físicos preponderantes.

Cambier $^{2}$ na sua tese de doutorado, citado por Pedro (1987), mostrou que nos Oxissolos as partículas de caulinita formam policristalitos formando unidades chamados de micro-domínios (lum de diâmetro). Estes policristalitos se formam pela união de cristais de caulinita dispostos paralelamente e ligados uns aos outros por pontes de Fe. Estes microdomínios orientados são a base para a formação dos micro-nódulos característicos dos Oxissolos.

Num trabalho semelhante e utilizando técnicas de sub-microscopia Santos et al. (1989) estudaram a composição de microagregados e o arranjo das suas partículas. Observaram que o mineral de argila dominante é pouco cristalino, densamente empacotado, caulinítico e orientado ao acaso. Oxi-hidróxidos de $\mathrm{Fe}$ pouco cristalinos (provavelmente ferridrita) existem como agregados individuais preenchendo o espaço entre as partículas de caulinita e a matéria orgânica tem um papel importante na união das partículas de argila. Concluíram os autores que as análise de seções ultradelgadas sugerem que a combinação de partículas de argilas orientadas ao acaso, a matéria orgânica e os agregados de Fe dão aos microagregados, uma natureza isotrópica.

Três condições foram propostas por Dexter (1988) para a formação de microagregados. Primeiro, quaisquer ligações existindo entre as partículas do solo devem ser quebradas por processos mecânicos; segundo, a físico-química do solo deve ser tal, que aglomerados de partículas de 10-20um de diâmetro possam se formar; e terceiro, o potencial da água deve ser suficiente para formar meniscos entre os aglomerados para juntá-los e formar microagregados de até $150 u m$.

${ }^{2}$ CAMBIER, P. Organisation des constituants et interactions physicochimiques au sein des microagrégats de sols. Application au système ferralitique kaolinite-oxyde de fer. Thése Paris, INRA, 226p. 1986. 
Beauvais \& Tardy (1991), estudando a degradação de couraças ferruginosas em clima tropical úmido sob floresta, afirmaram que o desmantelamento das couraças resulta de um efeito conjugado da umidade (precipitações anuais maiores que $1600 \mathrm{~mm}$ ), da decomposição da matéria orgânica e da respiração das raízes que provocam a hidratação e redução, responsáveis pela transformação da hematita em goetita, da caulinita em gibbsita e da dissolução seletiva do ferro através da ligação com o alumínio. Concluíram que em todos os lugares onde ocorre o desenvolvimento de uma floresta a formação de solos ferralíticos micronodulares ocorre às expensas de couraças ferruginosas formadas no passado sob clima tropical muito contrastante.

Vidal-Torrado (1994) observou que na área de estudo no distrito de Tupi, Piracicaba (SP), a formação de microagregados poderia ter ocorrido por mais de um processo. Ficou evidenciado nas descrições realizadas por ele o processo de microestruturação (Muller, 1977), ação da mesofauna e microagregados herdados do retrabalhamento do material latossólico ocorrido na evolução do vale.

\subsection{Origem do horizonte B textural}

O horizonte B textural é um horizonte mineral subsuperficial onde houve incremento de argilas orientadas ou não. Vários processos podem explicar esta distribuição das argilas. Birkeland (1984) citou três processos para a formação deste horizonte: o primeiro seria que os constituintes das argilas são derivadas do intemperismo que ocorre na parte superior do perfil e que se movem para baixo em solução com a água que percola e precipitam como minerais de argila no horizonte $\mathrm{B}$; o segundo refere-se às argilas formadas "in situ" pelo intemperismo de minerais no horizonte B; e o terceiro refere-se às argilas que se movem como partículas em suspensão na água de percolação e que se acumulam no horizonte $\mathrm{B}$ devido à floculação ou a constrições nos poros através dos quais a água se move. 
Adicionou o autor que sem dúvida as argilas encontradas no horizonte $B$ são formadas pelos três processos, mas que a importância relativa de cada um deles varia com o tipo de solo.

Eswaran \& Sys (1979) explicaram a formação do horizonte Bt como sendo resultado de três processos: dispersão, translocação e acumulação, dando ênfase à presença de cerosidade e à presença de cutans como características principais para a classificação destes horizontes como $\mathrm{Bt}$.

Nettleton et al. (1969) encontraram vários solos que apresentavam acúmulo de argila no horizonte $\mathrm{B}$ e cerosidade no campo e que não apresentavam cutans de iluviação nas lâminas delgadas. Explicaram este fato por duas razões: primeiro, a formação de argilas orientadas "in situ" pela ação de ciclos de molhamento e secamento ("stress cutans") e segundo, estes mesmos processos de expansão e contração podem provocar a destruição dos "cutans" de iluviação ou não formar superficies de "pedes" suficientemente permanentes como para permitir o acúmulo e formação destes "cutans".

Isbell (1980) num trabalho de revisão sobre o conceito de Bt já concluira que apesar de que a iluviação de argila possa ser evidenciada no campo, havia também evidência crescente de que sem o estudo de lâminas delgadas a sua identificação é difícil. Os estudos revisados por este autor mostraram que às vezes havia uma falta de correlação entre a cerosidade observada no campo e a quantidade de cutans de iluviação observada nas lâminas delgadas.

Para identificar horizontes Bt no campo Fedoroff \& Eswaran (1985) apresentaram três características das quais uma ou mais podem ser utilizadas para caracterizar um Bt. Estas são: presença de um horizonte eluvial acima do horizonte $\mathrm{Bt}$, presença de uma estrutura primária com estrutura secundária ou terciária em blocos e ausência de microgrânulos característicos dos Latossolos. Segundo estes autores, a argila nos horizontes Bt pode se originar: a) de um material transportado e misturado no solo; b) de um material intemperizado; c) de um material iluviado fino misturado pela fauna do solo; d) de um material herdado de um horizonte óxico; e) de feições pedológicas na forma de cutans de 
iluviação ou preenchimentos correpondendo à argiluviação presente; f) de fragmentos de feições argilosas provavelmente herdados do material de origem e formados quando o horizonte foi perturbado ou transportado; e f) de feições pedológicas perturbadas correspondentes a argiluviações passadas.

Pedro (1987) explicou a formação de macroestruturas em um meio onde encontram-se períodos energeticamente contrastantes devido à existência de estações opostas (variações de $\mathrm{pF}$ durante o ano de 0 a 6) provocando a ação de forças de cisalhamento consecutivas aos fenômenos de expansão por ocasião de cada ciclo de reumectação sazonal.

O processo de degradação do horizonte Bt é considerado por vários autores como um processo importante na formação deste horizonte. Jimenez Rueda \& Demattê (1988) observaram a presença de silãs, que podem indicar a sílica liberada da estrutura do mineral de argila. Castro (1989) observou a degradação do topo do horizonte Bt por uma depleção química do ferro seguida de uma mecânica que deixa bandas onduladas residuais de acumulação dupla no seio do horizonte E. Dijkerman \& Miedema (1988) estudando solos de Serra Leone explicaram que o aumento de argila desde o horizonte $\mathrm{A}$ para $\mathrm{o} \mathrm{Bt}$ foi devida à iluviação de argila, a diferenças texturais devido à sedimentação e à destruição de argilas do topo do Bt pelo processo de ferrólise (Brinkman, 1970). Vidal-Torrado et al. (1991) estudando um Podzólico Vermelho Amarelo observou a degradação do horizonte Bt evidênciado por mecanismo pedogenético ocorrendo sucessivamente iluviação de argila, redução da porosidade do topo do $\mathrm{Bt}$, encharcamento temporário do topo do $\mathrm{Bt}$ e degradação ou remoção lateral dos finos do topo do Bt.

Estudando Nitossolos no Quênia, Sombroek \& Siderius (1976) não encontraram na literatura um processo específico para a formação destes solos. Os processos responsáveis pela formação de Ferralsolos e Acrisolos/Nitossolos respectivamente (ferralitização versus argiluviação) não explicam satisfatoriamente a morfologia e características dos Nitossolos. Para poder entender os processos que levaram à formação destes solos, estes autores salientaram que um bom começo para delinear um processo específico é a ocorrência geral 
de agregados em blocos muito estáveis e suas superfícies brilhantes características, que também ocorrem nas alteritas. Mas, a informação existente para a formação dos pedes em forma de blocos é pouco conclusiva. A ocorrência de superficies lisas e brilhantes devido à argiluviação parece altamente improvável, não só por sua ocorrência nas partes mais profundas do perfil, mas também pela sua composição (óxidos de ferro e manganês). Segundo estes autores a formação destas superficies lisas e brilhantes resulta de processos de difusão causando concentrações de plasma na forma de cutans compostos (ferrans, mangans), localmente cobertos por argilans, não condiz com as condições aeróbicas nas quais os Nitossolos se encontram. Atribuir a formação destas superfícies a processos de estresse não explicaria a concentração dos óxidos, pois estes se movem dentro da matriz dos pedes sob condições de drenagem livre. Os autores propuseram que a migração de óxidos ocorre sob a influência de micro-magnetismo induzido por um pequeno cisalhamento entre os pedes, processo que denominaram de "metalização".

Sombroek \& Siderius (1981) consideraram que vários processos ocorriam na formação destes Nitossolos: formação de argila de atividade baixa (caulinita e sesquióxidos); translocação de argilas; homogeneização pela fauna do solos (cupins, formigas, vermes, etc.), particularmente evidente nos primeiros $100 \mathrm{~cm}$ do solo causando a destruição ou deformação de cutans e a formação de estrutura granular a estrutura em blocos subangulares; e a "nitidização", processo que causa a formação de estrutura em blocos angulares bem definidos com superficies brilhantes que podem ser lisas ou estriadas. Evidências micromorfológicas mostraram a presença de "argilans" nos pedes, enquanto que a estriação nas mesmas superfícies indicam que a micro-expansão e micro-contração podem resultar em faces de pressão ou micro-slickensides.

Estudando as propriedades micromorfológicas dos Nitossolos, Creutzberg \& Sombroek (1987) definiram uma combinação de propriedades micromorfológicas que chamaram de "Nito-argillic Syndrome", que caracterizam o horizonte nito-argílico. Dentro das características apresentadas pelos autores, destaca-se a formação de ferri-argilans finos 
nos poros como sendo a feição que mais caracteriza o horizonte nito-argílico, chamando-os de "lepto-coatings". Eles explicam a formação destes "lepto-coatings" como sendo resultado da reorganização local (estresse) de argilas silicatadas orientadas anteriormente depositadas dentro do horizonte. A omni-presença dos "lepto-coatings" no horizonte nito-argílico combinado com a ocorrência de superfícies de fraqueza no fundo matricial, podem ser considerados responsáveis pela presença de superficies lisas e brilhantes que caracterizam o horizonte nito-argílico no campo.

Sombroek (1990) reafirmou os processos que originam a formação dos Nitossolos como a presença de alguns poucos ferri-argilans de iluviação e uma maior abundância de "lepto-coatings" nos poros. Admitiu entretanto que a natureza exata das superficies brilhosas nos pedes e ainda incerta (exudação, metalização, cisalhamento, e/ou iluviação), assim como a origem das formas dos pedes.

\subsection{Origem da transição $\mathrm{Bw} / \mathrm{Bt}$ e $\mathrm{Bt} / \mathrm{Bw}$}

Na paisagem encontram-se dois tipos de transições laterais do tipo $\mathrm{Bw} / \mathrm{Bt}$ : uma onde ocorre a transição entre o horizonte com estrutura microagregada $(\mathrm{Bw})$ para o horizonte com estrutura poliédrica de acúmulo de argila $(\mathrm{Bt})$ e outra onde encontra-se a transição de horizontes com estrutura poliédrica de acúmulo de argila $(\mathrm{Bt})$ para o horizonte com estrutura microagregada (Bw).

Lepsch \& Buol (1975) estudando uma topossequência Oxissolo-Ultissolo associaram os Oxissolos às superficies mais antigas e os Ultissolos às mais jovens. Concluíram que o horizonte óxico se formava a partir da floculação e compactação do plasma formando microagregados, sendo homogeneizado por processos de pedoturąbação enquanto que o desenvolvimento dos horizontes argílicos devia-se principalmente ao processo de translocação de argilas. Outros trabalhos também citam a importância da 
translocação da argila na formação de horizontes argílicos em Ultissolos e Alfissolos (Birkeland, 1984; Bullock \& Thompson, 1985 e Fedoroff \& Eswaran, 1985).

Segundo Perecin \& Campos (1976), a formação de uma Terra Roxa Estruturada a partir de um Latossolo Roxo pode ter ocorrido pela deposição de argila iluviada sobre a fábrica intertéxtica dando origem à fábrica porfirosquélica e ao aparecimento de fissuras. Concluíram que a argila iluviada, que atualmente está se depositando nas fissuras, provem de períodos de iluviação recente.

Lepsch et al. (1977) explicaram a formação de horizontes argílicos nas encostas íngremes adjacentes a Oxissolos pelo movimento lateral da água nos horizontes superficiais provocando uma redução, por curto espaço de tempo, dos óxidos de ferro hidratados provocando a remoção destes. Isto provoca rompimento nas ligações argila-ferro, liberando as argilas para serem transportadas e acumuladas em posições mais baixas, formando um horizonte argílico. Processo semelhante foi descrito por Queiroz Neto et al. (1981) para explicar a passagem lateral de horizontes Bw para horizontes Bt numa vertente em Marília (SP) e demonstrado micromorfológicamente por Castro (1989).

A transição entre solos ferralíticos para solos beges da região de Casamance no Senegal foi explicado por Chauvel \& Pedro (1978) como sendo devido a um fenômeno de ultradessecação provocado por regimes climáticos muito contrastantes que provoca o rompimento das ligações ferro-argila dos solos ferralíticos e uma posterior redistribuição do material, iluviação e obstrução dos poros para formar solos com estrutura compacta e maciça ("sols beige").

Numa topossequência em Itatiba (SP), Moniz \& Buol (1982) e Moniz et al. (1982) observaram que a relação Oxissolo-Ultissolo é controlada por mudanças na morfologia do relevo da área. À medida que a vertente se forma, devido ao aprofundamento do nível de base, o processo de fluxo lateral de água começa a funcionar. Como conseqüência, os solos perto da superficie sofrem compressão devido a ciclos alternados de umedecimento com saturação e dessecação o que vai resultar na formação de horizonte argílico com estrutura em 
blocos e densidade do solo maior. Para explicar a ocorrência de minerais menos intemperizados nas posições mais baixas da vertente, sugeriram a ocorrência de um processo de ressilicatização formando minerais de argila, contrabalanceando o processo de alitização.

A formação de horizonte $\mathrm{Bt}$ a partir do horizonte Bw é explicada por Fedoroff \& Eswaran (1985) como sendo resultado da translocação e deposição de argila em horizontes Bw. O processo começaria com uma compactação dos agregados do horizonte Bw, posteriormente a argila se depositaria na forma de argilans cobrindo estes agregados e preenchendo os poros de empilhamento. Esta compactação começa nos horizontes superficiais; depois progressivamente os agregados aumentam de tamanho, se fundem, se aprofundam e depois, consequentemente, a abundância de argilans aumenta.

Miklós $(1992 ; 1995)$ verificou que a transformação da estrutura microagregada, característica dos Latossolos, em estrutura poliédrica, característica dos horizontes argílicos, foi devida às alternâncias dessecação/retração e umedecimento/expansão que ocorreram em climas mais secos e contrastantes que os atuais provocando a compactação da estrutura microagregada. Posteriormente teria ocorrido a iluviação da argila, preenchendo os espaços porosos, seguida de uma fissuração provocada pela retração do material. Atualmente, segundo este autor, está acontecendo o desaparecimento do horizonte com estrutura poliédrica formando uma zona de transição com presença de agregados poliédricos e microagregados, ora poliédricos ora ovais. Estes últimos são formados pela intensa fissuração atual, formando cavidades irregulares, e pela intensa bioturbação, respectivamente.

Vidal Torrado \& Lepsch (1993) estudando uma topossequência sobre migmatitos em Mococa (SP) concluíram que os responsáveis pela transição $\mathrm{Bw} / \mathrm{Bt}$ foram os processos de adensamento e argiluviação. Estes dois processos foram ocasionados pela ação do fluxo lateral de soluções favorecendo a formação de agregados maiores e mais estáveis e a translocação e deposição de argilas. $O$ processo de argiluviação também foi favorecido pelo material de origem menos intemperizado no sopé. 
Em uma área no distrito de Tupi, Piracicaba (SP), Vidal-Torrado (1994) e VidalTorrado et al. (1995) observaram que a transição entre horizontes Bw e Bt foram propiciadas por uma mudança na dinâmica da água na vertente devido ao entalhamento da superficie geomórfica mais antiga. Isto provocou o aparecimento do fluxo lateral da água favorecendo o adensamento subsuperficial do Latossolo e consequentemente a mudança dos fluxos de circulação interna, que se faz de forma concentrada nas paredes dos agregados poliédricos, favorecendo novamente o transporte de argilas. A argiluviação foi um processo importante, obstruindo parcialmente a porosidade, provocando o hidromorfismo temporário e com isso a remoção de ferro e favorecendo o transporte da argila. A argiluviação também promoveu a ligação entre microagregados favorecendo a formação de agregados maiores.

Até agora foram citados trabalhos que estudaram a transição entre horizonte $\mathrm{Bw}$ para horizontes Bt. Existem vários trabalhos que estudam a transição Bt para $B w$.

Stoops (1968) explicou que a transição entre um Ultissolo e um Oxissolo envolve a degradação do horizonte argílico. Segundo Fedoroff \& Eswaran (1985), a parte superior do horizonte argílico perde a maior parte dos argilans, sendo alguns deles retidos em algumas áreas ou incorporados ao fundo matricial. Para eles, os processos de pedoturbação são responsáveis pela homogeneização do material do solo e isto pode ser verificado pela presença de pedotúbulos, agrotúbulos e biotúbulos na parte superior do horizonte argílico.

Pedro et al. (1976) mostraram a formação de uma Terra Roxa Legítima (Latossolo Roxo) a partir de uma Terra Roxa Estruturada. Eles dividiram o processo em cinco estágios: no primeiro, parte-se de um plasma formando uma massa contínua; no segundo, processos de expansão e contração ocorrem e desenvolvem uma rede de fissuras permitindo a circulação de água e ar; no terceiro, essa circulação de água elimina progressivamente cátions e ao mesmo tempo os elementos de transição presentes nos óxidos de ferro, resultando numa evolução das formas de ferro nas proximidades das fissuras que provoca uma grande opacidade das periferias; no quarto, a evolução continua no cortex e a microestrutura se transforma dando origem progressivamente a uma porosidade "contornada"; finalmente esta 
transformação ocorre em todo o material formando a estrutura microagregada. Forma-se assim uma estrutura em "pó de café" que corresponde ao LR que é muito evoluído.

Em uma sequêencia TRE --> LR em Ribeirão Preto (SP) Carvalho et al. (1982) concluíram que na TRE, localizada na meia encosta, a formação de microagregados era inibida pela abundância de sílica e bases contida neste perfil. A sílica e bases chegavam por iluviação recente de material intemperizado de basalto. No LR os microagregados estão caracterizados pela abundância de separações plásmicas. Os autores interpretaram que a formação destes foi resultado da tensão e pressão provocadas pela expansão e contração do material.

\section{5. "Stonelines" e descontinuidade litológica}

"Stonelines" ou linhas de pedras são concentrações de fragmentos de rocha ou de minerais encontrados na rocha mais grosseiros formando uma linha podendo ser com espessura de um seixo ou maior, que geralmente se encontra sobre o material intemperizado sendo coberta por materiais que podem ser sedimentos de espessura variável (Ruhe, 1959).

Existem várias hipóteses sobre a origem das "stonelines", podendo citar: a origem alóctone, a origem autóctone, a origem biológica e a origem residual por alteração geoquímica.

A origem alóctone refere-se à formação da "stoneline" durante o desenvolvimento de uma superficie jovem, a água que provoca a erosão remove as partículas pequenas provocando uma concentração de cascalho na superficie. Esta camada de cascalho, que foi transportada, pode sofrer um recobrimento por depósitos derivados das partes mais elevadas da paisagem que são transportados até o pedimento e depositados ali ou no vale (Ruhe, 1959).

Seguindo a mesma linha de pensamento, Tricart (1959), Bigarella \& Mousinho (1965), Ab'saber (1966), Ranzani et al. (1972) interpretaram as "stonelines" como sendo de 
composição litológica variável e oriundas de transporte a curta distância, consideradas verdadeiros depósitos de encosta anteriores aos depósitos argilo-arenosos que os recobrem. Estas stonelines foram caracterizadas por todos estes autores como paleopavimentos detríticos oriundos de fases secas que afetaram ao Brasil.

Penteado \& Ranzani (1973) também admitiram a existência de coluvios superpostos separados por "stonelines", os quais teriam evoluido para horizontes distintos (Bt, Bw, etc.), explicando assim a superposição de horizontes pedológicos superpostos como paleohorizontes.

Em trabalhos mais recentes, Lichte $(1990,1991)$ estudando as "stonelines" no sudeste do Brasil chegou à conclusão que elas se formaram como resultado da distribuição de cascalho na superfície, por processos de erosão, em condições onde práticamente não existia vegetação. Estes resultados estão de acordo com as idéias apresentadas pelos pesquisadores acima citados.

As hipóteses autoctonistas referem-se à formação das "stonelines" "in situ". Em 1988 Lecomte ${ }^{3}$, citado por Lichte (1991), explicou que a concentração "in situ" das "stonelines" era resultado da migração descendente de fragmentos grosseiros em uma camada impregnada com água, enfatizou que este tipo de "stoneline" é formada em condições tropicais úmidas.

Lucas et al. (1990) explicaram que a formação de uma "stoneline" "in situ" depende da interação de três fatores: da abundância de fragmentos grosseiros passíveis de serem acumulados (esta abundância pode depender da intensidade de formação de nódulos ou da presença de fragmentos resistentes ao intemperismo no saprólito); do processo de dissolução dos fragmentos grosseiros na stoneline; do processo de concentração espacial dos fragmentos grosseiros num nível determinado do solo. Na maioria dos casos este nível se refere ao

${ }^{3}$ LECOMTE, P. Stoneline profiles: importance in geochemical exploration. Journal of Geochemical Exploration, 30(1):35-61. 1988. 
desaparecimento da estrutura lítica e ao desenvolvimento da pedoturbação, a concentração sendo provavelmente devido a uma dissolução preferencial da matriz fina, assim como a micro-movimentos mecânicos.

Numa topossequência sobre basalto em Ribeirão Preto (SP), Carvalho et al. (1982) encontraram duas "stonelines" em posições distintas. O primeiro nível situado num depósito de talus sendo formada pelo acúmulo de blocos de basalto que provem do material de alteração onde eles estavam incluídos. O segundo nível é formado por concreções litorreliquiais e separam o material microagregado formado "in situ" do material transportado poroso situado acima da "stoneline".

O revolvimento causado pela mesofauna do solo provocando um remonte vertical é a explicação dada para a origem biológica das "stonelines". Dijkerman \& Miedema (1988) estudando uma catena em Sierra Leone verificaram que a "stoneline" formada embaixo de um material sem cascalho poderia ser explicada como uma concentração de material grosseiro deixada pelos cupins após extrair o material fino. Johnson (1990), numa área da Califórnia, observou que a mesofauna que atuava naquela área provocava uma ciclagem ascendente das partículas menores, as quais elas podiam transportar, deixando as partículas mais grosseiras. Estas últimas se acumulavam gradualmente a uma certa profundidade formando a "stoneline". Numa cobertura pedológica em Botucatu (SP), Miklós (1992, 1993) explicou que a formação da "stoneline" ocorria por um único mecanismo, consistindo este no remonte vertical dos materiais profundos realizado principalmente pelas formigas e cupins.

McFarlane \& Pollard (1989), estudando uma topossequência em Malawi, observaram que a origem da "stoneline" era genética, essencialmente residual resultando da intemperização de veios de quartzito presentes no material de origem. Onde não ocorriam estes veios eram simplesmente uma frente de dissolução irregular e convoluta. Vidal-Torrado (1989) observou o mesmo fenômeno numa topossequência em Mococa (SP), onde algumas "stonelines" eram formadas "in situ" como produtos de alteração do migmatito correspondendo os fragmentos de quartzo a veios de quartzito da, rocha. Estas "stonelines" 
formadas a partir de veios de quartzo poderiam ser também enquadradas nas de origem autóctone.

Algumas hipóteses de formação de "stonelines" explicam a existência de descontinuidades litológicas. Estas descontinuidades litológicas implicam na comparação do solum com o material de origem. $\mathrm{O}$ uso de minerais estáveis, assim como os elementos que os compõem providenciam uma forma de estabelecer a uniformidade de um depósito e de avaliar quantitativamente as mudanças que ocorreram durante o desenvolvimento do solo. A quantidade de zircônio, titânio e quartzo no solo são utilizados por vários pesquisadores para estabelecer o grau de uniformidade dos depósitos (Marshall, 1940; Marshall \& Haseman, 1942; |Chapman \& Horn, 1968; Fost \& Rust, 1968; Sudom \& St. Arnaud, 1971; Drees \& Wilding, 1973;|[Demattê, 1978; Santos et al., 1986; Rabenhorst \& Wilding, 1986; Luz et al., 1992; Stolt et al., 1993). | 


\section{MATERIAL E MÉTODOS}

\subsection{Localização e caracterização do meio físico}

A área de estudo encontra-se no Campus da USP em Piracicaba, centro-leste do Estado de São Paulo, acima do Trópico de Capricórnio. Situa-se entre as coordenadas $22^{\circ} 44^{\prime}$ de latitude sul e $47^{\circ} 33^{\prime}$ de longitude oeste (Figure 1 e

Figura 2).

Geologicamente situa-se num topo de interflúvio formado pelo Rio Piracicaba sobre depósitos neocenozóicos predominantemente arenosos correlatos da formação Rio Claro, que se assentam sobre os sedimentos do permiano inferior da formação Iratí. Tal estratigrafia é interrompida no local de estudo por uma intrusão de rochas básicas hipabissais (diabásio) na forma de um grande sill, relacionado com a formação Serra Geral, do jurássico/cretáceo que, após fases erosivas do passado, acabou por ser exposto pelo entalhamento do vale, sendo o material de origem de parte dos solos estudados.

Geomorfologicamente a área situa-se na Zona do Médio Tietê da província da Depressão Periférica. Predominam nesta zona relevos de colinas amplas e colinas médias (IPT, 1981). Segundo Penteado (1968), o quadro morfológico mais característico é o de amplitude de horizontes e suavidade de formas, formando colinas de topo aplainado entre 550 e $650 \mathrm{~m}$, levemente convexas, divisoras de vales largos, rematados em fundo chato de planícies aluviais medíocres. Apesar de dominarem os sedimentos paleózóicos, ocorrem áreas superficiais descontínuas de corpos intrusivos magmáticos, geralmente na forma de sills e diques de diabásio que desempenham papel importante na topografia. 


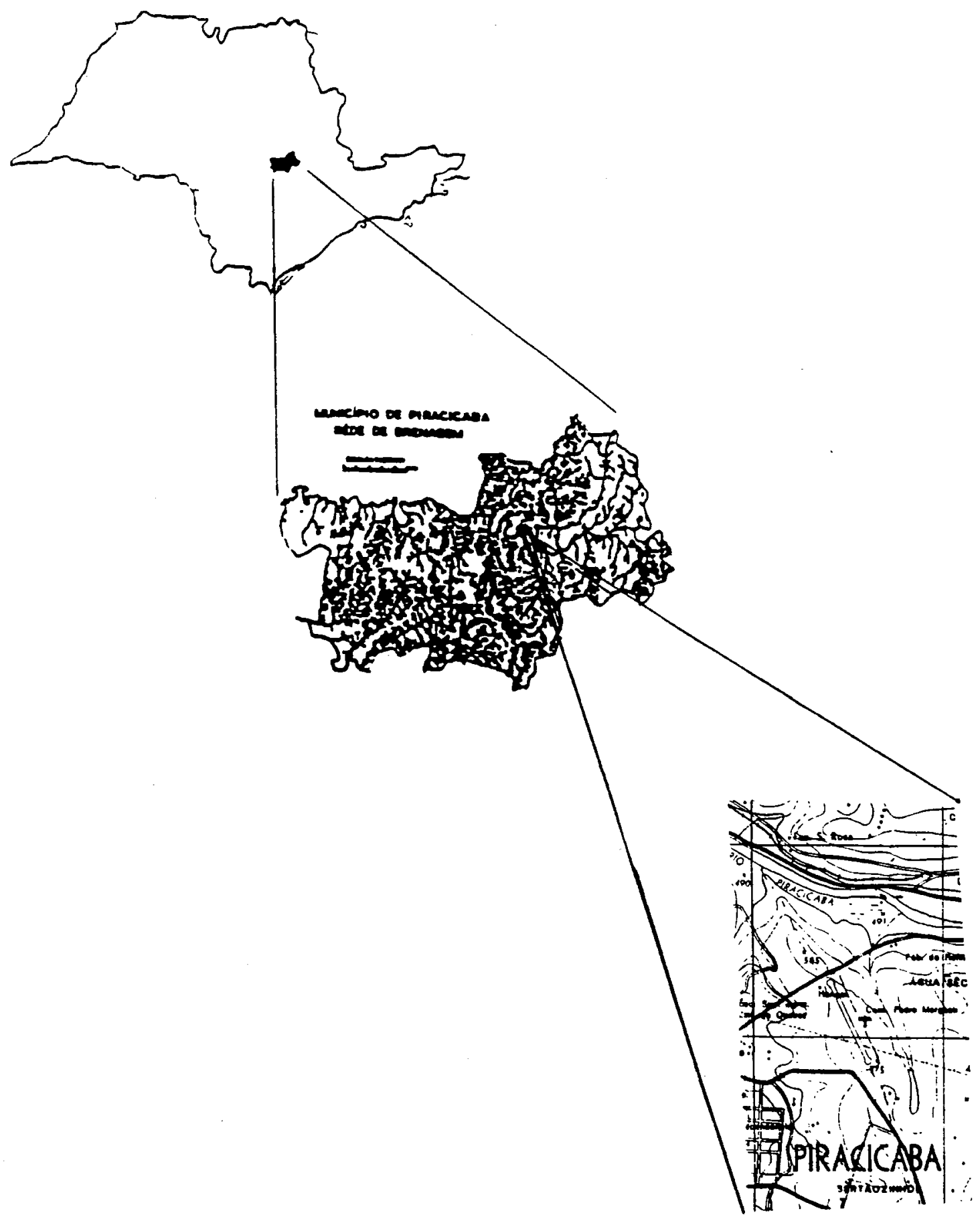

Figura 1: Localização da área estudada. 


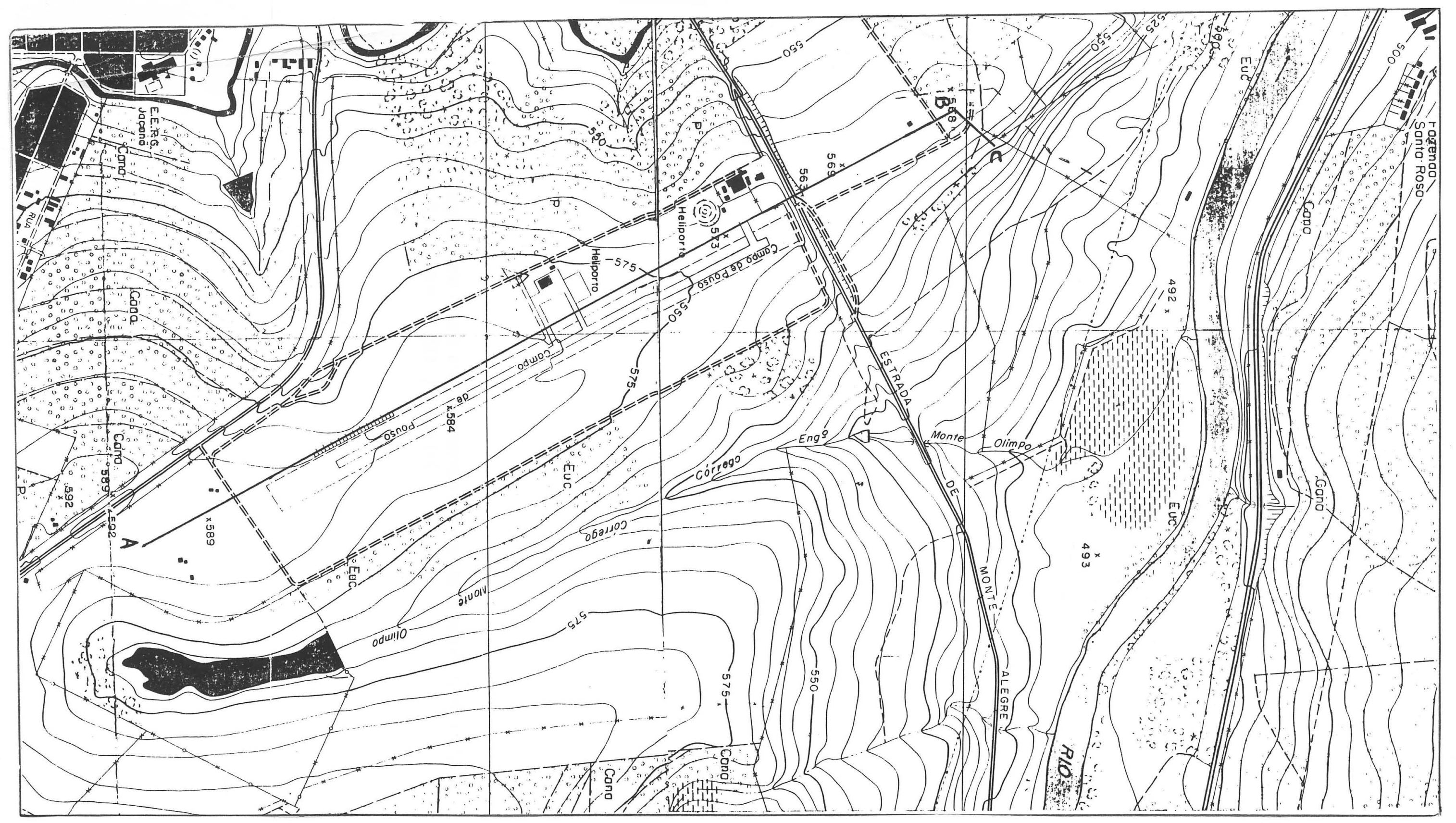




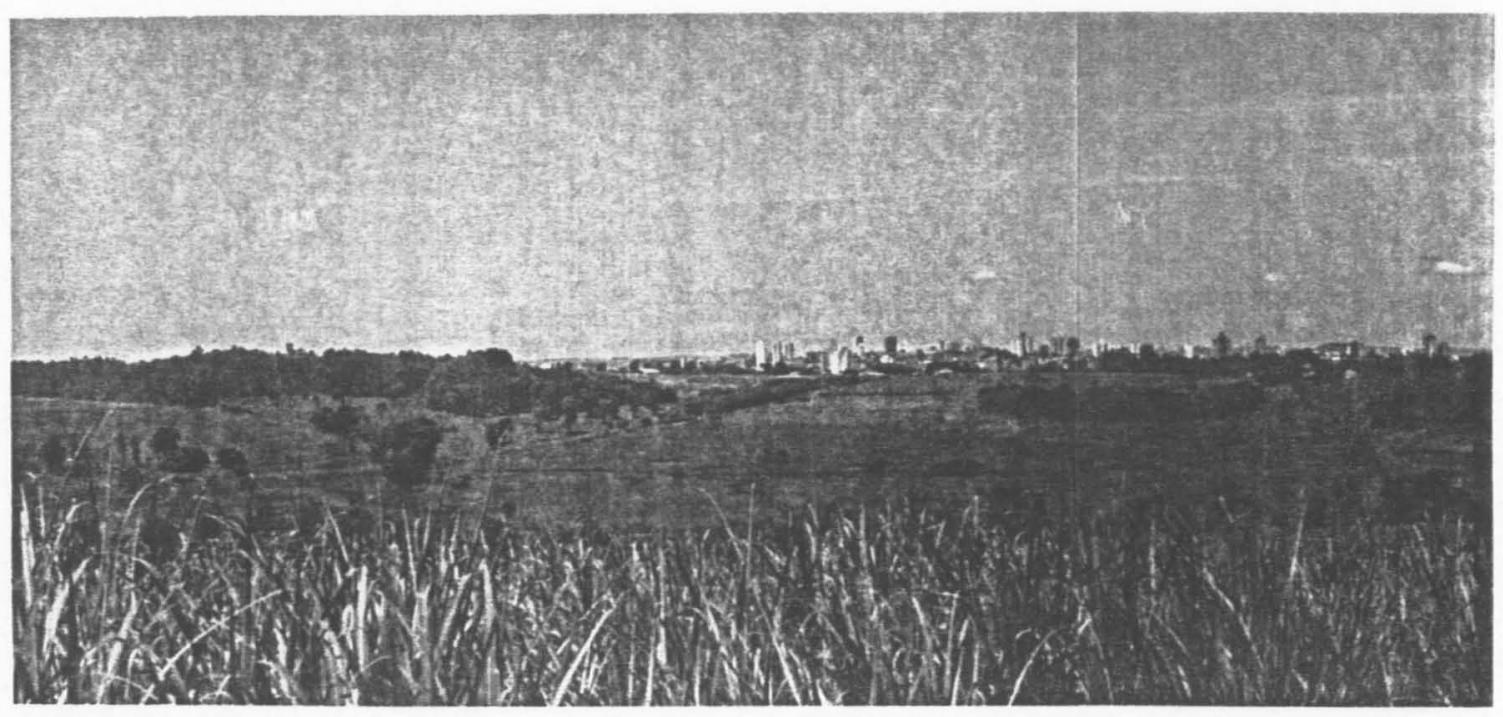

Figura 3: Fotografia da seqüência estudada. 


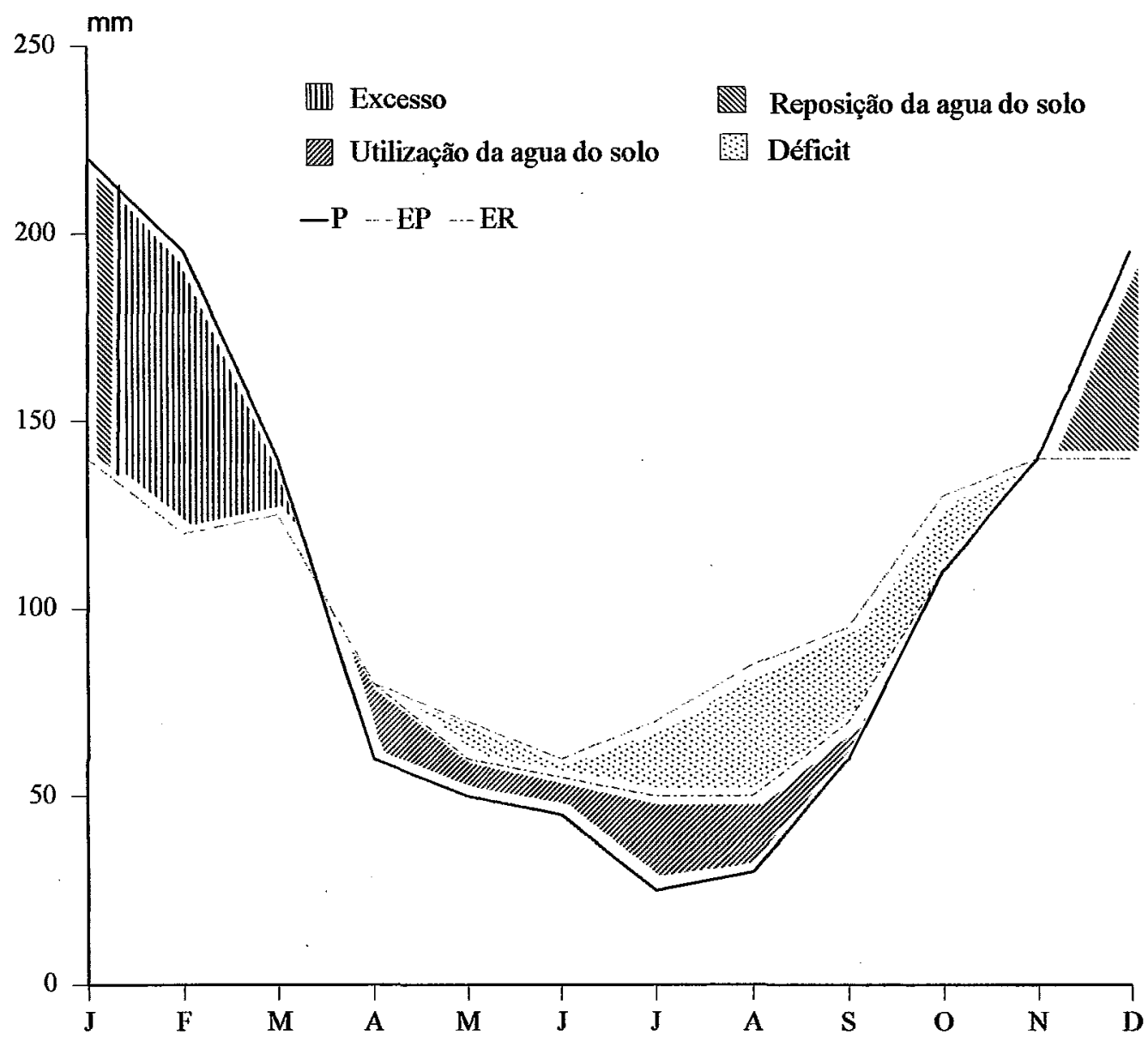

Figura 4: Balanço hídrico da região de Piracicaba.

O clima da região de Piracicaba, é classificado no sistema Koppen como Cwa, isto é mesotérmico úmido subtropical de inverno seco, em que a temperatura do mês mais frio é inferior a $18^{\circ} \mathrm{C}$ é a do mês mais quente ultrapassa os $22^{\circ} \mathrm{C}$ (Comissão de Solos, 1960). O regime térmico dos solos é hipertérmico (Oliveira et al., 1976). O total de precipitação para os meses de inverno é de $101 \mathrm{~mm}$. Janeiro é o mês mais úmido, com uma média de $217 \mathrm{~mm}$, sendo a média geral para os meses mais úmidos (dezembro, janeiro, fevereiro) de 619mm (Figura 4).

A cobertura vegetal natural da área perteneceu ao subtipo floresta latifoliada tropical (Ranzani et al., 1966). 


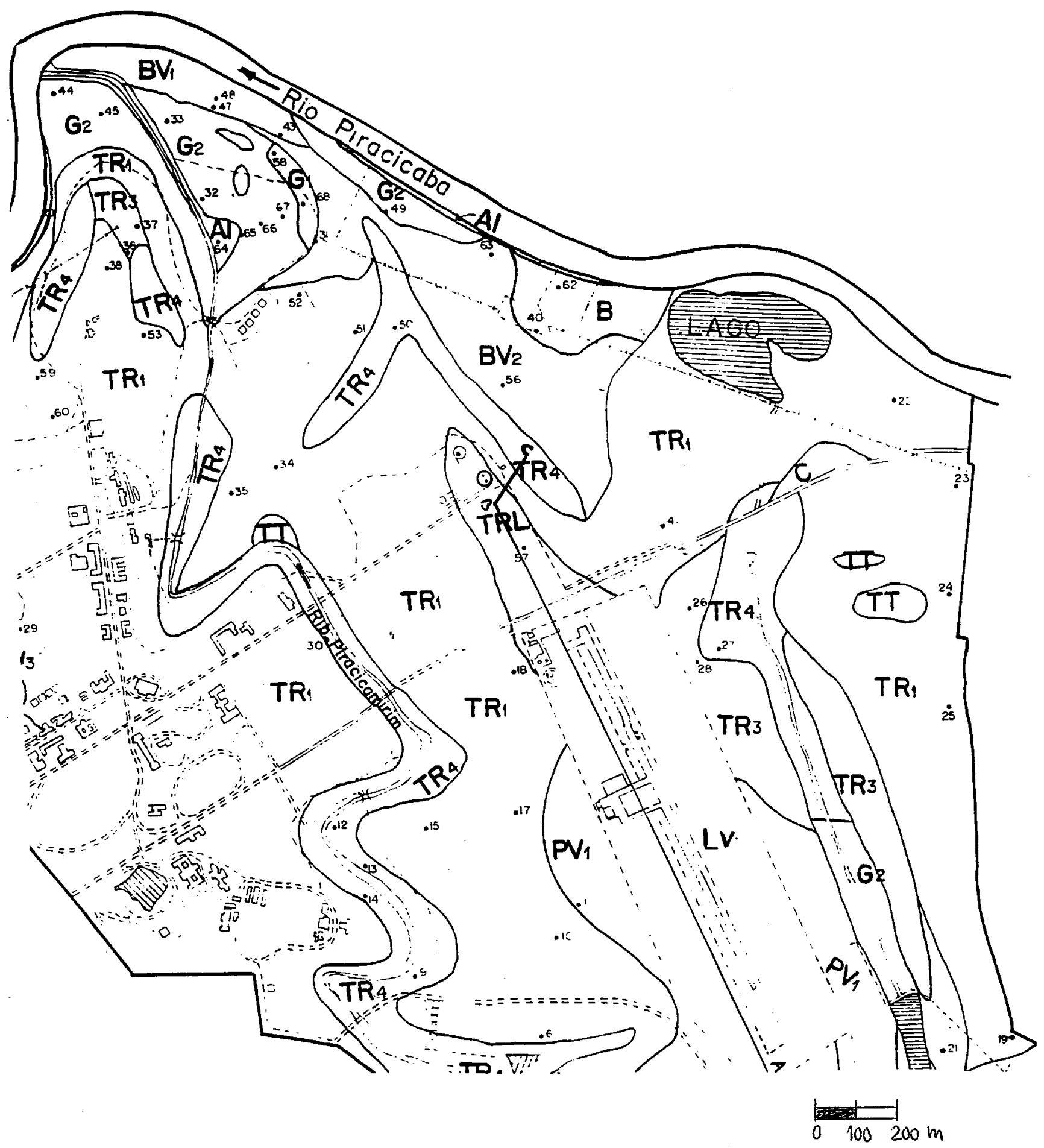

Figura 5: Mapa pedológico semi-detalhado (Vidal-Torrado et al. ${ }^{4}$, 1993) mostrando a posição da sequência estudada (Corte $\mathrm{A}, \mathrm{B}, \mathrm{C}$ ). 


\subsection{Solos}

O mapa de solos da área estudada (Figura 5) foi realizado por Vidal-Torrado et al. ${ }^{4}$ (1993), e apresenta os seguintes solos:

LV $\rightarrow$ Latossolo Vermelho-Amarelo Álico, Amoderado, textura média (Typic Hapludox).

TRL $\rightarrow$ Terra Roxa Estruturada Latossólica Eutrófica, A moderado, textura argilosa/muito argilosa (Kandiudalfic Eutrudox).

TR1 $\rightarrow$ Terra Roxa Estruturada Eutrófica, A moderado, textura argilosa/muito argilosa (Kandiudalfic Eutrudox).

TR2 $\rightarrow$ Terra Roxa Estruturada Distrófica, A moderado, textura argilosa/muito argilosa (Rhodic Kandiudox).

TR3 $\rightarrow$ Terra Roxa Estruturada Eutrófica Puoco Profunda, A moderado, textura argilosa/muito argilosa (Kandiudalfic Eutrudox).

TR4 $\rightarrow$ Associação de Terra Roxa Estruturada Eutrófica pouco profunda, A moderado ou chernozêmico, textura argilosa, fase pedregosa (Rhodic Kandiudalf) + Terra Roxa Estruturada Eutrófica, A moderado, textura argilosa (Rhodic Kandiudalf) + Cambissolo Eutrófico, A moderado ou chernozêmico, Tb, textura argilosa, substrato diabásio (Typic Eutrochrept).

PV1 $\rightarrow$ Podzólico Vermelho-Amarelo Distrófico, Tb, A moderado, textura média/média (Typic Paleudult).

BV1 $\rightarrow$ Brunizem Avermelhado, textura argilosa, substrato sedimentos pelíticos carbonáticos ou não da formação Irati (Typic Argiudoll).

BV2 $\rightarrow$ Associação Brunizem Avermelhado, textura argilosa, substrato diabásio (Typic Argiudoll) + Terra Roxa Estruturada intermediária para Brunizem Avermelhado

${ }^{4}$ VIDAL-TORRADO, P.; SPAROVEK, G.; COOPER, M; OLIVEIRA, M.C. de \& VLAS BOAS DO PRADO, G. Mapa pedológico detalhado do Campus "Luiz de Queiroz".Escola Superior de Agricultura "Luiz de Queiroz". 1993.Não publicado. 
(Typic Hapludoll) + Terra Roxa Estruturada Eutrófica, textura argilosa/muito argilosa (Rhodic Kandiudalf).

$\mathrm{B} \rightarrow$ Associação de Brunizem textura argilosa, substrato diabásio (Typic Argiudoll) + Brunizem Vértico, substrato diabáiso (Vertic Argiudoll) + Vertissolo (Typic Chromudert) com inclusões de Plintossolo Vértico (Plintaquept).

$\mathrm{Al} \rightarrow$ Solo Aluvial Eutrófico, Tb, textura média/arenosa (Typic Udifluvent).

G1 $\rightarrow$ Gleissolo Eutrófico, A chernozêmico, textura média a argilosa (Humic Haplaquept).

G2 $\rightarrow$ Gleissolo Eutrófico, A moderado, textura argilosa/argilosa ou média/média a argilosa (Typic Haplaquept) com inclusões de solos vérticos (Vertic Haplaquept).

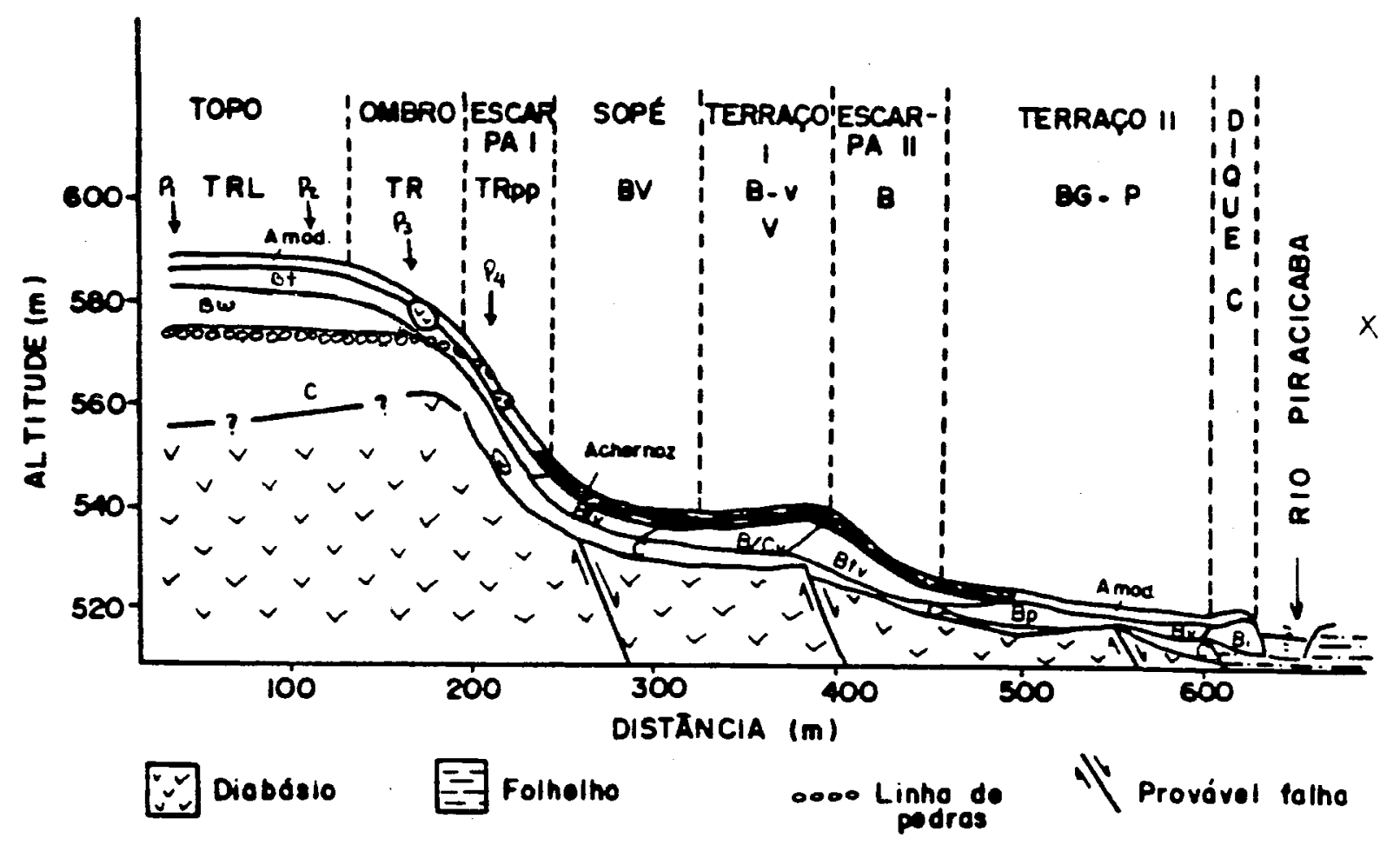

Figura 6: Perfil topográfico semi-esquemático mostrando os segmentos da vertente e respectivas classes de solos, geologia e pricipais horizontes (Bw: $\mathrm{B}$ latossólico; $\mathrm{Bt}$ $\mathrm{Tb}$ : $\mathrm{B}$ textural com argilas de atividade baixa; Btv: $\mathrm{B}$ textural com argilas de atividade alta e com algumas propriedades vérticas; $\mathrm{B} / \mathrm{Cv}$ : horizonte vértico; $\mathrm{Bp}$ Ta: Horizonte plintico com argilas de atividade alta; $\mathrm{Bi}$ : $\mathrm{B}$ incipiente com argilas de atividade baixa) 


\subsection{Levantamento e caracterização morfológica}

\subsubsection{Análise estrutural da topossequência}

Para o detalhamento maior da vertente foi realizado um estudo bidimensional da configuração lateral dos diferentes horizontes seguindo metodologia proposta por Boulet et al. (1982) e BouleT (1988). Comparou-se a morfologia dos horizontes dentro da transeção e a partir destas observações, desenhou-se em papel milimetrado, toda a sequência vertical $\mathrm{e}$ lateral dos horizontes, permitindo a visualização desta em corte longitudinal desde o topo até o dique marginal (Figura 6).

\subsubsection{Estabelecimento dos segmentos da vertente}

Foram reconhecidos e delimitados os segmentos topo, ombro superior, ombro inferior, sopé, primeiro terraço (ou patamar estrutural), ombro do terraço, segundo terraço e dique marginal. Os critérios utilizados para tal distinção entre segmentos estão descritos em Hall (1983) e Conacher \& Dalrymple (1977).

\subsubsection{Estabelecimento dos locais de amostragem}

Observando-se o mapa planialtimétrico da área na escala 1:10000 foi escolhida a vertente em estudo devido a que nela estão bem caracterizados todos os segmentos descritos por Hall (1983) e Conacher \& Dalrymple (1977). A grande variabilidade de solos e as transições bem definidas entre horizontes condicionou a escolha da transeção estudada. Após a delimitação dos segmentos procedeu-se à identificação, no topo, dos locais a serem amostrados. 


\subsection{Amostragem dos solos}

Conhecidos os segmentos da vertente e visando estudar a transição existente entre os horizontes Bw e Bt assim como a formação do horizonte Bw, foram abertas 3 trincheiras no topo, ombro e começo da meia encosta onde estas feições se apresentavam mais caracterizadas. Foi estudado também um barranco da estrada que atravessa a área de estudo, localizado no topo da sequência. No topo, um número variável de tradagens profundas foram realizadas para o estudo da origem da "stoneline" e da uniformidade do material seguindo a metodologia da análise estrutural proposta por Boulet et al. (1982).

Nas trincheiras e no barranco foram feitas descrições morfológicas seguindo as normas do Manual de Descrição e Coleta de Solos no Campo (Lemos \& Santos, 1984), coletadas amostras deformadas para análises granulométricas ${ }^{1 \%}$ de rotina, amostras indeformadas para a determinação da densidade do solo e na parte superior da topossequência foram coletadas amostras indeformadas e orientadas para análise micromorfológica.

Nas tradagens profundas foram coletadas amostras a profundidades regulares distanciadas $50 \mathrm{~cm}$ entre elas. Nestas amostras foram determinadas a cor e a textura, e realizadas análises químicas e granulométricas de rotina.

\subsection{Análise das amostras de solo}

\subsubsection{Análise granulométrica das amostras de solo}

As análises granulométricas das amostras coletadas em trincheiras e tradagens foram feitas nos laboratórios do Departamento de Ciência do Solo da ESALQ/USP. Após agitação horizontal por 16 horas, foi feita a granulometria da TFSA (terra fina seca ao ar)

pelo método do densímetro, utilizando-se como dispersante solução contendo hidróxido de sódio e hexametafosfato de sódio (Camargo et al:; 1986). 


\subsubsection{Análise mineralógica da fração argila}

Selecionaram-se algumas amostras do horizonte $\mathrm{B}$, representativas do topo e ombro da vertente, para a determinação da composição mineralógica da fração argila. Seguindo a metodologia proposta por Jackson (1969), as amostras foram preparadas e tratadas. Após a eliminação da matéria orgânica e dos óxidos de $\mathrm{Fe}$, a fração argila foi separada por sifonagem. Subamostras foram saturadas com $\mathrm{K}^{+}$ou com $\mathrm{Mg}^{2+}$, e foram irradiadas com raios $X$ através de difratômetro Rigaku, com tubo de cobre e filtro de niquel, no intervalo $2 \theta$ de 3 a $32^{\circ}$. As subamostras saturadas com $\mathrm{K}^{+}$foram irradiadas à temperatura ambiente, após aquecimento a 350 e $550^{\circ} \mathrm{C}$. As saturadas com $\mathrm{Mg}^{2+}$ foram irradiadas à temperatura ambiente em duas etapas, antes e após solvatação com etileno-glicol, respectivamente.

\subsubsection{Análise micromorfológica}

Após a descrição morfológica dos perfis, segundo Lemos \& Santos (1984), foram coletadas amostras indeformadas e orientadas dos principais horizontes e as transições entre estes. Estas amostras foram secas em estufa e depois impregnadas com resina poliester Polilyte e monômero de estireno, utilizando-se peróxido de metil-etil-cetona como catalizador para a polimerização do poliester final (in Castro, 1985). Após o endurecimento do material, procedeu-se ao corte, polimento e à montagem em lâminas de vidro com Araldite. $\mathrm{O}$ polimento final foi feito com pó de carborundum com granulometria cada vez mais fina, até obtenção de secções delgadas com cerca de 30 micrấ de espessura.

A análise micromorfológica foi feita em microscópio petrográfico Zeiss, segundo os critérios estabelecidos por Brewer (1976) e Bullock et al (1985). Fotomicrografias foram feitas em fotomicroscópio Zeiss do DIGEO-IPT. 


\subsubsection{Determinação do zircônio, titânio, ferro e quartzo.}

As amostras foram diluídas com ácido bórico na proporção de 1:4, e em seguida foram preparadas pastilhas de $2,50 \mathrm{~cm}$ de diâmetro, pressionando-se $500 \mathrm{mg}$ dessa mistura a $240 \mathrm{MPa}$ (três repetições /amostra).

Para a avaliação da concentração dos elementos $\mathrm{Ti}, \mathrm{Fe}$ e $\mathrm{Zr}$ foi utilizada a técnica de fluorescência de raios $X$ com dispersão de energia, utilizando o sistema Spectrace 5000, da marca Tractor, EUA, pertencente à Central Analítica do Instituto de Química da Unicamp. $\mathrm{Na}$ excitação das amostras foi utilizado um tubo de raios X com anodo de Rh (raios X Ka de $20,17 \mathrm{keV}, 83,17 \%$, e $\mathrm{Kb}$ de $22,78 \mathrm{keV}, 16,83 \%$ ) operando em $30 \mathrm{kV}$ e $70 \mathrm{~mA}$, com filtro de $50 \mathrm{~mm}$ de $\mathrm{Rh}$, e na deteç̧ão dos raios $\mathrm{X}$ um detector semicondutor de $\mathrm{Si}(\mathrm{Li})$, com 30 $\mathrm{mm} 2$ de área ativa, $3 \mathrm{~mm}$ de espessura, resolução de $152 \mathrm{eV}$ para os raios $\mathrm{X}$ de $5,9 \mathrm{keV}$ e janela de $12,7 \mathrm{~mm}$ de Be.

Os espectros de raios $\mathrm{X}$ foram obtidos por um tempo de 100 segundos ("live-time") e posteriormente interpretados com o auxílio do programa AXIL (Espen et al., 1977; Espen et al., 1991). A partir das taxas de contagem dos raios X Ka característicos dos elementos Ti (4,93 keV), $\mathrm{Fe}(7,06 \mathrm{keV})$ e $\mathrm{Zr}(15,75 \mathrm{keV})$, foram calculadas as concentrações destes elementos empregando-se amostras-padrão de composição similar (Jenkins \& De Vries, 1970), fornecidos pela Agência Internacional de Energia Atômica (Soil5/ IAEA e SL1/IAEA), Viena/Austria, e SA Bureau of Standard (SARM 2, SARM 3 e SARM 4), Pretoria/África do Sul.

Para a determinação de quartzo por difratometria de raio-X, método adaptado de Johnson \& Beavers (1959), foi preparada uma curva padrão a partir do material de solo a ser analisado. Para a preparação desta extrae-se das amostras de solo o quartzo. Ao material sem quartzo são misturados diferentes concentrações conhecidas de quartzo puro. A curva padrão é preparada misturando-se $4 \mathrm{~g}$ de solo (solo sem quartzo + quartzo) e $2 \mathrm{~g}$ de um padrão, neste caso NaF. De cada ponto da curva foram preparadas três lâminas vazadas que foram lidas em aparelho de raio- $X$, com filtro de níquel, tubo de cobre e angulo de $15^{\circ}$ a $40^{\circ} 2 \theta$. A altura dos 
picos principais de quartzo $(-3,34 \AA)$ e de $\mathrm{NaF}(-2,32 \AA)$ é medida e sua relação (h quartzo/h $\mathrm{NaF}$ ) é calculada. Uma equação de regressão é ajustada com os dados desta relação (Y) e com aqueles dos teores de quartzo conhecidos $(\mathrm{X})$.

As amostras de solo (TFSA) são secas e misturadas com o $\mathrm{NaF}$ na relação $4 \mathrm{~g}$ de solo : $2 \mathrm{~g} \mathrm{NaF}$. As lâminas vazadas com essas amostras foram preparadas e lidas em aparelho de raio-X semelhantemente à curva padrão. $\mathrm{O}$ teor de quartzo foi estimado determinando-se sua relação $\mathrm{h}$ quartzo/h $\mathrm{NaF}$ e interpolando-se na equação ajustada pela curva padrão. 


\section{RESULTADOS E DISCUSSÃo}

\subsection{Material de origem e evolução da paisagem}

A área de estudo apresenta no topo um depósito formado por sedimentos arenosos inconsolidados neocenozóicos provavelmente correlatos à formação Rio Claro (TQir). Este depósito de textura média, que resultaria de um primeiro evento deposicional, assenta-se sobre os sedimentos do permiano superior da formação Irati (Pi). Lado a lado e formando uma transição abrupta com os sedimentos arenosos, um segundo depósito neocenozóico composto por um material argiloso e vermelho assenta-se sobre parte da formação Irati (que se encontra mais elevado junto ao sill) e um sill de diabásio. Este depósito caracterizaria um segundo evento deposicional. Descendo na vertente para o ombro e os terraços, o diabásio passa a ser o material de origem dos solos.

A formação superficial localizada no topo, aqui tratada como um depósito neocenozóico correlato à formação Rio Claro, assenta-se diretamente sobre a formação Irati (Pi) como pode-se observar num barranco da rodovia "Luiz de Queiroz" no km . A centenas de metros deste local, dentro do campus "Luiz de Queiroz", foi observado, na mesma cota, a presença da formação Corumbatai $(\mathrm{Pc})$. A ocorrência das formações Corumbatai e Irati na mesma cota, poderia ser explicada por uma reativação de antigas falhas normais que provocaram o deslocamento vertical de blocos (Figura 7). 


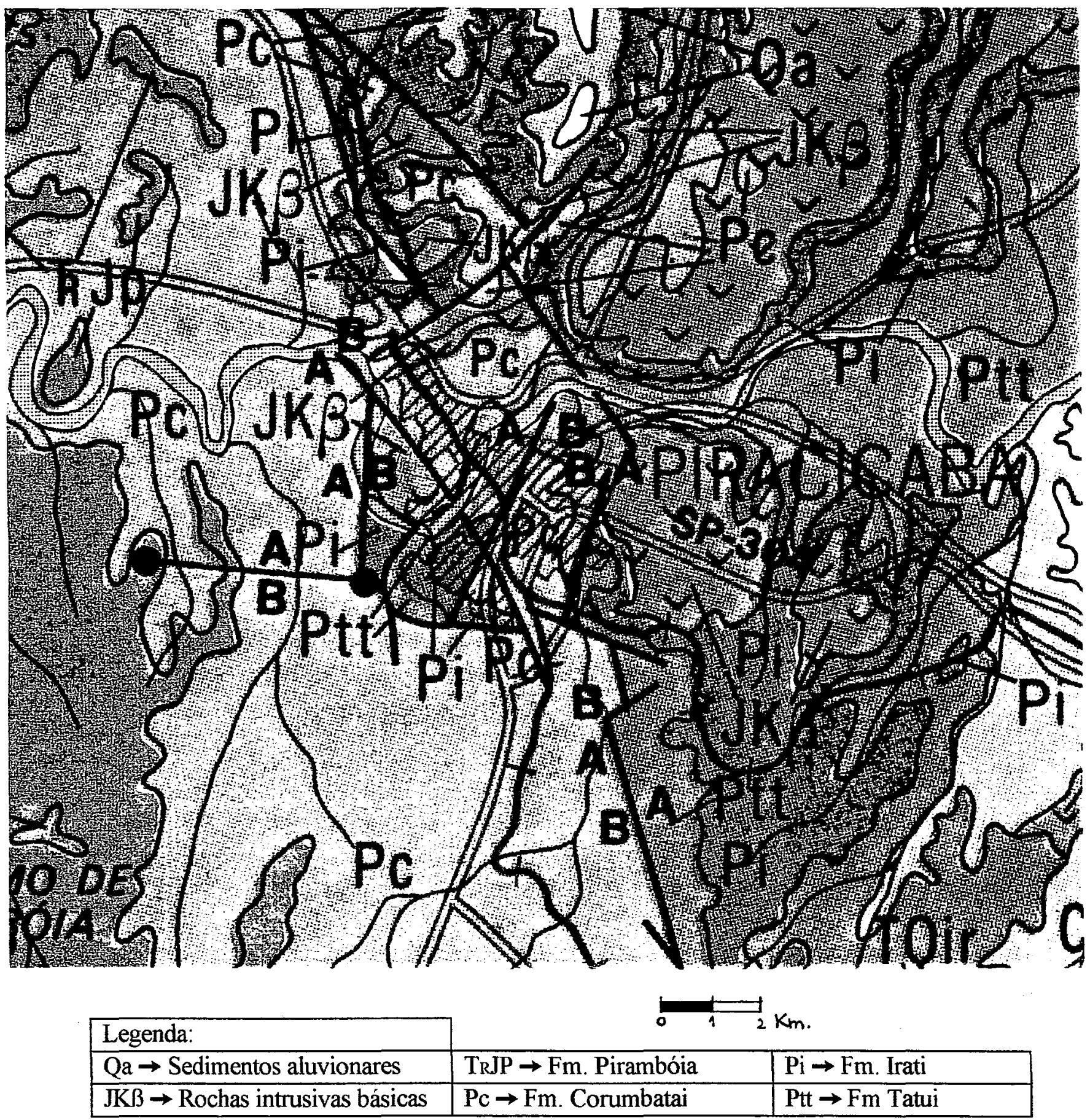

Figura 7: Mapa geológico de Piracicaba extraido de IPT (1981a), ampliado sem ajustes. 
Estes falhamentos poderiam ter sido originados no Permiano Superior durante o soerguimento da estrutura de Pitanga (Melo, 1995). No final do Jurássico ocorreu o evento denominado Reativacão Waldeniana, que se caracterizou por apresentar três fases. A primeira fase que se estende de fins do Jurássico ao Cretáceo Inferior, manifestou os processos magmáticos que produziram os grandes derrames basálticos da Formação Serra Gral (JKsg) que se alojaram nas falhas e fraturas formadas pelo fraturamento distensional sem dobramentos que ocorreu durante a elevação do Domo de Pitanga (Figura 9B), sendo esta a provável origem do sill de diabásio encontrado na área de estudo. A segunda fase que se desenvolveu entre o final do Cretáceo Inferior e o Eoceno, caracterizou-se pelo término do vulcanismo basáltico e atenuação dos processos tectônicos que o acompanharam. A terceira e última fase estendeu-se no restante do Cenozóico. Durante o Oligoceno, a no máximo Mioceno Inferior, ocorreu uma reativação da atividade tectônica em antigas falhas da Depressão Periférica (IPT, 1981a; Melo \& Ponçano, 1983). Acredita-se que estes falhamentos provocaram a movimentação de blocos do pacote estratigráfico provocando discordâncias estratigráficas a curta distância como aparece no mapa do IPT (1981a) (Figura 97).

$\mathrm{Na}$ mesma época em que estava acontecendo a reativação tectônica durante o Oligoceno, começou o processo de elaboração da Depressão Periférica, através de processos de morfogênese mecânica com pronunciada pediplanação, intercalados com fases de entalhes da drenagem (Melo \& Ponçano, 1983). Foi a partir deste momento que ocorreu o rebaixamento como consequência da erosão dos depósitos expondo assim, no final da elaboração da Depressão Periférica, o material mais resistente à erosão como os sills e diques de diabásio que conformaram as soleiras regionais citadas por Penteado (1968), Melo \& Ponçano (1983) e Melo (1995) (Figura 9 C). A partir deste momento se instala um longo período semi-árido (aproximadamente de 250.000anos), que se correlaciona com a fase glacial Danube no início do Pleistoceno, caracterizado por uma intensa morfogênese mecânica e uma pronunciada pedimentação. Este período teria provocado como resultado de forças de agradação e degradação o transporte de material arenoso de granulação fina que foi depositado nos barramentos litológicos formados pelas soleiras regionais configurando assim 
alveolos escalonados de textura média que poderiam-se correlacionar com a Formação Rio Claro (TQir) e o nível pedimentar Pd1, como foi relatado por Penteado (1968) e Melo (1995) (Figura 9 D). Este nível pedimentar Pd1, de material arenoso, corresponderia à superfície I da área de estudo descrita por Lobo (1984). Assim o sill de diabásio, encontrado na área de estudo, teria sido exposto durante a formação da Depressão Periférica e atuado como uma soleira regional barrando a passagem dos sedimentos arenosos finos transportados de uma posição a montante durante a fase semi-árida correspondente ao glacial Danube (Figura 9 E).

A nível regional observam-se vários topos quase planos de cotas variando entre 580 e $650 \mathrm{~m}$. Nestes encontram-se solos de textura média classificados como Latossolos Vermelhos Amarelos e Latossolos Vermelhos Escuros, junto a solos argilosos derivados de diabásio como os Latossolos Roxos e as Terras Roxas Estruturadas (

Figura 8). Estes topos encontram-se alinhados numa direção NNE-SSW entre os rios Capivari e Piracicaba. Este alinhamento se correlacionaria com a direção indicada por Penteado (1968) para as soleiras tectônicas desta região. Não foi constatada ao oeste destes topos a presença de solos de textura média, predominando nessa região os solos argilosos e muito argilosos. Estas evidências sugeririam que os topos, onde predominam os Latossolos Roxos e as Terras Roxas Estruturadas, conformariam uma longa soleira regional. Esta soleira teria atuado como uma barreira onde foram depositados, ao oeste desta, os materiais arenosos provavelmente retrabalhados e transportados de áreas mais elevadas onde afloram os sedimentos arenosos da formação Pirambóia (TrJp) (Figura 7).

Observações feitas no barranco da rodovia "Luiz de Queiroz" no km 45 e através de tradagens profundas, mostraram que na base do material de textura média no contato com a formação Irati observa-se a formação de uma "stoneline", que apresenta seixos arredondados de quartzito de tamanhos variando entre $1 \mathrm{~cm}$ e $8 \mathrm{~cm}$. A conformação da mesma, sua mineralogia e forma dos seixos, evidenciariam que sua origem seria alóctone havendo sido transportada e depositada em fases semi-áridas por processos de erosão 


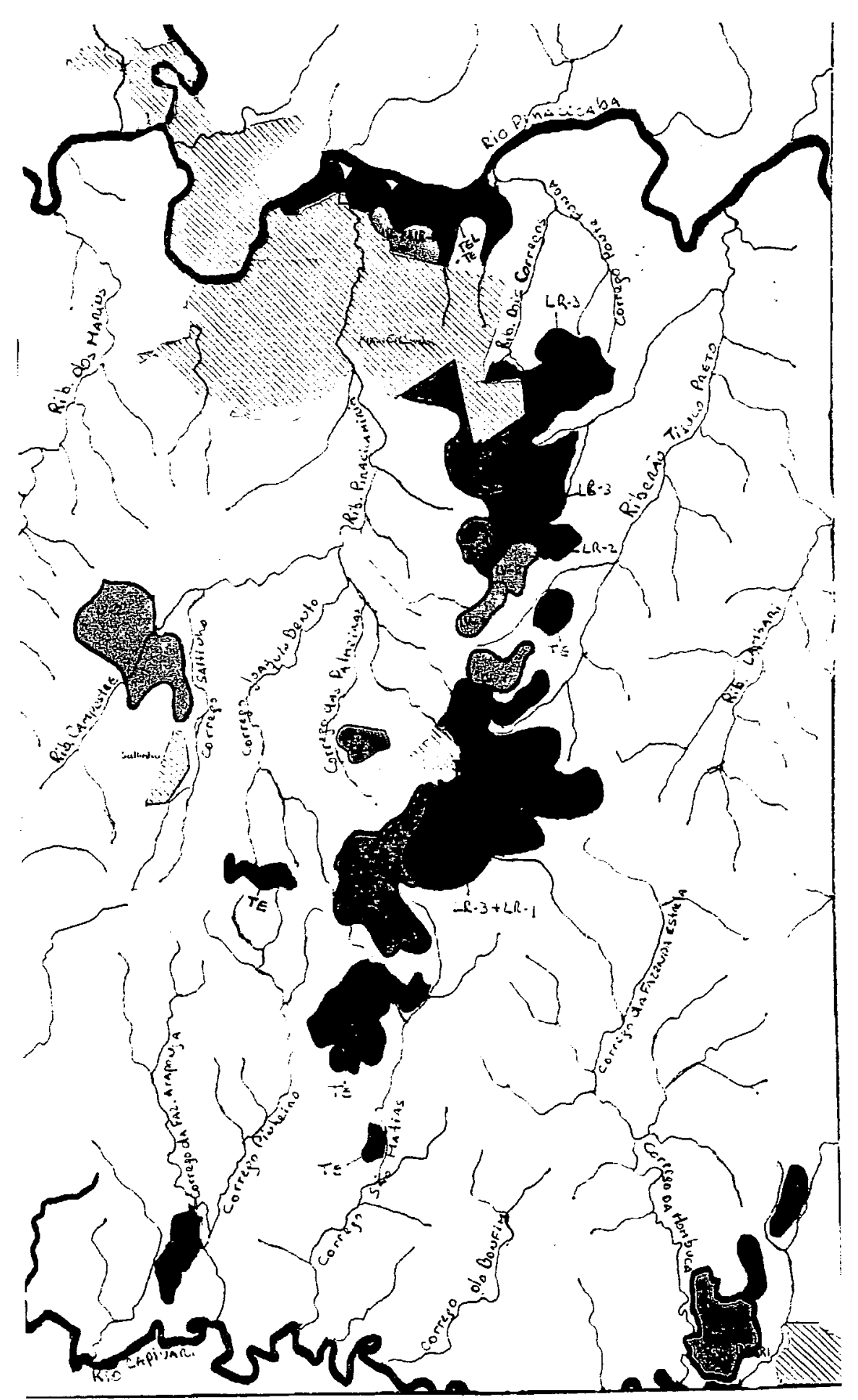

Figura 8: Manchas de solos originários de material básico (em roxo) que teriam formado parte de soleiras regionais e manchas de Latossolos de textura média (em amarelo $\mathrm{e}$ vermelho) que seriam depósitos barrados pelas soleiras. Fonte: Oliveira \& Prado (1989).

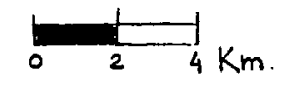


A)

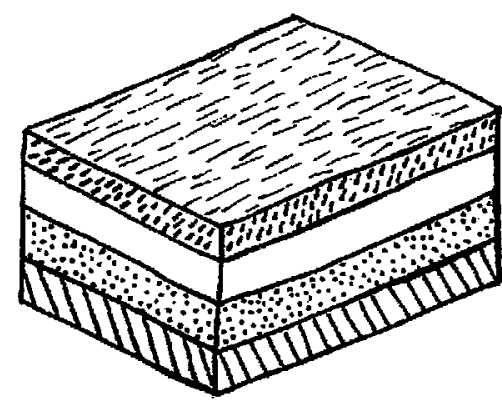

D)

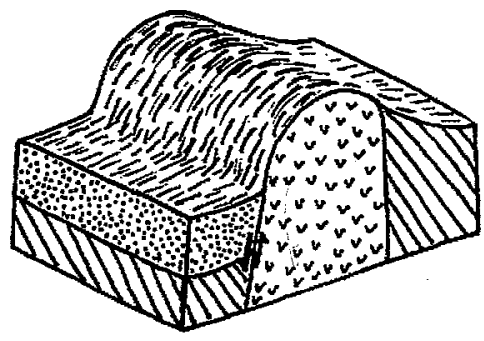

G)

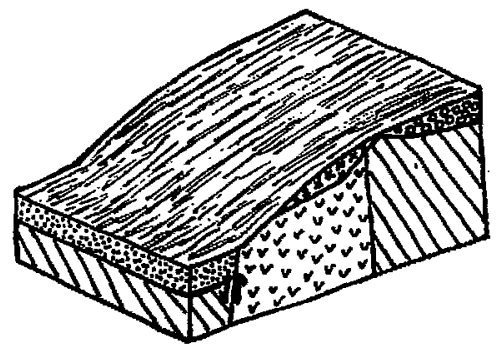

B)

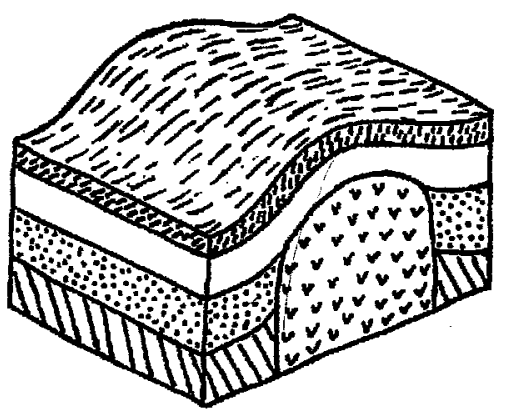

E)

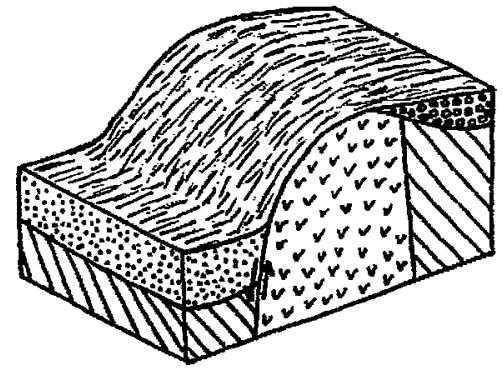

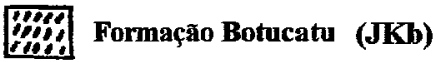

$\square$ Formação Pirambóia (TrJp)

Formaỹo Corumbatai (Pc)

MIV Formação Irati (Pi)

SYyg Sill de diabásio (JKsg)
C)

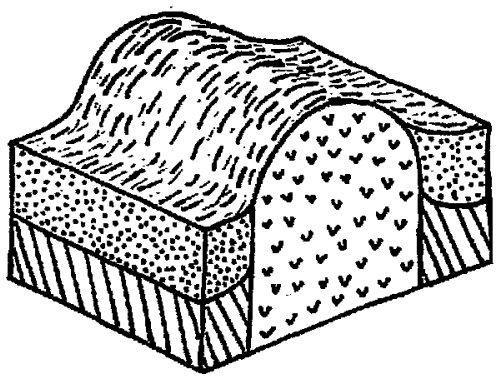

F)

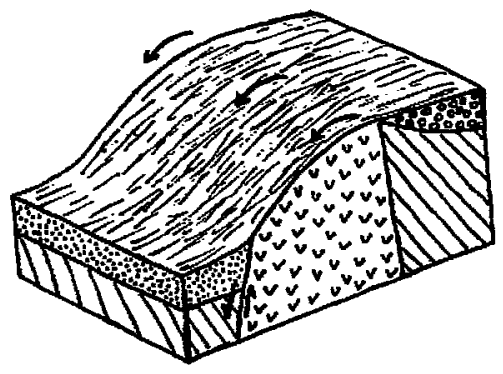

Depósito neo-cenozóico arenoso
curreluto com a $\mathbf{F m}$. Rio Clarv

XXF Depósito neo-cenozóico argilaso

Figura 9: Evolução da estratigrafia e do relevo da região da área estudada.A) Estratigrafia hipotética apresentada antes da intrusão do sill de diabásio (Jurássico-Triássico); B) Intrusão do sill em falhas formadas durante o Permiano Superior deformando os estratos sedimentares (Jurássico-Cretáceo); C) Escavação da Depressão Periférica expondo o sill de diabásio e formando as soleiras regionais (entre o Oligoceno e Plioceno); D) Reativação de antigos falhamentos durante a formação da Depressão Periférica soerguendo o sill de diabásio e a Formação Irati e rebaixando a Formação Corumbatai; E) Deposição de depósitos arenosos finos correlatos com a Formação Rio Claro nos barramentos litológicos durante fase semiárida correlacionada com o glacial Danube; F) Fase de pedimentação correlato com o glacial Gunz depositando, a jusante, material retrabalhado do diabasio e da Formação Rio Claro; G) Aspecto atual da estratigrafia da região aonde esta inserida a área de estudo. 
formando um paleopavimento detrítico, sendo recoberta depois por material mais fino(Tricart, 1959; Bigarella \& Mousinho, 1965; Ab'saber, 1966; Ranzani et al., 1972; Lichte, 1990, 1991). Isto mostra a existência de uma descontinuidade litológica entre este material e o material do Irati subjacente e reforça a idéia de que este material de textura média é de caráter deposicional.

Uma segunda "stoneline" foi observada no contato entre um material vermelho (matiz Munsell de 2,5YR) de textura argilosa e a alterita de diabásio, durante o estudo de um segundo barranco na estrada para Monte Alegre que atravessa a área de estudo. Esta é formada por seixos centimétricos de quartzito com alto grau de arredondamento sugerindo uma segunda descontinuidade litológica. A conformação lateral da mesma mostra que segue o contato entre estes dois materias desaparecendo quando ocorre a ruptura do relevo (Figura 6). A montante a "stoneline" encontra-se por alguns metros no contato entre o material vermelho e a alterita da formação Irati. Nesta parte da topossequência ela sofre uma ascensão gradual desaparecendo na superfície, sugerindo a deposição de um material coluvial na forma de bacia. O material que deu origem à formação desta "stoneline" seria de seixos que foram transportados junto com o material arenoso durante o primeiro evento de deposição e que se encontravam esparsos dentro deste sendo liberados e transportados posteriormente durante o processo de aplainamento.

A presença deste material de textura muito argilosa e cor vermelho escura depositado acima do sill de diabásio e de uma pequena porção da formação Irati, corresponderia a um segundo evento deposicional mais recente. Este evento corresponderia a uma fase de entalhamento do pediplano Pd1 e posterior pedimentação formando um nível pedimentar intermediário P2 (Bigarella \& Mousinho, 1965a) que corresponderia à superfície II descrita por Lobo (1984) (Figura 9 F). Melo \& Ponçano (1983) atribuem este evento ao período de semiaridez do glacial Gunz. $O$ entalhamento provocou a exposição do sill e de uma porção da formação Irati, a posterior pedimentação provocou o entulhamento do vale num processo de agradação, com a consequente elevação do nivel de base, dando origem a depósitos de terraços por sedimentação de lençóis de cascalho e sedimentos mais finos (Figura 9 G). $\mathrm{O}$ alto teor de ferro elementar(Figura 10) assim como a elevada quantidade de 
areia fina e média (Figura 11 e Figura 12) e quartzo deste material sugerem que o material fonte para estes sedimentos seria o própio sill de diabásio com contribuição da areia fina e média da formação Rio Claro.

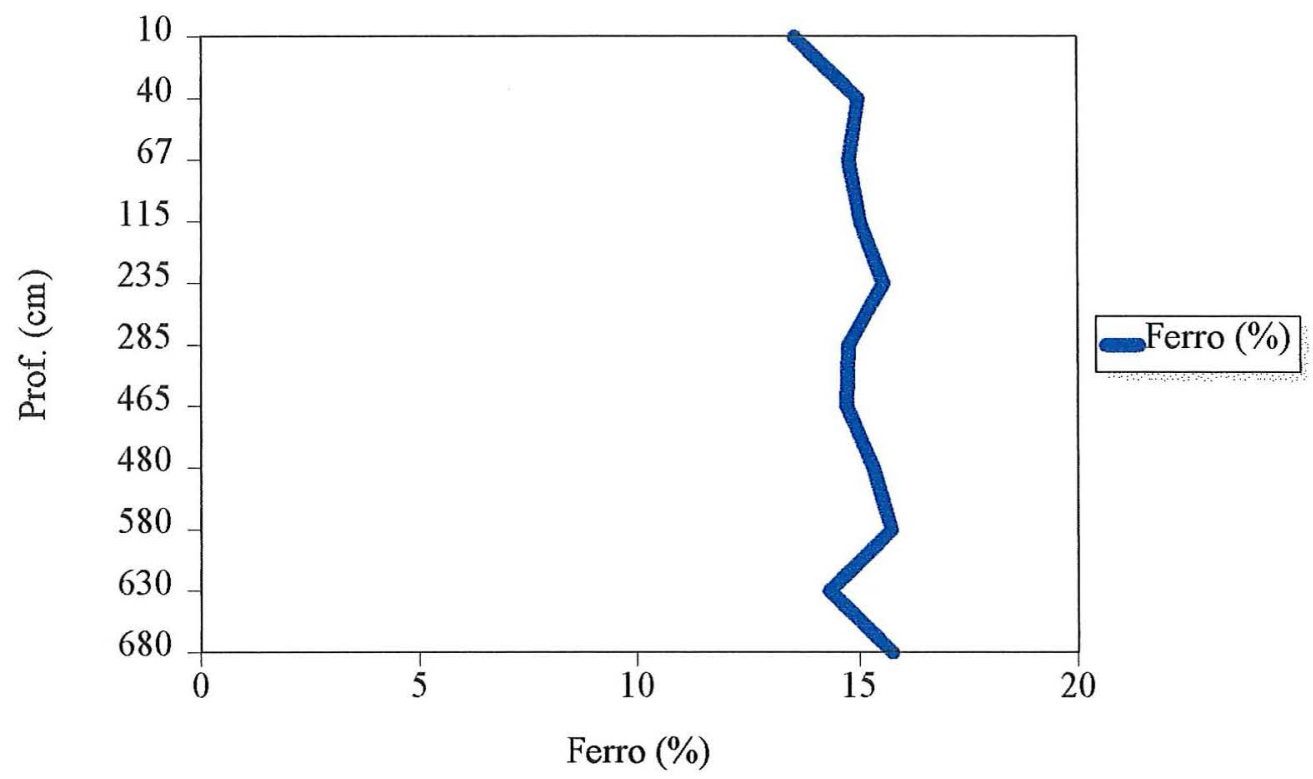

Barranco de estrada

Figura 10: Gráfico mostrando a variação no teor de ferro no perfil 1 (P1).

Este processo de transporte e deposição se confirmaria observando as Figura 11 e Figura 12 onde a medida que aumenta a distância do material fonte a quantidade de areia no solo diminue assim como aumenta a quantidade de areia fina em relação à areia grossa. Observações de campo também constataram que a espessura e o tamanho dos seixos da "stoneline" diminuiam neste sentido. Isto indicaria uma diminuição da energia cinética do fluxo de massa, que provocaria o depósito de materiais grosseiros perto da fonte e de materiais mais finos a distâncias maiores. 


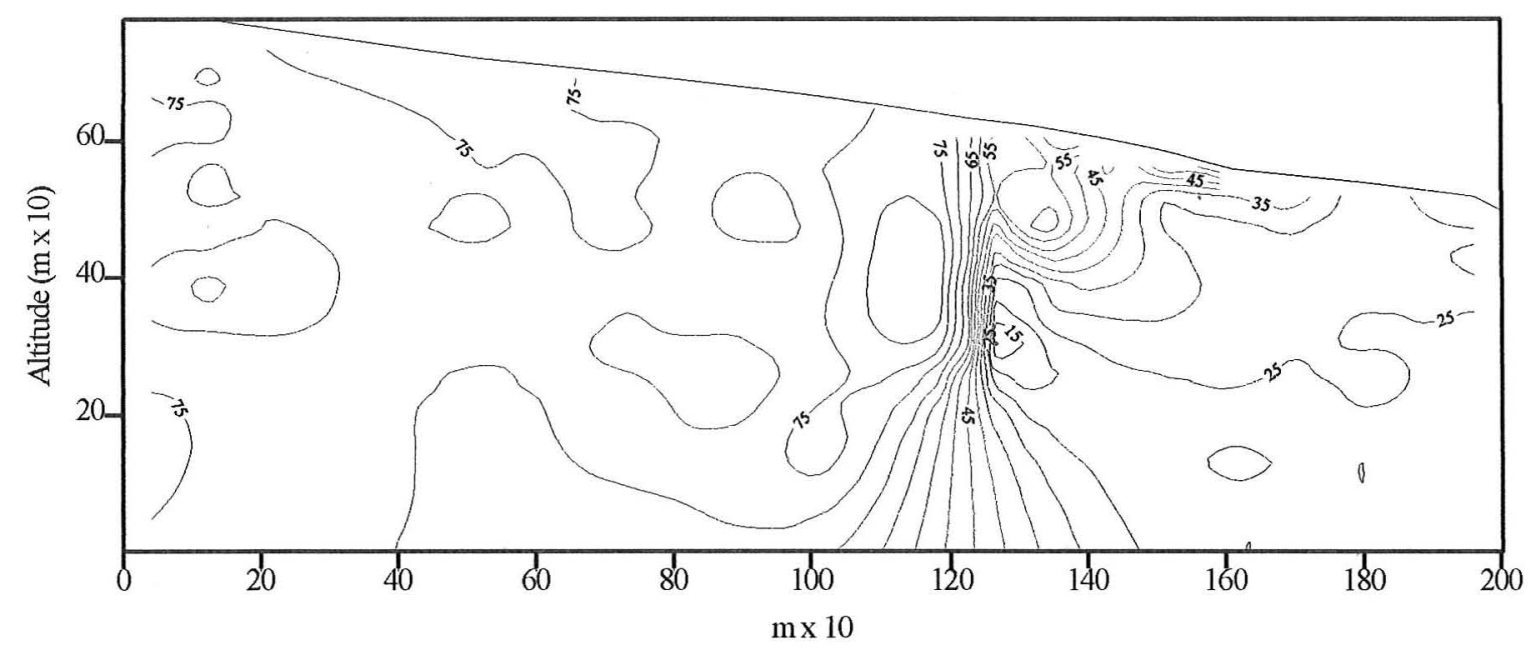

Figura 11: Gráfico de isolinhas mostrando a variação do teor de areia total no topo da topossequência

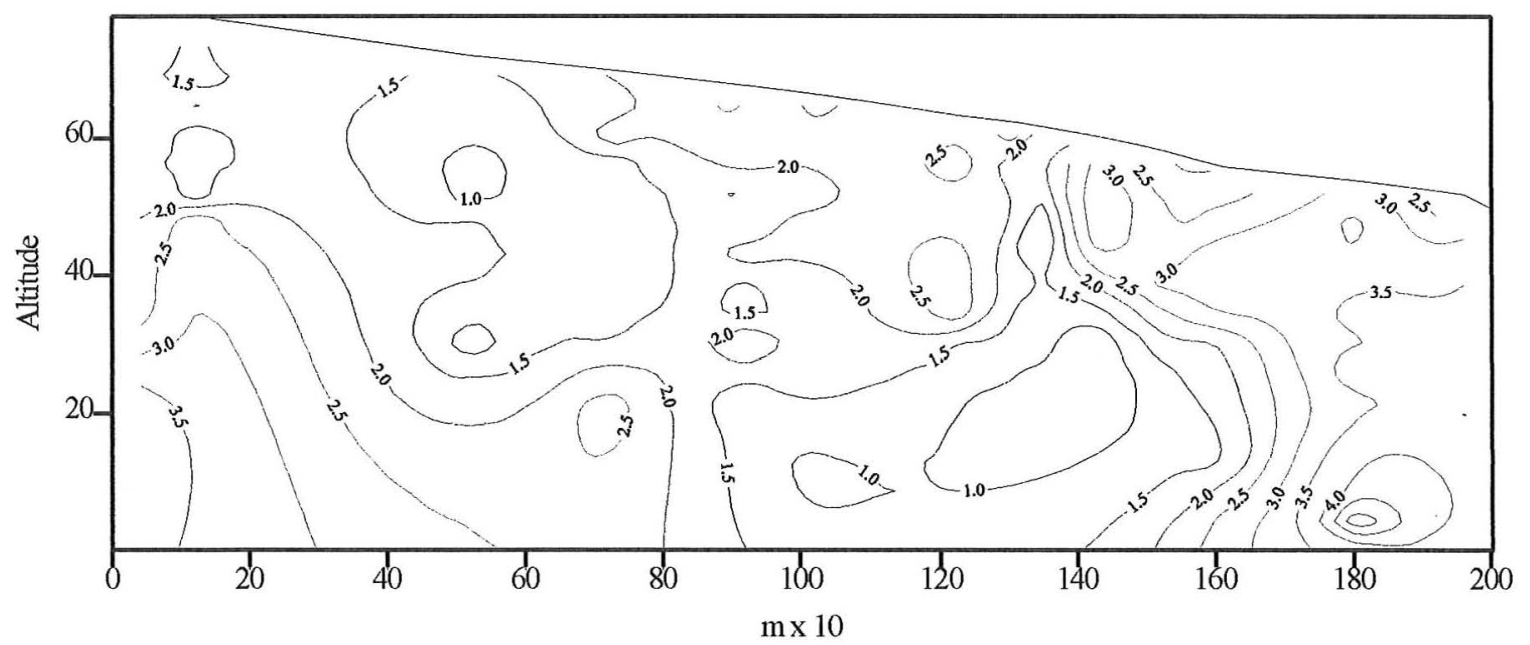

Figura 12: Gráfico de isolinhas mostrando a variação da relação areia fina/areia grossa no topo da topossequência 
Para reforçar a idéia de que a linha de pedra é um vestígio de um paleopedimento detrítico que foi recoberto por material que foi transportado e depositado, foram realizadas análises para a determinação de minerais e elementos estáveis (Quartzo, Zircônio e Titânio). A utilização destes elementos e minerais assim como algumas relações entre elas ( $\mathrm{Ti} / \mathrm{Zr}$ e $\mathrm{Zr} /$ Quartzo) foram utilizados por Sudom \& St. Arnaud (1971); Drees \& Wilding (1973); Demattê (1978); Santos et al. (1986); Rabenhorst \& Wilding (1986); Luz et al. (1992); Stolt et al. (1993), para verificar a existência de descontinuidades litológicas entre o material de origem e o solum. Os resultados mostraram que na determinação do teor de Zircônio elementar e Titânio elementar, em dois perfis, houve uma diferença significativa dos valores achados acima e embaixo da linha de pedra (Figura 1313). Uma variação de até $45 \%$ foi observado nos teores de $\mathrm{Zr}$ e Ti no perfil 1 (P1) e no perfil 3 (P3) esta variação chegava até 30\% (Apêndice 6). As relações Ti/Zr (Figura 14) e Zr/Quartzo (Figura 14) mostraram também uma diferença significante entre os dois materiais. Para o perfil 1 (P1) a diferença foi de $30 \%$ para a relação Ti/Zr e de até $50 \%$ para a relação $\mathrm{Zr} /$ Quartzo (Apêndice 6). $\mathrm{O}$ perfil 3 (P3) mostrou diferenças de até $20 \%$ na relação $\mathrm{Ti} / \mathrm{Zr}$, neste perfil não foi possível determinar a relação $\mathrm{Zr} /$ Quartzo. Estas diferenças encontradas ao longo dos perfis são em alguns casos superiores ou iguais às indicadas por Drees \& Wilding (1973) como indicadores de descontinuidades litológicas, mostrando que existem diferenças litológicas entre estes materiais. Estes dados devem ser interpretados com cuidado, já que não existem para as condições tropicais dados suficientes na literatura para especificar qual é a diferença suficiente para indicar uma descontinuidade litológica, sugerindo-se a utilização de outras análises para complementar o estudo de descontinuidades. Sabendo-se disto análises estatísticas da distribuição granulométrica das areias foram realizadas para confirmar a veracidade dos dados das análises de $\mathrm{Zr}$, Ti e quartzo. 


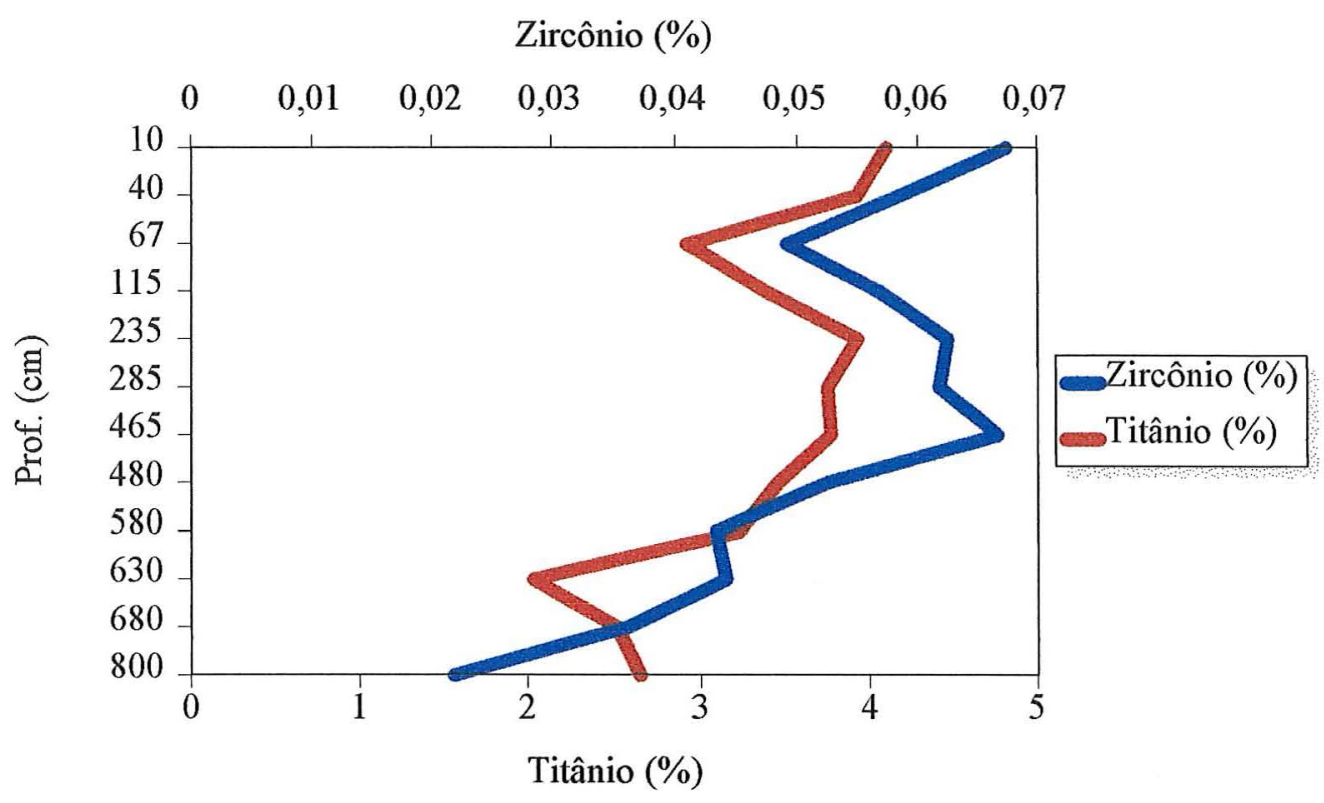

Perfil 1 (P1)

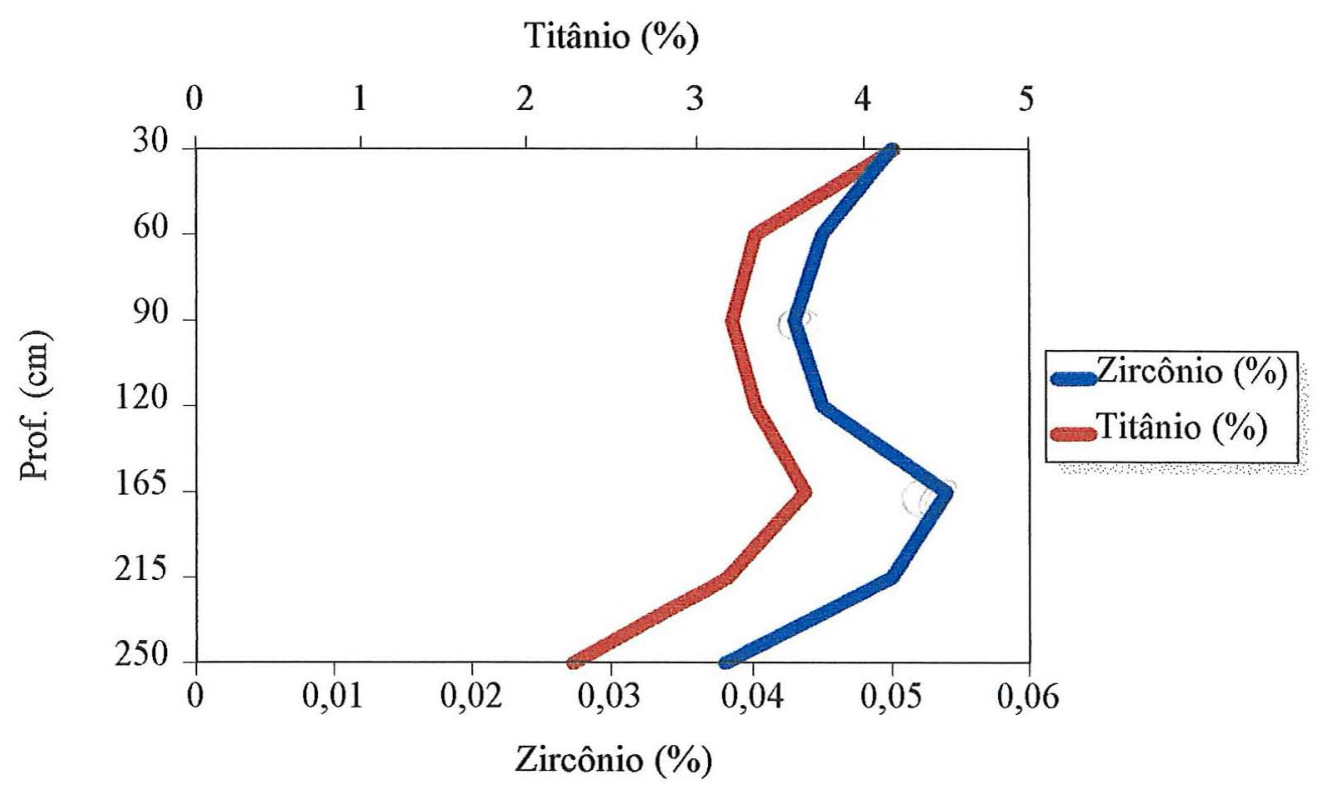

Perfil 3 (P3)

Figura 13: Gráficos mostrando a variação dos teores de Zr e Ti em dois perfis. 


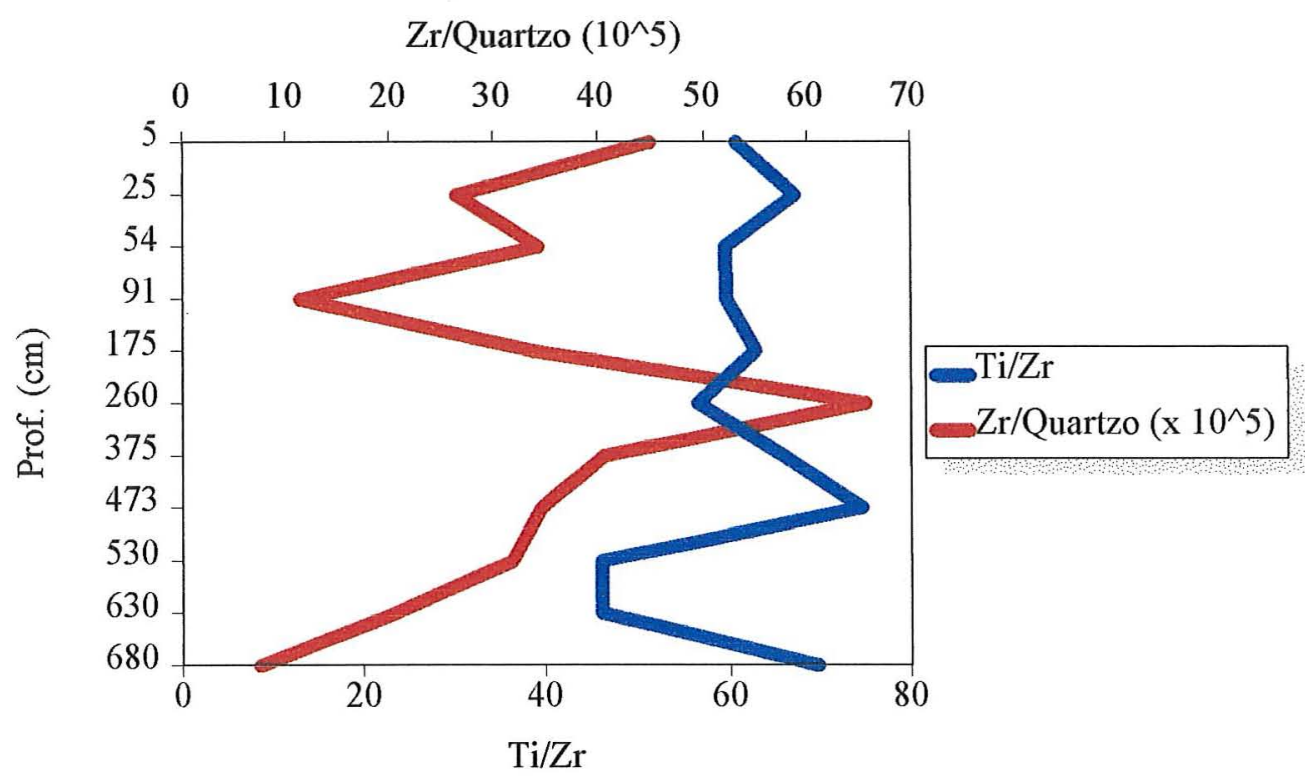

Perfil $1(\mathrm{P} 1)$

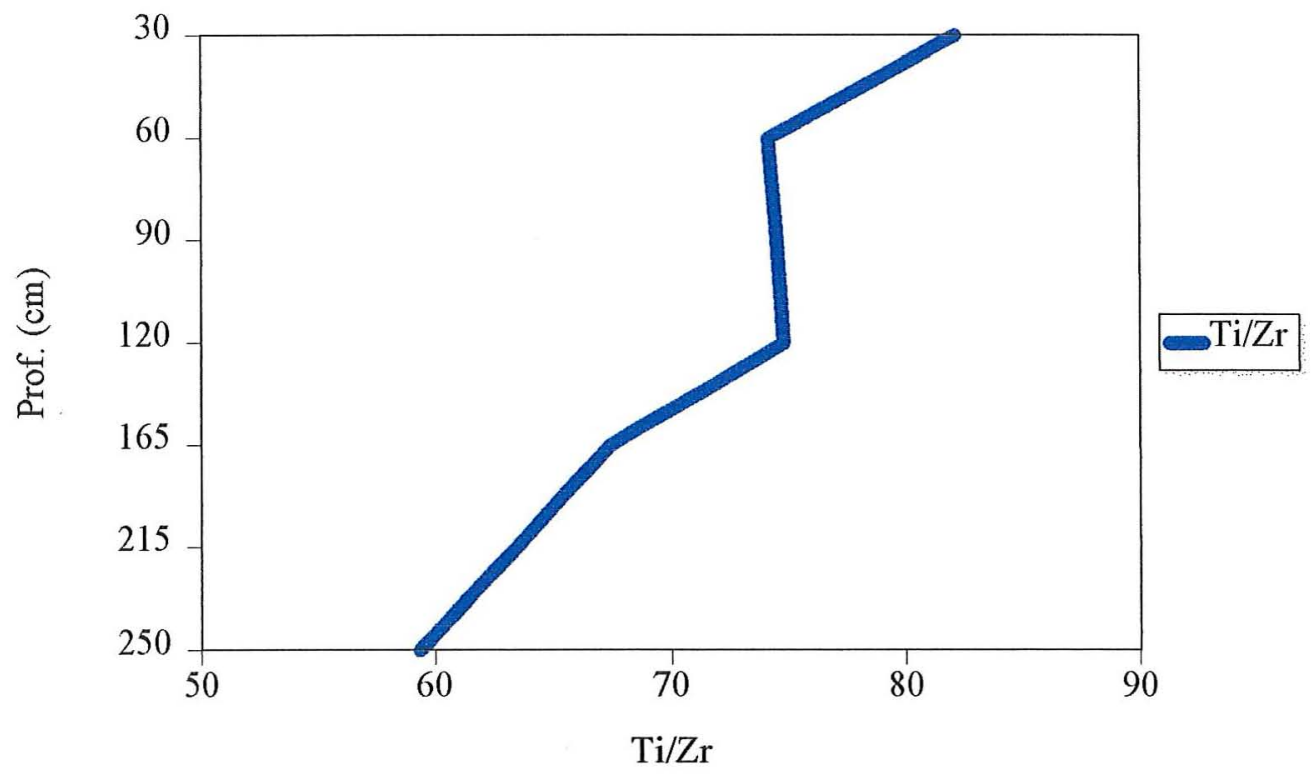

Perfil 3 (P3)

Figura 14: Gráfico mostrando a variação das relações Ti/Zr e Zr/Quartzo 
A análise da distribuição granulométrica dos sedimentos utilizando índices e parâmetros estatísticos possibilita estabelecer comparações precisas entre sedimentos e/ou camadas de solos, podendo assim inferir a natureza dos microambientes de deposição e possíveis descontinuidades litológicas (Suguio, 1973; Van Lier \& Vidal-Torrado, 1992). A metodologia baseia-se na idéia de que materiais sedimentares distintos possuem distribuições diferentes da fração areia. Diversos trabalhos de gênese de solos tem empregado estas técnicas de quantificação, como os de Vidal-Torrado (1994); Coelho et al. (1994) e Teramoto (1995). Para este estudo foram realizadas tradagens profundas ao longo do topo até uma profundidade de $8 \mathrm{~m}$ coletando-se amostras a cada $50 \mathrm{~cm}$. Por meio de análises granulométricas de rotina das amostras determinaram-se cinco frações de areia. Estas foram analisadas estatisticamente utilizando-se o programa "PHI" de Van Lier \& Vidal-Torrado (1992). Teramoto (1995) cita que a utilização de cinco frações somente, representa uma limitação a esta metodologia, mas que obteve resultados satisfatórios no seu estudo.

A análise estatística das areias do material de textura média (primeira tradagem TP3) mostra que não existe nenhuma mudança de distribuição até a profundidade amostrada (Figura 1515) (Apêndice 2), deve-se adicionar que a limitação imposta pelo comprimento do trado não permitiu a amostragem abaixo da "stoneline". A observação dos histogramas, mostra a predominância da areia fina e da areia média na distribuição das areias. A média de tamanho de partículas varia de 2,0 a $2,35 \phi$. O grau de seleção, que é medido pelo desvio padrão, indicou para este solo um grau moderadamente bem selecionado para todas as profundidades amostradas. A análise do grau de assimetria mostrou para a maioria das profundidades amostradas a dominância de uma assimetria gráfica aproximadamente simétrica, duas profundidades $(170-220 \mathrm{~cm}$ e $270-320 \mathrm{~cm})$ mostraram uma assimetria positiva. A curtose da distribuição das areias não mostrou variações acentuadas, predominando o caráter mesocúrtico em todo o perfil observando-se uma tendência a leptocúrtico nas amostras de superficie e na mais profunda. A análise dos histogramas, da média gráfica, do desvio padrão, assimetria e curtose revelam o predomínio de areia fina bem selecionada com uma distribuição simétrica, estes dados sugerem que este material foi transportado e depositado conforme sugeriu Suguio (1973). 

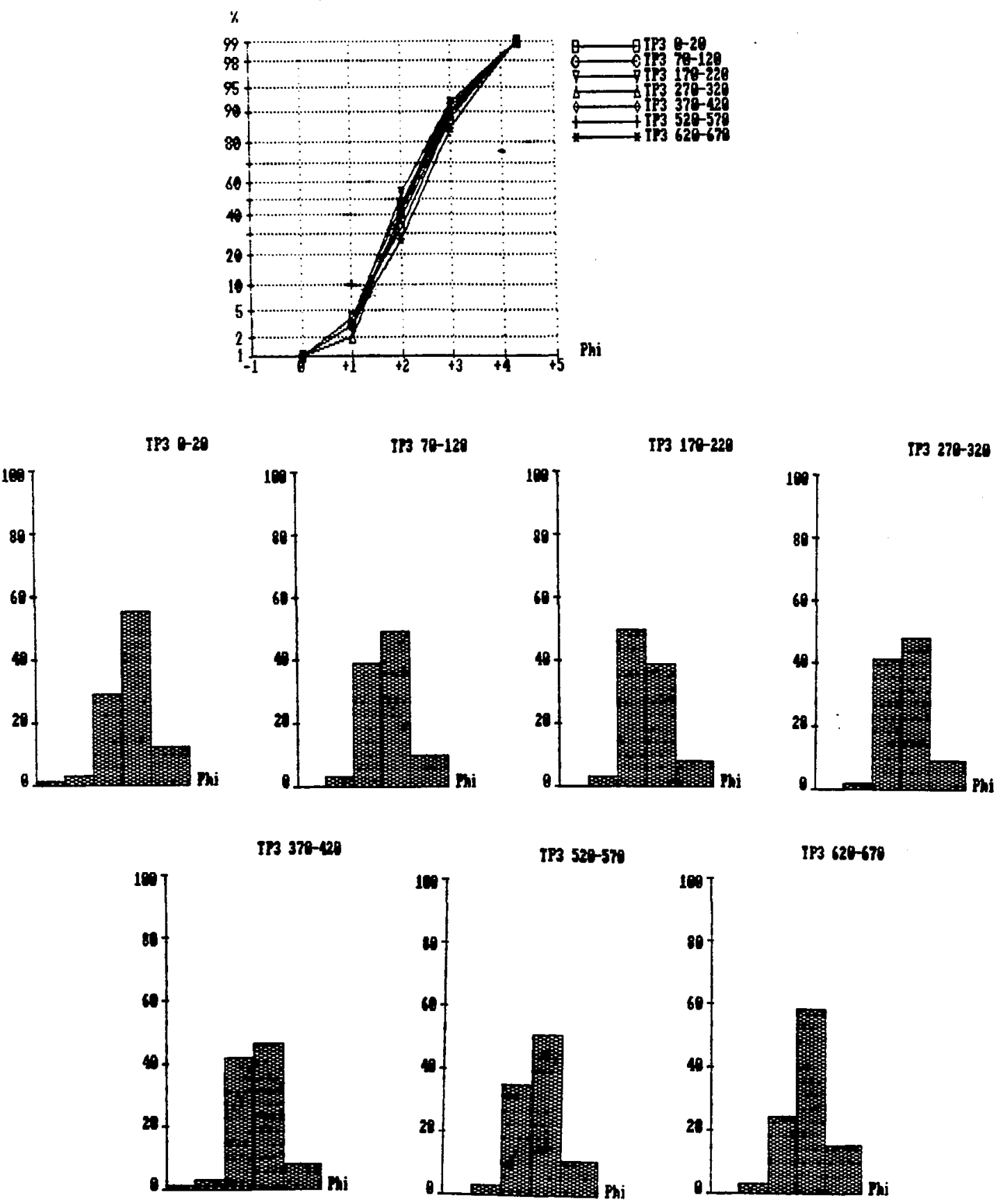

Figura 15: Distribuição de cinco frações de areia na tradagem profunda TP3. 
$\mathrm{Na}$ transição entre o material arenoso e o material argiloso observa-se uma mudança na distribuição das areias. Duas tradagens realizadas neste segmento, uma no começo onde a "stoneline" aparece a $1 \mathrm{~m}$ de profundidade e outra praticamente no meio onde a "stoneline' aparece a $270 \mathrm{~cm}$, mostraram uma diferença acentuada na distribuição de areias acima e abaixo da stoneline (Figura 16 e Figura 17) (Apêndice 2). Na primeira tradagem (TPC1) observa-se um aumento nas frações areia muito grossa e grossa nos histogramas das amostras abaixo da linha de pedra em relação às amostras de cima, assim como um pior grau de seleção do material. Na segunda tradagem (TPC2) acentua-se este contraste na distribuição das areias, aumentando significativamente a proporção de areia muito grossa e grossa e o empobrecimento do grau de seleção do material abaixo da linha de pedra.

A distribuição das areias num barranco de estrada, onde o material argiloso vermelho encontra-se sobre o diabásio separados por uma linha de pedras, mostrou uma repetição da tendência observada nas tradagens TPC1 e TPC2 (Figura 18). Observa-se nos gráficos de distribuição acumulada dois grupos nítidos de linhas revelando a diferença da distribuição das areias nos dois materiais. A mesma tendência de aumento da areia muito grossa e grossa observada nas tradagens acima citadas repete-se neste local. Deve-se salientar que o material que se encontra abaixo da linha de pedras neste local é a alterita de diabásio e não os sedimentos da formação Irati observados nas tradagens TPC1 e TPC2, e que a distribuição das areias do material acima da "stoneline" é muito semelhante nos três pontos de amostragem, predominando a areia fina e média.

Nas análises micromorfológicas observou-se o grau de arredondamento do quartzo. Várias lâminas foram estudadas mostrando que o grau de arredondamento dos grãos de quartzo acima da stoneline era maior que os grãos de baixo. Abaixo da mesma observou-se o predomínio de grãos de quartzo subangulares enquanto que acima os grãos de quartzo apresentavam-se subarredondados. 

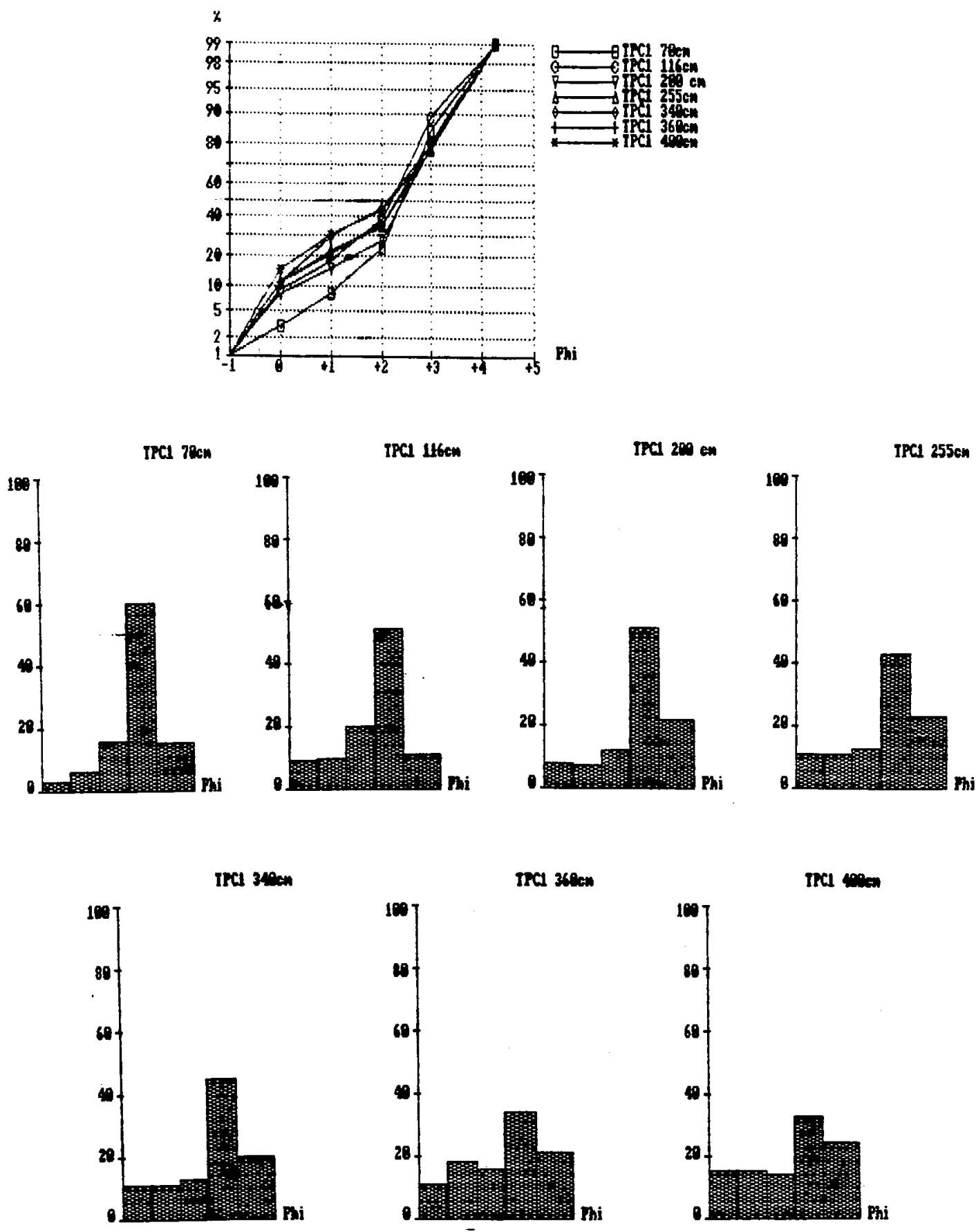

Figura 16: Distribuição de cinco frações de areia na tradagem profunda TPC1 

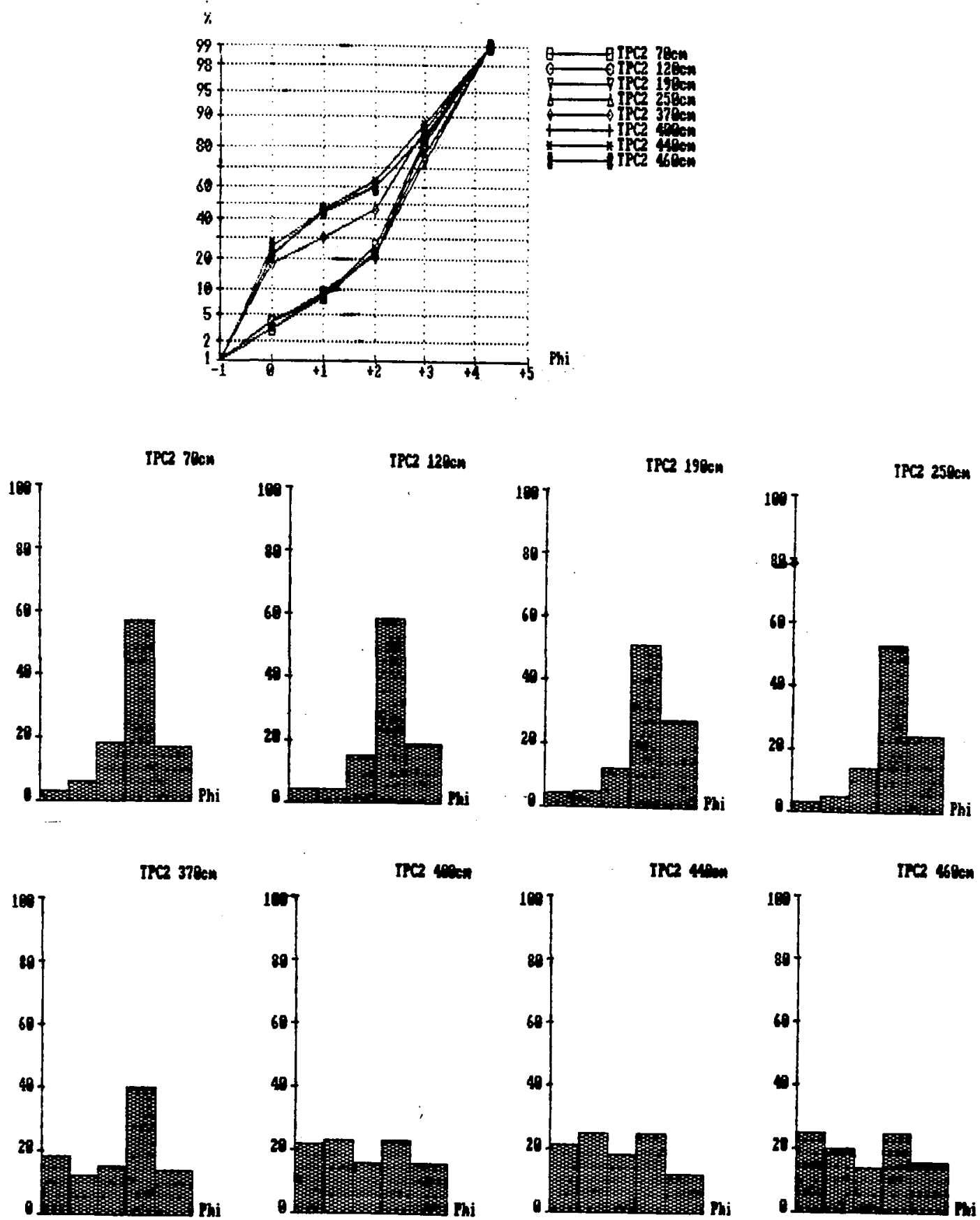

Figura 17: Distribuição de cinco frações de areia na tradagem profunda TPC2. 

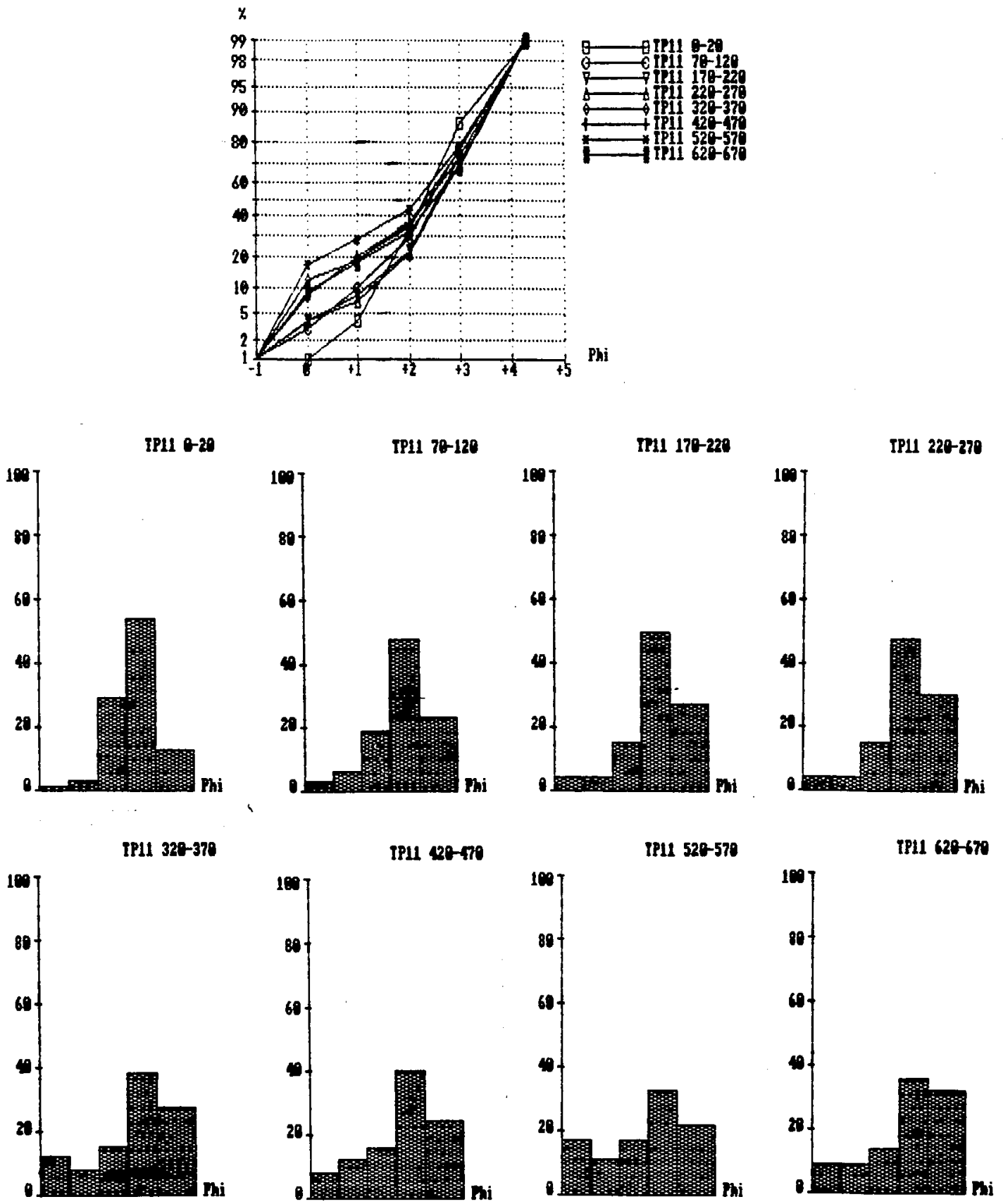

Figura 18: Distribuição de cinco frações de areia na tradagem profunda TP11. 
As observações e as análises realizadas convergem no sentido da existência de uma descontinuidade litológica entre o material arenoso e os sedimentos pelíticos da formação Irati, e outra entre o material vermelho e argiloso e os sedimentos da formação Irati e o sill de diabásio. Estas descontinuidades são evidenciadas na área com a presença de "stonelines" que concordando com as idéias de Ruhe (1959), Tricart (1959), Bigarella \& Mousinho (1965), Ab'saber (1966), Ranzani et al. (1972) e Lichte (1990, 1991) são de origem alóctone.

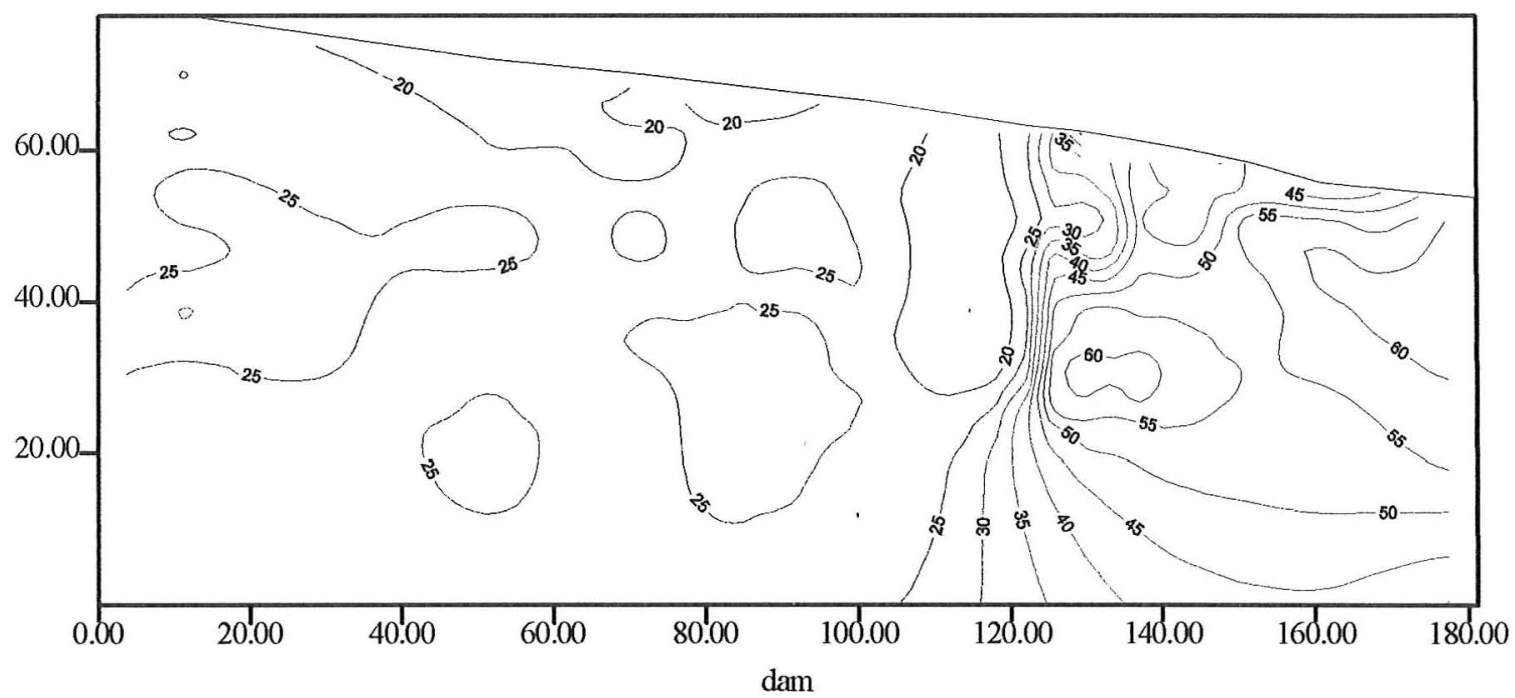

Figura 19: Gráfico de isolinhas mostrando a variação do teor de argila total no topo da topossequência

A presença de descontinuidades litológicas entre os diferentes materiais e de duas "stonelines" de origem alóctone em posições diferentes, confirma a existência de dois eventos deposicionais distintos, que ocorreram em períodos diferentes. Estes eventos teriam sido ocasionados pelas alternâncias climáticas que aconteceram durante o quaternário. $\mathrm{O}$ primeiro evento refere-se ao transporte e posterior deposição de material arenoso fino em barramentos tectônicos formados por soleiras regionais, durante o período semi-árido correlacionado com a fase glacial Danube, formando o pedimento Pd1. Estas soleiras eram formadas pelos sills e diques de diabásio que foram expostos durante a escavação da Depressão Periférica. O pedimento Pd1 foi entalhado em fase úmida posterior (durante uma 
fase interglacial). Após este entalhamento, o segundo evento deposicional ocorreu durante uma fase semiárida, contemporâneo do glacial Gunz, com erosão e posterior agradação formando o depósito pedimentar argiloso e vermelho inclinado em direção ao Rio Piracicaba, que estaria correlacionado com o pedimento P2. Este material argiloso teria sido um colúvio originado pelo retrabalhamento de material do própio sill de diabásio com contribuição do material arenoso fino. Uma pedogênese posterior destes materiais resultaria na formação de solos de texturas muito contrastantes a curta distância, evidenciados pela transição abrupta observada nos teores de argila total destes solos na Figura 19.

\subsection{Solos.}

\subsubsection{Mapa de Solos}

O mapa de solos da área de estudo (Vidal-Torrado et al. $\left.{ }^{5}, 1993\right)$ pode observar-se na Figura 5. Nos segmentos estudado foram identificados quatro tipos de solos:

LV Latossolo Vermelho-Amarelo álico, A moderado, textura média (Typic Hapludox).

TRL Terra Roxa Estruturada Latossólica eutrófica, A moderado, textura argilosa/muito argilosa (Kandiudalfic Eutrudox).

TR1 Terra Roxa Estruturada eutrófica, A moderado, textura argilosa/muito argilosa (Kandiudalfic Eutrudox)

TR4 Associação Terra Roxa Estruturada eutrófica pouco profunda, A moderado ou chernozêmico, textura argilosa, fase pedregosa (Rhodic Kandiudalf) + Terra Roxa Estruturada eutrófica, A moderado, textura argilosa (Rhodic Kandiudalf) +

${ }^{5}$ VIDAL-TORRADO, P.; SPAROVEK, G.; COOPER, M.; OLIVEIRA, M.C. de \& VILAS BOAS DO PRADO, G. Mapa pedológico detalhado do Campus "Luiz de Queiroz". Escola Superior de Agricultura "Luiz de Queiroz". 1993.Não publicado. 
Cambissolo eutrófico, A moderado ou chernozêmico, $\mathrm{Tb}$, textura argilosa, substrato diabásio, fase pedregosa (Typic Eutrochrept).

O Latossolo Vermelho-Amarelo localiza-se no topo da topossequência e desenvolve-se sobre os depósitos arenosos oriundos do primeiro evento de deposição cenozóico. Observa-se que o material de origem dos solos Terra Roxa Estruturada Latossólica e Terra Roxa Estruturada, ubicados no topo e ombro respectivamente, são os depósitos argilosos provenientes do segundo evento de pedimentação. O diabásio é o material de origem da Terra Roxa Estruturada pouco profunda localizada no começo da meia encosta. Na Figura 6 observa-se a disposição destes solos e a conformação dos horizontes na topossequência.

\subsection{2) Morfologia dos solos.}

Foram estudados quatro perfis ( $\mathrm{P} 1, \mathrm{P} 2, \mathrm{P} 3$ e $\mathrm{P} 4)$ localizados no topo, ombro e começo da meia encosta da topossequência (Figura 6), já que foi nesta porção que observouse o melhor desenvolvimento dos horizontes $\mathrm{Bw}$ e $\mathrm{Bt}$ e a transição entre eles. Os três primeiros situam-se sobre a cobertura cenozóica argilosa e o último sobre o diabásio.

O perfil P1 locado no topo da topossequência (Figura 20 e Figura 21) (Apêndice 3), descrito no barranco da estrada que vai para o bairro Monte Alegre, foi classificado como uma Terra Roxa Estruturada Latossólica. Neste perfil observam-se dois horizontes Bt entre os horizontes Ap e Bw. Estes se caracterizam por apresentar estrutura em blocos subangulares médios de consistência friável apresentando cerosidade comum com desenvolvimento fraco sendo que a quantidade de cerosidade do primeiro $\mathrm{Bt}$ e maior que no segundo. Logo abaixo destes horizontes encontra-se um horizonte $\mathrm{Bw}$ que apresenta estrutura em blocos subangulares de tamanho médio e grau fraco que se desfazem em microagregados de grau forte e consistência muito friável. Dentro da matriz deste horizonte observou-se a presença de alguns nódulos de argila. Separando este horizonte $\mathrm{Bw}$ de outro subjacente encontra-se um horizonte adensado que caracteriza-se por apresentar estrutura em blocos subangulares de tamanho médio e grau forte. A consistência deste é friável e pode-se 
observar a presença de cerosidade moderada e comum que predomina nas faces verticais dos agregados. Embaixo deste horizonte aparece outro horizonte Bw com estrutura em blocos fracos que se desfazem em microagregados de grau forte e consistência friável. Observou-se também, neste horizonte, a presença de nódulos de argila concentrados na parte superior, $o$ desenvolvimento de agregados subangulares de tamanho médio e grau forte com cerosidade moderada na transição com o horizonte adensado e a presença de alguns seixos arredondados e pequenos de quartzo. Uma linha de pedras encontrou-se separando este horizonte e a alterita de diabásio (Figura 20 e Figura 21). Esta apresenta seixos de quartzo arredondados, de tamanho centimétrico variando de 1 a $7 \mathrm{~cm}$ e $30 \mathrm{~cm}$ de espessura. A atividade biológica neste perfil é muito evidente encontrando-se em todos os horizontes crotovinas e pedotúbulos.

Ainda no topo estudou-se um segundo perfil (P2) (Figura 20 e Figura 21) (Apêndice 3) que foi classificado também como uma Terra Roxa Estruturada Latossólica. Neste perfil os horizontes $\mathrm{Bt}$ apresentavam estrutura em blocos subangulares de tamanho médio, abundante cerosidade recobrindo os agregados de grau moderado a forte $\mathrm{e}$ consistência friável. A diferença entre o horizonte Bt1 e Bt2 esta no grau de agregação sendo muito forte no primeiro e moderado no segundo. $\mathrm{O}$ horizonte $\mathrm{Bw}$ caracteriza-se por apresentar estrutura em forma de blocos subangulares de grau fraco que se desfazem em microagregados de grau forte de $1-2 \mathrm{~mm}$, cerosidade fraca e pouca, e uma consistência muito friável. Em todo o perfil observou-se porosidade predominatemente tubular de tamanho pequeno e alguns poros fissurais principalmente nos horizontes Bt. É nítida a atividade biológica caracterizada por pedotúbulos preenchidos por material e a porosidade tubular. Numa tradagen profunda feita no fundo da trincheira identificou-se, aos $5 \mathrm{~m}$ de profundidade uma linha de pedras com uma espessura de $20 \mathrm{~cm}$ com seixos menores que aos observados no perfil anterior.

No ombro, o perfil estudado (P3) (Figura 21) (Apêndice 3) foi classificado como Terra Roxa Estruturada. O horizonte Bt1 caracterizou-se por apresentar estrutura em blocos subangulares de grau forte e tamanho médio constatando-se também a presença de agregados prismáticos de grau forte e tamanho médio, consistência friável e cerosidade comum a 
A
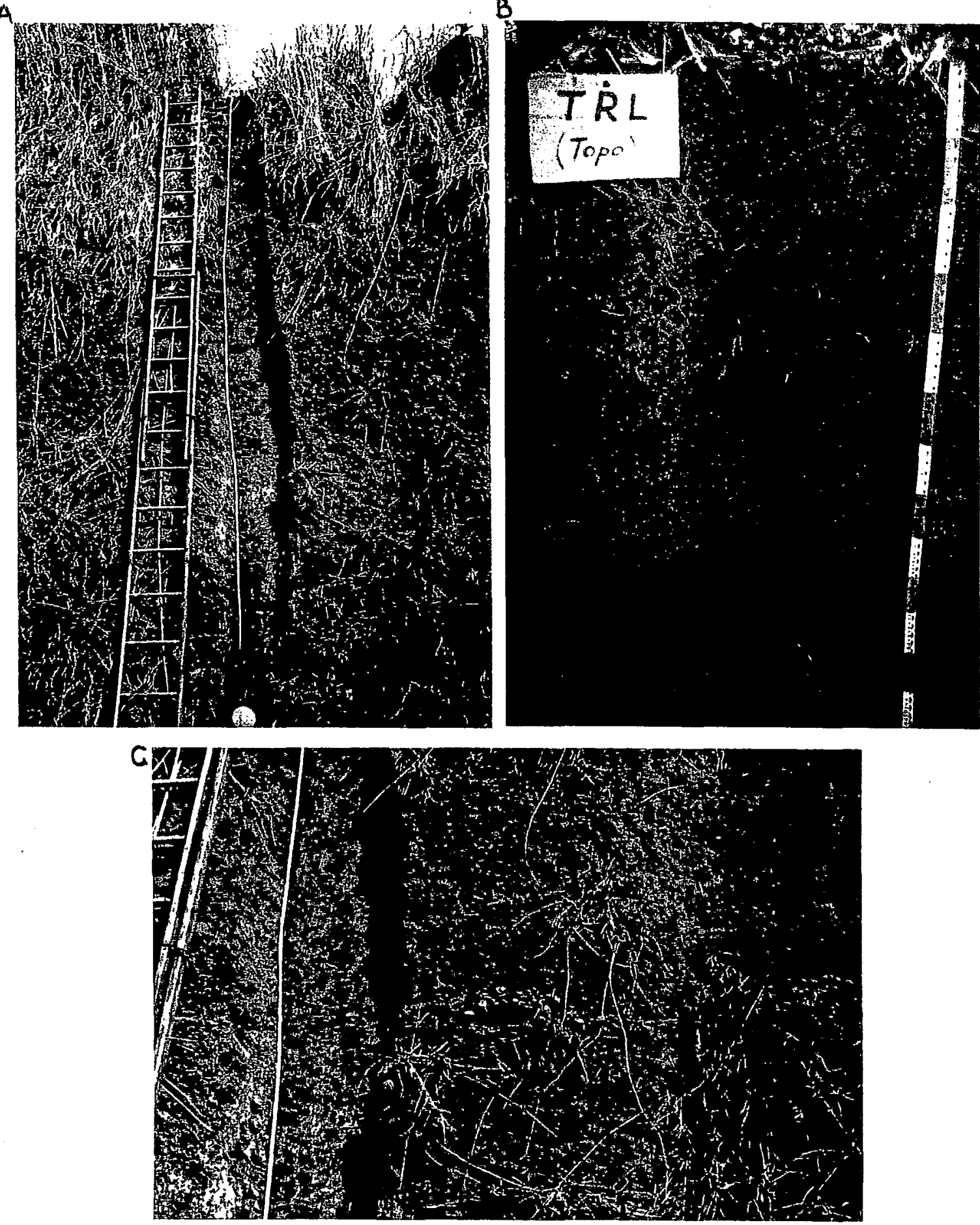

Figura 20: Fotografias dos perfis estudados: A) Perfil 1 (Barranco de estrada) (P1) e B) Perfil 2 (P2) e C) Detalhe da segunda "stoneline". 


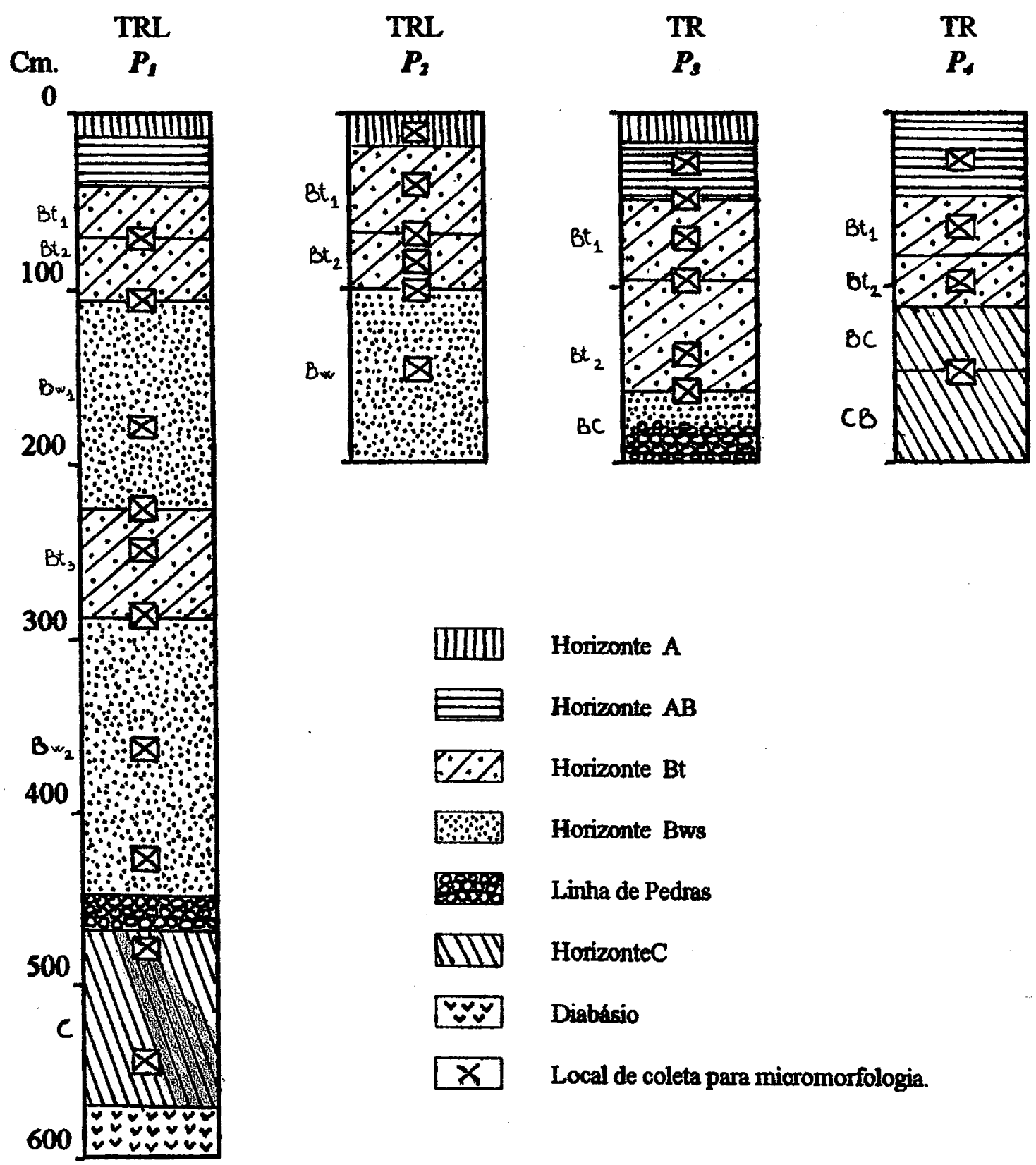

Figura 21: Esquema da disposição dos horizontes nos perfis estudados. 
abundante e de grau moderado. Um segundo horizonte $\mathrm{Bt}(\mathrm{Bt} 2)$ apresentou estrutura prismática de tamanho médio e grau moderado, consistência friável e cerosidade comum e de grau moderado que diminui um pouco em relação ao horizonte Bt1Observou-se a presença de uma porosidade tubular, de tamanho pequeno, e outra fissural bastante desenvolvida. Na base da trincheira observou-se a presença da linha de pedras de $15 \mathrm{~cm}$ de espessura e tamanho de seixos variando de $0,5-3 \mathrm{~cm}$. Como nos outros perfis, a atividade biológica intensa está evidenciada pela elevada porosidade tubular e a presença de crotovinas. Encontrou-se em uma das paredes da trincheira um cupinzeiro de caráter endógeno.O último perfil estudado (Figura 21) (Apêndice 3) situa-se no começo da meia encosta e foi classificado como uma Terra Roxa Estruturada pouco profunda. Caracteriza-se por apresentar material intemperizado e litorelíquias de diabásio no meio do perfil. Dois horizontes $\mathrm{Bt}$ foram descritos. A estrutura em blocos subangulares de grau forte e tamanho médio, a pouca cerosidade de grau moderado e a consistência friável caracterizam o horizonte Bt1. O horizonte Bt2 caracteriza-se por apresentar estrutura em forma de blocos subangulares e prismática de grau forte e tamanho médio e consistência friável. A cerosidade aumenta neste horizonte em relação ao horizonte Bt1, sendo caracterizada como comum e de grau moderado. Observa-se neste perfil o desenvolvimento de grande quantidade de raízes e de preenchimentos biológicos como pedotúbulos e crotovinas. Não foi constatada a presença de linha de pedras a partir desta posição.

Como resultado das descrições morfológicas, surgiram as questões, relatadas a seguir: a) qual é a origem dos microagregados do Bw, b) gênese do horizonte B textural, c) como se dá a transição entre os horizontes $\mathrm{Bt}$ e $\mathrm{Bw}$, d) origem das stonelines, e) qual a relação entre os perfis e f) qual a relação disso tudo com a evolução apontada pela revisão de literatura a esse respeito.

\subsection{3) Micromorfologia dos solos.}

A descrição sistemática da micromorfologia dos perfis estudados está apresentada na forma de quadros-resumo no Apêndice 5. A seguir serão relatadas as principais 
características micromorfológicas e as interpretações dadas para cada perfil.

Perfil 1 (P1):

Em síntese, o perfil1 (P1) apresenta tais características dominantes por horizonte. $\mathbf{O}$ horizonte Bt1 caracteriza-se por apresentar um plasma isótico e uma trama porfírica fechada onde predomina uma porosidade cavitária mamelonada e fissural (Figura 29). Observou-se a presença de cutãs de difusão e ferriargilãs de iluviação (2,5\%) (Figura 31). O esqueleto é quartzoso subarredondado e moderadamente a mal selecionado.

As observações feitas no horizonte $\mathrm{Bt} 2$ mostraram que este apresenta uma trama porfírica fechada, havendo uma tendência local para enáulica. O plasma se apresentou isótico com alguns domínios vossépicos. Predomina neste horizonte uma porosidade cavitária mamelonada e fissural (Figuras 29 e 30). Observou-se a presença de cutãs de difusão e ferriargilãs de iluviação (5\%) (Figura 31). O esqueleto é quartzoso subarredondado e moderadamente mal selecionado (Figura 25).

O horizonte Bw1 apresenta duas zonas; uma, predominante, com trama enáulica e outra com trama porfírica fechada (Figura 28). O plasma é isótico apresentando domínios esquelvomassépicos nas zonas adensadas. $Q$ esqueleto é quartzoso subarredondado e moderadamente mal selecionado, apresentando-se triado dentro de alguns microagregados ovais (Figuras 24 e 26).

Embaixo do horizonte Bw1 observa-se a presença de um horizonte adensado denominado Bt3. Este horizonte apresenta uma trama porfírica fechada com predomínio de poros fissurais e a presença de alguns canais. O plasma é isótico e o esqueleto é quartzoso subarredondado e moderadamente mal selecionado.

O horizonte Bw2 caracteriza-se por apresentar uma trama enáulica, predominando a porodidade de empilhamento complexo com presença de algumas ortocavidades mamelonadas (Figura 25). O plasma é isótico. $\mathrm{O}$ esqueleto apresenta-se quartzoso subarredondado e mal selecionado, dentro de alguns microagregados ovais apresenta-se triado. Na base deste horizonte observa-se uma "stoneline" formada por seixos de quartzito de diâmetros variando de $0,5 \mathrm{~cm}$ até $5 \mathrm{~cm}$. 
$\mathrm{Na}$ transição entre os horizontes $\mathrm{Bt} 2$ e Bwl passa-se de uma trama porfírica para uma enáulica (Figura 27), predominando no primeiro uma porosidade cavitária e fissural e no segundo uma porosidade de empilhamento com algumas ortocavidades e fissuras.

A passagem do horizonte Bw1 para o Bt3 é marcada por um adensamento do fundo matricial passando de enáulica no Bw1 para porfírica fechada no Bt3. Observa-se nesta transição uma intensa fissuração do material adensado formando microagregados poliêdricos (Figura 27). O caminho inverso foi observado na transição entre o horizonte Bt3 e Bw2 ocorrendo a passagem de uma trama porfíca para uma enáulica onde predomina a porosidade de empilhamento e algumas ortocavidades mamelonares (Figura 25). Nesta transição observa-se também a intensa fissuração do material adensado.

Embaixo da "stoneline" observa-se a presença de um horizonte $\mathbf{C}$ que apresenta uma trama porfiro-enáulica com plasma isótico com tendência bimassépica. $\mathrm{O}$ esqueleto $\mathrm{e}$ predominantemente material do diabásio e o quartzo encontrado é subangular e moderadamente a bem selecionado (Figuras 33 e 34). Este horizonte sofre uma transição gradual para a alterita de diabásio, passando para uma trama porfírica onde aumenta a quantidade do material do diabásio.

As observações feitas nos horizontes Bt1 e Bt2 mostram um aumento dos ferriargilãs de iluviação no $\mathrm{B} 2$, assim como o aparecimento de zonas localizadas caracterizadas por apresentar uma trama enáulica (Figura 22). O horizonte Bt3 se diferencia destes pela ausencia de ferriargilãs de iluviação e por possuir um fundo matricial mais denso e mais fissurado.

Os horizontes $\mathrm{Bt}$ e $\mathrm{Bw}$ apresentam-se bem diferentes. Ocorre entre estes uma transição gradual onde as principais diferenças são observadas nas tramas e no tipo de porosidade de cada um deles. Predominam no primeiro a trama porfírica e uma porosidade ortocavitária e fissural, enquanto que no segundo predominam uma trama enáulica e uma porosidade de empilhamento com algumas ortocavidades e fissuras (Figuras 22, 23, $29 \mathrm{e} 30$ ).

A principal diferença observada entre os horizontes $\mathrm{Bw} 1$ e Bw2 é a presença, no primeiro, de zonas porfíricas com porosidade ortocavitária e fissural dentro de uma trama predominante enáulica. Estas zonas porfíricas estariam relacionadas com os nódulos de argila 
observadas nas descrições morfológicas de campo. Nos dois horizontes observou-se a presença de três tipos de microagregados: ovais com esqueleto triado, ovais sem esqueleto triado e poliêdricos (Figura 23 e 25).

O horizonte $\mathrm{C}$ e a alterita de diabásio encontrados embaixo da "stoneline" se diferenciam do material acima da mesma pelo tipo de esqueleto e quartzo. Nestes horizontes o esqueleto e predominantemente material do diabásio, material este que não é observado acima da "stoneline" (Figura 35). O quartzo difere na sua forma e seleção, enquanto que acima da "stoneline" ele é subarredonadado e moderadamente a mal selecionado no material abaixo da "stoneline" ele é subangular e bem selecionado (Figuras 25 e 34).

Os estudos micromorfológicos deste perfil mostraram uma transição gradual e vertical entre horizontes $\mathrm{Bt}$ adensados com agregados poliêdricos e horizontes $\mathrm{Bw}$ microagregados. As observações sugerem a ocorrência de um adensamento dos microagregados nos horizontes $\mathrm{Bt}$, caracterizada pela presença de uma porosidade ortocavitária mamelonada dentro dos horizontes adensados e a presença de linha de fraqueza entre os microagregados coalescidos (Figura 30), assim como de ferriargilãs de iluviação que preenchem a porosidade entre os microagregados provocando a sua cimentação (Figura 31). Posterior a este adensamento estaria ocorrendo uma desestruturação destes horizontes adensados por um processo de fissuração da trama porfírica e formando agregados e microagregados poliêdricos (Figura 27).

A atividade biológica no perfil foi bastante significativa sendo evidenciada pela importante presença de pedotúbulos de dimensões variando de 1 até $5 \mathrm{~mm}$ de diâmetro e de diversas formas podendo ser elípticas, abobadadas, circulares e tubulares (Figura 24 a), e de microagregados ovais com esqueleto triado (Figura 26).

Observou-se uma descontinuidade entre o material acima e embaixo da "stoneline" evidencida pelas diferenças no tipo de esqueleto e quartzo.

Perfil 2 (P2):

Este perfil apresenta três horizontes: Bt1, Bt2 e Bw.

O horizonte Btl caracteriza-se por apresentar uma trama porfírica com predomínio de porosidade ortocavitária e fissural (Figura 29). O plasma é isótico encontrando-se 
domínios esquelvomassépicos. Este horizonte apresenta ferriargilãs de iluviação (5\%), cutãs de difusão e observou-se a presença de pápulas e neocutãs. $O$ esqueleto é quartzoso subarredondado e moderadamente selecionado (Figura 25).

Contrastando com o horizonte acima descrito, o horizonte $\mathrm{Bt} 2$ apresentou uma trama porfírica com alguns domínios enáulicos e predomínio de canais, ortocavidades e fissuras. O plasma é isótico com alguns domínios esquelvomassépicos. Observou-se a presença de ferri-argilãs de iluviação e cutans de difusão (3\%). O esqueleto apresenta-se quartzoso subarredondado e moderadamente selecionado. $O$ quartzo, neste horizonte, apresenta campos orientados.

No horizonte $\mathrm{Bw}$ observou-se uma pedalidade forte onde predominavam microagregados ovais e poliêdricos (Figura 23). Este horizonte apresenta uma trama enáulica com predomínio de porosidade de empilhamento e algumas fissuras. $\mathrm{O}$ plasma é isótico e o esqueleto é quartzoso subarredondado e moderadamente selecionado.

A transição entre os dois horizontes $\mathrm{Bt}$ mostrou a diminuição de ferriargilãs de iluviação e o desaparecimento das pápulas e neocutans. Observou-se o aparecimento de domínios enáulicos dentro da trama porfírica.

A transição entre os horizontes Bt2 e Bw é marcada pela passagem de uma trama porfírica para uma enáulica onde predominam as porosidades de empilhamento e fissurais (Figura 28). Esta mostrou duas zonas; uma, onde predominam agregados poliédricos com alguns campos de microagregados ovais e poliédricos e porosidade ortocavitária e fissural, e outra, onde predominam exclusivamente os microagregados ovais e poliédricos com porosidade de empilhamento e algumas fissuras (Figura 28).

A semelhança com o perfil anterior, este perfil mostra uma transição gradual e vertical entre horizontes $\mathrm{Bt}$ adensados e horizontes Bw microagregados. As evidências micromorfológicas mostram que o processo desta transformação estrutural seria o mesmo ao do perfil 1. A presença de pápulas e neo-cutãs sugeririam a movimentação da massa do solo por forças de contração e expansão e movimentação de ferro, respectivamente. 
A presença de pedotúbulos de diversas formas (elípticos, tubulares e abobadados) e de microagregados ovais com esqueleto triado evidenciaram a intensidade da atividade da fauna no solo neste solo (Figura 24 a).

\section{Perfil 3 (P3):}

Este perfil apresenta as seguintes características dominantes por horizonte.

O horizonte Btl apresenta uma trama porfírica com predominância de uma porosidade fissural e de ortocavidades mamelonadas e canais (Figura 29). O plasma é isótico com tendência a esquelvossépico. Observou-se a presença de ferriargilãs de iluviação (5\%) (Figura 31). O esqueleto é quartzoso subarredondado e mal selecionado.

No horizonte $\mathrm{Bt} 2$ observou-se uma trama porfírica onde predominam os poros fissurais e ortocavitários mamelonados (Figura 29). O plasma é isótico com domínios massépicos. Neste horizonte evidenciou-se a presença de ferriargilãs de iluviação (1\%) e de pápulas e quasi-cutans. O esqueleto é predominantemente composto por quartzo com grãos subarredondados e mal selecionados.

O horizonte BC caracterizou-se por apresentar duas zonas, uma porfírica e outra enáulica. Na primeira predominam as ortocavidades e fissuras enquanto que na segunda predominam a porosidade de empilhamento e ortocavidades. $\mathrm{O}$ plasma é isótico com alguns domínios argilassépicos e vossépicos. $\mathrm{O}$ esqueleto é predominantemente quartzoso subarredondado ou subangular. No topo deste horizonte observa-se uma "stoneline" formado por seixos de quartzo de tamanhos variando de 0,5 a $2 \mathrm{~cm}$ de diâmetro.

A transição entre os horizontes Bt1 e Bt2 mostra uma diminuição dos ferriargilãs de iluviação e o aparecimento de pápulas e quasi-cutans. A fissuração aumenta no horizonte $\mathrm{Bt} 2$. Entre os horizontes $\mathrm{Bt} 2$ e BC observa-se o aparecimento de domínios com trama enáulica e a presença nestes de microagregados ovais e poliêdricos.

Este perfil apresenta-se como caracterítico de uma Terra Roxa Estruturada com presença de agregados poliêdricos com pedalidade moderada a forte. As evidências mostram que os horizontes deste perfil sofreram um adensamento resultante da coalescência de microagregados e da iluviação de argila, e que atualmente estão sofrendo uma fissuração 
com a consequente formação de agregados e microagregados poliêdricos no sentido ascendente.

A presença da "stoneline" evidencia uma descontinuidade entre os materiais acima e embaixo dela como mostrado na primeira parte do trabalho.

Perfil 4 (P4):

Localizado na meia encosta este perfil apresenta quatro horizonte: $\mathrm{Bt} 1, \mathrm{Bt}, \mathrm{BC}$ e CB.

O horizonte Bt1 caracteriza-se por apresentar uma trama porfírica e porosidade fissural e ortocavitária. Os agregados são subangulares e a pedalidade é moderada a forte. $\mathrm{O}$ plasma é isótico com domínios massépicos. $\mathrm{O}$ esqueleto é composto por grande quantidade de feldspatos e plagioclásios, oriundos do diabásio, e quartzo subarredonado ou subangular mal selecionado. Observou-se a presença de nódulos de 4-5mm de diâmetro.

No horizonte $\mathrm{Bt} 2$ observou-se um plasma isótico com trama porfírica e uma porosidade ortocavitária e fissural. Os agregados são subangulares e a pedalidade é moderada. $\mathrm{O}$ esqueleto é dominantemente material intemperizado do diabásio e quartzo subarredondado e subangular mal selecionado.

O horizonte $\mathrm{BC}$ apresenta um plasma isótico e agregados subangulares com pedalidade moderada a forte. Neste horizonte predominam as litorelíquias de diabásio (Figura 35) e há presença de quartzo subarredonadao ou subangular mal selecionado. Observou-se a presença de pápulas e feriargilãs de iluviação.

Finalmente, o horizonte CB apresenta um plasma isótico com alguns domínios silassépicos. A trama é porfírica com agregados poliêdricos subangulares. A porosidade predominante é ortocavitária e fissural. $\mathrm{O}$ esquelto é formado predominantemente por litorelíquias de diabásio e quartzo subarredondao ou subangular (Figura 35). Observou-se a formação de "stress-cutans" neste horizonte.

Neste perfil desaparecem as evidências de adensamento e coalescência de microagregados observadas nos perfis anteriores. A posição no relevo e a proximidade do material de origem determinam a sua pouca profundidade. As observações micromorfológicas mostraram a presença de muito material intemperizado de diabásio o que 
poderia sugerir que estes horizontes estejam sendo formados in situ derivados diretamente da alteroplasmação deste material. Este perfil não estaria ligada à dinâmica do topo e sim a uma dinâmica própria e mais atual.

Os três primeiros perfis (P1, P2 e P3) apresentam características semelhantes, observando-se, em todos eles, a transformação estrutural vertical e lateral entre horizontes adensados $\mathrm{Bt}$ e outros microagregados $\mathrm{Bw}$. Todos eles apresentam dois horizontes adensados Bt em superfície que de acordo com as evidências micromorfológicas seriam formados pela coalescência dos microagregados ou cimentaçào dos mesmos pela argila iluviada depositada na porosidade. Estes horizontes vão se espessando a medida que descemos na sequência até o desaparecimento do horizonte $\mathrm{Bw}$ no ombro. Também observa-se nestes perfis uma desestruturação destes horizontes adensados por fissuração no sentido ascendente formando agregados e microagregados poliêdricos que poderia ser interpretada como um processo mais atual.

Uma particulariedade observa-se no perfil 1 que não se repete nos outros perfis que é a presença de um horizonte adensado e bem fissurado no meio de dois horizontes $\mathrm{Bw}$.

Em todos eles três tipos de microagregados foram observados: ovais com esqueleto triado, ovais sem esquelto triado e poliêdricos sugerindo a participação de mais de um processo na formação dos microagregados. A atividade biológica também foi muito grande nestes perfis.

O ultimo perfil (P4) estaria desligado da dinâmica do topo e teria uma dinâmica própria para a formação dos horizontes Bt. Estes estariam se formando por processos de alteroplasmação do material de origem tendo uma gênese mais autóctone.

\section{3) Pedogênese da estrutura microagregada e poliédrica.}

Os estudos morfológicos e micromorfológicos mostraram a existência no topo da topossequência de uma transição entre um horizonte Bw e outro Bt (Figura 6). Esta transição ocorre tanto no sentido lateral como no sentido vertical e é o objetivo deste capítulo é tentar explicar os processos que levaram à formação destes horizontes e à sua transição. 


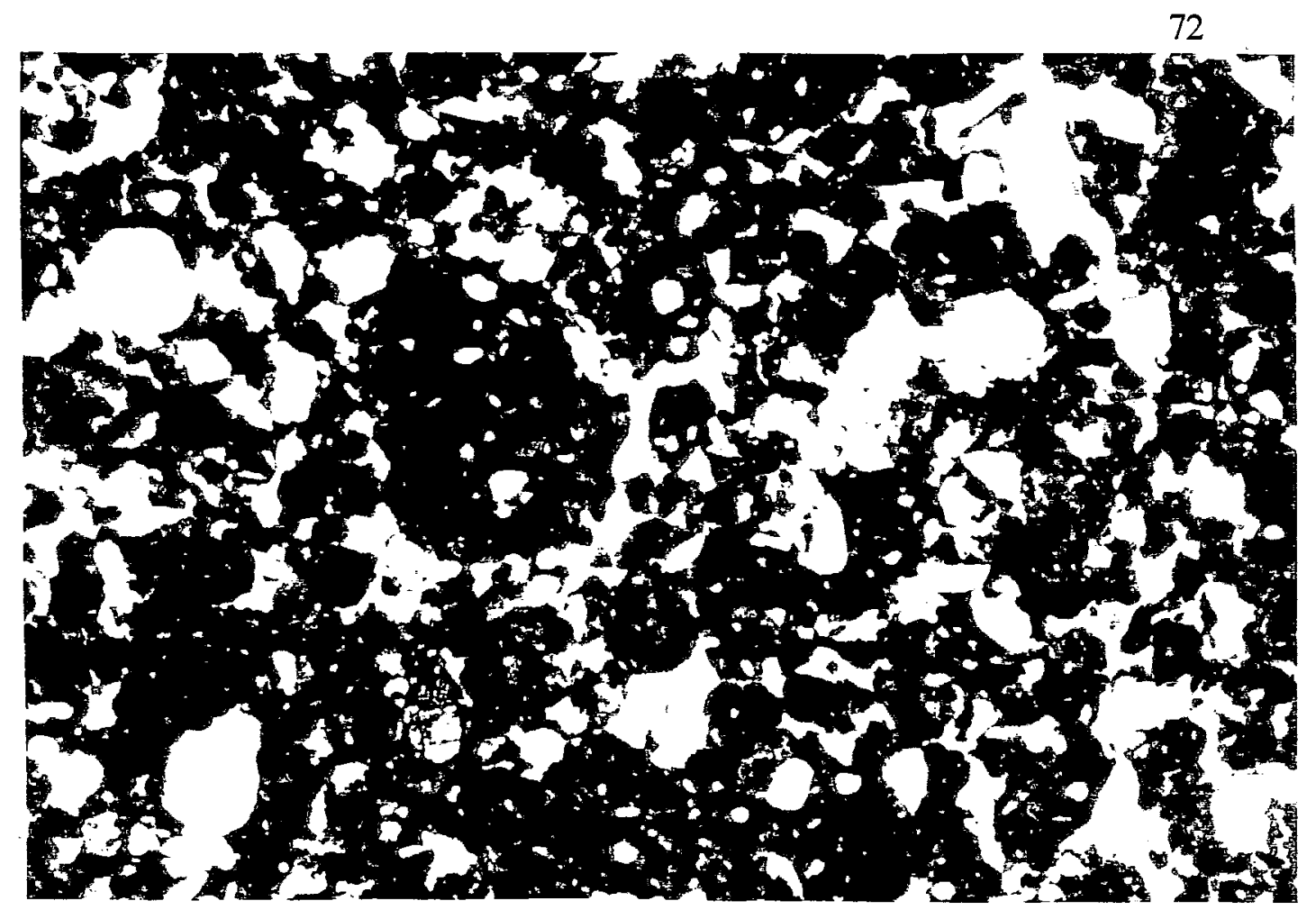

Figura 22: Fotomicrografia da transição entre os horizontes $\mathrm{Bt} 2 / \mathrm{Bw} 1$ do perfil 1 . Trama pórfiro-enáulica. Observa-se a coalescência de microagregados e a formação da porosidade policôncava. $(28 \mathrm{x})$

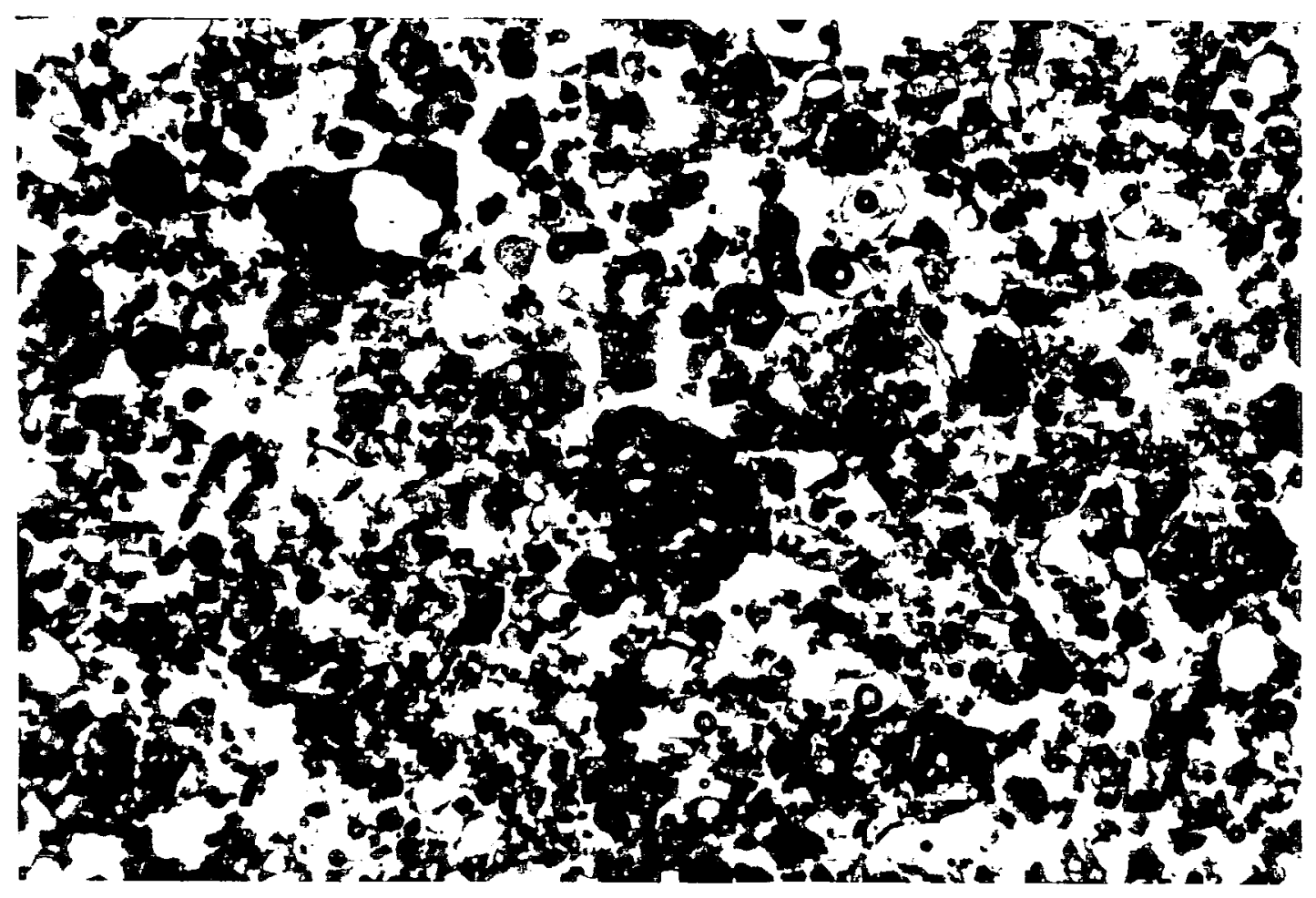

Figura 23: Horizonte Bw1 perfil 1. Trama enáulica. Observa-se a presença de microagregados ovais com esqueleto triado, ovais sem esqueleto triado e poliếdricos.(28x) 


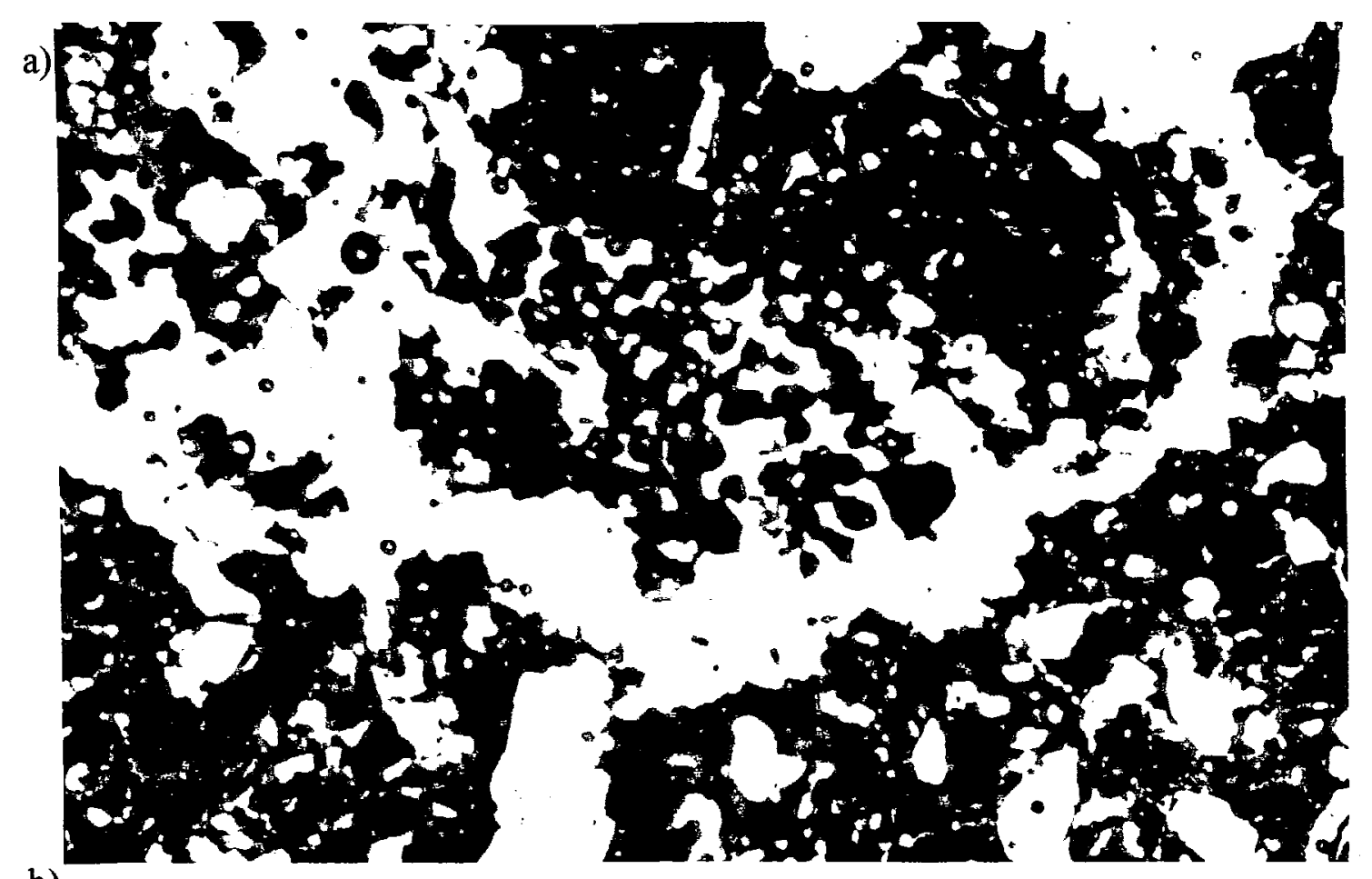

b)

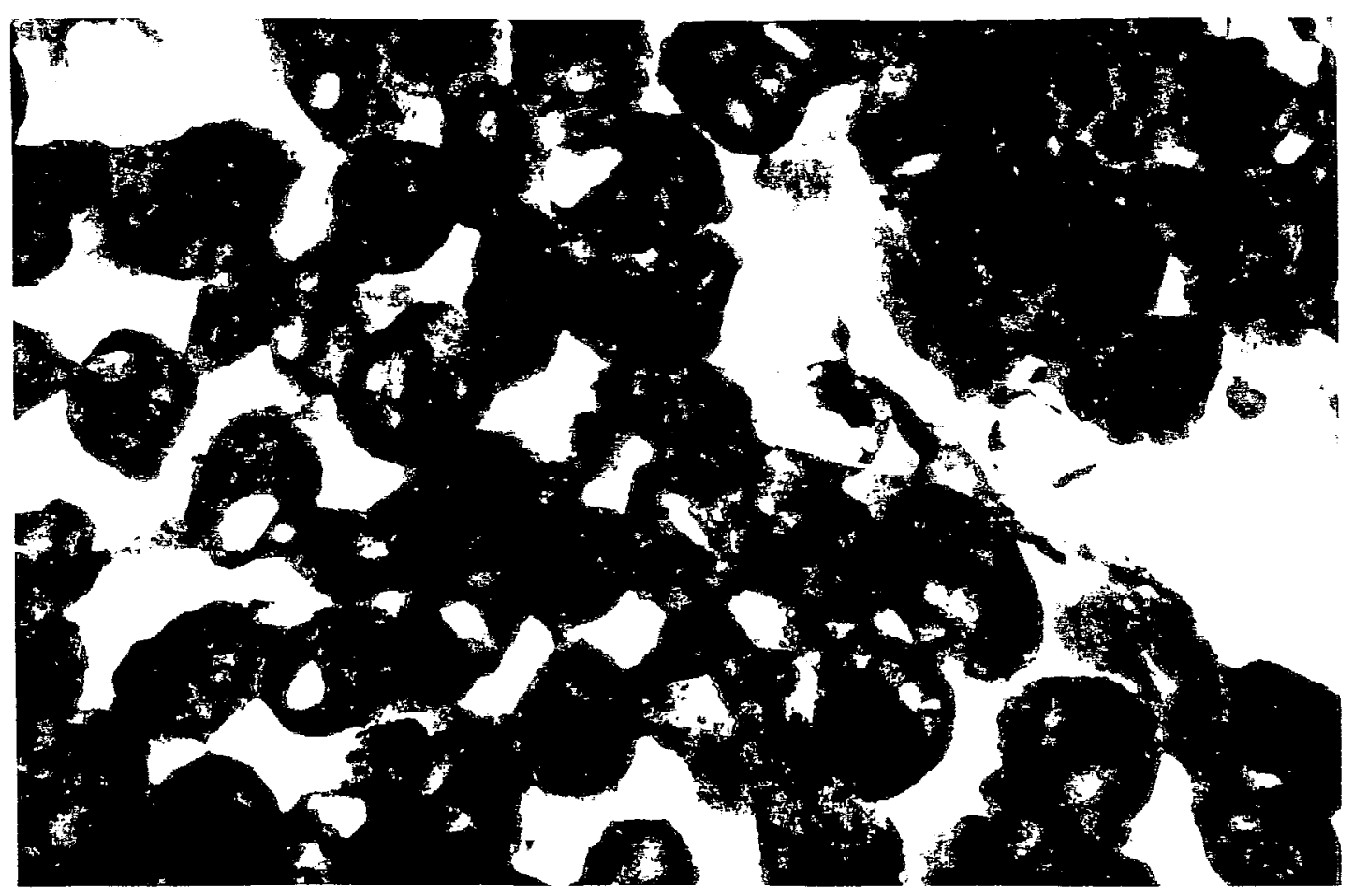

Figura 24: a) Microagregados ovais com esqueleto triado de origem biológica dentro de agrotúbulo (28x). b) Detalhe dos microagregados ovais com esqueleto triado. (138x) 


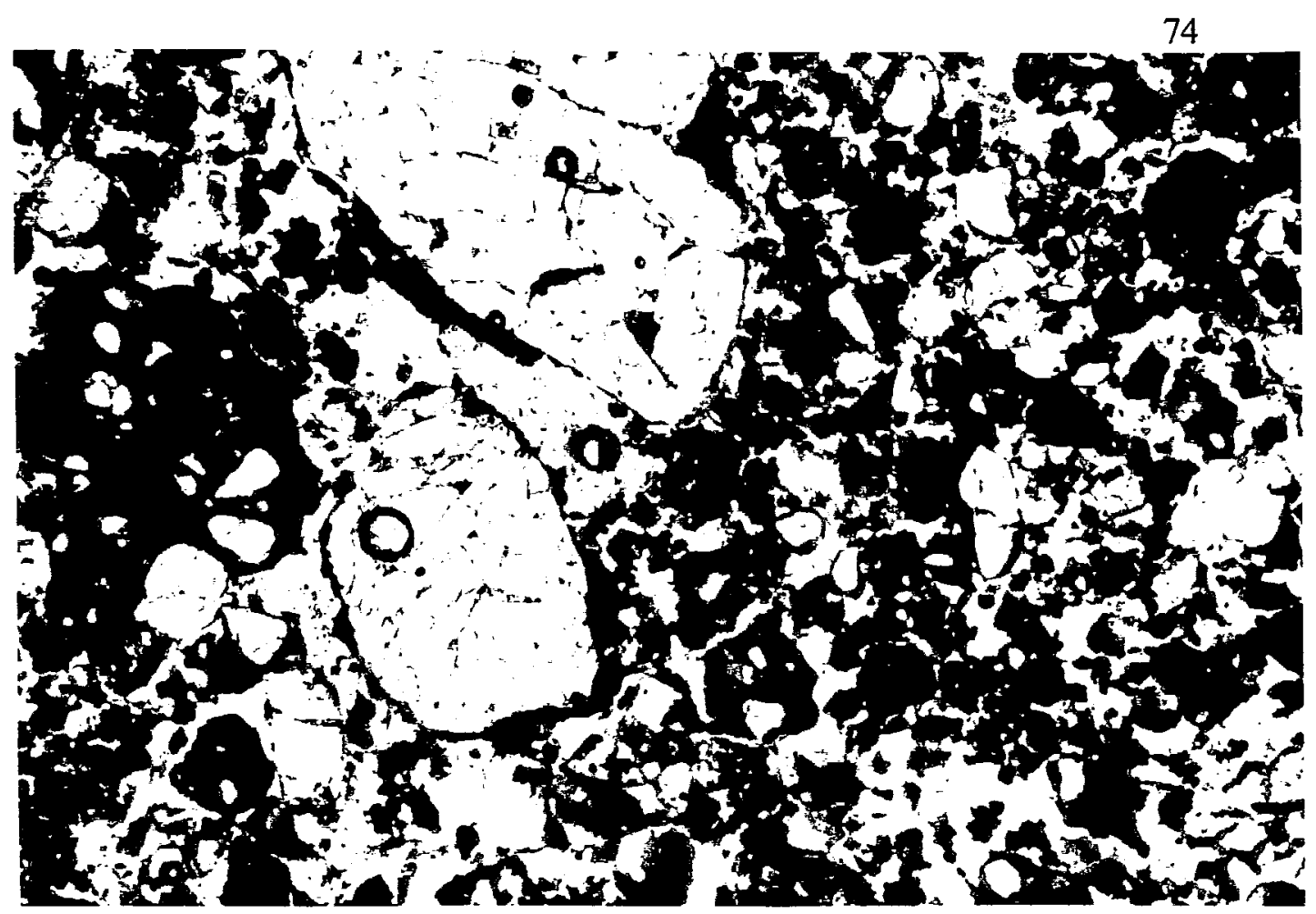

Figura 25: Horizonte Bw2, perfil 1 (P1).Trama enáulica. Quartzo subarredondado e mal selecionado.(28x)

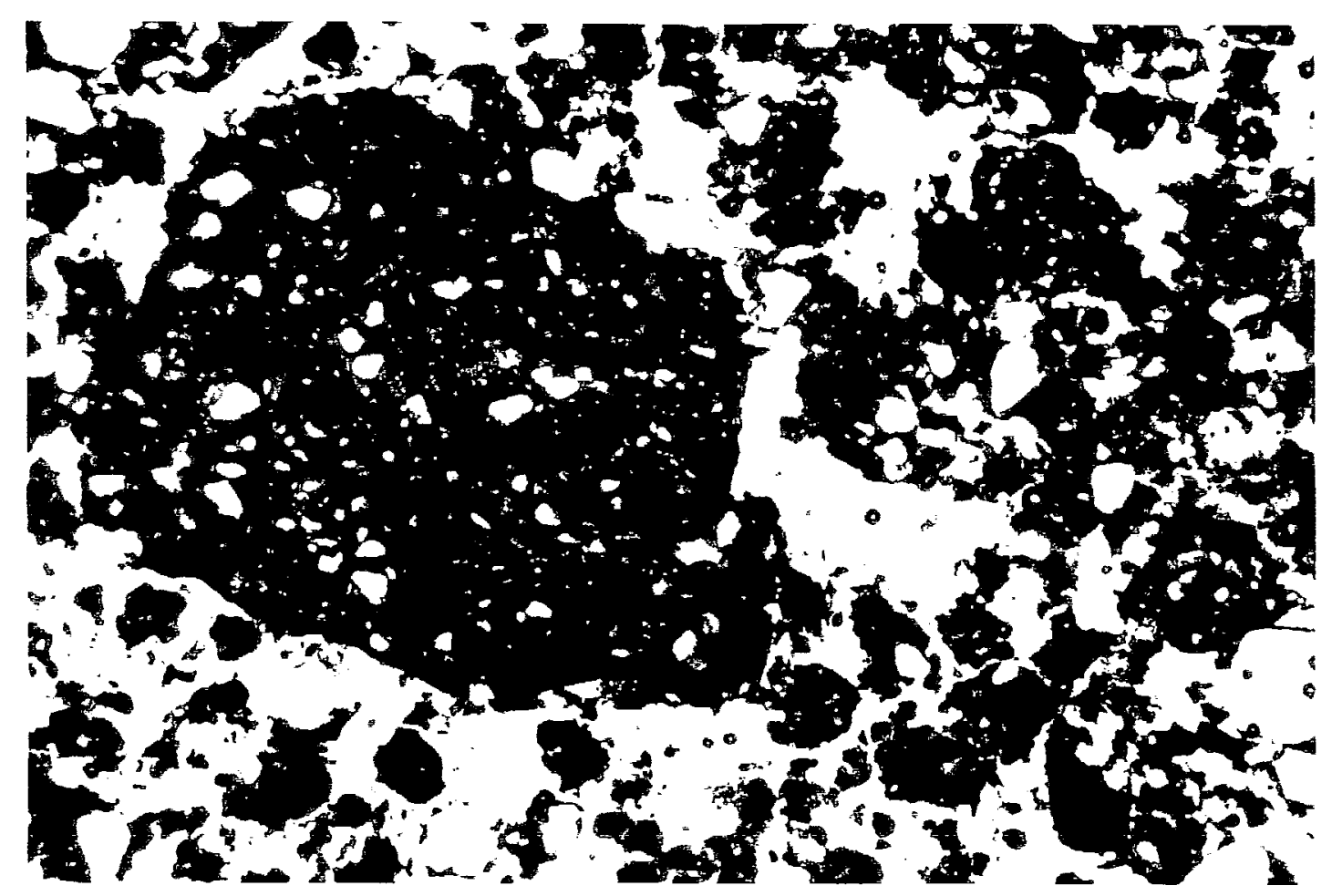

Figura 26: Detalhe de um microagregado oval com esqueleto triado de origem biológica. $(28 \mathrm{x})$ 




b)

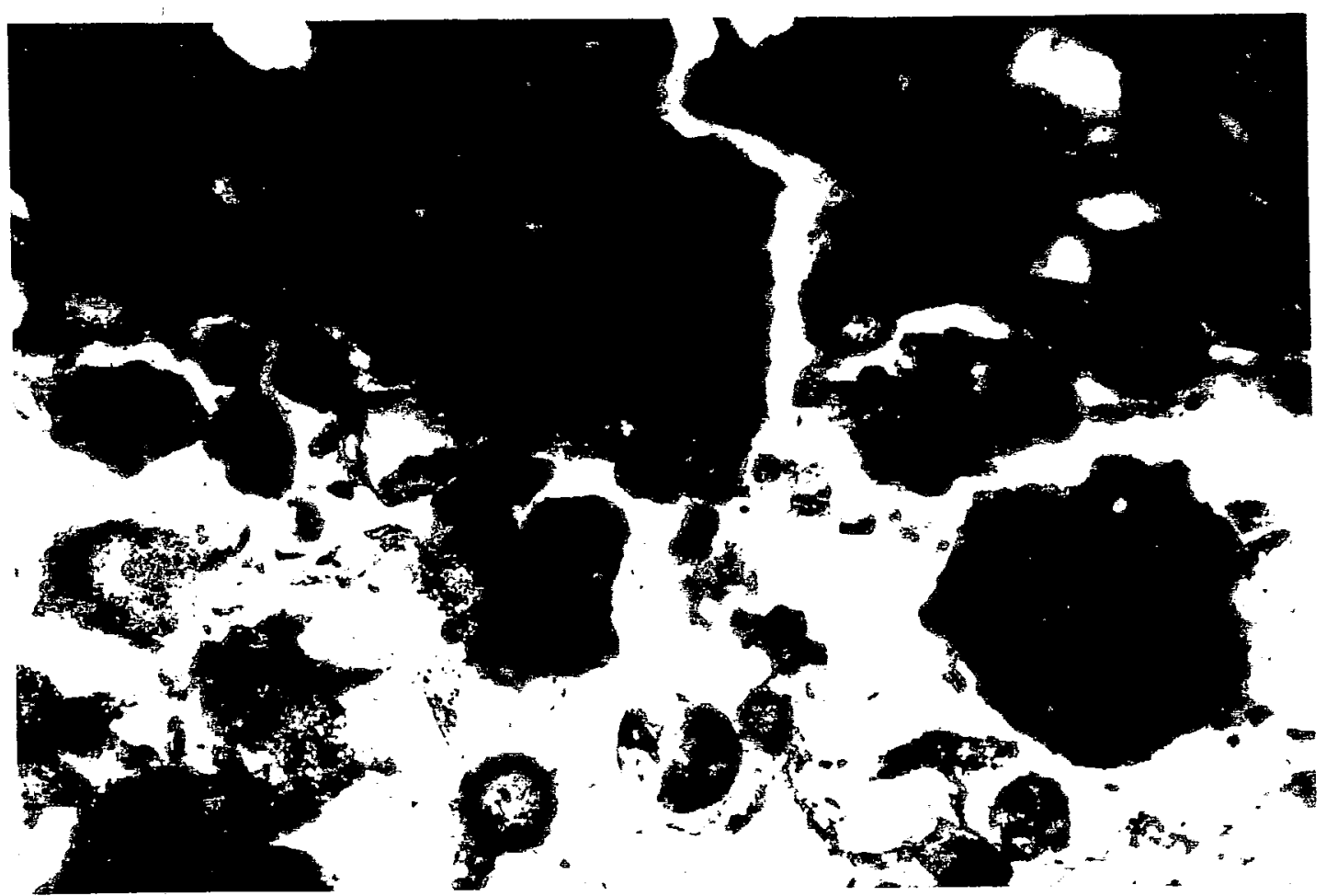

Figura 27: a)Transição abrupta entre uma trama porfírica e outra enáulica mostrando a fissuração do primeiro e a formação de microagregados poliếdricos por este processo (Transição Bw1/Bt3, perfil1) (28x).b) Detalhe da anterior (138x). 


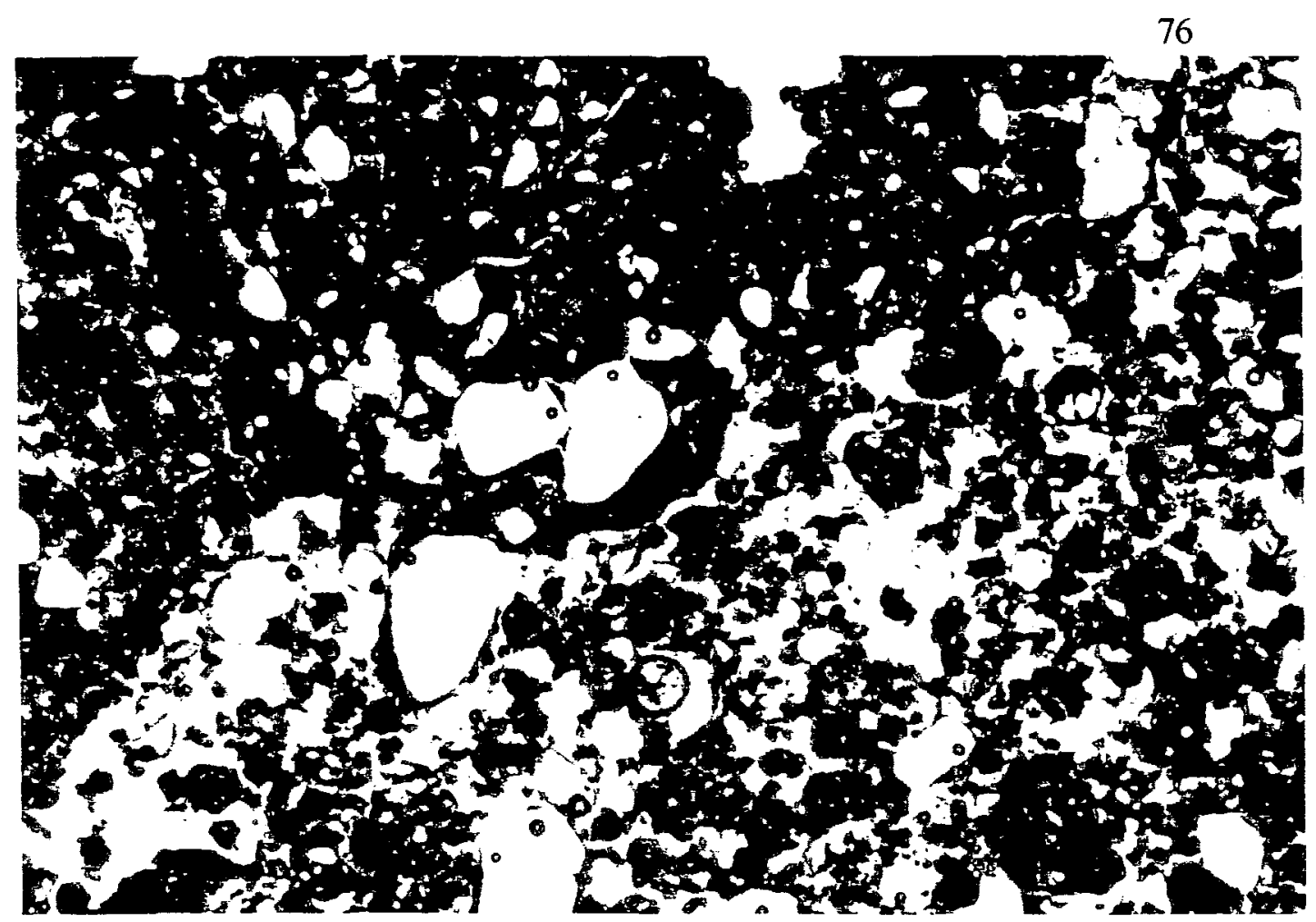

Figura 28: Transição abrupta entre a trama porfírica dos horizontes adensados e a trama enáulica característico dos horizontes $\mathrm{Bw}$. (28x)

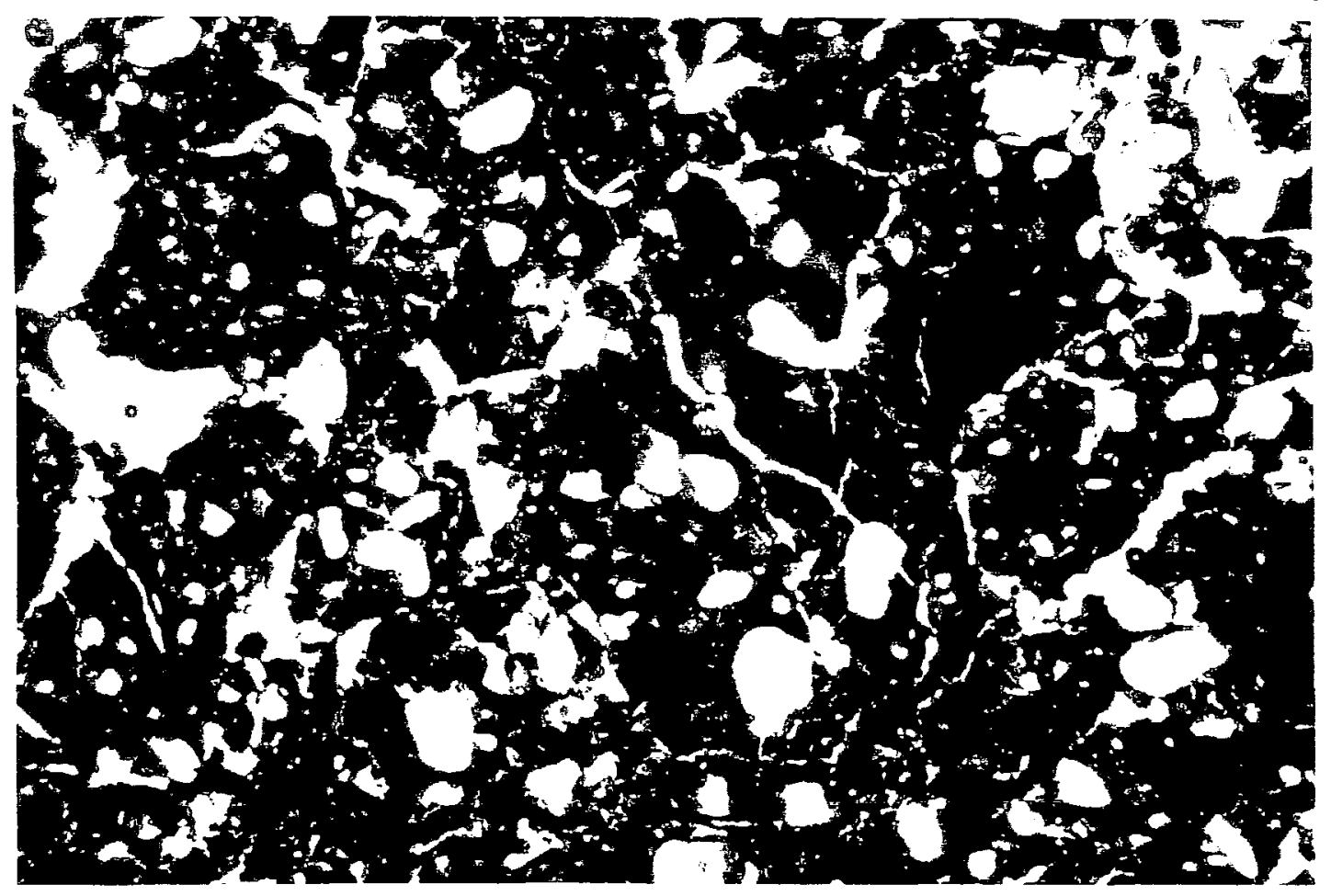

Figura 29: Trama porfirica fissurada, característico dos horizontes Bt adensados, formando agregados poliédricos $(28 \mathrm{x})$ 
a)

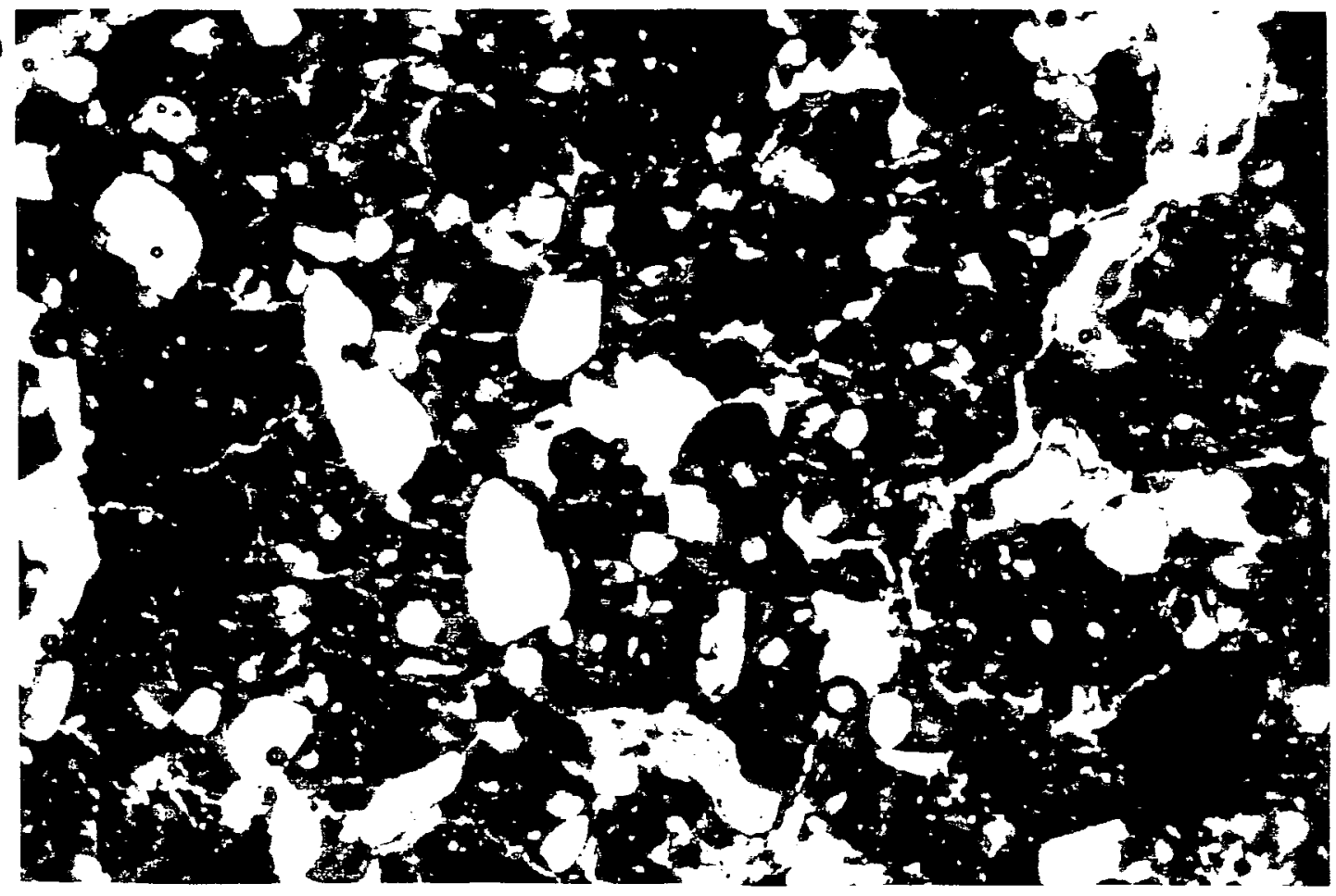

b)

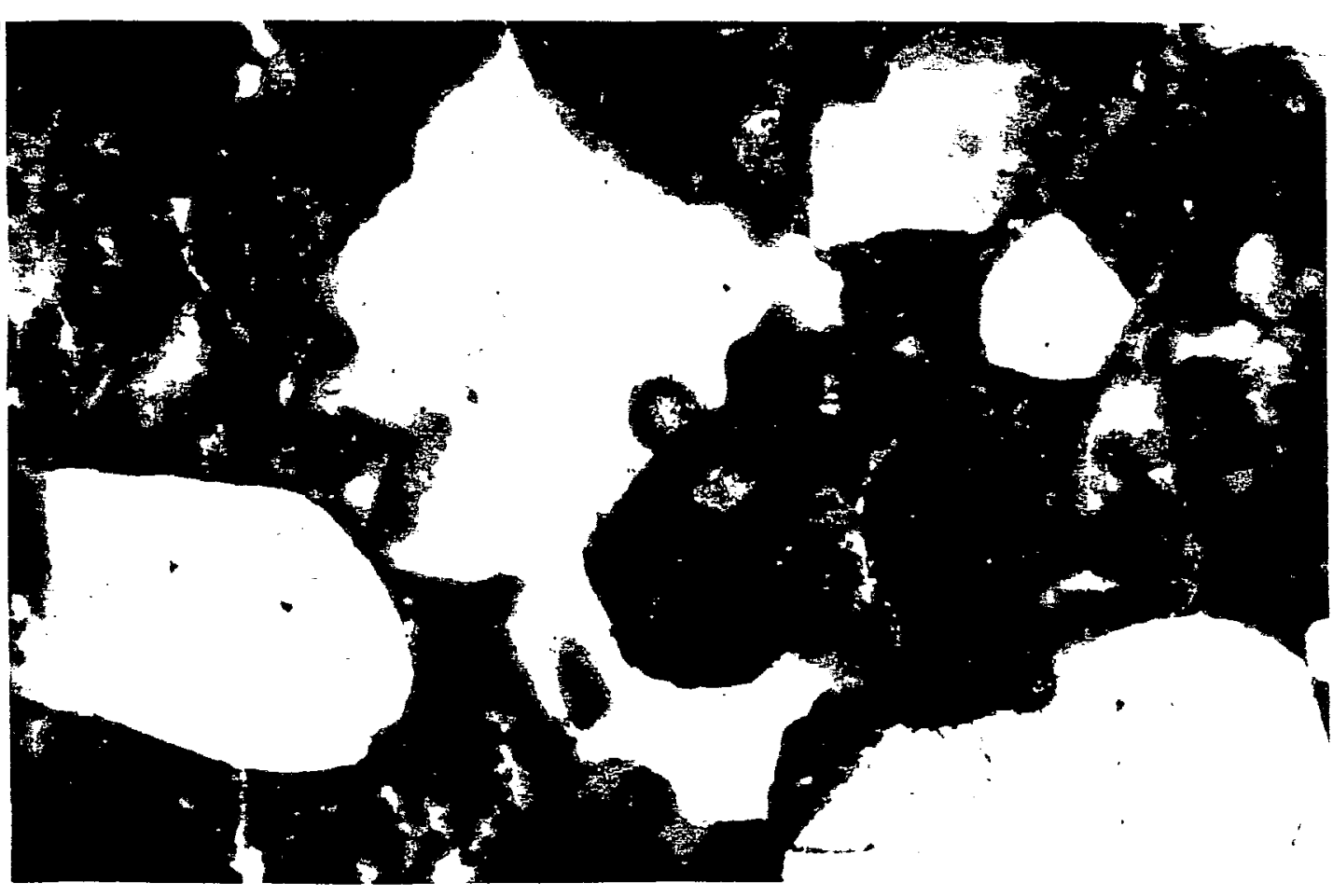

Figura 30: a) Horizonte Bt2, perfil 1. Trama porfírica fissurada mostrando a porosidade policôncava característica da coalescêmcia de microagregados.(28x) b) Detalhe da porosidade policôncava.(138x) 
a)

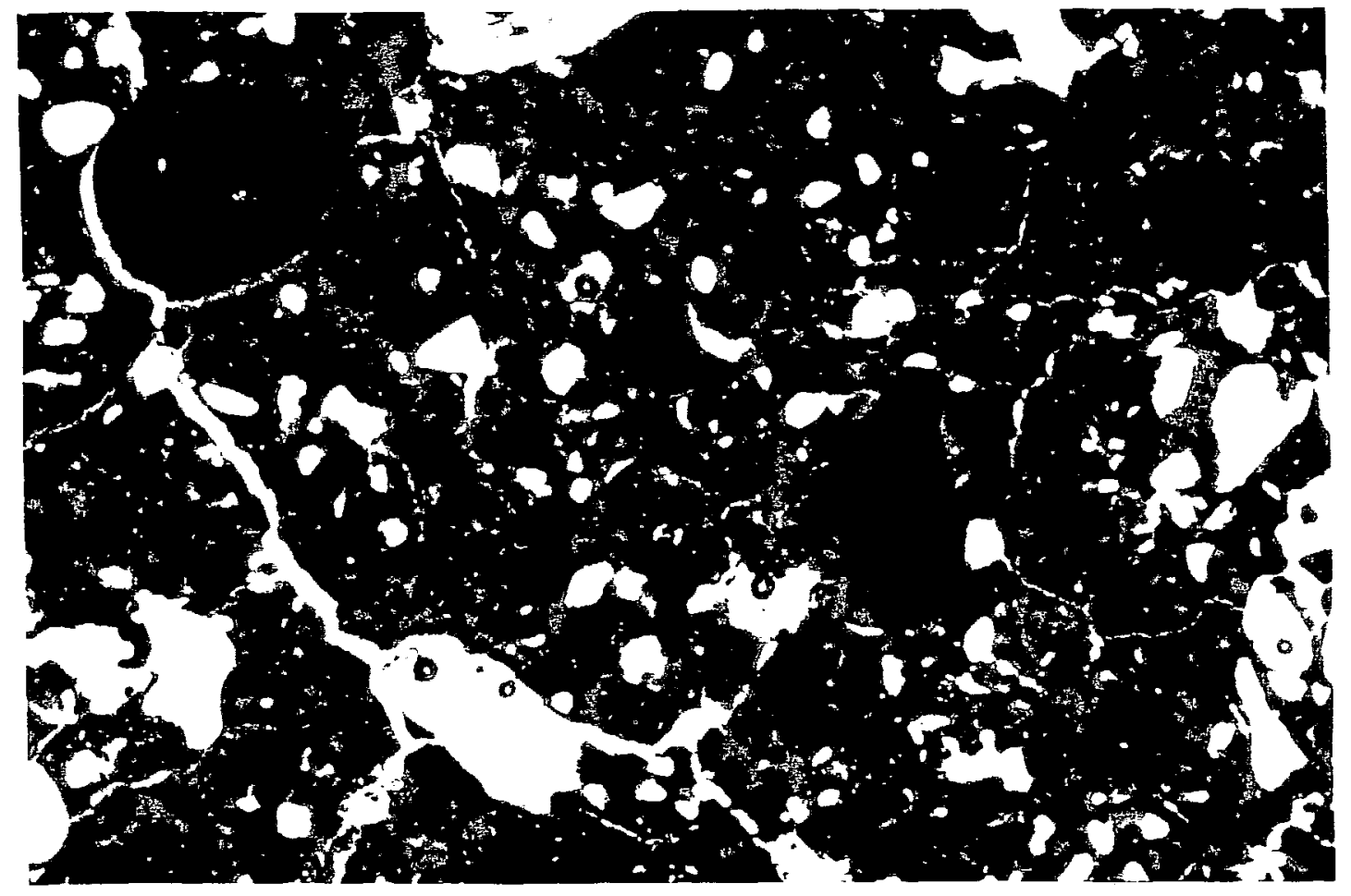

b)

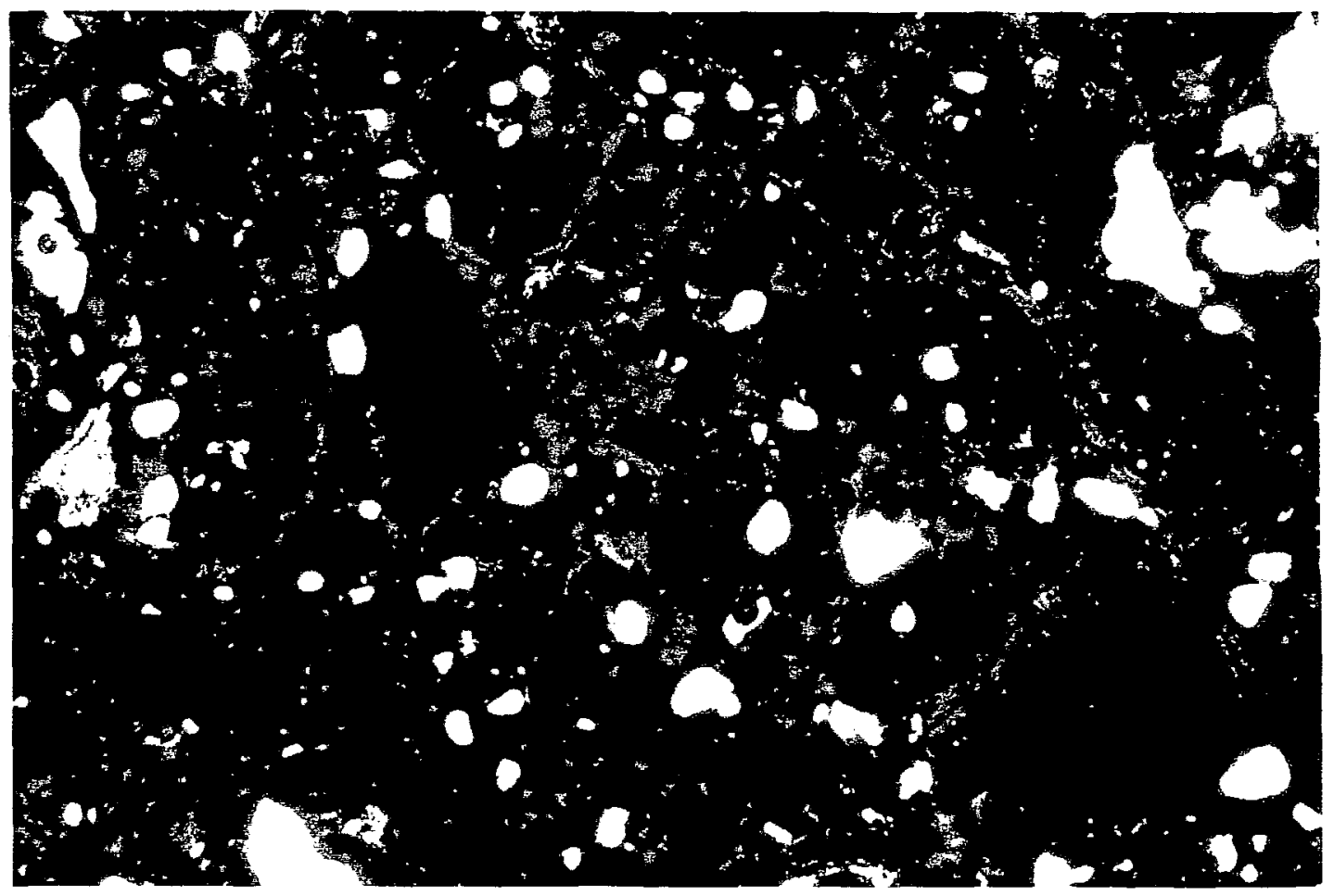

Figura 31: a) Fotomicrografia sob luz polarizada em un plano. Trama porfírica com cavidades de ocorrência comum de ferriargilãs de iluviação coalescendo os microagregados.(28x) b) Idem com nícois cruzados.(28x) 


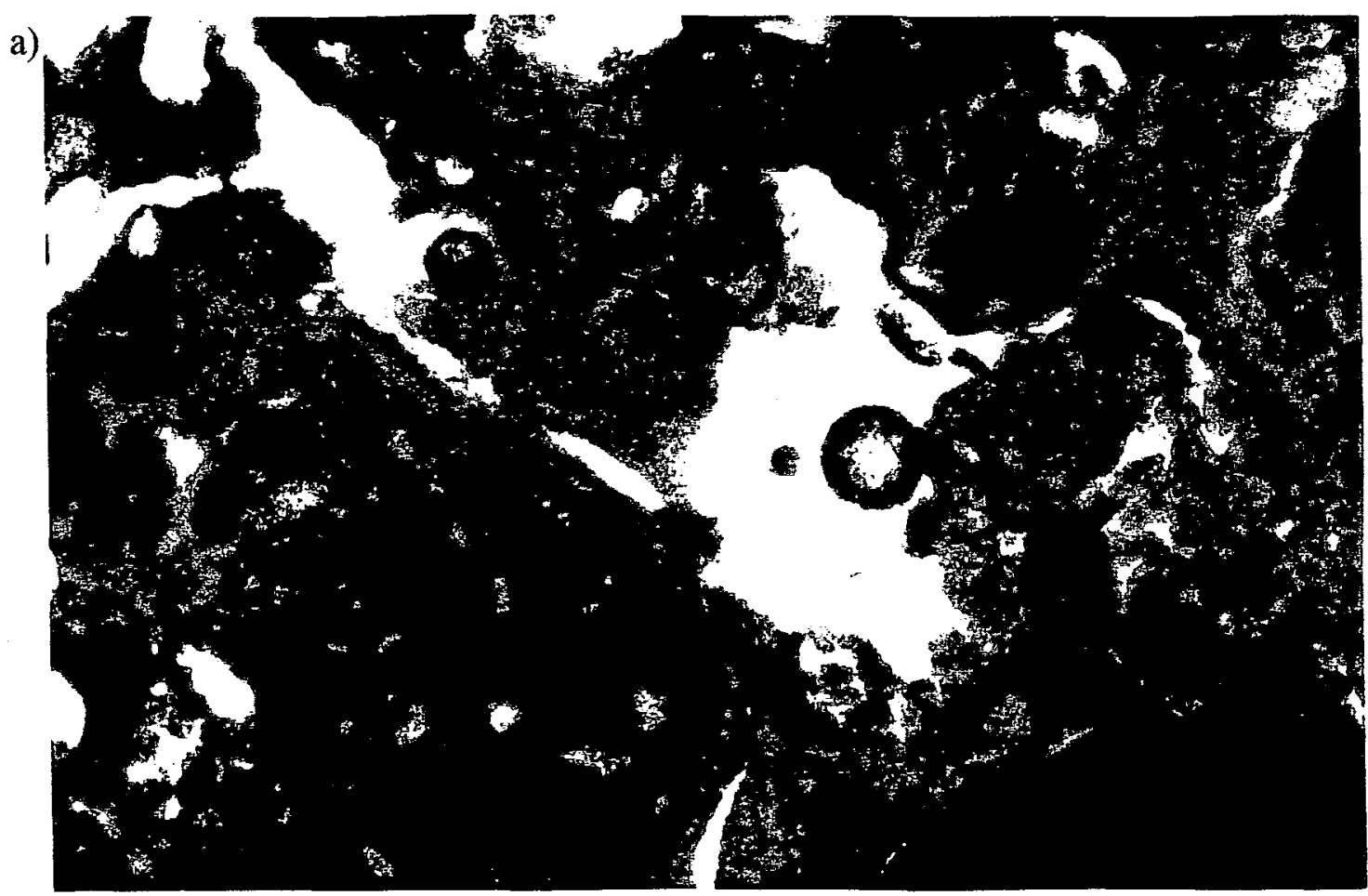

b)

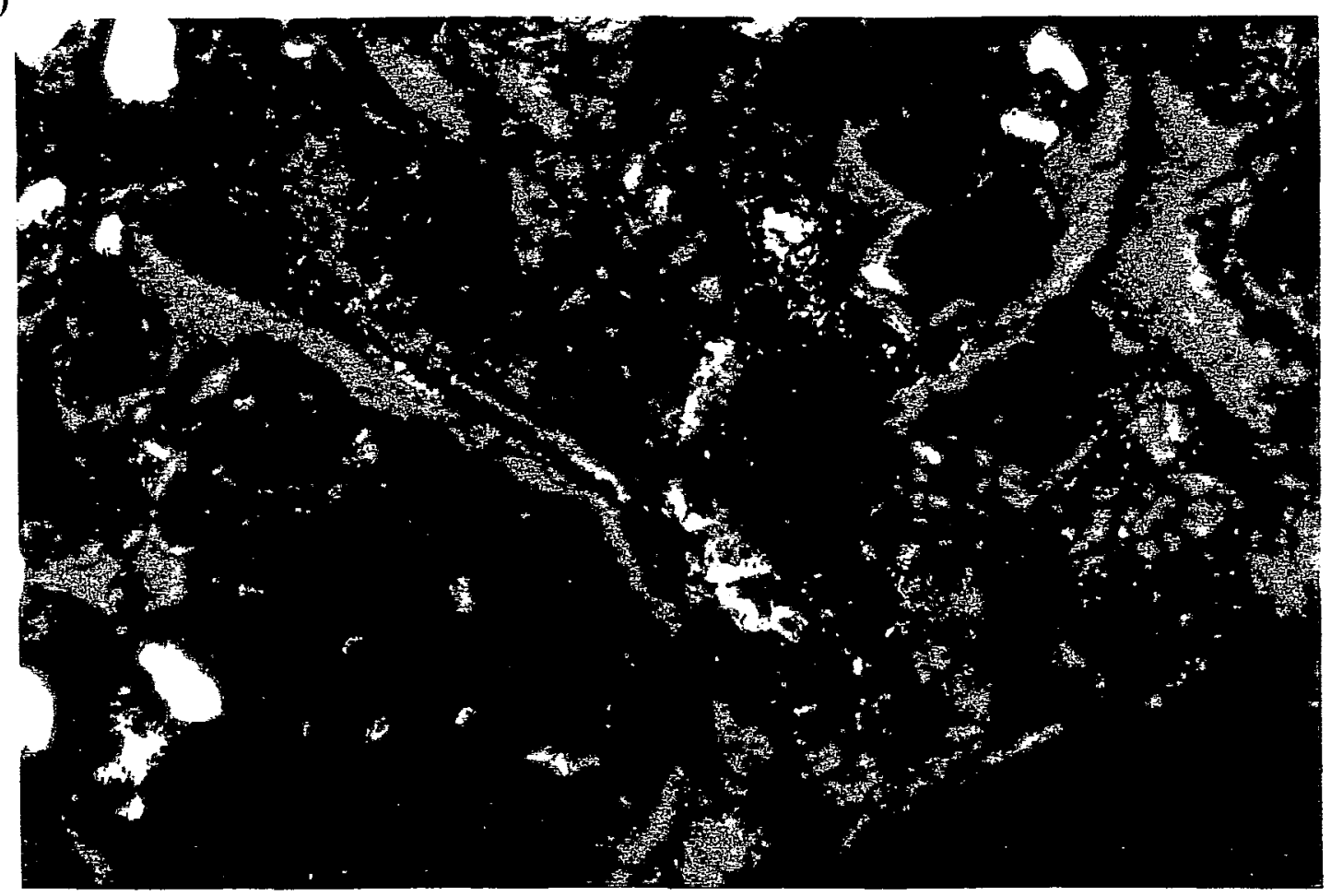

Figura 32: a) Fotomicrografia sob luz polarizada em um plano. Detalhe da figura anterior mostrando cavidades com ocorrência de ferriargilãs de iluviação e coalescendo microagregados (138x). b) Idem com nícois cruzados (138x). 


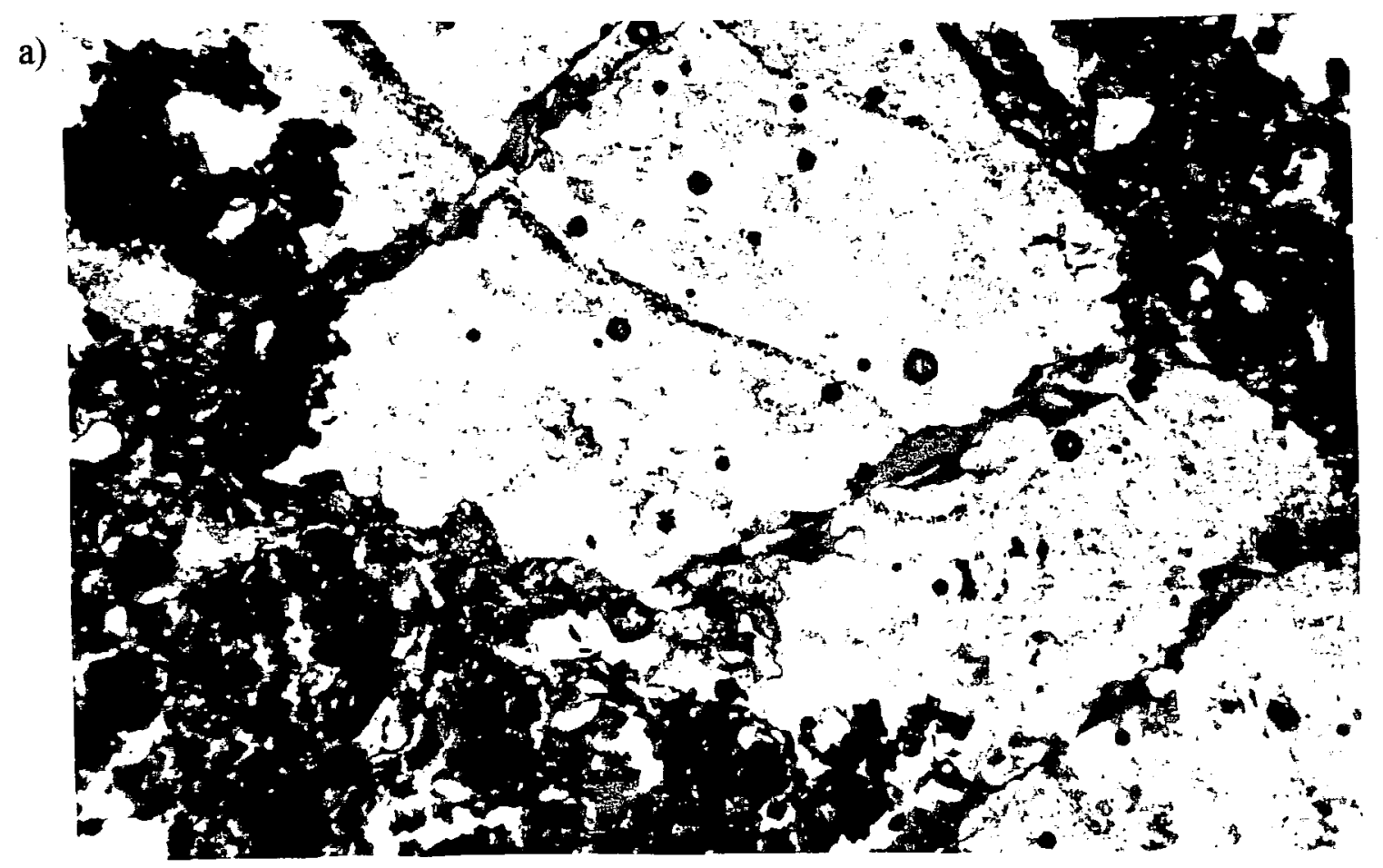

b)

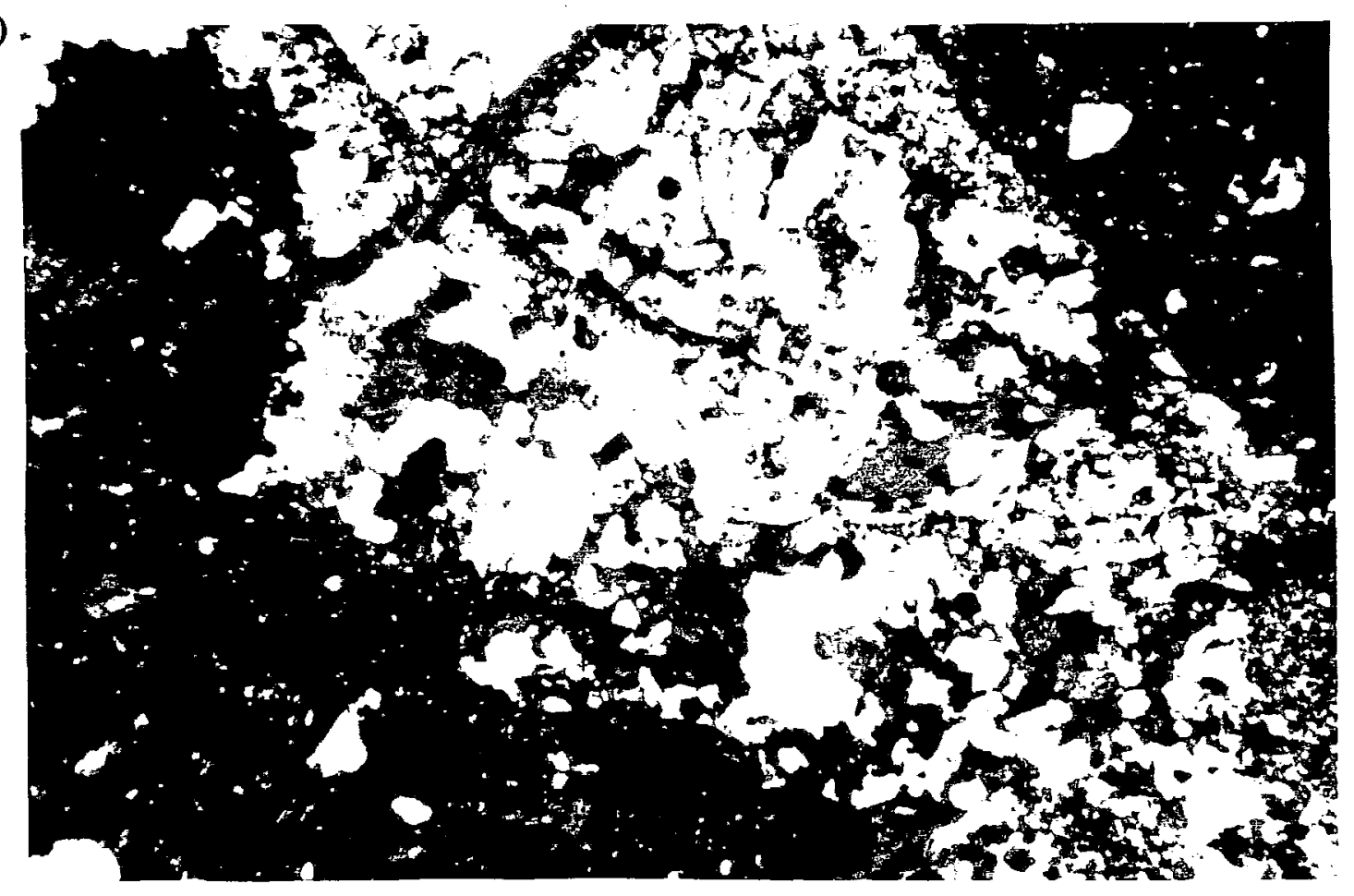

Figura 33: a) Fotomicrografia sob luz polarizada em um plano. Horizonte C, perfil1 (P1). Quartzito com ferriargilãs e mangãs situado próximo à linha de pedras (28x). b) Idem com nícois cruzados $(28 \mathrm{x})$. 


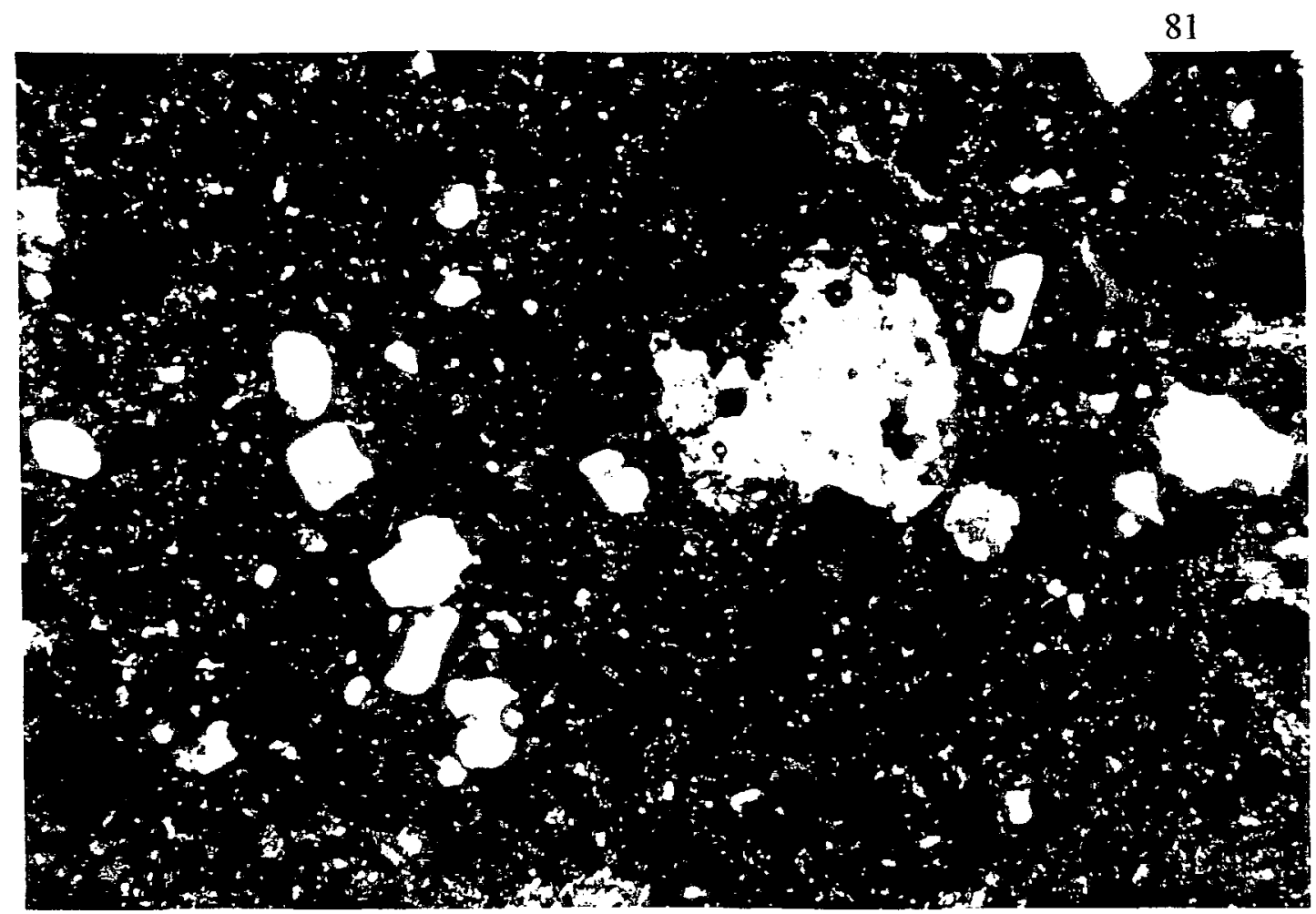

Figura 34: Fotomicrografia com nícois cruzados. Alterita, perfill. Grãos de quartzo com grau variável de esfericidade. Agregado microcristalino de quartzo formados por cristalizaçao a partir de solução. Nódulos ferruginosos em formação por segregação de $\mathrm{Fe} .(28 \mathrm{x})$

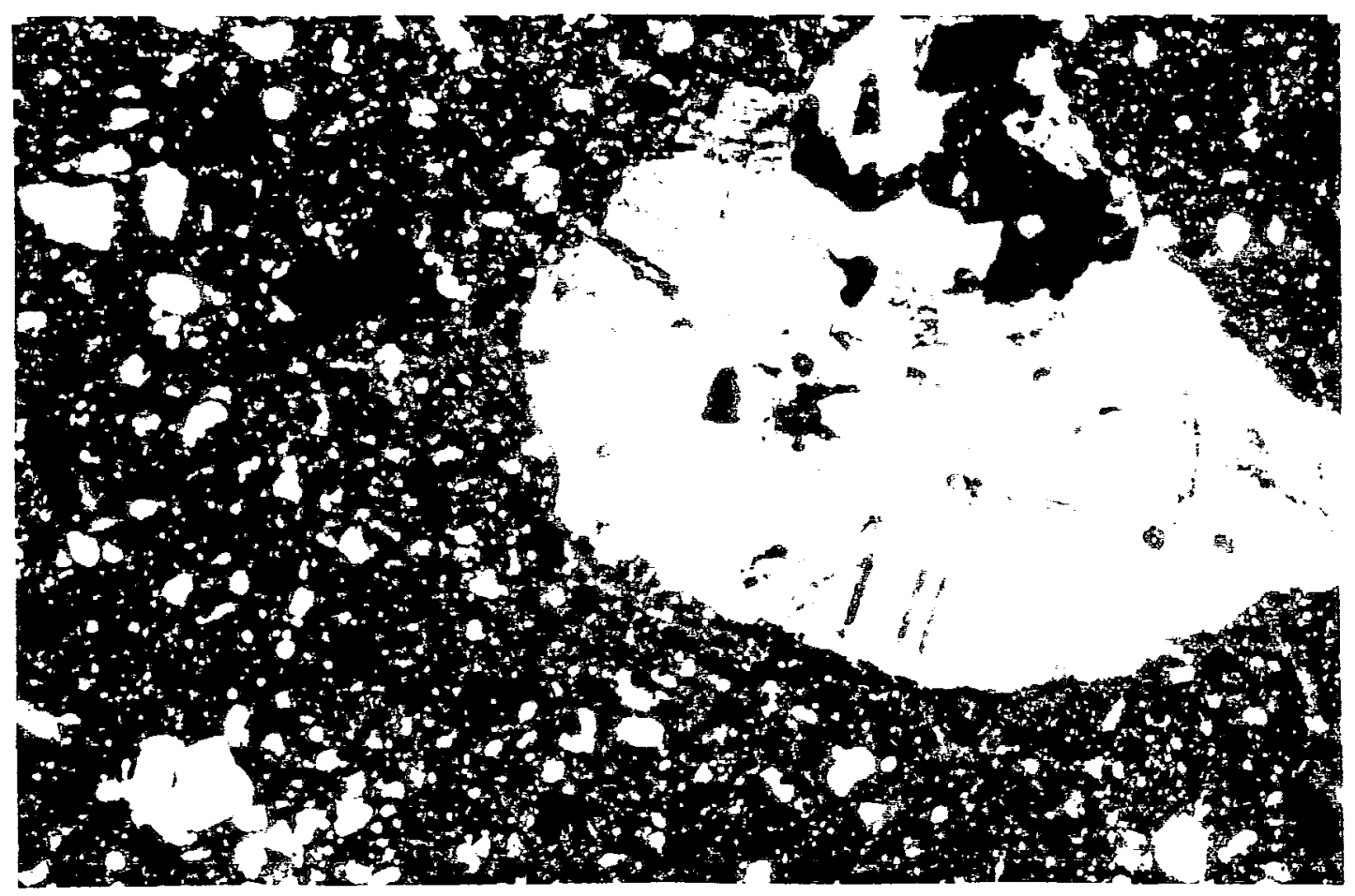

Figura 35: Horizonte Btl, perfil 4. Fundo matricial com grande quantidade de material intemperizável de diabásio. Presença de fragmento de diabásio.(28x) 


\subsection{1) Origem da estrutura microagregada.}

A estrutura microagregada é característica dos horizontes $\mathrm{B}$ latossólicos $(\mathrm{Bw})$ e resulta de um empilhamento de microagregados e grãos de quartzo. A gênese dos microagregados pode-se considerar complexa devido à existência de diversas hipóteses que explicariam a formação destes, conforme já exposto.Dois tipos principais de microagregados foram descritos: a) microagregados ovais e microagregados poliédricos. Estes dois tipos de microagregados aparecem praticamente na mesma proporção nos horizontes Bw estudados (Figura 23).

Dentro dos microagregados ovais observaram-se dois tipos, aqueles que apresentavam esqueleto triado e aqueles que não o apresentavam (Figura 23). Miklós (1992) apresentou cinco características morfológicas para a classificação dos microagregados ovaiscomo de origem biológica. Entre estas estavam a forma oval do microagregado, o tamanho entre 100 e 1000um, a presença de neostrians na periferia dos microagregados, de microagregados de cores diferentes e de esqueleto triado no interior dos mesmos. Dentre estas, três características foram observadas em alguns dos microagregados estudados classificados como de origem biológica. Estas eram a forma oval do microagregado, o tamanho (100 a 1000um) e a presença de esqueleto triado no interior dos mesmos (Figura 24 e 26).

A explicação dada para atribuir a origem biológica a estes microagregados é que a mesofauna do solo (formigas, cupins, etc.) fabricaria com as suas mandíbulas os microagregados conferindo-lhes $\mathrm{o}$ formato oval ou circular sendo posteriormente transportados para a construção de seus ninhos ou utilizados para fechar canais e pedotúbulos. Esta fabricação de microagregados com as mandíbulas provocaria a trituração do quartzo assim como a formação de neostrians como relatado por Eschenbrenner (1986) e Miklós (1992) que chamaram a este processo de bioagregação. A presença de neostrians não foi constatada nos microagregados ovais com esqueleto triado estudados nesta área podendo isto ser explicado pelo mascaramento das estruturas plásmicas pelo ferro (opacidade). 
Os microagregados ovais sem esqueleto triado que foram observados nas descrições micromorfológicas não atendem aos requisitos para justificar a origem biológica (Figura 23). Vários trabalhos apresentam diferentes hipóteses sobre a formação destes microagregados, seja por um simples rearranjamento do plasma (Muller, 1977) ou por evolução geoquímica geralmente explicando-se a formação destes através de interações fisico-químicas entre o ferro e a caulinita (Pedro et al,. 1976; Chauvel et al., 1978; Cambier, 1986; Pedro, 1987; Dexter, 1988; Santos et al., 1989). A presença de uma mineralogia caulinítica predominante neste segmento da topossequência assim como os altos teores de ferro encontrados nestes solos (Figura 10) sugeririam que estes microagregados ovais sem esqueleto triado poderiam se formar por evolução geoquímica a partir destes minerais. Estudos geoquímicos e morfológicos mais detalhados como a utilização de técnicas de submicroscopia deverão ser feitos no futuro para esclarecer esta questão.

O terceiro tipo de microagregado observado foram os microagregados poliédricos que seriam formados a partir de processos de fissuração da trama do material de origem argiloso (Figura 27). Esta fissuração, evidente nas descrições micromorfológicas, seria o resultado de processos de expansão e contração do material devido a ciclos alternados de umedecimento e dessecação. Como observado por Beadou (1972) e Beadou et al. (1977), a intensa fissuração sofrida pelo plasma nos horizontes estudados formava os microagregados destes solos, e a porosidade fissural observada quando os microagregados eram formados se transformava em porosidade de empilhamento. Trapnell \& Webster (1986) observaram o mesmo processo de formação de microagregados poliédricos chamando-os de fragmentários. Um outro mecanismo de formação de microagregados poliédricos descrito por Miklós (1992), seria a formação de microfissuras não concordantes e de pequenas cavidades irregulares que resultariam principalmente de fenômenos que provocariam a dissolução de minerais.

De acordo com o sugerido por Buol \& Eswaran (1978), Stoops (1983), Stoops \& Buol (1985) e Vidal Torrado (1994), constatou-se que os microagregados que formam os horizontes $\mathrm{Bw}$ deste estudo apresentam formas variadas e a origem destes é complexa resultado da intervenção de mais de um processo de formação (Figura 23). 


\subsection{2) Origem da transição $\mathrm{Bt} / \mathrm{Bw}$.}

A passagem lateral, observada na Figura 66, entre uma Terra Roxa Estruturada Latossólica no topo para uma Terra Roxa Estruturada no ombro evidenciou uma transformação estrutural, tanto no sentido vertical como lateral, entre um horizonte microagregado $(\mathrm{Bw})$ que apresenta uma trama enáulica e um horizonte com estrutura poliédrica (Bt) e trama porfírica. Pode-se caracterizar esta transição lateral como sendo muito progressiva, onde o horizonte adensado poliédrico se sobrepõe ao horizonte microagregado e a transição vertical entre estes é difusa.

As análises morfológicas de campo assim como as micromorfológicas auxiliaram na determinação do sentido da transformação e na interpretação dos mecanismos e processos que deram origem a esta transformação estrutural entre estes horizontes. O sentido da transformação pode ser demonstrado pelo estudo da evolução estrutural baseado na morfologia da porosidade e da estrutura resultante da diferenciação do espaço poroso.

Para entender a evolução estrutural sugeriram-se quatro estágios semelhantes aos descritos por Miklós (1992). O primeiro estágio corresponderia à estrutura microagregada, caracterizada por apresentar uma porosidade de empilhamento e uma trama enáulica (Figura 23). O segundo estágio corresponderia a uma transição onde predomina uma trama pórfiroenáulica caracterizada pelo aparecimento de ortocavidades mamelonares resultante da coalescência dos microagregados ovais e poliédricos e uma redução do espaço poroso (Figura 22). O terceiro estágio caracteriza-se por apresentar uma trama porfírica e uma redução drástica do espaço poroso, onde a porosidade predominante é a ortocavitária e ortocavitária mamelonar (Figura 30). O quarto estágio corresponde à presença de agregados poliédricos com trama porfírica e a uma porosidade predominantemente composta por fissuras e ortocavidades mamelonares (Figura 29).

A identificação destes quatro estágios nos estudos micromorfológicos mostraria que a passagem de uma trama enáulica com porosidade de empilhamento e densidades do solo entorno de $1,25 \mathrm{~g} / \mathrm{cm}^{3}$ para uma trama porfírica com porosidade ortocavitária e ortocavitária mamelonar e densidades do solo entorno de $1,45 \mathrm{~g} / \mathrm{cm}^{3}$, seria ocasionada por uma 
compactação mecânica dos diferentes tipos de microagregados resultando na coalescência dos mesmos e provocando a redução do espaço poroso. Concomitante a este processo ocorre uma iluviação de argila que preenche o espaço poroso entre os microagregados resultando na sua cimentação (Figura 31 e Figura 32). Entretanto, este último processo não seria suficientemente importante para provocar por si só esta transformação estrutural predominando nesta a coalescência dos microagregados por compactação mecânica.

As evidências mostram que a argiluviação não é o processo principal que leva à transformação entre estes horizontes. A distribuição heterogênea dos ferriargilãs e a pouca área que ocupam em relação à àrea total estudada, mostrariam que a formação do horizonte adensado seria predominantemente resultado da coalescência dos microagregados e a argiluviação seria um processo coadjuvante que acompanharia e influenciaria secundariamente esta diferenciação estrutural.

$\mathrm{O}$ desenvolvimento de macroagregados poliédricos e da porosidade fissural interagregados, característicos do quarto estágio, ocorreria como resultado do processo de fissuração do fundo matricial porfírico. Uma intensificação deste processo seria responsável pela formação dos microagregados poliédricos observados nas transições entre os horizontes adensados e Bw.

Observou-se que os ferriargilãs localizavam-se nos poros cavitários, na porosidade de empilhamento cimentando os microagregados e dentro dos poros fissurais; alguns apresentavam-se fissurados e pedoperturbados (Figura 31 e Figura 32).

Os estudos micromorfológicos mostraram também a presença de porosidade cavitária mamelonar e de zonas de fraqueza dentro dos macroagregados poliédricos (Figura 30). Estes fatos evidenciariam que, cronologicamente, a coalescência de microagregados por compactação mecânica formando o horizonte adensado ocorreria em primeiro lugar, seguido pela fase de fissuração e formação de agregados poliédricos enquanto que o processo de iluviacão ocorreria durante estas duas fases. Esta cronologia se correlacionaria com à apresentada por Miklós (1992) no que se refere à ocorrência do adensamento antes da fissuração, mas não se correlaciona quando este autor classifica cronologicamente os argilãs como sendo posteriores ao adensamento e anteriores à fissuração, não ocorrendo a 
argiluviação durante estes processos. Fedoroff \& Eswaran (1985) também mostraram uma cronologia semelhante em que a formação de um Bt partiria de uma compactação dos microagregados de um horizonte $\mathrm{Bw}$ ocorrendo posteriormente a deposição de argilãs cobrindo os agregados e preenchendo a porosidade de empilhamento.

O mecanismo que explicaria a passagem de um horizonte microagregado para outro adensado pela coalescência de microagregados, seria a alternância entre condições climáticas pretéritas muito secas e úmidas. Esta situação se daria durante um paleoclima mais seco, provavelmente ústico ou semiárido, que levaria à formação de um meio energeticamente contrastante devido à existência de estações muito distintas como sugerido por Miklós (1992). A existência de um meio contrastante energeticamente provocaria o aparecimento de forças de tensão muito elevadas na matriz do solo com $\mathrm{pF}$ variando de 0 a 6 ao longo do ano que, segundo Pedro (1987), levariam à aproximação e coalescência dos microagregados.Devido à alternância sazonal destes períodos que provocariam o aparecimento de forças de cisalhamento que resultariam na formação de uma estrutura macroagregada.

Corroborando com o observado nas análises micromorfológicas, este autor concluiu que estes fenômenos de alternâncias sazonais muito contrastantes seriam responsáveis pela transformação estrutural de Oxissois cauliníticos em Ultissois cauliníticos.

O fato de que a deposição de argilãs ocorreu em todas as fases da formação deste horizonte $\mathrm{Bt}$, sugere que estes se originaram por diferentes mecanismos dependendo da fase pedogenética em que se encontrava o solo.

Durante a fase de coalescência dos microagregados reinavam condições climáticas mais secas, estas condições favoreceriam a ocorrência do fenômeno de ultradessecação descrito por Chauvel \& Pedro (1978), no qual ocorreria uma dissociação da água na interface das argilas ferritizadas, a redução do ferro em meio muito ácido, desestabilização das ligações ferro-argila e a liberação da argila para movimentar-se. A argiluviação nesta fase ocorreria durante os curtos períodos úmidos, e a argila transportada se depositaria na porosidade de empilhamento cimentando os microagregados que não foram coalescidos e na porosidade cavitária mamelonar em formação ou já formada. Posteriormente, a passagem 
para um clima úmido e como consequência da redução do espaço poroso ocorrida durante a fase de adensamento, provocaria um hidromorfismo temporário que promoveria à remoção do ferro, evidenciada pela identificação de cutãs de difusão, neocutãs, quasicutãs e nódulos ferruginosos, facilitando assim a mobilização da argila e sua deposição nas fissuras e na porosidade dominante (Lepsch et al.,1977b; Queiroz Neto et al., 1981; Vidal Torrado, 1994).

A fissuração do material adensado resultando na formação de agregados e microagregados poliédricos, estaria ligada a uma dinâmica da água mais atual. Esta se formaria por alternâncias sazonais em condições de clima úmido onde os contrastes energéticos são menores provocando a retração do material e a consequente fissuração (Pedro, 1987; Miklós, 1992). Não existiria nesta fase suficiente energia para aproximar e coalescer os microagregados resultando então numa fase de desestruturação do horizonte adensado.

No final do ombro e começo da meia encosta não foi evidenciado o processo de adensamento, a porosidade ortocavitária mamelonar desaparece e não são observadas as áreas de fraqueza que delimitariam os microagregados coalescidos. O perfil estudado é menos profundo e as observações micromorfológicas mostraram a presença de muito material derivado do diabásio em processo de intemperização assim como a presença de alguns ferriargilãs (Figura 3535). A formação do horizonte Bt nesta posição, não estaria ligada à dinâmica do topo e sim a uma dinâmica própria e mais recente, onde os argilominerais estariam se formando in situ sendo derivados diretamente da alteroplasmação do material alterado do diabásio como citado por Birkeland (1984) e Fedoroff \& Eswaran (1985). A observação de processos de migração de ferro (descoloração do plasma, halos, quasicutãs) evidenciariam que estaria havendo um rompimento das ligações entre o ferro e as argilas, resultando na liberação destes últimos favorecendo a sua mobilidade e a sua consequente deposição na forma de argilãs (Lepsch et al., 1977b; Queiroz Neto et al., 1981, Vidal Torrado, 1994).

Uma particularidade observada no perfil 1 (P1) (Figura 21) foi a formação de um horizonte adensado no meio de dois horizontes $\mathrm{Bw}$. A origem deste horizonte é incerta mas poderia ter se originado por uma deposição de um coluvio mais argiloso, durante o segundo 
evento de deposição, proveniente de uma alternância rápida para uma fase úmida entre dois períodos de climas secos. A diferença observada no tamanho e grau de seleção do quartzo assim como no tamanho e classe de microagregados entre os horizontes Bwl e Bw2, evidencia que estes horizontes seriam formados por materiais semelhantes que provavelmente foram depositados em momentos distintos. Observou-se que o horizonte Bw1 apresentou um tamanho maior e um grau de seleção pior do quartzo em relação ao horizonte Bw2. Predominavam no horizonte Bw1 os microagregados poliédricos enquanto que no Bw2 predominavam os ovais, estes de tamanho menor que os do Bw1. A fragmentação posterior por fissuração e atividade biológica, deste paleohorizonte, teria resultado na formação do horizonte Bwl (Figura 27 e 29). Este processo seria evidenciado pelos domínios adensados encontrados dentro do fundo matricial que apresentam características morfológicas muito similares aos apresentados pelo horizonte Bt3, e pela intensa fissuração que está sofrendo o horizonte Bt3 provocando a desestruturação deste e a formação de microagregados poliédricos na transição com o horizonte Bw1. 


\section{CONCLUSÕES}

1) A origem dos depósitos arenosos finos do topo plano mais elevado correlacionase com a formação do pediplano Pd1 descrito por Penteado (1968). Estes foram depositados, na forma de alveolos escalonados, durante a fase semi-árida, que se correlaciona com o período glacial Danube, onde as soleiras regionais, formadas pelos sills e diques de diabásio expostos durante a escavação da Depressão Periférica, atuaram como barreiras tectônicas para os materiais arenosos que tinham sido erodidos e transportados de posições à montante dominados por afloramentos da formação Pirambóia (TrJp).

2) A ocorrência de um segundo evento deposicional correlaciona-se com o entalhamento do pediplano Pd1 e uma pedimentação posterior formando o nível pedimentar P2. Esta pedimentação foi atribuída ao período de semiaridez do glacial Gunz, que expos o sill de diabásio e parte da formação Irati sendo posteriormente entulhado, devido a um processo de agradação, por material argiloso originário do próprio sill de diabásio, com contribuição de areia fina e média do material arenoso fino depositado durante a primeiro evento deposicional.

3) O caráter alóctone de duas "stonelines", uma no contato entre o depósito arenoso fino e a formação Irati e outra mais elevada entre o depósito argiloso e a alterita de diabásio e uma pequena porção da formação Irati, ficou comprovado ao evidenciar a presença de duas descontinuidades litológicas entre estes materiais. Estas "stonelines" teriam conformado dois paleopavimentos detríticos diferentes, correspondentes a duas fases semi-áridas distintas, que se correlacionam com a deposição dos materiais arenosos finos e argilosos. O material fonte para a formação destas "stonelines", seria, no caso da primeira"stoneline", os arenitos 
conglomeráticos da formação Pirambóia e , no caso da segunda, seixos que se encontravam esparsos dentro do depósito arenoso que ao sofrer o processo de pedimentação foram transportados e depositados em posições à jusante.

4) A participação de mais de um processo na formação dos microagregados determinou a origem complexa destes. A formação de microagregados ovais com esqueleto triado, ovais sem esqueleto triado e poliédricos são o produto final de diferentes processos de formação. As evidências micromorfológicas mostraram que a ação mecânica da mesofauna, na sua escavação do solo, resultou na formação dos microagregados ovais com esqueleto triado. Processos geoquímicos foram sugeridos para a formação dos microagregados ovais sem esqueleto triado e a fissuração do fundo matricial resultou na formação dos microagregados poliêdricos.

5) A morfologia do espaço poroso mostrou que a evolução estrutural de um horizonte $\mathrm{Bw}$ para um $\mathrm{Bt}$ parece ser devida a um adensamento do horizonte $\mathrm{Bw}$, pela coalescência dos microagregados durante um período de clima mais seco que o atual, que provocaria a aparição de tensões devido à existência de estações muito distintas levando à formação de um meio energeticamente contrastante. A passagem posterior para um clima úmido, porém com estação seca definida, provocaria ciclos alternados de umedecimento e dessecação mais frequentes que resultam na fissuração do material e a formação de agregados e microagregados poliédricos. Concomitantemente a estes processos, a argiluviação estaria presente, provocando a cimentação dos microagregados e preenchendo o espaço poroso. Esta se originaria por dois processos diferentes, um durante o clima semiárido pelo fenômeno de ultradessecação e outro durante o clima úmido pela liberação e transporte da argila devido a processos localizados de hidromorfia temporária, que levaria à remoção do ferro provocando o rompimento das ligações argila-ferro, promovendo a argiluviação. 


\section{REFERÊNCIAS BIBLIOGRÁFICAS}

AB'SABER, A.N. Revisão dos conhecimentos sobre o horizonte subsuperficial de cascalhos inhumados do Brasil Oriental. Notícia Geomorfológica, Ano IV, 11, p. 59-80. 1966.

AB'SABER, A.N. A Depressão Periférica Paulista: um setor de circundesnudação póscretácica na Bacia do Paraná. Universidade de São Paulo, Instituo de Geografia, São Paulo. Geomorfologia, 15. 1969. 15p.

BEADOU, A. Expression micromorphologique de la microagrégation et de l'illuviation dans certains sols ferralitiques centraficans et dans les sols hydromorphes associés. Cahiers ORSTOM, Séries Pédologie, 10 (4):357-371. 1972.

BEADOU, A.; CHATELIN, Y; COLlINET, J. \& SALA, G.H. Notes sur la micromorphologie de certains sols ferralitiques jaunes de régions équatoriels d'Afrique. Cahiers ORSTOM, Séries Pédologie, 4:357-379. 1977.

BEADOU, A.; FROMAGET, M. \& GUICHARD,E. Analyse des organisations micro et macrostructurales de certains sols ferralitiques centrafricains issus de roches basiques. ACTES DE LA VII RÉUNION INTERNATIONALE DE MICROMORPHOLOGIE DES SOLS. Paris. Edité par N. Fedoroff et L.M. Bresson. p.119-124. 1987. 
BEAUVAIS, A. \& TARDY, Y. Formation et dégradation des cuirasses ferrugineuses sous climat tropical humide, à la lisiére de la forêt équatoriale. C.R. Academie Science Paris, t.313, série II, p.1539-1545. 1991.

BIGARELLA, J.J.; MOUSINHO, M.R. \& DA SILVA, J.X. Pediplanos, Pedimentos e seus Depósitos correlativos no Brasil. Boletim Paranaense de Geografia, 16 e 17:117-151. 1965.

BIGARELLA, J.J. \& MOUSINHO, M.R. Contribuição ao estudo da formação Pariquera-Açu (estado de São Paulo). Boletim Paranaense de Geografia, 16 e 17:17-41. 1965a.

BIGARELLA, J.J. \& MOUSINHO, M.R. Considerações a respeito dos terraços fluviais, rampas de colúvio e várzeas. Boletim Paranaense de Geografia, 16 e 17:153-197. $1965 b$.

BIRKELAND, P.W. Soils and Geomorphology. Oxford University Press, New York, 1984. 372p.

BIRKELAND, P.W., MACHETTE, M.N., HALLER, K.H. Soils as a tool for applied quaternary geology.Utah Geological and Mineral Survey, 1990. 63p.

BJORNBERG, A.J.S. \& LANDIM, P.M.B. Contribuição ao estudo da formação Rio Claro, neocenozoico. Boletim da Sociedade Brasileira de Geologia, 15 (4): 43-68. 1966.

BOULET, R. Análise estrutural da cobertura pedológica e cartografia. In: XXI CONGRESSO BRASILEIRO DE CIÊNCIA DO SOLO, Campinas, julho 1987. A 
Responsabilidade Social da Ciência do Solo, Sociedade Brasileira de Ciência do Solo, Campinas. p.79-90. 1988.

BOULET, R.; CHAUVEL, A.; HUMBEL, F.X. \& LUCAS, Y. Analyse structurale et cartographie em pédologie. Cahiers ORSTOM Séries Pédologie, vol. XIX, $n^{\circ} 4$ : 309-351. 1982.

BREWER, R. Fabric and Mineral Analysis of Soils. Robert E. Krieger Publishing Company. Huntington, New York, 1976. 482p.

BRINKMAN, R. Ferrolysis, a hydromorphic soil forming process. Geoderma, 3:199206. 1970.

BULLOCK, P.; FEDOROFF, N.; JONGERIUS, A.; STOOPS, G. \& TURSINA,T. Handbook for soil thin section description. Waine Research, Albrington, UK, 1985. 152p.

BULLOCK, P. \& THOMPSON, M.L. Micromorphology of Alfisols. In: SOIL MICROMORPHOLOGY AND SOIL CLASSIFICATION, Anaheim, 1985. Proceedings of a symposium sponsored by Divisions S-5 and S-9 of the Soil Science Society of America, Anaheim. ed. L.A. Douglas and M.L. Thompson, SSSA, Madison. p.17-47. 1985.

BUOL, S.W. \& ESWARAN, H. The micromorphology of oxisols. Proceedings Vth International Workshop Meeting Soil Micromorphology, Granada, M. Delgado ed., vol. 1:325-347. 1978. 
BUOL, S.W.; HOLE, F.D.; McCRAKEN, R.J. Soil genesis and classification. The Iowa State University Press, Ames. 1980. 404p.

CAMARGO, O.A. de, MONIZ, A.C., JORGE, J.A. \& VALADARES, J.M.A.S. Métodos de análise química, mineralógica e física de solos do Instituto Agronômico de Campinas. Campinas, Instituto Agronômico, 1986. 94p. (Boletim técnico 106).

CARVALHO, A.; CHAUVEL, A. \& GONÇALVES, N.M.M. Alteration of basalt and formation of kaolinic and gibbsitic material in the region of Ribeirão Preto (SP), Brazil. In: LATERISATION PROCESS. Proceedings II International Seminar on Laterization Processes, São Paulo. p. 477-489. 1982.

CASTRO, S.S. Impregnação de amostras de solos para confecção de lâminas delgadas. Boletim Informativo da Sociedade Brasileira de Ciência do Solo, 10 (2):44, 1985.

CASTRO, S.S. Sistemas de transformação pedológica em Marília, SP: B latossólicos e B texturais. São Paulo, Faculdade de Filosofia, Letras e Ciências Humanas da Universidade de São Paulo, 1989. 274p. (Tese de Doutoramento).

CHAPMAN, S.L. \& HORN, M.E. Parent material uniformity and origin of silty soils in Northwest Arkansas based on zirconium-titanium contents. Soil Science Society of America Proceedings, 32:265-271. 1968.

CHAUVEL, A. Recherches sur la transformation des sols ferralitiques dans la zone tropicale à saisons contrastées. Thése Science Strasbourg (1976) et Travails et Documents ORSTOM, 62, 532p., 1977. 
CHAUVEL, A. \& PEDRO, G. Sur l'importance de l'extreme dessication (ultradessication) dans lévolution pédologique des zones tropicales à saisons contrastées. C.R. Academie Science, t.286:1581-1584. 1978.

CHAUVEL, G; BOCQUIER, G. \& PEDRO, G. La stabilité et la transformation de la microstructure des sols rouges ferralitiques de Casamance (Senegal). Analyse microscopique et données experimentales. In: SOIL MICROMORPHOLOGY PROCEEDINGS. $5^{\text {th }}$ INTERNATIONAL WORKSHOP MEETING ON SOIL MICROMORPHOLOGY, Universidad de Granada (Espanha). p. 779-813. 1978.

COELHO, R.M.; LEPSCH, I. F.\& MENK, J.R.F. Relações solo-relevo em uma encosta com transição arenito-basalto em Jaú (SP). Revista Brasileira de Ciência do Solo, 18:125-137, 1994.

COMISSÃO DE SOLOS Levantamento de reconhecimento dos solos do Estado de São Paulo. Serv. Nac. de Pesq. Agronômica, Comissão de Solos, Ministério da Agricultura, CNEPA. (Boletim12). 1960.

CONACHER, A.J. \& DALRYMPLE, J.B. The nine unit landsurface model: an approach to pedogeomorphic research. Geoderma, 18:1-154. 1977.

CREUTZBERG, D. \& SOMBROEK, W.G. Micromorphological characteristics of Nitosols. Actes de la VII Réunion Internationale de Micromorphologie des Sols, Paris. ed. N. Fedoroff et L.M. Bresson. p. 151-155. 1987.

CURI, N. \& FRANZMEIER, D.P. Toposequence of oxisols from the central plateau of Brazil. Soil Science Society America Journal 43:341-346. 1984. 
DEMATTÊ, J.L.I. Zircônio e Titânio da fração areia de solos. Revista Brasileira de Ciência do Solo, 2:74-77. 1978.

DEXTER, A.R. Advances in characterization of soil structure. Soil \& Tillage Research, 11:199-238. 1988.

DIJKERMAN, J.C. \& MIEDEMA, R. An Ustult-Tropept catena in Sierra Leone, West Africa, I. Characteristics, genesis and classification. Geoderma, 42:1-27. 1988.

DREES, L.R. \& WILDING, L.P. Elemental variability within a sampling unit. Soil. Science Society of America Proceedings, 37:82-87. 1973.

ESCHENBRENNER, V. Contribution des termites à la micro-agrégation des sols tropicaux. Cahiers ORSTOM, Séries Pédologie, XXII(4):397-408. 1986.

ESPEN, P.; NULLENS, H.; ADAMS, F. A. A computer analysis of X-ray fluorescence spectra. Nuclear Instruments and Methods, vol. 142, p. 243 - 250, 1977.

ESPEN, P.; JANSSENS, P.; SWENTERS, I. AXIL X-ray Analysis Software. Users Manual. Versão 3.1, Canberra Packard, Benelux, 72 pag., 1991.

ESWARAN, H. \& SYS, C. Argillic horizon in LAC soils: formation and significance to classification. Pedologie, 29:175-190. 1979.

FEDOROFF, N. \& ESWARAN, H. Micromorphology of ultisols. In: SOIL MICROMORPHOLOGY AND SOIL CLASSIFICATION. Proceedings of a symposium sponsored by Divisions S-5 and S-9 of the Soil Science Society of 
America, Anaheim. ed. L.A. Douglas and M.L. Thompson, SSSA, Madison. p.145164. 1985.

FOST, J.E. \& RUST, R.H. Soil genesis study of a lithological discontinuity in glacial drift in Western Wisconsin. Soil Science Society of America Proceedings, 32:393398. 1968.

GERRARD, J. Soils and Landform. An integration of geomorphology and pedology. Allen and Uwin puBoletim, London, 219p. 1981.

GRAHAM, R.C.; DANIELS, R.B. \& BUOL, S.W. Soil-Geomorphic relations on the Blue Ridge Front: I. Regolith types and slope processes. Soil Science Society of America Journal, 54:1362-1367. 1990.

GRAHAM, R.C. \& BUOL, S.W. Soil-Geomorphic relations on the Blue Ridge Front: II. Soil characteristics and pedogenesis. Soil Science Society of America Journal, 54:1367-1377. 1990.

HALL, G.F. Pedology and Geomorphology. In: Pedogenesis and soil taxonomy. I Concepts and interactions. Elsevier Science PuBoletim, New York, 1983. p.117140.

HONEYCUTT, C.W.; HEIL, R.D. \& COLE, C.V. Climatic and topographic of three Great Plains soils: I. Soil morphology. Soil Science Society of America Journal 54:469-475. 1990. 
IPT. Mapa geológico do Estado de São Paulo. Escala 1: 500.000. Divisão de Minas e Geologia Aplicada do Instituto de Pesquisas Tecnológicas do Estado de São Paulo. São Paulo, 1981a.

IPT. Mapa geomorfológico do Estado de São Paulo. Escala 1:1.000.000. Divisão de Minas e Geologia Aplicada do Instituto de Pesquisas Tecnológicas do Estado de São Paulo. São Paulo, 1981 b.

ISBELL, R.F. The argillic horizon concept and its application to the classification of tropical soils. In: Proceedings conference on classification of tropical soils, ed. K.T. Joseph, Kuala LumpuRevista Malasyan Society of Soil Science.p. 150-157. 1980.

JACKSON, M.L. Soil chemical analysis. Advanced course. Madison, Wisconsin. Publicado pelo autor 1969. 894p.

JENKINS, R.; DE VRIES, J. L. Quantitative analysis. In: - Practical X-Ray Spectrometry. Springer-Verlag, New York, cap. 7, p. 126 - 144, 1970 (189 pag.).

JENNY, H. Factors of soil formation. Mc Graw Hill, New York. 1941. 305 p.

1 JIMENEZ RUEDA, J. \& DEMATTÊ, J.L.I. Solos originados de lamitos da formação Marilia (Grupo Bauru) da região de Monte Alto, SP. Revista Brasileira de Ciência do Solo, 12(2):161-170. 1988.

JOHNSON, D.L. Biomantle evolution and the redistribution of earth materials and artifacts. Soil Science, 149(2):84-102. 1990. 
JOHNSON, P.R. \& BEAVERS, A.H. A mineralogical characterization of some loessderived soils in Illinois. Soil Science Society America Proceedings, 23: 143-146. 1959.

JOHNSON, D.L. \& WATSON-STEGNER, D. Evolution model of pedogenesis. Soil Science. 143(5): 349-366. 1987.

KING, L. Canons of landscape evolution. Bulletin of the Geological Society of America. 64:721-751. 1963.

KREZNOR, W.R.; OLSON, K.R.; BANWART, W.L.; JOHNSON, D.L. Soil, landscape, and erosion relationships in a Northwest Illinois Watershed. Soil Science Society America Journal 53:1763-1771. 1989.

LEMOS, R.C. DE \& SANTOS, R.D. DOS Manual de descrição e coleta de solo no campo. Campinas, SBCS/SNLCS, 46p.. 1984.

LEPSCH, I.F. \& BUOL, S.W. Investigations in an Oxisol-Ultisol toposequence in São Paulo State, Brazil. Soil Science Society America Proceedings, 38:491-496. 1975.

LEPSCH, I.F.; BUOL, S.W. \& DANIELS, R.. Soil landscape relationships in the occidental plateau of São Paulo, Brazil: II. Soil morphology, genesis and classification. Soil Science Society America Journal, 41:109-115. 1977.

LICHTE, M. Stonelines as a definite cycle feature in southeast Brazil: A geomorphological and pedological case study. Pedologie, XL-1, p. 101-109. 1990. 
LICHTE, M. Arid processes in the SE Brazilian relief evolution during the last glacial. Boletim IG-USP, Publicação Especial, 8:201-211, 1991.

LOBO, A.E.M. Relações solos-superficies fisiográficas em uma topossequência em Piracicaba, SP. Escola Superior de Agricultura "Luiz de Queiroz", USP, 1984. 164p. (Tese de Doutoramento).

LUCAS, Y.; BOULET, R. \& CHAUVEL, A. Modalité de la formation in situ de stone lines en zone equatoriale. Exemple d'une coverture ferralitique d'Amazonie au Brésil. C. R. Academie Science, t. 311, Série II, p.713-718, 1990.

LUZ, L.R.Q.P.; SANTOS, M.C.D. \& MERMUT, A.R. Pedogênese em uma topossequência do semi-arido de Pernambuco. Revista Brasileira de Ciência do Solo, 16: 95-102, 1992.

MALO, D.D.; WORCESTER, K.D.; CASSEL, D.K.; MATZDORF, K.D. SoilLandscape relationships in a closed drainage system. Soil Science Society of America Proceedings. 38:813-817. 1974.

MACFARLANE, M.J. \& POLLARD, S. Some aspects of stonelines and dissolution fronts associated with regolith and Dambo profiles in parts of Malawi and Zimbabwe. Geo-Eco-Tropicale. 11(1-4): 23-35. 1989.

MARSHALL, C.E. A petrographic method for the study of soil formation processes. Soil Science Society America Proceedings, 5:100-103. 1940. 
MARSHALL, C.E. \& HASEMAN, J.F. The quantitative evaluation of soil formation and development by heavy mineral studies: a grundy silt-loam profile. Soil Science Society America Proceedings, 7:448-453. 1942.

MARTONNE, E. de. Problemas morfológicos do Brasil tropical Atlântico. Revista Brasileira de Geografia, 4: 523-550. 1943.

MELO, M.S. A formação Rio Claro e depósitos associados: sedimentação neocenozóica na Depressão Periférica Paulista. São Paulo, Instituto de Geociências, USP. 143p. 1995. (Tesè dè Doutoramento).

MELO, M.S. \& PONÇANO, W.L. Gênese, distribuição e estratigrafia dos depósitos cenozóicos no Estado de São Paulo. IPT, São Paulo, Série Monografias, 9. 1983. $74 \mathrm{p}$.

MIKLÓS, A.A. DE W. Biodynamique d'une coverture pédologique dans la région de Botucatú, Brésil. Université de Paris VI, France. Vols. I e II, 438p. 1992. Tese de Doutoramento.

MIKLÓS, A.A. DE W. Funcionamento biodinâmico da paissagem. Ciência \& Ambiente, IV(6) Jan/Jun. p. 75-83. 1993.

MIKLÓS, A.A. DE W. Terra Roxa Estruturada: Organização de orígem holocênica. In: XXV CONGRESSO BRASILEIRO DE CIÊNCIA DO SOLO. Viçosa, julho 1995. Resumos expandidos, Sociedade Brasileira de Ciência do Solo, Campinas. p.15671570. 1995. 
MONIZ, A.C. \& BUOL, S.W. Formation of an Oxisol-Ultisol transition in São Paulo, Brazil: I - Double-water flow model of soil development. Soil Science Society of America Journal, 46: 1228-33, 1982.

" MONIZ, A.C.; BUOL, S.W. \& WEED, S.B. Formation of an Oxisol-Ultisol transition in São Paulo, Brazil: II. Lateral Dynamics of Chemical Weathering. Soil Science Society of America Journal, 46: 1234-37, 1982.

MULLER, J.P. Microestruturation des structichrons rouges ferralitiques, à l'amont des modelés convexes (Centre-Cameroun). Aspects morphologiques. Cahiers ORSTOM, Séries Ped., 15(3):239-258.1977.

MULLER, J.P. Sequence of vertical evolution in the microorganization of loose ferralitic materials in the Cameroons. In: SOIL MICROMORPHOLOGY. INTERNATIONAL WORKSHOP MEETING SOIL MICROMORPHOLOGY, Proceedings London. A.B. Academic Publishers., London, p. 1-10. 1981.

NETTLETON, W.D.; FLACH, K.W. \& BRASHER, B.R. Argillic horizons without clay skins. Soil Science Society America Proceedings 33:121-125. 1969.

OLIVEIRA, J.B.DE; ALFONSI, R.R. \& PEDRO JUNIOR, M.J. Regimes hídricos e térmicos dos solos do Estado de São Paulo. In: CONGRESSO BRASILEIRO DE CIÊNCIA DO SOLO, $15^{\circ}$, Campinas, Sociedade Brasileira de Ciência do Solo, Anais. 1976. p.359-362.

OLIVEIRA, J.B. \& PRADO, H. Carta pedológica Semi-detalhada do Estado de São Paulo. Folha de Piracicaba, Campinas Instituto Agronômico e Instituto Geográfico e Cartográfico. 1989 (escala 1:100.000). 
PEDRO, G.; CHAUVEL, A. \& MELFI, A. Recherces sur la constitution des Terra Roxa Estruturada du Brésil. Annalles Agronomie, 27(3):265-294. 1976.

PEDRO, G. Géochimie, mineralogie et organisation des sols. Aspects coordonnés des problèmes pédogénétiques. Cahiers Orstom, Série Pédologie, 23(3):169-186. 1987.

PENTEADO, M.M. Geomorfologia do Setor Centro Ocidental da Depressão Periférica Paulista. Tese de Doutoramento. FFCL de Rio Claro, 1968. Universidade de São Paulo, Instituto de Geografia. São Paulo. Série Teses e Monografias, N 22. 1976. $86 \mathrm{p}$.

PERECIN, D. \& CAMPOS, D.A.F. Evidências micromorfológicas de gênese de solos de Piracicaba. In: XV CONGRESSO BRASILEIRO DE CIÊNCIA SOLO, Campinas, 1975. Anais, p. 461-466. 1976.

PIERSON, F.B. \& MULLA, D.J. Aggregate stability in the Palouse region of Washington: Effect of landscape position. Soil Science Society America Journal 54:1407-1412. 1990.

QUEIROZ NETO, J.P.; CASTRO, S.S.; FERNANDES BARROS, O.N.; MANFREDINI, S.; RUELLAN, A. \& TOLEDO, G.S. Um estudo de dinâmica de solos: formação e transformação de perfís com horizonte B textural. In: CONGRESSO BRASILEIRO DE CIÊNCIA DO SOLO, Salvador, 1980. Campinas, Sociedade Brasileira de Ciência do Solo. Resumos. 1981. 
RABENHORST, M.C. \& WILDING, L.P. Pedogenesis on the Edwards Plateau, texas: I. Nature and continuity of parent material. Soil Science Society America Journal, 50:678-687. 1986.

RAIJ, B. Van; QUAGGIO, J.A.; CANTARELLA, H.; FERREIRA, M.E.;LOPES, A.S. \& BAtaglia, O.A. Análise de solos para fins de fertilidade. Campinas, Fundação Cargill, 1987. 165p.

RANZANI, G.; FREIRE, O. \& KINJO, T. Carta de solos do município de Piracicaba. Piracicaba, Centro de Estudos de Solos. ESALQ/USP, Brasil. 85p.. 1966.

RANZANI, G.; PENTEADO, M.M. \& SILVEIRA, J.D. Concreções ferruginosas, pelossolo $\mathrm{e}$ as superfícies de cimeira do Planalto Occidental Paulista: Geomorfologia, 31:1-28. 1972.

RUHE, R.V. Stone lines in soils. Soil Science. v. 87:223-231. 1959.

RUHE, R.V. Elements of soil landscapes. In: $7^{\mathrm{TH}}$ INTERNATIONAL CONGRESS OF SOIL SCIENCE, Madison, Wisc. USA. Proceedings, 1960. v.23, p. 165-171..

SANTOS, M.C.D.; MERMUT, A.R. \& RIBEIRO, M.R. Submicroscopy of clay microaggregates in an oxisol from Pernambuco, Brazil. Soil Science Society America Journal, 53:1895-1901. 1989.

SANTOS, M.C.D.; ST ARNAUD, R.J. \& ANDERSON, D.W. Quantitative evaluation of pedogenic changes in Boralfs (Gray Luvisols) of East Central Saskatchewan. Soil Science Society America Journal, 50:1014-1019. 1986. 
SIMONSON, R. Outline os a generalized theory of soil genesis. Soil Science Society Of America Proceedings 23: 152-156. 1959.

SOMBROEK, W.G. Soils with Nitic attributes.In: XIX CONGRÉS DE L'ASSOCIATION INTERNATIONALE DE LA SCIENCE DU SOL. Tokyo , Japon. 1990.

SOMBROEK, W.G. \& SIDERIUS, W. Nitosols and their genesis. In:Second meeting of the Eastern African sub-committee for soil correlationand land evaluation. Addis Adeba. FAO, World Soil Resources Reports, N0 47:84-86. 1976.

SOMBROEK, W.G. \& SIDERIUS, W. Nitosols, a quest for significant diagnostic criteria. Annual Report, International Soil Museum, Wageningen. p.11-31. 1981.

STOLT, M.H.; BAKER, J.C. \& SIMPSON, T.W. Soil-Landscape relationships in Virginia: I. Soil variability and parent material uniformity. Soil Science Society America Journal, 57:414-421. 1993.

STOOPS, G. Micromorphology of some characteristic soil of Lower Congo (Kinshasha). Pedologie, 18(1):110-149. 1968.

STOOPS, G. Micromorphology of the oxic horizon. Proceedings VIth International Workshop Meeting Soil Micromorphology, London. O. Bullock and C.P. Murphy ed., A.B. Academic Publishers, Rothamsted, 2:419-440. 1983.

STOOPS, G. \& BUOL, S.W. Micromorphology of oxisols. In: SOIL MICROMORPHOLOGY AND SOIL CLASSIFICATION. Proceedings of a symposium sponsored by Divisions S-5 and S-9 of the Soil Science Society of 
America, Anaheim. L.A. Douglas \& M.L. Thompson, ed. SSSA, Madison. 1985. 105-119p.

SUDOM, M.D. \& ST. ARNAUD, R.J. Use of quartz, zirconium and titanium as indices in pedological studies. Canadian Journal Soil Science, 51:385-396. 1971.

SUGUIO, K. Introdução à sedimentologia. Editora Edgard Blucher. 1973. p.317.

TERAMOTO, E.R. Relações solo, substrato geológico e superfícies geomórficas na microbacia do Ribeirão Marins (Piracicaba, SP). Piracicaba, Escola Superior de Agricultura "Luiz de Queiroz", USP, 1995. 120p. (Dissertação de Mestrado).

TRAPNELL, C.G. \& WEBSTER, R. Microaggregates in red earths and related soils in East and Central Africa, their classification and occurence. Journal of Soil Science, 37:109-123. 1986.

TRICART, J. Informações para a interpretação paleogeográfica dos cascalheiros. Noticia Geomorfológica, 4-11. 1959.

VAN LIER, Q de JONG \& VIDAL-TORRADO, P. PHI: programa de microcomputador para análise estatística da granulometria de sedimentos. Revista Brasileira de Ciência do Solo, 16:277-281, 1992.

VIDAL TORRADO, P. Relações solo $\mathrm{x}$ relevo em Mococa (SP); influência das carcterísticas topográficas e posição na vertente nos atributos do solo. Piracicaba, Escola Superior de Agricultura "Luiz de Queiroz", USP, 1989. 205p. (Dissertação de Mestrado) 
VIDAL TORRADO, P. Pedogênese e Morfogênese no Distrito de Tupi (Piracicaba-SP). Piracicaba, Escola Superior de Agricultura "Luiz de Queiroz", SP, 1994. 205p. (Tese de Doutoramento).

VIDAL TORRADO, P.; MAZZA, J.A.; CASTRO, S.S. \& DEMATTE, J.L.I. Micromorfologia e gênese de um Podzólico Vermelho Amarelo desenvolvido de sedimentos da formação Itararé no distrito de Tupi (Piracicaba-SP). In: $23^{\circ}$ CONGRESSO BRASILEIRO DE CIENCIA DO SOLO. Porto Alegre, julho de 1991. Resumos. Sociedade Brasileira de Ciência do Solo, Campinas, p.275. 1991.

VIDAL TORRADO, P. \& LEPSCH, I.F. Morfogênese de solos de uma topossequência com transição B latossólico x B textural sobre migmatitos em Mococa (SP). Revista Brasileira Ciência Solo. 17(1):109-119. 1993.

VIDAL TORRADO, P.; LEPSCH, I.F.; CASTRO, S.S.; COOPER, M. \& PESSOTTI, P.R.R. Pedogênese em uma catena com transição B latossólico - B textural sobre sedimentos pelíticos em Piracicaba, SP. In; XXV CONGRESSO BRASILEIRO DE CIÊNCIA DO SOLO. Viçosa, julho de 1995. Resumos expandidos, Sociedade Brasileira de Ciência do Solo, Campinas. p. 1503-1505. 1995. 
Apêndice 1

FOTOGRAFIAS AÉREAS DA ÁREA ESTUDADA 


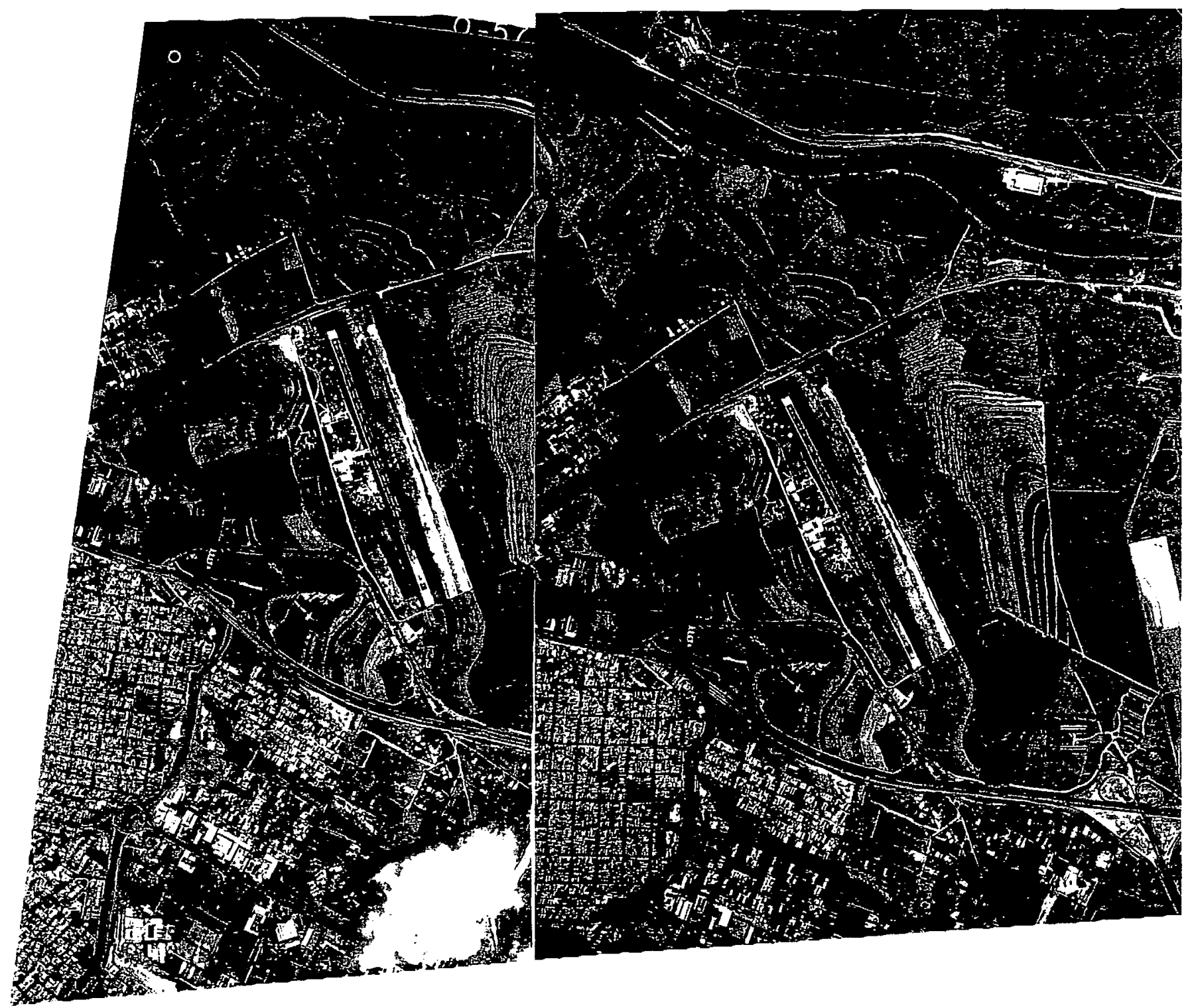




\section{Apêndice 2}

CÁLCULOS ESTATÍSTICOS DA DISTRIBUIÇÃO GRANULOMÊTRICA DA FRAÇÃO AREIA 
Miguel Cooper

Arquivo de entrada TP3B

Arquivo de saida TP3B.OUT

23-03-1996 $12: 18: 04$

TP3 $0-20$

intervalo phi

-1.00 a 0.00

0.00 a 1.00

1.00 a 2.00

2.00 a 3.00

3.00 a 4.30 valor abs

1.00

2.00

22.00

42.00

9.00 orel \%cum

$\begin{array}{ll}1 & 1 \\ 3 & 4\end{array}$

$29 \quad 33$

$55 \quad 88$

12100

Interpretacao do grafico (segundo Folk e Ward, 1957) : media grafica desvio padrao assimetria

2.246

0.699

$-0.017$

$+1.156$ moderadamente bem selecionado aproximadamente simetrica leptocurtico

$\begin{array}{rrr}\text { valor abs } & \% \text { rel } & \% \text { cum } \\ 0.00 & 0 & 0 \\ 2.00 & 3 & 3 \\ 28.00 & 39 & 42 \\ 35.00 & 49 & 90 \\ 7.00 & 10 & 100\end{array}$

do grafico (segundo Folk e Ward, 1957) : 2.157

0.670

$+0.093$

$+1.087$

moderadamente bem selecionado

aproximadamente simetrica

mesocurtico

TP3 $170-220$

$\begin{array}{rrrrr}\text { intervalo phi } & \text { valor abs } & \% \text { rel } & \% \text { cum } \\ -1.00 \text { a } & 0.00 & 0.00 & 0 & 0 \\ 0.00 \text { a } & 1.00 & 2.00 & 3 & 3 \\ 1.00 \text { a } & 2.00 & 38.00 & 50 & 53 \\ 2.00 \text { a } & 3.00 & 30.00 & 39 & 92 \\ 3.00 \text { a } & 4.30 & 6.00 & 8 & 100\end{array}$

Interpretacao do grafico (segundo Folk e Ward, 1957) : media grafica 2.035 desvio padrao 0.646 assimetria curtose $+0.210$ $+1.091$

moderadamente bem selecionado assimetria positiva (finos) mesocurtico 
TP3 $270-320$

\begin{tabular}{rrrrr}
\multicolumn{2}{l}{ intervalo phi } & valor abs & $\%$ rel & $\%$ cum \\
-1.00 a & 0.00 & 0.00 & 0 & 0 \\
0.00 a & 1.00 & 2.00 & 2 & 2 \\
1.00 a & 2.00 & 33.00 & 41 & 44 \\
2.00 a & 3.00 & 38.00 & 48 & 91 \\
3.00 a & 4.30 & 7.00 & 9 & 100
\end{tabular}

Interpretacao do grafico (segundo Folk e Ward, 1957) : media grafica 2.142 $\begin{array}{lrl}\text { desvio padrao } & 0.634 & \text { moderadamente bem selecionado } \\ \text { assimetria } & +0.145 & \text { assimetria positiva (finos) }\end{array}$ curtose +1.082 mesocurtico

\section{TP3 $370-420$}

intervalo phi -1.00 a 0.00 0.00 a 1.00 1.00 a 2.00 2.00 a 3.00 3.00 a 4.30

$\begin{array}{rrr}\text { valor abs } & \text { \%rel } & \% \text { cum } \\ 1.00 & 1 & 1 \\ 2.00 & 3 & 4 \\ 30.00 & 42 & 46 \\ 33.00 & 46 & 92 \\ 6.00 & 8 & 100\end{array}$

Interpretacao do grafico (segundo Folk e Ward, 1957) : media grafica 2.084 desvio padrao 0.662 assimetria $+0.079$ curtose $+1.081$

moderadamente bem selecionado aproximadamente simetrica mesocurtico

TP3 520-570

intervalo phi -1.00 a 0.00

0.00 a 1.00

1.00 a 2.00

2.00 a 3.00

3.00 a 4.30

valor abs \%rel \%cum

0.00

2.00

25.00

36.00

8.00

$\begin{array}{rr}0 & 0 \\ 3 & 3 \\ 35 & 38 \\ 51 & 89 \\ 11 & 100\end{array}$

Interpretacao do grafico (segundo Folk e Ward, 1957) : media grafica desvio padrao assimetria curtose 2.204

0.677 $+0.057$ $+1.100$ moderadamente bem selecionado aproximadamente simetrica mesocurtico 
TP3 $620-670$

$\begin{array}{rrrrr}\text { intervalo phi } & \text { valor abs } & \% \text { rel } & \% \text { cum } \\ -1.00 \mathrm{a} & 0.00 & 0.00 & 0 & 0 \\ 0.00 \mathrm{a} & 1.00 & 2.00 & 3 & 3 \\ 1.00 \mathrm{a} & 2.00 & 17.00 & 24 & 27 \\ 2.00 \mathrm{a} & 3.00 & 41.00 & 58 & 85 \\ 3.00 \mathrm{a} & 4.30 & 11.00 & 15 & 100\end{array}$

Interpretacao do grafico (segundo Folk e Ward, 1957) : media grafica 2.348 desvio padrao assimetria

0.687 moderadamente bem selecionado curtose -0.016 aproximadamente simetrica +1.201 leptocurtico 
Miguel Cooper

Arquivo de entrada TPC1

Arquivo de saida TPC1.OUT

$23-03-1996 \quad 12: 19: 25$

TPCI $70 \mathrm{~cm}$

$\begin{array}{rrrrr}\text { intervalo phi } & \text { valor abs } & \text { \%rel } & \text { \%cum } \\ -1.00 \text { a } & 0.00 & 1.43 & 3 & 3 \\ 0.00 \text { a } & 1.00 & 2.83 & 6 & 8 \\ 1.00 \text { a } & 2.00 & 8.33 & 16 & 24 \\ 2.00 \text { a } & 3.00 & 31.00 & 60 & 85 \\ 3.00 \text { a } & 4.30 & 7.84 & 15 & 100\end{array}$

Interpretacao do grafico (segundo Folk e Ward, 1957) :

media grafica 2.323

desvio padrao 0.820 moderadamente selecionado

assimetria $\quad-0.202$ assimetria negativa (grosseiros)

curtose +1.652

muito leptocurtico

TPC1 $116 \mathrm{~cm}$

intervalo phi

-1.00 a 0.00

0.00 a 1.00

valor abs \%rel \%cum

1.00 a 2.00

2.00 a 3.00

3.00 a 4.30

4.81

5.42

99

11.00

$28.60 \quad 51 \quad 89$

$6.20 \quad 11 \quad 100$

Interpretacao do grafico (segundo Folk e Ward, 1957) : media grafica desvio padrao assimetria 1.954

1.086 $-0.341$ pobremente selecionado curtose +1.253 leptocurtico

TPC1 $200 \mathrm{~cm}$

\begin{tabular}{rrrrr}
\multicolumn{1}{l}{ intervalo phi } & valor abs & $\%$ rel & $\%$ cum \\
-1.00 a & 0.00 & 2.95 & 8 & 8 \\
0.00 a & 1.00 & 2.76 & 7 & 15 \\
1.00 a & 2.00 & 4.50 & 12 & 27 \\
2.00 a & 3.00 & 19.15 & 51 & 78 \\
3.00 a & 4.30 & 8.20 & 22 & 100
\end{tabular}

Interpretacao do grafico (segundo Folk e Ward, 1957) : media grafica 2.243 desvio padrao 1.126 assimetria curtose

$-0.321$ $+1.524$ pobremente selecionado assimetria muito negativa (grosseiros) muito leptocurtico 
TPC1 $255 \mathrm{~cm}$

\begin{tabular}{rrrrr}
\multicolumn{2}{l}{ intervalo phi } & valor abs & \%rel & \%cum \\
$-1.00 \mathrm{a}$ & 0.00 & 3.79 & 11 & 11 \\
$0.00 \mathrm{a}$ & 1.00 & 3.73 & 11 & 21 \\
$1.00 \mathrm{a}$ & 2.00 & 4.77 & 13 & 35 \\
$2.00 \mathrm{a}$ & 3.00 & 15.14 & 43 & 77 \\
$3.00 \mathrm{a}$ & 4.30 & 8.00 & 23 & 100
\end{tabular}

Interpretacao do grafico (segundo Folk e Ward, 1957) : media grafica 2.034 desvio padrao 1.289 pobremente selecionado assimetria $\quad-0.334$ curtose +1.038 assimetria muito negativa (grosseiros) mesocurtico

TPC1 $340 \mathrm{~cm}$

intervalo phi

valor abs \%rel \%cum

-1.00 a 0.00

3.21

3.10

$11 \quad 11$

0.00 a 1.00

3.77

11

13

1.00 a 2.00

12.75

45

22

3.00 a 4.30

5.80

20

35

80

100

Interpretacao do grafico (segundo Folk e Ward, 1957) : media grafica 1.986 desvio padrao 1.275 assimetria $\quad-0.347$ curtose $\quad+1.039$

pobremente selecionado assimetria muito negativa (grosseiros) mesocurtico

TPC1 $360 \mathrm{~cm}$

intervalo phi

-1.00 a 0.00

0.00 a 1.00

1.00 a 2.00

2.00 a 3.00

3.00 a 4.30

valor abs

1.60

\%rel \%cum

2.71

$11 \quad 11$

2.37

$18 \quad 29$

5.15

3.13

$16 \quad 45$

$34 \quad 79$

$21 \quad 100$

Interpretacao do grafico (segundo Folk e Ward, 1957) : media grafica 1.880

desvio padrao 1.325

assimetria $\quad-0.250$

pobremente selecionado

curtose

$+0.824$

assimetria negativa (grosseiros)

platicurtico 
TPC1 $400 \mathrm{~cm}$

\begin{tabular}{rrrrr}
\multicolumn{2}{l}{ intervalo phi } & valor abs & $\%$ rel & $\%$ cum \\
-1.00 a & 0.00 & 1.75 & 15 & 15 \\
0.00 a & 1.00 & 1.79 & 15 & 30 \\
1.00 a & 2.00 & 1.68 & 14 & 44 \\
2.00 a & 3.00 & 3.94 & 33 & 76 \\
3.00 a & 4.30 & 2.82 & 24 & 100
\end{tabular}

Interpretacao do grafico (segundo Folk e Ward, 1957) : media grafica 1.830

desvio padrao 1.428 pobremente selecionado assimetria $\quad-0.292$

curtose +0.768 platicurtico assimetria negativa (grosseiros) 
Miguel Cooper

Arquivo de entrada TPC2

Arquivo de saida TPC2.OUT

23-03-1996 $12: 20: 28$

TPC2 $70 \mathrm{~cm}$

$\begin{array}{rrrrr}\text { intervalo phi } & \text { valor abs } & \% \text { rel } & \text { \%cum } \\ -1.00 \text { a } & 0.00 & 1.06 & 3 & 3 \\ 0.00 \text { a } & 1.00 & 2.13 & 6 & 8 \\ 1.00 \text { a } & 2.00 & 6.88 & 18 & 26 \\ 2.00 \text { a } & 3.00 & 21.80 & 57 & 83 \\ 3.00 \text { a } & 4.30 & 6.57 & 17 & 100\end{array}$

Interpretacao do grafico (segundo Folk e Ward, 1957) : media grafica 2.327

desvio padrao 0.854 moderadamente selecionado

assimetria -0.180 assimetria negativa (grosseiros)

curtose +1.496 leptocurtico

TPC2 $120 \mathrm{~cm}$

\begin{tabular}{rrrrr}
\multicolumn{2}{l}{ intervalo phi } & valor abs & $\%$ rel & $\%$ cum \\
-1.00 a & 0.00 & 1.33 & 4 & 4 \\
0.00 a & 1.00 & 1.48 & 4 & 8 \\
1.00 a & 2.00 & 5.04 & 15 & 23 \\
2.00 a & 3.00 & 19.70 & 58 & 81 \\
3.00 a & 4.30 & 6.61 & 19 & 100
\end{tabular}

Interpretacao do grafico (segundo Folk e Ward, 1957) : media grafica 2.393

desvio padrao 0.885 moderadamente selecionado assimetria -0.201 assimetria negativa (grosseiros)

curtose +1.663 muito leptocurtico

TPC2 $190 \mathrm{~cm}$

$\begin{array}{rrrrr}\text { intervalo phi } & \text { valor abs } & \% \text { rel } & \% \text { cum } \\ -1.00 \text { a } & 0.00 & 1.26 & 4 & 4 \\ 0.00 \text { a } & 1.00 & 1.57 & 5 & 9 \\ 1.00 \text { a } & 2.00 & 3.90 & 12 & 22 \\ 2.00 \text { a } & 3.00 & 16.00 & 51 & 73 \\ 3.00 \text { a } & 4.30 & 8.55 & 27 & 100\end{array}$

Interpretacao do grafico (segundo Folk e Ward, 1957) : media grafica 2.485 desvio padrao 0.955 moderadamente selecionado assimetria $\quad-0.217$ assimetria negativa (grosseiros) curtose +1.481 leptocurtico 
TPC2 $250 \mathrm{~cm}$

$\begin{array}{rrrrr}\text { intervalo phi } & \text { valor abs } & \% \text { rel } & \text { ocum } \\ -1.00 \text { a } & 0.00 & 0.90 & 3 & 3 \\ 0.00 \text { a } & 1.00 & 1.63 & 5 & 9 \\ 1.00 \text { a } & 2.00 & 4.24 & 14 & 23 \\ 2.00 \text { a } & 3.00 & 15.80 & 53 & 76 \\ 3.00 \text { a } & 4.30 & 7.17 & 24 & 100\end{array}$

Interpretacao do grafico (segundo Folk e Ward, 1957) : media grafica 2.439 $\begin{array}{lrl}\text { desvio padrao } & 0.917 & \text { moderadamente selecionado } \\ \text { assimetria } & -0.191 & \text { assimetria negativa (grosseiros) }\end{array}$ curtose +1.457 leptocurtico

TPC2 $370 \mathrm{~cm}$

$\begin{array}{rrrrr}\text { intervalo phi } & \text { valor abs } & \% \text { rel } & \text { \%cum } \\ -1.00 \text { a } & 0.00 & 3.57 & 18 & 18 \\ 0.00 \text { a } & 1.00 & 2.31 & 12 & 30 \\ 1.00 \text { a } & 2.00 & 3.00 & 15 & 46 \\ 2.00 \text { a } & 3.00 & 7.72 & 40 & 86 \\ 3.00 \text { a } & 4.30 & 2.77 & 14 & 100\end{array}$

Interpretacao do grafico (segundo Folk e Ward, 1957) : media grafica 1.652 desvio padrao 1.368 assimetria $-0.352$ curtose

pobremente selecionado assimetria muito negativa (grosseiros) platicurtico

TPC2 $400 \mathrm{~cm}$

$\begin{array}{rrrrr}\text { intervalo phi } & \text { valor abs } & \text { \%rel } & \% \text { cum } \\ -1.00 \text { a } & 0.00 & 2.00 & 22 & 22 \\ 0.00 \text { a } & 1.00 & 2.06 & 23 & 44 \\ 1.00 \text { a } & 2.00 & 1.46 & 16 & 60 \\ 2.00 \text { a } & 3.00 & 2.15 & 23 & 84 \\ 3.00 \text { a } & 4.30 & 1.48 & 16 & 100\end{array}$

Interpretacao do grafico (segundo Folk e Ward, 1957) : media grafica 1.410 desvio padrao 1.422 assimetria $\quad+0.056$ curtose $+0.714$

pobremente selecionado aproximadamente simetrica platicurtico 
TPC2 $440 \mathrm{~cm}$

$\begin{array}{rrrrr}\text { intervalo phi } & \text { valor abs } & \% \text { rel } & \text { \%cum } \\ -1.00 \text { a } & 0.00 & 3.66 & 21 & 21 \\ 0.00 \text { a } & 1.00 & 4.36 & 25 & 46 \\ 1.00 \text { a } & 2.00 & 3.12 & 18 & 63 \\ 2.00 \text { a } & 3.00 & 4.31 & 25 & 88 \\ 3.00 \text { a } & 4.30 & 2.10 & 12 & 100\end{array}$

Interpretacao do grafico (segundo Folk e Ward, 1957) : media grafica desvio padrao assimetria curtose

1.298

1.346 $+0.096$ $+0.754$ pobremente selecionado

aproximadamente simetrica platicurtico

TPC2 $460 \mathrm{~cm}$

intervalo phi valor abs \%rel \%cum

-1.00 a 0.00

4.66

3.70

25

0.00 a 1.00

2.64

1.00 a 2.00

4.77

25

20

45

3.00 a 4.30

3.00

59

$25 \quad 84$

16100

Interpretacao do grafico (segundo Folk e Ward, 1957) : media grafica 1.388 desvio padrao 1.438 assimetria $\quad+0.054$ curtose $+0.670$

pobremente selecionado aproximadamente simetrica platicurtico 
Miguel Cooper

Arquivo de entrada TP11B

Arquivo de saida TP11B. OUT

23-03-1996 $12: 21: 25$

TP11 $0-20$

intervalo phi

-1.00 a 0.00

0.00 a 1.00

valor abs

orel :cum

1.00 a 2.00

1.00

2.00

$\begin{array}{ll}1 & 1 \\ 3 & 4 \\ 2 & 33\end{array}$

2.00 a 3.00

20.00

$29 \quad 33$

3.00 a 4.30

37.00

$54 \quad 87$

$9.00 \quad 13 \quad 100$

Interpretacao do grafico (segundo Folk e Ward, 1957) : media grafica 2.258

desvio padrao 0.711 moderadamente selecionado

assimetria

$-0.009$

curtose

$+1.143$ aproximadamente simetrica leptocurtico

TP11 $70-120$

intervalo phi

-1.00 a 0.00

0.00 a 1.00

1.00 a 2.00

2.00 a 3.00

3.00 a 4.30

valor abs

rel ㄷm

1.00

2.00

33

$6 \quad 10$

$6.00 \quad 19 \quad 29$

$15.00 \quad 48 \quad 77$

$\begin{array}{lll}7.00 & 23 & 100\end{array}$

Interpretacao do grafico (segundo Folk e Ward, 1957) : media grafica 2.344

desvio padrao 0.961 moderadamente selecionado

$\begin{array}{lll}\text { assimetria } & -0.177 & \text { assimetria negativa } \\ \text { curtose } & +1.230 & \text { leptocurtico }\end{array}$

TP11 $170-220$

intervalo phi

-1.00 a 0.00

0.00 a 1.00

1.00 a 2.00

2.00 a 3.00

3.00 a 4.30

Interpretacao media grafica desvio padrao assimetria curtose

$\begin{array}{rrr}\text { valor abs } & \text { \%rel } & \text { \%cum } \\ 1.00 & 4 & 4 \\ 1.00 & 4 & 8 \\ 4.00 & 15 & 23 \\ 13.00 & 50 & 73 \\ 7.00 & 27 & 100\end{array}$

do grafico (segundo Folk e Ward, 1957) : 2.484

0.945

$-0.201$

$+1.427$

moderadamente selecionado

assimetria negativa (grosseiros)

leptocurtico 
TP11 220-270

$\begin{array}{rrrrr}\text { intervalo phi } & \text { valor abs } & \% \text { rel } & \% \text { cum } \\ -1.00 \text { a } & 0.00 & 1.00 & 4 & 4 \\ 0.00 \text { a } & 1.00 & 1.00 & 4 & 7 \\ 1.00 \text { a } & 2.00 & 4.00 & 15 & 22 \\ 2.00 \text { a } & 3.00 & 13.00 & 48 & 70 \\ 3.00 \text { a } & 4.30 & 8.00 & 30 & 100\end{array}$

Interpretacao do grafico (segundo Folk e Ward, 1957) : media grafica desvio padrao assimetria 2.540 0.933 $-0.197$ +1.359 leptocurtico

moderadamente selecionado curtose

TP11 $320-370$

intervalo phi -1.00 a 0.00

0.00 a 1.00

valor abs \%rel \%cum

1.00 a 2.00

2.00 a 3.00

3.00 a 4.30

$\begin{array}{rrr}3.00 & 12 & 12 \\ 2.00 & 8 & 19 \\ 4.00 & 15 & 35 \\ 10.00 & 38 & 73 \\ 7.00 & 27 & 100\end{array}$

Interpretacao do grafico (segundo Folk e Ward, 1957) : media grafica 2.094 desvio padrao 1.305 pobremente selecionado assimetria $\quad-0.330$ assimetria muito negativa (grosseiros) curtose $+1.052$ mesocurtico

TP11 $420-470$

intervalo phi -1.00 a 0.00 0.00 a 1.00 valor abs \%rel \%cum 1.00 a 2.00 2.00 a 3.00 3.00 a 4.30

$\begin{array}{rrr}2.00 & 8 & 8 \\ 3.00 & 12 & 20 \\ 4.00 & 16 & 36 \\ 10.00 & 40 & 76 \\ 6.00 & 24 & 100\end{array}$

Interpretacao do grafico (segundo Folk e Ward, 1957) : media grafica 2.098 desvio padrao 1.234 assimetria $\quad-0.290$ pobremente selecionado curtose $+1.013$ assimetria negativa (grosseiros) mesocurtico 


$\begin{array}{lrrrr}\text { TP11 } 520-570 & & & \\ \text { intervalo phi } & \text { valor abs } & \circ \text { rel } & \text { \%cum } \\ -1.00 \text { a } 0.00 & 3.00 & 17 & 17 \\ 0.00 \text { a } & 1.00 & 2.00 & 11 & 28 \\ 1.00 \text { a } & 2.00 & 3.00 & 17 & 44 \\ 2.00 \text { a } & 3.00 & 6.00 & 33 & 78 \\ 3.00 \text { a } & 4.30 & 4.00 & 22 & 100\end{array}$

Interpretacao do grafico (segundo Folk e Ward, 1957) : media grafica 1.773 desvio padrao 1.445 assimetria $\quad-0.312$ pobremente selecionado curtose $+0.811$ assimetria muito negativa (grosseiros) platicurtico

TP11 $620-670$

intervalo phi -1.00 a 0.00 0.00 a 1.00 1.00 a 2.00 2.00 a 3.00 3.00 a 4.30

$\begin{array}{rrr}\text { valor abs } & \text { \%rel } & \text { \%cum } \\ 2.00 & 9 & 9 \\ 2.00 & 9 & 18 \\ 3.00 & 14 & 32 \\ 8.00 & 36 & 68 \\ 7.00 & 32 & 100\end{array}$

Interpretacao do grafico (segundo Folk e Ward, 1957) : media grafica 2.227 desvio padrao 1.265 assimetria $-0.340$ curtose $+1.055$ pobremente selecionado assimetria muito negativa (grosseiros) mesocurtico 


\section{Apêndice 3}

DESCRIÇÃO MORFOLÓGICA DOS PERFIS 


\begin{tabular}{|c|c|c|c|c|c|c|c|c|c|c|}
\hline Pertiss & Teri & TROXY UatOSS & dica & & & & & & & \\
\hline HORZ & & STIUTUR & & TEXTURA & COR & & NSTSTEN & $\mathrm{TAP}$ & CRROSD: & TRANS \\
\hline PROS & FORMA & TAMANMO & GRAU & & & SEGA & $\mathrm{UMUA}$ & MOLTADA & & \\
\hline $\begin{array}{c}A \\
0-10 \mathrm{~cm}\end{array}$ & $\begin{array}{l}\text { blocos } \\
\text { subang. }\end{array}$ & pequenos & moderado & argilosa & 5YR 3/4 & dura & friavel & $\begin{array}{c}\text { năo } \\
\text { pegajoso } \\
\text { lig. } \\
\text { plástico }\end{array}$ & - & clara \\
\hline $\begin{array}{c}\text { BA } \\
10-40 \mathrm{~cm}\end{array}$ & $\begin{array}{l}\text { blocos } \\
\text { subang }\end{array}$ & pequenos & forte & argilosa &, $5 \mathrm{YR} 2.75$ & dura & friavel & $\begin{array}{c}\text { lig } \\
\text { pegajoso } \\
\text { plástico }\end{array}$ & - & gradual \\
\hline $\begin{array}{c}\text { Btl } \\
40-67 \mathrm{~cm}\end{array}$ & $\begin{array}{l}\text { blocos } \\
\text { subang. }\end{array}$ & medios & forte & argilosa & $2,5 \times \mathrm{YR} 3,5 / 4$ & dura & friavel & $\begin{array}{c}\text { pegajoso } \\
\text { plástico }\end{array}$ & $\begin{array}{l}\text { comum } \\
\text { fraca }\end{array}$ & gradual \\
\hline $\begin{array}{c}\mathrm{B} 2 \\
67-115 \mathrm{~cm}\end{array}$ & $\begin{array}{l}\text { blocos } \\
\text { subang. }\end{array}$ & medios & forte & argilosa & $2,5 \mathrm{YR} 3 / 5$ & dura & friavel & $\begin{array}{l}\text { pegajoso } \\
\text { plástica }\end{array}$ & $\begin{array}{c}\text { pouca } \\
\text { fraca }\end{array}$ & difusa \\
\hline $\begin{array}{c}\text { Bw1 } \\
115-235 c\end{array}$ & $\begin{array}{c}\text { blocos } \\
\text { subang. } \\
\text { que se } \\
\text { desfaz. } \\
\text { em } \\
\text { microag. }\end{array}$ & pequenos & fraca & argilosa & $2,5 \mathrm{YR} 4 / 6$ & dura & $\begin{array}{l}\text { muito } \\
\text { friavel }\end{array}$ & $\begin{array}{c}\text { lig } \\
\text { pegajosa } \\
\text { lig. } \\
\text { plástica }\end{array}$ & & gradual \\
\hline $\begin{array}{c}\text { Bt3 } \\
235- \\
285 \mathrm{~cm}\end{array}$ & $\begin{array}{l}\text { blocos } \\
\text { subang. }\end{array}$ & médio & forte & argilosa & $2,5 \mathrm{YR} 3 / 6$ & dura & $\begin{array}{c}\text { friável } \\
\text { a } \\
\text { firme }\end{array}$ & $\begin{array}{c}\text { lig. } \\
\text { plástica } \\
\text { lig } \\
\text { pegajosa }\end{array}$ & & gradual \\
\hline $\begin{array}{c}\text { Bw2 } \\
285- \\
465 \mathrm{~cm}\end{array}$ & $\begin{array}{l}\text { blocos } \\
\text { subang. } \\
\text { que se } \\
\text { desfaz. } \\
\text { em } \\
\text { microag. }\end{array}$ & $\begin{array}{c}\text { médio } \\
\text { pequenos }\end{array}$ & $\begin{array}{l}\text { fraco } \\
\text { forte }\end{array}$ & argilosa & 2,5YR 4/6 & dura & friável & $\begin{array}{c}\text { não } \\
\text { plástica } \\
\text { não } \\
\text { pegajosa }\end{array}$ & & abrupta \\
\hline $\begin{array}{c}\text { Linha de } \\
\text { pedras } \\
465- \\
480 \mathrm{~cm} .\end{array}$ & & & & & & & & & & \\
\hline $\begin{array}{c}\mathrm{C} \\
480- \\
580 \mathrm{~cm}\end{array}$ & & & & & & & & & & \\
\hline $\begin{array}{c}\text { Alt. de } \\
\text { diabásio } \\
580+\end{array}$ & & & & & & & & & & \\
\hline & Observaçõ̃ & & $\begin{array}{r}\text { Presen } \\
\text { Presença d }\end{array}$ & $\begin{array}{l}\text { de nódulos } \\
\text { Iguns seixos }\end{array}$ & $\begin{array}{l}\text { de argila nos } \\
\text { pequenos de }\end{array}$ & $\begin{array}{l}\text { rizontes } \\
\text { sartzo n }\end{array}$ & $\begin{array}{l}\text { 1 e Bw2 } \\
\text { rizonte } \mathrm{Bw}\end{array}$ & & & \\
\hline
\end{tabular}




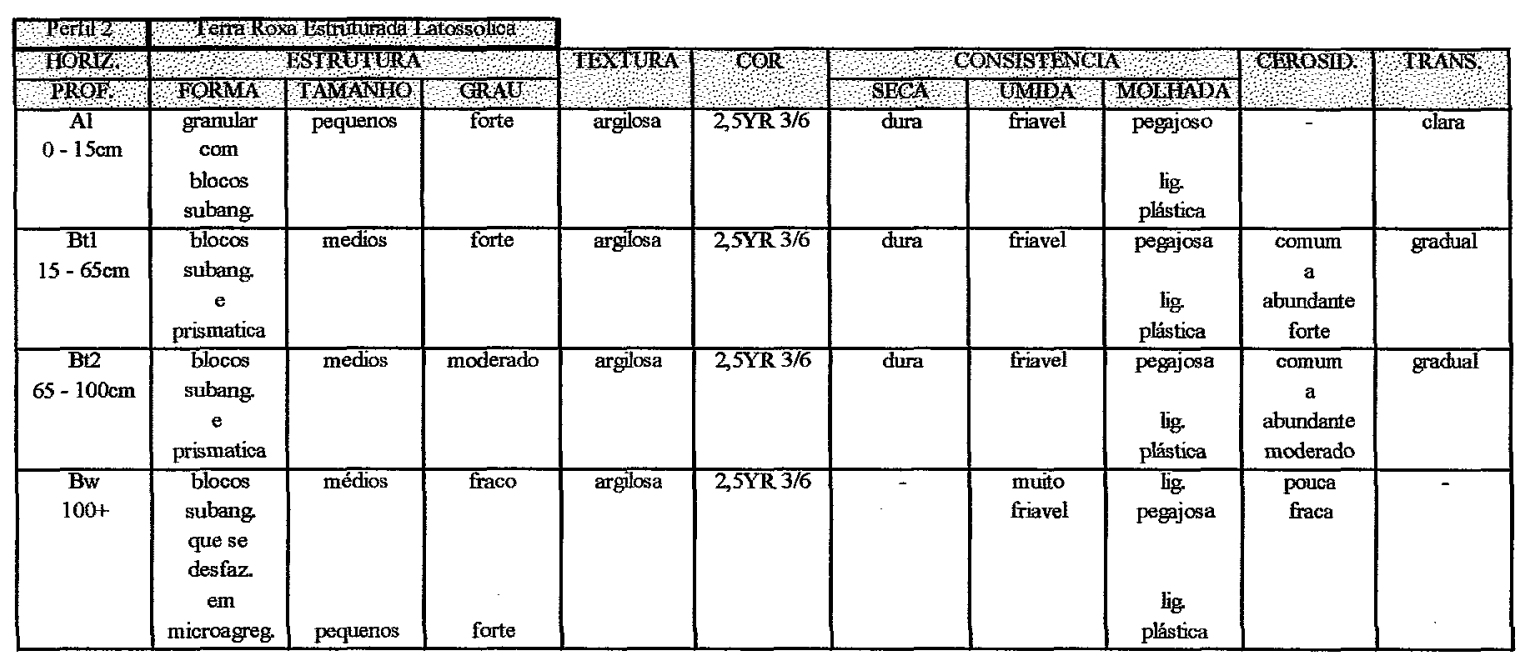

\begin{tabular}{|c|c|c|c|c|c|c|c|c|c|c|}
\hline Prentro & अ1\% & MKOXa HSTrU & da: & & & & & & & \\
\hline FORL & & STRUTURA & & TEXTURA & COR & & NSISTPN & & CKROSH & TRAMS: \\
\hline PROF & FORMA & TAMAN1KO & $\mathrm{GRAU}$ & ^ै। & & $\mathrm{SECA}$ & GMTDA & MOMIADA: & W & \\
\hline Al & gramular & pequenos & forte & argilosa & $2,5 \mathrm{YR} 2,75 / 4$ & - & friavel & pegajosa & - & clara \\
\hline $0-17 \mathrm{~cm}$ & $\begin{array}{c}\text { e } \\
\text { blocos } \\
\text { subang. }\end{array}$ & $\begin{array}{c}\text { e } \\
\text { medios }\end{array}$ & & & & & & & & \\
\hline $\begin{array}{c}\mathrm{AB} \\
17-60 \mathrm{~cm}\end{array}$ & $\begin{array}{l}\text { blocos } \\
\text { subang }\end{array}$ & medios & forte & argilosa & $2,5 \mathrm{YR} 3 / 4$ & - & friavel & pegajosa & $\begin{array}{l}\text { superficies } \\
\text { brithantes }\end{array}$ & gradual \\
\hline $\begin{array}{c}\text { Bt1 } \\
60-115 \mathrm{~cm}\end{array}$ & $\begin{array}{c}\text { blocos } \\
\text { subang } \\
e \\
\text { prisinatica }\end{array}$ & medios & forte & argilosa & 2,5YR 3/6 & - & friavel & pegajosa & $\begin{array}{c}\text { comum } \\
\text { a } \\
\text { abundante } \\
\text { moderado }\end{array}$ & gradual \\
\hline $\begin{array}{c}\mathrm{B} 2 \mathbf{2} \\
115-173 \mathrm{~cm}\end{array}$ & prismatica & medios & moderada & argilosa & $2,5 \mathrm{YR} 3 / 6$ & - & friavel & pegajosa & $\begin{array}{c}\text { comum } \\
\text { moderada }\end{array}$ & - \\
\hline $\begin{array}{c}\text { Linha } \\
\text { de pedras } \\
173+\end{array}$ & & & & & & & & & & \\
\hline
\end{tabular}

\begin{tabular}{|c|c|c|c|c|c|c|c|c|c|c|}
\hline Pertily & Tera & Roxp pouco p & rrabo & & & & & & & \\
\hline HORQ & & ESTRUTHAR & & TEXTURA & CoA & & MSISTEN & & GEROSD & TRANS \\
\hline PROF & FORAGA & TAKANAO & GAAE & & & SECA & UMINA & MOA APDA & ॥४ & \\
\hline $\begin{array}{c}\text { Ap } \\
0-5 \mathrm{~cm}\end{array}$ & $\begin{array}{l}\text { blacos } \\
\text { subang }\end{array}$ & $\begin{array}{c}\text { pequenos } \\
\mathbf{e} \\
\text { medios }\end{array}$ & forte & argilosa & $2,5 \mathrm{YR} 2,5 / 4$ & - & friavel & pegajosa & - & clara \\
\hline $\begin{array}{c}\overline{B A} \\
5-35 \mathrm{~cm}\end{array}$ & $\begin{array}{l}\text { blocos } \\
\text { subang. }\end{array}$ & $\begin{array}{c}\text { pequenos } \\
\text { e } \\
\text { medios }\end{array}$ & forte & argilosa & $2,5 \mathrm{YR} 2,75 / 4$ & - & friavel & pegajosa & $\begin{array}{c}\text { fraca } \\
\text { a } \\
\text { moderada } \\
\text { pouca }\end{array}$ & gradual \\
\hline $\begin{array}{c}\mathbf{B t} \\
35-70 \mathrm{~cm}\end{array}$ & $\begin{array}{c}\text { blocos } \\
\text { subang. } \\
\mathrm{e} \\
\text { prismaticos }\end{array}$ & medios & forte & argilosa & $2,5 \mathrm{YR} 3 / 4$ & - & friavel & pegajosa & $\begin{array}{l}\text { abundante } \\
\text { moderada }\end{array}$ & gradual \\
\hline $\begin{array}{c}\overline{B C} \\
70-135 \mathrm{~cm}\end{array}$ & $\begin{array}{c}\text { blocos } \\
\text { subang }\end{array}$ & $\begin{array}{c}\text { pequenos } \\
\text { e } \\
\text { medios }\end{array}$ & medrado & argilosa & $2,5 \mathrm{YR} 3 / 6$ & - & friavel & pegajosa & $\begin{array}{c}\text { comum } \\
\text { fraca } \\
\text { a } \\
\text { moderada }\end{array}$ & gradual \\
\hline $\begin{array}{c}\mathrm{C} \\
135+\end{array}$ & material & fiemperizado & diabasio & & 5YR 4/6 & & & & & \\
\hline
\end{tabular}


Latossolo Vermelho Amarelo

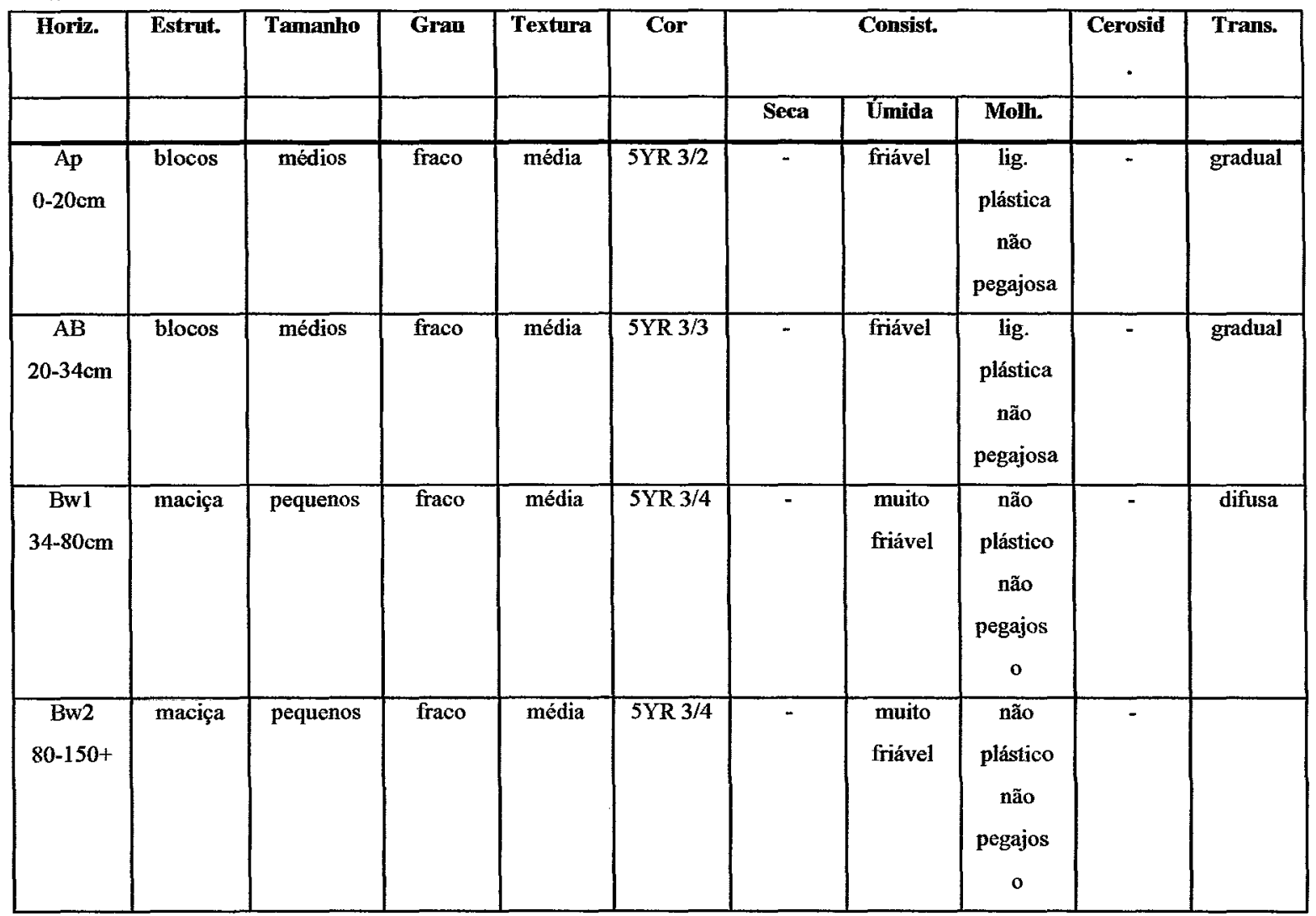




\section{Apêndice 4}

ANÁLISES DE GRANULOMETRIA dOS PONTOS ANALISADOS E DOS PERFIS DESCRITOS 
Tabela 1: Análises granulomêtricas das tradágens profundas.

\begin{tabular}{|c|c|c|c|c|c|c|c|c|c|c|c|c|}
\hline & \multicolumn{6}{|c|}{ AREIA (\%) } & \multirow{2}{*}{$\begin{array}{c}\text { SILTE } \\
\%\end{array}$} & \multicolumn{2}{|c|}{ ARGILA (\%) } & \multirow[t]{2}{*}{ DENST } & \multirow{2}{*}{$\frac{\mathrm{DS}}{\mathrm{g} / \mathrm{cm}}$} & \multirow[t]{2}{*}{ FLOCUL. } \\
\hline IDENTF & M.G. & G. & $\mathrm{M}$ & F. & M.F. & TOT. & & TOT. & AGUA & & & \\
\hline \multicolumn{13}{|l|}{ Tad Prof } \\
\hline 101020 & 0 & 2 & 18 & 48 & 14 & 82 & 2 & 16 & 26 & 0 & 0 & 0 \\
\hline $1 P 13050$ & 0 & 2 & 23 & 38 & 5 & 68 & 4 & 28 & 32 & 0 & 0 & 0 \\
\hline TP1 50100 & 0 & 2 & 32 & 36 & 5 & 75 & 4 & 21 & 19 & 0 & 0 & 0 \\
\hline $1 P 1100-150$ & 0 & 2 & 28 & 32 & 4 & 66 & 3 & 29 & 32 & 0 & 0 & 0 \\
\hline $\mathrm{TP} 150200$ & 0 & 2 & 23 & 45 & 10 & 80 & 2 & 18 & 2 & 0 & 0 & 0 \\
\hline $7 P 1200250$ & 0 & 1 & 34 & 37 & 4 & 76 & 4 & 20 & 8 & 0 & 0 & 0 \\
\hline 101250300 & 0 & 2 & 26 & 38 & 3 & 69 & 2 & 29 & 32 & 0 & 0 & 0 \\
\hline $\mathrm{T1300,350}$ & 0 & 2 & 30 & 31 & 4 & 67 & 4 & 29 & 29 & 0 & 0 & 0 \\
\hline 141350400 & 1 & 2 & 16 & 42 & 15 & 76 & 4 & 20 & 0 & 0 & 0 & 0 \\
\hline 111400450 & 0 & 1 & 16 & 38 & 9 & 64 & 6 & 30 & 32 & 0 & 0 & 0 \\
\hline $1 \mathrm{Pl} 450-500$ & 0 & 1 & 22 & 32 & 11 & 62 & 3 & 33 & 34 & 0 & 0 & 0 \\
\hline $1 \mathrm{P} 1500 \mathrm{s50}$ & $\theta$ & 1 & 15 & 39 & 9 & 64 & 4 & 32 & 32 & 0 & 0 & 0 \\
\hline $\mathrm{TP} 1550600$ & 0 & 1 & 17 & 42 & 13 & 73 & 4 & 23 & 13 & 0 & 0 & 0 \\
\hline \multicolumn{13}{|l|}{ Trad Hor 2} \\
\hline$T \mathrm{P} 2200-230$ & 0 & 3 & 40 & 31 & 2 & 75 & 4 & 21 & 18 & 0 & 0 & 0 \\
\hline $\mathrm{TP} 230=280$ & 0 & 2 & 34 & 26 & 4 & 66 & 4 & 30 & 32 & 0 & 0 & 0 \\
\hline $\mathrm{TP} 2280-320$ & 0 & 2 & 21 & 35 & 8 & 66 & 4 & 30 & 31 & 0 & 0 & 0 \\
\hline $1+2320370$ & 1 & 2 & 23 & 43 & 1 & 86 & 3 & 21 & 16 & 0. & 0 & 0 \\
\hline $\mathrm{TP} 270420$ & 0 & 2 & 29 & 37 & 6 & 74 & 6 & 20 & 1 & 0 & 0 & 0 \\
\hline $\mathrm{TP} 2420170$ & 1 & 2 & 30 & 38 & 3 & 74 & 4 & 22 & 4 & 0 & 0 & 0 \\
\hline $1 \mathrm{P2} 470520$ & 0 & 2 & 46 & 20 & 4 & 12 & 5 & 23 & 4 & 0 & 0 & 1 \\
\hline $\mathrm{TP} 2520-570$ & 0 & 2 & 26 & 38 & 3 & 69 & 5 & 26 & 2 & 0 & 0 & 0 \\
\hline \multicolumn{13}{|l|}{ Trad 1 rof } \\
\hline $\mathrm{TH} O 020$ & 1 & 2 & 22 & 42 & 9 & 76 & 8 & 16 & 13 & 0 & 0 & 0 \\
\hline $\mathrm{TP} 32070$ & 0 & 1 & 22 & 40 & 7 & 70 & 1 & 23 & 15 & 0 & 0 & 0 \\
\hline $1 P 370120$ & 0 & 2 & 28 & 35 & 7 & 72 & 4 & 24 & 31 & 0 & 01 & 0 \\
\hline $101120-170$ & 0 & 1 & 20 & 48 & 11 & 80 & 6 & 14 & 11 & 0 & 0 & 0 \\
\hline $103170-220$ & 0 & 2 & 38 & 30 & 6 & 76 & 2 & 22 & 31 & 0 & 0 & 0 \\
\hline $103220<20$ & 0 & 2 & 35 & 33 & 1 & 74 & 1 & 21 & 2 & 0 & 0 & 0 \\
\hline $1 \mathrm{P} 3270320$ & 0 & 2 & 33 & 38 & 1 & 80 & 3 & 17 & 0 & 0 & 0 & 0 \\
\hline 103320370 & 0 & 2 & 29 & 37 & 6 & 14 & 3 & 21 & 2 & 0 & 0 & 0 \\
\hline $\mathrm{TP} 3370 \% 420$ & 1 & 2 & 30 & 33 & 6 & 72 & 4 & 24 & 32 & 0 & 0 & 0 \\
\hline $\mathrm{TP} 320470$ & 0 & 2 & 30 & 32 & 6 & 70 & 4 & 26 & 34 & 0 & 0 & 0 \\
\hline $\mathrm{TSS} 520-570$ & 0 & 2 & 26 & 38 & 3 & 69 & 5 & 26 & 2 & 0 & 0 & 0 \\
\hline 17570620 & 0 & 2 & 18 & 41 & 10 & 11 & 3 & 24 & 0 & 0 & 0 & 0 \\
\hline $1 \mathrm{TP} 3620670$ & 0 & 2 & 17 & 41 & 11 & 1 & 5 & 24 & 1 & 6 & 0 & 0 \\
\hline
\end{tabular}

(cont.) 


\begin{tabular}{|c|c|c|c|c|c|c|c|c|c|c|c|c|}
\hline \multirow[b]{2}{*}{ IDENTIF } & \multicolumn{6}{|c|}{ AREIA (\%) } & \multirow{2}{*}{$\begin{array}{c}\text { SILTE } \\
\%\end{array}$} & \multicolumn{2}{|c|}{ ARGILA (\%) } & \multirow{2}{*}{ DENSD } & \multirow{2}{*}{$\frac{\mathrm{DS}}{\mathrm{g} / \mathrm{cm}}$} & \multirow[t]{2}{*}{ FLOCUI } \\
\hline & MG. & G. & M. & F. & M.F. & TOT. & & TOT. & AGUA & & & \\
\hline \multicolumn{13}{|l|}{$\mathrm{Trad}$ roo } \\
\hline $1 \mathrm{P40} 00$ & 1 & 2 & 16 & 44 & 14 & 7 & 1 & 16 & 60 & 0 & 0 & 0 \\
\hline TP4 2070 & 0 & 2 & 18 & 40 & 13 & 13 & 8 & 19 & 4 & 0 & 0 & 0 \\
\hline $\mathrm{TP} 470120$ & 1 & 2 & 20 & 39 & 10 & 12 & 5 & 23 & 3 & 0 & 0 & 0 \\
\hline $1 \mathrm{P} 4120-170$ & 1 & 2 & 16 & 42 & 13 & 14 & 4 & 22 & 3 & 0 & 0 & 0 \\
\hline $1 T 4170220$ & 0 & 2 & 28 & 31 & 6 & 67 & 4 & 29 & 1 & 0 & 0 & 0 \\
\hline 194220270 & 0 & 2 & 23 & 34 & 7 & 66. & 4 & 30 & 1 & 0 & 0 & 0 \\
\hline $7 \mathrm{P} 4270-320$ & 0 & 2 & 25 & 33 & 8 & 68 & 4 & 28 & 1 & 0 & 0 & 0 \\
\hline $714320-370$ & 0 & 2 & 18 & 43 & 12 & 15 & 4 & 21 & 2 & 0 & 0 & 0 \\
\hline $74370+420$ & 0 & 2 & 35 & 29 & 6 & 12 & 2 & 26 & 1 & 0 & 0 & 0 \\
\hline 194420,470 & 0 & 2 & 28 & 34 & 1 & 7 & 2 & 27 & 2 & 0 & 0 & 0 \\
\hline $\mathrm{TP4} 70 \mathrm{s20}$ & 0 & 2 & 16 & 40 & 12 & 10 & 3 & 25 & 3 & 0 & 0 & 0 \\
\hline $7{ }^{4} 520-70$ & 0 & 2 & 23 & 36 & 1 & 68 & 2 & 30 & 0 & 0 & 0 & 0 \\
\hline $1 P 4570020$ & 0 & 2 & 35 & 28 & 4 & 69 & 4 & 27 & 1 & 0 & 0 & 0 \\
\hline $1 \mathrm{P} 4620,670$ & 0 & 2 & 28 & 34 & 7 & 71 & 2 & 27 & 1 & 0 & 0 & 0 \\
\hline \multicolumn{13}{|l|}{ Trd, Prols } \\
\hline $\mathrm{TP} 50 \mathrm{20}$ & 1 & 2 & 20 & 37 & 12 & 12 & 6 & 22 & 12 & 0 & 0 & 0 \\
\hline $1 P 52070$ & 1 & 2 & 23 & 36 & 9 & 11 & 5 & 24 & 1 & 0 & 0 & 0 \\
\hline $10 s, 0120$ & 1 & 2 & 19 & 38 & 12 & 72 & 4 & 24 & 1 & 0 & 0 & 0 \\
\hline $105120-170$ & 0 & 2 & 21 & 41 & 1 & 75 & 4 & 21 & 1 & 0 & 0 & 0 \\
\hline $195170-220$ & 1 & 2 & 28 & 35 & 8 & 74 & 4 & 22 & 2 & 0 & 0 & 0 \\
\hline 1052202270 & 0 & 2 & 21 & 37 & 12 & 12 & 4 & 24 & 0 & 0 & 0 & 0 \\
\hline 105270320 & 0 & 2 & 18 & 38 & 12 & 10 & 5 & 25 & 0 & 0 & 0 & 0 \\
\hline $1 \mathrm{PS} 320=370$ & 1 & 2 & 22 & 38 & 9 & 72 & 3 & 25 & 0 & 0 & 0 & 0 \\
\hline 105370420 & 0 & 2 & 32 & 32 & 8 & 74 & 4 & 22 & 2 & 0 & 0 & 0 \\
\hline $\mathrm{TPS}_{20} 470$ & 1 & 2 & 21 & 39 & 11 & 74 & 4 & 22 & 0 & 0 & 0 & 0 \\
\hline $105470-520$ & 1 & 2 & 26 & 35 & 9 & 73 & 3 & 24 & 0 & 0 & 0 & 0 \\
\hline $10520<70$ & 1 & 2 & 21 & 39 & 8 & 7 & 2 & 26 & 1 & 0 & 0 & 0 \\
\hline TPS 70620 & 0 & 2 & 31 & 36 & 7 & 76 & 3 & 21 & 1 & 0 & 0 & 0 \\
\hline $\mathrm{TPS} 620-670$ & 11 & 3 & 30 & 36 & 8 & 78 & 2 & 20 & 0 & 0 & 0 & 0 \\
\hline 10670720 & 1 & 3 & 38 & 28 & 1 & 7 & 4 & 19 & 2 & 0 & 0 & 0 \\
\hline \multicolumn{13}{|l|}{ Trad prof 6} \\
\hline $1+6020$ & 1 & 2 & 19 & 34 & 11 & 67 & 9 & 24 & 15 & 0 & 0 & 0 \\
\hline 1062070 & 1 & 2 & 18 & 36 & 11 & 68 & 8 & 24 & 2 & 0 & 0 & 0 \\
\hline $1 \mathrm{Pr} 70120$ & 1 & 2 & 16 & 38 & 14 & 71 & 5 & 24 & 0 & 0 & 0 & 0 \\
\hline 106120170 & 2 & 2 & 16 & 39 & 14 & 13 & 3 & 22 & 0 & 0 & 0 & 0 \\
\hline 106170220 & 1 & 2 & 22 & 38 & 10 & 13 & 8 & 22 & 1 & 0 & 0 & 0 \\
\hline $106220-270$ & 1 & 2 & $1 s$ & 36 & 12 & 66 & 1 & 27 & 2 & 0 & 0 & 0 \\
\hline 176270320 & 1 & 2 & 16 & 37 & 12 & 68 & 5 & 27 & 2 & 0 & 0 & 0 \\
\hline 106320370 & 1 & 2 & 16 & 41 & 13 & 73 & 4 & 23 & 2 & 0 & 0 & 0 \\
\hline $196 \times 70420$ & 1 & 2 & 15 & 37 & 13 & 68 & 5 & 27 & 0 & 0 & 0 & 8 \\
\hline $\mathrm{TP6} 420470$ & 9 & 8 & 11 & 25 & 11 & 64 & 8 & 28 & 13 & 0 & 0 & 10 \\
\hline
\end{tabular}

(cont.) 


\begin{tabular}{|c|c|c|c|c|c|c|c|c|c|c|c|c|}
\hline & \multicolumn{6}{|c|}{ AREIA (\%) } & \multirow{2}{*}{$\begin{array}{c}\text { SILTE } \\
\%\end{array}$} & \multicolumn{2}{|c|}{ ARGILA (\%) } & \multirow{2}{*}{\begin{tabular}{|l|} 
DENSID \\
\end{tabular}} & \multirow{2}{*}{$\frac{\mathrm{DS}}{\mathrm{g} / \mathrm{cm}}$} & \multirow[t]{2}{*}{ FLOCUL } \\
\hline IDENTIF & M.G. & G. & M. & F. & M.F. & TOT. & & TOT. & AGUA & & & \\
\hline \multicolumn{13}{|l|}{ Trad Proft } \\
\hline TP 10 & 1 & 3 & 8 & 31 & 8 & 5144 & 10 & 37 & औ & 0 & 0 & 0 \\
\hline $1 P 770116$ & 5 & 5 & 11 & 29 & 6 & 86,81 & 14 & 27 & $\$$ & 0 & 0 & 0 \\
\hline $\mathrm{TP} 716,200$ & 3 & 3 & 5 & 19 & 8 & 375 & 19 & 40 & \% & 0 & 0 & 0 \\
\hline $1 \mathrm{PT} 201025 \mathrm{~s}$ & 4 & 4 & 3 & 15 & 8 & 3,43 & 19 & 44 & 3 & 0 & 0 & 0 \\
\hline$T P 7250200$ & 4 & 3 & 4 & 12 & 3 & 2728 & 10 & 49 & 8 & 0 & 0 & 0 \\
\hline $\mathrm{TP}>290340$ & 3 & 3 & 4 & 13 & 6 & 28,62 & 24 & 51 & 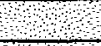 & 0 & 0 & 0 \\
\hline $1 P 7340360$ & 1 & 3 & 2 & 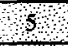 & 3. & 1452 & 34 & 11 & & 0 & 0 & 0 \\
\hline $\mathrm{TP} 7360400$ & 2 & 2 & 2 & 4 & 3 & 12 & 26 & 66 & & 0 & 0 & 0 \\
\hline \multicolumn{13}{|l|}{ Trad Pof 8} \\
\hline 198020 & 0 & 2 & 26 & 34 & 10 & 22 & 1 & 21 & 8 & 0 & 0 & 0 \\
\hline $1 P 820-70$ & 2 & 3 & 14 & 26 & 9 & 54 & 11 & 35 & 0 & 0 & 0 & 0 \\
\hline $1 P 870120$ & 2 & 3 & 16. & 88 & 7 & 56 & 10 & 34 & 0 & 0 & 0 & 0 \\
\hline $128120-170$ & 5 & 5 & 12 & 26 & 10 & 58 & 14 & 28 & 0 & 0 & 0 & 0 \\
\hline 108170220 & 17 & 11 & 11 & 20 & 11 & 70 & 1 & 23 & 1 & 0 & 0 & 0 \\
\hline 178220270 & 11 & 11 & 9 & 13 & 6 & 56 & 9 & 35 & 10 & 0 & 0 & 0 \\
\hline $\mathrm{TP} 8270320$ & 2 & 3 & 3 & 11 & 6 & 27 & 14 & 59 & 8 & 0 & 0 & 0 \\
\hline $\mathrm{TP8} 320370$ & 5 & 4 & 3 & 10 & 1 & 31 & 18 & 51 & 13 & 0 & 0 & 0 \\
\hline $\mathrm{TPS} 370,420$ & 3 & 2 & 4 & 10 & 5 & 24 & 14 & 62 & 4 & 0 & 0 & 0 \\
\hline $\mathrm{TPB} 420470$ & 3 & 2 & 3 & 5 & 4 & 17 & 26 & 87 & 3 & 0 & 0 & 0 \\
\hline \multicolumn{13}{|l|}{ Tha pol 2} \\
\hline 11970 & 106 & 213 & 688 & 218 & 657 & 384 & 17 & 48 & & 0 & 0 & 0 \\
\hline $\mathrm{TP} 910120$ & 133 & 148 & 5,04 & 197 & 6,61 & 3416 & 13 & 46 & भ & 0 & 0 & 0 \\
\hline$P P Q 120-190$ & 1,6 & 1,5 & 39 & 16 & 855 & 3128 & 16 & 49 & 8 & 0 & 0 & 0 \\
\hline TP 190250 & 09 & 163 & 424 & 15,8 & 117 & 297 & 16 & 51 & & 0 & 0 & 0 \\
\hline 109250370 & 3,57 & 231 & 3 & 7,72 & 277 & 1937 & 19 & 64 & & 0 & 0 & 0 \\
\hline 109370400 & 2 & 206 & 146 & 2,15 & 148 & 915 & 26 & 62 & ? & 0 & 0 & 0 \\
\hline $\mathrm{PPO} 400440$ & 366 & 436 & 312 & 31 & 21 & 175 & 13 & 62 & & 0 & 0 & 0 \\
\hline $\mathrm{TP} 940460$ & 4,66 & 3,1 & 2,64 & 477 & 3 & 187 & 27 & 53 & भे & 0 & 0 & 0 \\
\hline \multicolumn{13}{|l|}{ Trad pros 10} \\
\hline $\mathrm{TP} 00020$ & 3 & 3 & 9 & 16 & 8 & 39 & 8 & 53 & 34 & 0 & 1 & 0 \\
\hline $1 P 102070$ & 0 & 2 & 20 & 36 & 10 & 68 & 6 & 26 & 20 & 0 & 0 & 0 \\
\hline TP10 70120 & 1 & 1 & 6 & 13 & 6 & 27 & 13 & 60 & 8 & 0 & 0 & 0 \\
\hline 191012017 & 1 & 1. & 6 & 14 & 6 & 28 & 14 & 58 & 0 & 0 & 0 & 0 \\
\hline 181017022 & 2 & 2 & 3 & 14 & 1 & 30 & 14 & 36 & 0 & 0 & 0 & 0 \\
\hline $1 \mathrm{P10} 22027$ & 1 & 1 & 6 & 18 & 9 & 35 & 14 & 51 & 1 & 0 & 0 & 0 \\
\hline
\end{tabular}

(cont.) 


\begin{tabular}{|c|c|c|c|c|c|c|c|c|c|c|c|c|}
\hline & \multicolumn{6}{|c|}{ AREIA (\%) } & \multirow{2}{*}{$\begin{array}{c}\text { SILTE } \\
\%\end{array}$} & \multicolumn{2}{|c|}{ ARGILA (\%) } & \multirow{2}{*}{ DENSD } & \multirow{2}{*}{$\frac{\mathrm{DS}}{\mathrm{g} / \mathrm{cm}}$} & \multirow[t]{2}{*}{ FLOCUL } \\
\hline IDENTIF & MG. & G. & M. & F. & M.F. & TOT. & & Tor. & AGUA & & & \\
\hline \multicolumn{13}{|l|}{ Trod Brof 1} \\
\hline TP110 020 & 1 & 2 & 20 & 37 & 9 & 69 & 7 & 24 & 16 & 0. & 0 & 0 \\
\hline $1 P 12070$ & 2 & 2 & 8 & 18 & 1 & 37 & 12 & 51 & 4 & 0 & 0 & 0 \\
\hline 101170120 & 1 & 2 & 6 & 15 & 7 & 31 & 12 & 57 & 20 & 0 & 0 & 0 \\
\hline $1 P 1112017$ & 1 & 1 & 5 & 13 & 8 & 28 & 11 & 61 & 12 & 0 & 0 & 0 \\
\hline $1 P 1117022$ & 1 & 1 & 4 & 13 & 7 & 26 & 13 & 61 & 3 & 0 & 0 & 0 \\
\hline $1 P 11 / 2027$ & 1 & 1 & 4 & 13 & 8 & 27 & 15 & 38 & 3 & 0 & 0 & 0 \\
\hline 191127032 & 1 & 1 & 3 & 14 & 7 & 38 & 14 & 58 & 2 & 0 & 0 & 0 \\
\hline $\mathrm{LP1132037}$ & 3 & 2 & 4 & 10 & 3 & 26 & 18 & 5 & 3 & 0 & 0 & 0 \\
\hline $1 P 11370,42$ & 2 & 2 & 5 & 10 & 1 & 26 & 21 & 53 & 2 & 0 & 0 & 0 \\
\hline T11 42047 & 2 & 3 & 4 & 10 & 6 & 25 & 25 & 50 & 2 & 0 & 0 & 0 \\
\hline 111147032 & 2 & 2 & 4 & 9 & 4 & 21 & 26 & 53 & 2 & 0 & 0 & 0 \\
\hline $\mathrm{rP} 1 \mathrm{~s} 2 \mathrm{O}=5$ & 3 & 2 & 3 & 6 & 4 & 18 & 29 & 53 & 2 & 0 & 0 & 0 \\
\hline $1 P 11506$ & 1 & 2 & 4 & 8 & 6 & 21 & 32 & 47 & 0 & 0 & 0 & 0 \\
\hline $1 \mathrm{P} 102067$ & 1 & 2 & 3 & 8 & 7 & 21 & 32 & 47 & 1 & 0 & 0 & 0 \\
\hline 181167072 & 1 & 1 & 3 & 9 & 5 & 19 & 36 & 45 & 2 & 0 & 0 & 0 \\
\hline \multicolumn{13}{|l|}{ Trad prof 12} \\
\hline $1 \mathrm{P1} 2020$ & 1 & 1 & 1 & 16 & 8 & 33 & 18 & 49 & 42 & 0 & 0 & 0 \\
\hline $1+122070$ & 0 & 1 & 4 & 11 & 6 & 22 & 9 & 69 & 24 & 0 & 0 & 0 \\
\hline TP12 70120 & 0 & 1 & 4 & 10 & 6 & 21 & 14 & 65 & 28 & 0 & 0 & 0 \\
\hline 112120170 & 0 & 1 & 3 & 13 & 9 & 30 & 10 & 60 & 1 & 0 & 0 & 0 \\
\hline 101217022 & 1 & 1 & 5 & 14 & 7 & 38 & 11 & 6 & 3 & 0 & 0 & 0 \\
\hline 11122027 & 0 & 1 & 4 & 13 & 8 & 26 & 12 & 62 & 1 & 0 & 0 & 0 \\
\hline 191207032 & 1 & 1 & 4 & 11 & 6 & 23 & 15 & 62 & 9 & 0 & 0 & 0 \\
\hline 101232037 & 0 & 1 & 4 & 13 & 8 & 26 & 15 & 39 & 3 & 0 & 0 & 0 \\
\hline 101237042 & 1 & 1 & 4 & 13 & 9 & 28 & 15 & 57 & 2 & 0 & 0 & 0 \\
\hline $1 P 12420,47$ & 1 & 1 & 4 & 12 & 6 & 24 & 18 & 58 & 2 & 0 & 0 & 0 \\
\hline $\mathrm{SP} 12,70 \mathrm{s2}$ & 0 & 1 & 3 & 9 & 1 & 20 & 25 & 55 & 2 & 0 & 0 & 0 \\
\hline 101202057 & 0 & 0 & 4 & 10 & 6 & 20 & 32 & 48 & 2 & 0 & 0 & 0 \\
\hline 181257062 & 0 & 1 & 3 & 10 & 6 & 20 & 32 & 48 & 2 & 0 & 0 & 0 \\
\hline 81262067 & 0 & 0 & 3. & 10 & 8 & 21 & 38 & 41 & 2 & 0 & 0 & 0 \\
\hline $\mathrm{TP1} 67072$ & 0 & 1 & 3 & 12 & 1 & 25 & 37 & 38 & 2 & 0 & 0 & 0 \\
\hline
\end{tabular}




\begin{tabular}{|c|c|c|c|c|c|c|c|c|c|c|c|c|c|}
\hline IDENTTF & PROF. & \multicolumn{6}{|c|}{ AREIA (\%) } & SILTE & \multicolumn{2}{|c|}{ ARGILA (\%) } & D.P. & D.S. & FLOCUL. \\
\hline & & M.G. & G. & $\mathbf{M}$ & F & M.F. & TOT. & $\%$ & TOT. & $\overline{\text { AGUA }}$ & \multicolumn{2}{|c|}{ g/cm3 } & $\%$ \\
\hline Pefil 2 & & & & & & & & & & & & & \\
\hline $\mathrm{AD}$ & $\mathrm{g}-16 \mathrm{~cm}$ & मा & 2 & 9 & 21 & 6 & 39 & 14 & 47 & 8 & 0 & 0 & 83 \\
\hline $\mathrm{BHO}$ & $44+1 \mathrm{ho}$ & 0 & 3 & 4 & 12 & 5 & 2 & 3 & 65 & 2 & 0 & 0 & 82 \\
\hline BHAC & $6371 \mathrm{~cm}$ & 0 & 1 & 5 & 12 & 4 & 27 & 15 & 64 & 11 & 0 & 0 & 83 \\
\hline$B 2$ & $80 \circ 88 \mathrm{O}$ & 0 & 1 & 7 & 18 & 9 & 35 & 12 & 53 & 1 & 0 & 0 & 87 \\
\hline $\mathrm{BD} / \mathrm{B}$ W & $9 \mathrm{~s}-10 \mathrm{sm}$ & 0 & 11 & 3 & 10 & 4 & 18 & 12 & 65 & 8 & $\theta$ & 0 & 88 \\
\hline $\mathrm{BH}$ & $145-155 \mathrm{G}$ & 8 & 1 & 4 & 15 & 8 & 27 & 1 & 61 & 8 & 0 & 0 & 87 \\
\hline
\end{tabular}

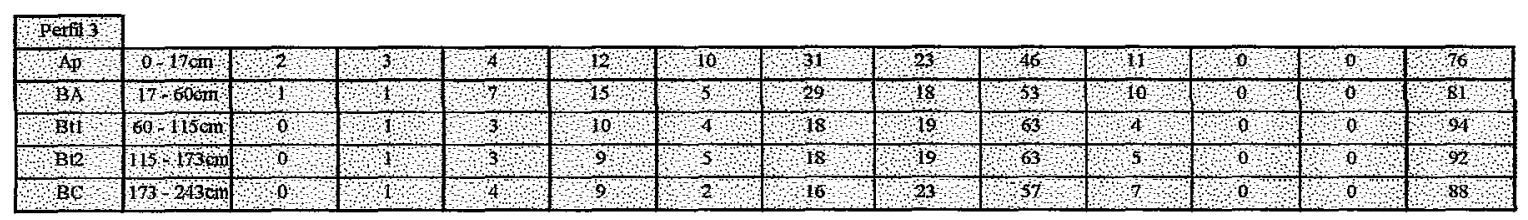

\begin{tabular}{|c|c|c|c|c|c|c|c|c|c|c|c|c|c|}
\hline $\mathrm{A}$ & $0 \mathrm{sch}$ & 2 & 2 & $\mathrm{I}$ & 13 & $\mathrm{~s}$ & 40 & 25 & 35 & 30 & 0 & 0 & 14 \\
\hline $\mathrm{Bt1}$ & $5-35 \mathrm{~cm}$ & 3 & 1 & 12 & 13 & 3 & 40 & 20 & 80 & 35 & 0 & 0 & 13 \\
\hline $\mathrm{BD}$ & 35 tocit & 4 & 8 & 111 & $\mathrm{mit}$ & 3 & 31 & 19 & 44 & 40 & 0 & 0 & 8 \\
\hline $\mathrm{BC}$ & $70-135 \mathrm{gin}$ & 1 & 10 & 11 & 112 & 5 & 41 & 20 & 39 & 13 & 0 & 0 & 6 \\
\hline 0 & 135 & 13 & 14 & 34 & 12 & 5 & 58 & 21 & 21 & 1 & 0 & 0 & 25 \\
\hline
\end{tabular}

Análises granulométricas dos perfis estudados. 


\section{Apêndice 5}

MICROMORFOLOGIA DOS PERFIS DA TOPOSSEQUÊNCIA ESTUDADA. 


\begin{tabular}{|c|c|c|c|c|c|}
\hline \multirow[b]{2}{*}{ Atributo } & \multicolumn{5}{|c|}{ Horizonte } \\
\hline & Bt1 $(49-61 \mathrm{~cm})$ & $\begin{array}{c}\text { Transição Bt1/Bt2 } \\
(65-82 \mathrm{~cm})\end{array}$ & $\begin{array}{c}\text { Transição Bt2/Bw1 } \\
(100-115 \mathrm{~cm})\end{array}$ & $\begin{array}{c}\text { Bwl } \\
(160-175 \mathrm{~cm})\end{array}$ & $\begin{array}{c}\text { Transição Bw1/Bt3 } \\
(218 \mathrm{~cm})\end{array}$ \\
\hline Plasma & $\begin{array}{l}60 \%, \text { vermelho } \\
\text { escuro, argila } \\
\text { mineralógica, e } \\
\text { óxidos de ferro, } \\
\text { isótico }\end{array}$ & $\begin{array}{l}65 \% \text {, vermelho } \\
\text { escuro, argila } \\
\text { mineralógica e } \\
\text { óxidos de ferro, } \\
\text { isótico com } \\
\text { tendência a } \\
\text { vossépico }\end{array}$ & $\begin{array}{l}\text { Duas zonas: A) } \\
55 \% \text {, vermelho } \\
\text { escuro, isótico. } \\
\text { B) } 55 \% \text {, vermelho } \\
\text { escuro, isótico }\end{array}$ & $\begin{array}{l}\text { Duas zonas: A) } \\
60 \% \text {, vermelho } \\
\text { escuro, isótica com } \\
\text { tendência local a } \\
\text { esquelvossépica. } \\
\text { B) } 45 \% \text {, vermelho } \\
\text { escuro, isótica. }\end{array}$ & $\begin{array}{l}\text { Duas zonas: } \mathbf{A} \text { ) } \\
40 \% \text {, vermelho } \\
\text { escuro, isótico. } \\
\text { B) } 40 \% \text {, vermelho } \\
\text { escuro, isótico. }\end{array}$ \\
\hline Esqueleto & $\begin{array}{l}20 \%, \text { Quartzo } \\
\text { subarredondado e } \\
\text { mal selecionado, } \\
\text { presença de alguns } \\
\text { minerais opacos }\end{array}$ & $\begin{array}{l}20 \% \text {, Quartzo } \\
\text { subarredondado e } \\
\text { mal selecionado, } \\
\text { alguns opacos }\end{array}$ & $\begin{array}{l}\text { A) } 30 \%, \text { Quartzo } \\
\text { subarredondado e } \\
\text { moderadamente } \\
\text { selecionado. } \\
\text { B) } 20 \% \text {, quartzo } \\
\text { subarredondado e } \\
\text { moderadamente } \\
\text { selecionado }\end{array}$ & $\begin{array}{l}\text { A) } 30 \% \text {, quartzo } \\
\text { subarredondado. } \\
\text { B) } 20 \% \text {, quartzo } \\
\text { subarredondado e } \\
\text { mal selecionado, } \\
\text { presença de } \\
\text { esqueleto triado do } \\
\text { tamanho do silte } \\
\text { dentro de alguns } \\
\text { microagregados. }\end{array}$ & $\begin{array}{l}\text { A) } 35 \% \text {, quartzo } \\
\text { subarredondado. } \\
\text { B) } 20 \% \text {, quartzo } \\
\text { subarredondados } \\
\text { apresentando alguns } \\
\text { subangulares. }\end{array}$ \\
\hline Poros & $\begin{array}{l}20 \%, \text { Predominio de } \\
\text { ortocavidades } \\
\text { mamelonadas e } \\
\text { fissurais, alguns } \\
\text { canais e câmaras }\end{array}$ & $\begin{array}{l}15 \%, \text { Predominio de } \\
\text { ortocavidades } \\
\text { mamelonares e } \\
\text { irregulares e } \\
\text { fissurais. }\end{array}$ & $\begin{array}{l}\text { A) } 15 \% \text {, } \\
\text { Predominio de } \\
\text { ortocavidades } \\
\text { mamelonados e } \\
\text { fissurais. } \\
\text { B) } 25 \% \text {, } \\
\text { Predominio de } \\
\text { intergranulares com } \\
\text { algumas } \\
\text { ortocavidades e } \\
\text { fissuras. }\end{array}$ & $\begin{array}{l}\text { A) } 10 \% \text {, } \\
\text { predominio de } \\
\text { ortocavidades e } \\
\text { presença de } \\
\text { algumas fissuras. } \\
\text { B) } 35 \% \text {, de } \\
\text { empilhamento } \\
\text { complexo com } \\
\text { porosidade tubular } \\
\text { causado por } \\
\text { organismos. }\end{array}$ & $\begin{array}{l}\text { A) } 25 \% \text {, } \\
\text { predominio de } \\
\text { fissurais algunmas } \\
\text { ortocavidades } \\
\text { mamelonadas. } \\
\text { B) } 40 \% \text {, predominio } \\
\text { de intergranulares } \\
\text { complexos e alguns } \\
\text { fissurais }\end{array}$ \\
\hline Trama & Porfürica fechada & $\begin{array}{l}\text { Porfírica fechada } \\
\text { com tendência local } \\
\text { a enáulica fechada. }\end{array}$ & $\begin{array}{l}\text { A) Porfírica } \\
\text { B) Enáulica }\end{array}$ & $\begin{array}{l}\text { A) Porfírica fechada } \\
\text { B) Enáulica }\end{array}$ & $\begin{array}{l}\text { A) Porfírica fechada } \\
\text { B) Enáulica }\end{array}$ \\
\hline Feições & $\begin{array}{l}\text { Cutãs de difusão e } \\
\text { ferriargilãs de } \\
\text { iluviação ( } 2,5 \%) \text {. } \\
\text { No interior dos } \\
\text { agregados } \\
\text { poliédricos há uma } \\
\text { tendência } \\
\text { micronodular, } \\
\text { dando lugar a uma } \\
\text { pedalidade } \\
\text { moderada. } \\
\text { Agrotúbulos } \\
\text { elipticos e tubulares }\end{array}$ & $\begin{array}{l}\text { Cutãs de difusão e } \\
\text { ferriargilãs de } \\
\text { iluviação (5\%). } \\
\text { Agregados } \\
\text { poliédricos com } \\
\text { tendência a } \\
\text { micronodular, } \\
\text { dando lugar auma } \\
\text { pedalidade } \\
\text { moderada. } \\
\text { Agrotúbulos } \\
\text { elipticos e tubulares }\end{array}$ & $\begin{array}{l}\text { A) Presença de } \\
\text { agrotúbulos } \\
\text { elipticos e } \\
\text { tubulares. } \\
\text { B) Presença de } \\
\text { agrotúbulos } \\
\text { elípticos e } \\
\text { tubulares. }\end{array}$ & $\begin{array}{l}\text { A) Presença de } \\
\text { agrotúbulos } \\
\text { circulares e } \\
\text { elípticos. Agregados } \\
\text { subangulares, } \\
\text { pedalidade fraca. } \\
\text { B) Presença de } \\
\text { agrotúbulos } \\
\text { circulares. Presença } \\
\text { de microagregados } \\
\text { ovais, poliêdricos e } \\
\text { irregulares. } \\
\text { Pedalidade forte. }\end{array}$ & $\begin{array}{l}\text { A) Agrotúbulos } \\
\text { abobadados e } \\
\text { elípticos formados } \\
\text { por organismos. } \\
\text { Pedalidade forte, } \\
\text { agregados } \\
\text { subangulares } \\
\text { B) Idem à zona A. } \\
\text { Pedalidade forte, } \\
\text { microagregados, } \\
\text { poliêdricos e ovais } \\
\text { (alguns com } \\
\text { esqueleto triado) }\end{array}$ \\
\hline
\end{tabular}

Micromorfologia do Perfil 1. Classificação do solo: Terra Roxa Estruturada Latossólica, eutrófico, A moderado, textura muito argilosa. 


\begin{tabular}{|c|c|c|c|c|c|}
\hline \multirow[b]{2}{*}{ Atributo } & \multicolumn{5}{|c|}{ Horizonte } \\
\hline & Bt3 (240-255cm) & $\begin{array}{c}\text { Transição Bt3/Bw2 } \\
(280-300 \mathrm{~cm})\end{array}$ & $\begin{array}{c}\text { Bw2 } \\
(340-357 \mathrm{~cm})\end{array}$ & $\begin{array}{c}C \mathbf{C} \\
(500-513 \mathrm{~cm})\end{array}$ & $\begin{array}{c}\text { Alterita } \\
(645-660 \mathrm{~cm})\end{array}$ \\
\hline Plasma & $\begin{array}{l}50 \% \text {, vermelho } \\
\text { escuro, argila } \\
\text { mineralógica, e } \\
\text { óxidos de ferro, } \\
\text { isótico }\end{array}$ & $\begin{array}{l}50 \% \text {, vermelho } \\
\text { escuro, argila } \\
\text { mineralógica e } \\
\text { oxidos de ferro, } \\
\text { isótico } \\
\end{array}$ & $\begin{array}{l}45 \% \text {, vermelho } \\
\text { escuro, isótico, } \\
\text { argila mineralógica } \\
\text { e óxidos de ferro. }\end{array}$ & $\begin{array}{l}70 \% \text {, vermelho, } \\
\text { isótica com } \\
\text { tendência } \\
\text { bimassepica. }\end{array}$ & $\begin{array}{l}65 \% \text {, vermelho } \\
\text { amarelo, isótico. }\end{array}$ \\
\hline Esqueleto & $\begin{array}{l}35 \%, \text { Quartzo } \\
\text { subarredondado, } \\
\text { presença de alguns } \\
\text { minerais opacos }\end{array}$ & $\begin{array}{l}20 \%, \text { Quartzo } \\
\text { subarredondado, } \\
\text { cariados e } \\
\text { ferruginizados. } \\
\text { Apresenta alguns } \\
\text { campos com } \\
\text { orientação } \\
\text { indicando atividade } \\
\text { biológica. }\end{array}$ & $\begin{array}{l}20 \%, \text { Quartzo } \\
\text { subarredondado, } \\
\text { subangular e mal } \\
\text { selecionado. }\end{array}$ & $\begin{array}{l}10 \%, \text { quartzo } \\
\text { subarredondado e } \\
\text { subangular, } \\
\text { presença de alguns } \\
\text { seixos de } 1 \text { a } 2 \mathrm{~mm} \\
\text { de quartzito. }\end{array}$ & $\begin{array}{l}25 \% \text {, predominio de } \\
\text { material de } \\
\text { diabásio,e } 5 \% \text { de } \\
\text { quartzo } \\
\text { subangulaRevista }\end{array}$ \\
\hline Poros & $\begin{array}{l}15 \% \text {, Predominio de } \\
\text { fissurais e presença } \\
\text { de canais }\end{array}$ & $\begin{array}{l}30 \%, \text { Predominio de } \\
\text { porosidade de } \\
\text { empilhamento } \\
\text { alguns fissurais. }\end{array}$ & $\begin{array}{l}35 \%, \text { Predominio de } \\
\text { porosidade de } \\
\text { empilhamento } \\
\text { complexo, algumas } \\
\text { ortocavidades } \\
\text { mamelonadas. }\end{array}$ & $\begin{array}{l}20 \%, \text { predominio de } \\
\text { porosidade de } \\
\text { empilhamento,ortoc } \\
\text { avidades e fissuras. }\end{array}$ & $\begin{array}{l}10 \% \text {, predominio de } \\
\text { ortocavidades, } \\
\text { fissuras e } \\
\text { porosidade de } \\
\text { empilhamento. }\end{array}$ \\
\hline Trama & Porfírica fechada & Enáulica & Enáulica & Porfiro-enáulica & Porfírica \\
\hline Feições & $\begin{array}{l}\text { Presença de } \\
\text { agrotúbulos } \\
\text { circulares formados } \\
\text { por organismos }\end{array}$ & $\begin{array}{l}\text { Presença de } \\
\text { agrotúbulos } \\
\text { elípticos e } \\
\text { alveolares de } \\
\text { dimensões entre } 1,5 \\
\text { a } 2 \mathrm{~mm} \text {. Pedalidade } \\
\text { forte, } \\
\text { microagregados } \\
\text { subangulares e } \\
\text { subarredondados }\end{array}$ & $\begin{array}{l}\text { Presença de } \\
\text { agrotubulos } \\
\text { elipticos e } \\
\text { circulares. } \\
\text { Pedalidade forte, } \\
\text { microagragados } \\
\text { esféricos e ovais } \\
\text { alguns destes } \\
\text { apresentam quartzo } \\
\text { triado. }\end{array}$ & $\begin{array}{l}\text { Presença de } \\
\text { agrotúbulos } \\
\text { tubulares circulares } \\
\text { e elípticos. } \\
\text { Agregados } \\
\text { subarredondados, } \\
\text { pedalidade } \\
\text { moderada a forte. }\end{array}$ & $\begin{array}{l}\text { Agrotúbulos } \\
\text { elipticos formados } \\
\text { por organismos. } \\
\text { Pedalidade } \\
\text { moderada, } \\
\text { agregados } \\
\text { subarredondados }\end{array}$ \\
\hline
\end{tabular}

\section{Micromorfologia do Perfil 1 (cont.). Classificação do solo: Terra Roxa Estruturada Latossólica, eutrófico, A moderado, textura muito argilosa.}




\begin{tabular}{|c|c|c|c|c|c|}
\hline \multirow[b]{2}{*}{ Atributo } & \multicolumn{5}{|c|}{ Horizonte } \\
\hline & Bt1 $(44-51 \mathrm{~cm})$ & $\begin{array}{c}\text { Transição Bt1/Bt2 } \\
(63-71 \mathrm{~cm})\end{array}$ & $\begin{array}{c}\mathrm{Bt2} \\
(80-88 \mathrm{~cm}) \\
\end{array}$ & $\begin{array}{c}\text { Transição Bt2/Bw } \\
(95-105 \mathrm{~cm})\end{array}$ & $\begin{array}{c}\mathrm{Bw} \\
(145-155 \mathrm{~cm}) \\
\end{array}$ \\
\hline Plasma & $\begin{array}{l}60 \% \text {, vermelho escuro, } \\
\text { argila mineralógica, e } \\
\text { oxidos de ferro, isótico } \\
\text { com tendência a } \\
\text { esquelmossepica }\end{array}$ & $\begin{array}{l}60 \% \text {, vermelho escuro, } \\
\text { argila mineralógica e } \\
\text { oxidos de ferro, isótico } \\
\text { e com tendência } \\
\text { esquelvomassépica }\end{array}$ & $\begin{array}{l}50 \% \text {, vermelho } \\
\text { escuro, isótico com } \\
\text { tendência } \\
\text { esquelvomassépica, } \\
\text { argila mineralógica } \\
\text { e óxidos de ferro. }\end{array}$ & $\begin{array}{l}\text { A) } 40 \% \text {, vermelho } \\
\text { escuro,argila } \\
\text { mineralógica e oxidos de } \\
\text { ferro, isótico com } \\
\text { tendência argilassépica. } \\
\text { B) } 60 \% \text {, vermelho } \\
\text { escuro, composição } \\
\text { idem a A, isótico. }\end{array}$ & $\begin{array}{l}40 \% \text {, vermelho escuro, } \\
\text { isótico. }\end{array}$ \\
\hline Esqueleto & $\begin{array}{l}20 \%, \text { Quartzo } \\
\text { subarredondado e } \\
\text { moderadamente } \\
\text { selcionado, presença } \\
\text { de alguns minerais } \\
\text { opacos }\end{array}$ & $\begin{array}{l}25 \%, \text { Quartzo } \\
\text { subarredondado, } \\
\text { cariados e } \\
\text { ferruginizados. } \\
\text { Apresenta alguns } \\
\text { campos com } \\
\text { orientação indicando } \\
\text { atividade biológica. } \\
\end{array}$ & $\begin{array}{l}20 \%, \text { Quartzo } \\
\text { subarredondado. } \\
\text { Apresenta alguns } \\
\text { campos orientados } \\
\text { indicando atividade } \\
\text { biológica. }\end{array}$ & $\begin{array}{l}\text { A) } 20 \% \text {, quartzo } \\
\text { subarredondado liso. } \\
\text { B) } 15 \% \text {, quartzo } \\
\text { subarredondado liso }\end{array}$ & $\begin{array}{l}20 \%, \text { predominio de } \\
\text { quartzo subarredondado } \\
\text { e cariado }\end{array}$ \\
\hline Poros & $\begin{array}{l}20 \% \text {, Predominio de } \\
\text { ortocavidades fissurais } \\
\text { e presença de canais }\end{array}$ & $\begin{array}{l}15 \% \text {, Predominio de } \\
\text { ortocavidades } \\
\text { epresença de câmaras e } \\
\text { fissuras. }\end{array}$ & $\begin{array}{l}30 \% \text {, Predominiode } \\
\text { canais e } \\
\text { ortocavidades. } \\
\text { Presnça de fissuras. }\end{array}$ & $\begin{array}{l}\text { A) } 40 \% \text {, predominio de } \\
\text { porosidade de } \\
\text { empilhamento e fissuras. } \\
\text { B) } 25 \% \text {, predominio de } \\
\text { ortocavidades e fissuras, } \\
\text { alguns canais }\end{array}$ & $\begin{array}{l}40 \% \text {, predominio de } \\
\text { porosidade de } \\
\text { empilhamento e algumas } \\
\text { fissuras. }\end{array}$ \\
\hline Trama & Porfírica aberta & Porfirica aberta & $\begin{array}{l}\text { Porfirica com } \\
\text { alguns dominios } \\
\text { enaulicos }\end{array}$ & $\begin{array}{l}\text { A) Enáulica } \\
\text { B) Porfírica }\end{array}$ & Enáulica \\
\hline Feições & $\begin{array}{l}\text { Presença de } \\
\text { ferroargilãs (5\%) e } \\
\text { cutãs de difusão. } \\
\text { Formação de neo-cutãs } \\
\text { por movimentação de } \\
\text { ferro. Presença de } \\
\text { pápulas. }\end{array}$ & $\begin{array}{l}\text { Presença de } \\
\text { ferroargilãs de } \\
\text { iluviação e cutans de } \\
\text { difusão (5\%). } \\
\text { Pedalidade moderada, } \\
\text { agregados } \\
\text { subangulares }\end{array}$ & $\begin{array}{l}\text { Presença de } \\
\text { ferriargilãs de } \\
\text { iluviação (1\%). } \\
\text { Presença de } \\
\text { agrotúbulos } \\
\text { elipticos. } \\
\text { Pedalidade } \\
\text { moderada, } \\
\text { agregados } \\
\text { subangulares. }\end{array}$ & $\begin{array}{l}\text { A) Pedalidade forte, } \\
\text { microagregados } \\
\text { subangulares e ovais. } \\
\text { B)Presença de } \\
\text { agrotúbulo tubulares } \\
\text { Agregados } \\
\text { subarredondados, } \\
\text { pedalidade moderada a } \\
\text { forte. Pedalidade } \\
\text { moderada, agregados } \\
\text { subangulares com alguns } \\
\text { microagregados ovais e } \\
\text { poliêdricos. }\end{array}$ & $\begin{array}{l}\text { Agrotúbulos elípticos, } \\
\text { tubulares e abobadados. } \\
\text { Pedalidade forte, } \\
\text { predominam } \\
\text { microagregados ovais e } \\
\text { poliédricos }\end{array}$ \\
\hline
\end{tabular}

\section{Micromorfologia do Perfil 2. Classificação do solo: Terra Roxa Estruturada Latossólica, eutrófico, A moderado, textura muito argilosa.}




\begin{tabular}{|c|c|c|c|c|}
\hline \multirow[b]{2}{*}{ Atributo } & \multicolumn{4}{|c|}{ Horizonte } \\
\hline & BA (17-60cm) & Bt1 $(60-115 \mathrm{~cm})$ & $\mathrm{BL} 2(115-173 \mathrm{~cm})$ & $\mathrm{BC}(173-243 \mathrm{~cm})$ \\
\hline Plasma & $\begin{array}{l}70 \% \text {, vermelho escuro, } \\
\text { argila mineralógica, e } \\
\text { óxidos de ferro, isótico }\end{array}$ & $\begin{array}{l}60 \% \text {, vermelho escuro, } \\
\text { argila mineralógica e } \\
\text { oxidos de ferro, isótico } \\
\text { com tendência a } \\
\text { esquelvossépico }\end{array}$ & $\begin{array}{l}60 \% \text {, vermelho escuro } \\
\text { com zonas mais } \\
\text { amareladas de } \\
\text { segregação de ferro, } \\
\text { tendência isótico com } \\
\text { dominios massepicos, } \\
\text { argila mineralógica e } \\
\text { óxidos de ferro. }\end{array}$ & $\begin{array}{l}\text { A) } 70 \% \text {, vermelho } \\
\text { escuro, isótica com } \\
\text { tendência argilassépica, } \\
\text { e vossépica. Argila } \\
\text { mineralógica e óxidos } \\
\text { de ferro. } \\
\text { B) } 50 \% \text {, vermelho } \\
\text { escuro, isótica com } \\
\text { tendência silassépica. } \\
\text { Composição idem a A. }\end{array}$ \\
\hline Esqueleto & $\begin{array}{l}10 \%, \text { Quartzo } \\
\text { predomina } \\
\text { subarredondado e } \\
\text { subangular associada, } \\
\text { mal selecionado }\end{array}$ & $\begin{array}{l}15 \% \text {, Quartzo } \\
\text { predominam os } \\
\text { subarredondado e } \\
\text { alguns subangulares, } \\
\text { mal selecionado. }\end{array}$ & $\begin{array}{l}15 \% \text {, Quartzo } \\
\text { subarredondado, } \\
\text { subangular e mal } \\
\text { selecionado. Presença } \\
\text { de alguns nódulos } \\
\text { ferruginosos. }\end{array}$ & $\begin{array}{l}\text { A) } 10 \% \text {, quartzo } \\
\text { subarredondado não } \\
\text { orientado e minerais } \\
\text { opacos. } \\
\text { B) } 20 \% \text {, quartzo } \\
\text { subarredondado (pred.) } \\
\text { e subangular } \\
\text { (associado) e minerais } \\
\text { opacos. }\end{array}$ \\
\hline Poros & $\begin{array}{l}20 \% \text {, Predominio de } \\
\text { fissurais, ortocavidades } \\
\text { e canais }\end{array}$ & $\begin{array}{l}25 \% \text {, Predominio de } \\
\text { fissuras e porosidade de } \\
\text { empilhamento algumas } \\
\text { ortocavidades e canais. }\end{array}$ & $\begin{array}{l}25 \% \text {, Predominio de } \\
\text { fissuras e ortocavidades } \\
\text { (mamelonadas), alguns } \\
\text { canais e câmaras. }\end{array}$ & $\begin{array}{l}\text { A) } 20 \% \text {, predominio de } \\
\text { ortocavidades e } \\
\text { fissuras, algumas } \\
\text { câmaras. } \\
\text { B) } 30 \% \text {, predominio de } \\
\text { porosidade de } \\
\text { empilhamento e } \\
\text { ortocavidades e fissuras } \\
\text { associadas. }\end{array}$ \\
\hline Trama & Porfírica fechada & Porfírica fechada & Porfírica fissurada & $\begin{array}{l}\text { A) Porfírica } \\
\text { B)Enáulica }\end{array}$ \\
\hline Feiçōes & $\begin{array}{l}\text { Presença de agrotúbulos } \\
\text { circulares formados por } \\
\text { raizes. }\end{array}$ & $\begin{array}{l}\text { Presença de ferriargilãs } \\
\text { de iluviação }(5 \%) \text {.. } \\
\text { Pedalidade forte, } \\
\text { agregados subangulares } \\
\text { e poliêdricos alguns } \\
\text { microagregados ovais. }\end{array}$ & $\begin{array}{l}\text { Presença de ferriargilãs } \\
(<1 \%) \text { e cutans de } \\
\text { stress. Presença de } \\
\text { pápulas de argiluviação } \\
\text { e quasi-cutans de } \\
\text { difusão de ferro. } \\
\text { Pedalidade moderada a } \\
\text { forte, agregados }\end{array}$ & $\begin{array}{l}\text { A) Presença de poucos } \\
\text { ferriargilãs (<1\%). } \\
\text { Pedalidade moderada, } \\
\text { agregados subangulares } \\
\text { (2-3mm). } \\
\text { B) Presença de nódulos. } \\
\text { Pedalidade forte, } \\
\text { microagregados ovais e } \\
\text { poliêdricos (100um). }\end{array}$ \\
\hline
\end{tabular}

Micromorfologia do Perfil 3. Classificação do solo: Terra Roxa Estruturada, eutrófico, A moderado, textura muito argilosa. 


\begin{tabular}{|c|c|c|c|c|}
\hline \multirow[b]{2}{*}{ Atributo } & \multirow[b]{2}{*}{ Bt1 (8-18cm) } & \multicolumn{3}{|c|}{ Horizonte } \\
\hline & & $\mathrm{Bt} 2(48-58 \mathrm{~cm})$ & $\mathrm{BC}(83-130 \mathrm{~cm})$ & $\mathrm{CB}(135150))$ \\
\hline Plasma & $\begin{array}{l}50 \% \text {, vermelho escuro, } \\
\text { argila mineralógica, e } \\
\text { óxidos de ferro, } \\
\text { tendência isótica com } \\
\text { domínios massépicos }\end{array}$ & $\begin{array}{l}60 \% \text {, vermelho escuro, } \\
\text { argila mineralógica e } \\
\text { oxidos de ferro, isótico }\end{array}$ & $\begin{array}{l}60 \% \text {, vermelho escuro, } \\
\text { isótico, argila } \\
\text { mineralógica e oxidos } \\
\text { de ferro. }\end{array}$ & $\begin{array}{l}40 \% \text {, vermelho } \\
\text { amarelo, silassépica. }\end{array}$ \\
\hline Esqueleto & $\begin{array}{l}30 \% \text {, presença de } \\
\text { plagioclasio. Quartzo } \\
\text { subarredondado e } \\
\text { subangular, mal } \\
\text { selecionado ( } 70- \\
100 u m \text { ), presença de } \\
\text { alguns minerais opacos }\end{array}$ & $\begin{array}{l}\text { 15\%, Quartzo } \\
\text { subarredondado,mal } \\
\text { selecionado. Muitos } \\
\text { feldspatos e } \\
\text { plagioclasios do } \\
\text { diabásio. }\end{array}$ & $\begin{array}{l}20 \% \text {, Quartzo } \\
\text { subarredondado, } \\
\text { subangular e mal } \\
\text { selecionado. Presença } \\
\text { de bastantes } \\
\text { litoreliquias. }\end{array}$ & $\begin{array}{l}30 \%, \text { quartzo } \\
\text { subarredondado e } \\
\text { subangular, presença } \\
\text { grande quantiade de } \\
\text { litoreliquias. }\end{array}$ \\
\hline Poros & $\begin{array}{l}20 \% \text {, Predominio de } \\
\text { fissurais e } \\
\text { ortocavidadea presença } \\
\text { de alguns canais. }\end{array}$ & $\begin{array}{l}25 \%, \text { Predominio de } \\
\text { ortocavidades e canais, } \\
\text { e fissuras associados. }\end{array}$ & $\begin{array}{l}20 \% \text {, Predominio de } \\
\text { fissuras e } \\
\text { ortocavidades. }\end{array}$ & $\begin{array}{l}30 \%, \text { predominio de } \\
\text { fissuras e } \\
\text { ortocavidades. }\end{array}$ \\
\hline Trama & Porfírica & Porfírica & Porfírica & Porfírica fissurada \\
\hline Feições & $\begin{array}{l}\text { Presença de nódulos de } \\
\text { 4-5mm de diâmetro. }\end{array}$ & $\begin{array}{l}\text { Pedalidade moderada, } \\
\text { agregados } \\
\text { subangulares. }\end{array}$ & $\begin{array}{l}\text { Presença de pápulas e } \\
\text { ferriargilãs de } \\
\text { iluviação. } \\
\text { Pedalidade moderada a } \\
\text { forte, agregados } \\
\text { subangulares }(0,5 \mathrm{~mm} \text { a } \\
1 \mathrm{~mm}) \text {. }\end{array}$ & $\begin{array}{l}\text { Presença em alguns } \\
\text { pontos isolados de } \\
\text { stress-cutans. } \\
\text { Pedalidade moderada a } \\
\text { forte, agregados } \\
\text { subangulares }(0,5-1 \mathrm{~mm} \\
\text { de diâmetro) }\end{array}$ \\
\hline
\end{tabular}

Micromorfologia do Perfil 4. Classificação do solo: Terra Roxa Estruturada pouco profunda, eutrófico, A moderado, textura muito argilosa. 


\section{Apêndice 6}

ANÁLISES DE ZIRCÔNIO E TITÂNIO POR FLUORESCÊNCIA DE RAIO X E ANÁLISES DE QUARTZO POR DIFRATOMETRIA DE RAIO $X$. 
Dados de ferro, zircônio, titânio, quartzo e das relações $\mathrm{Zr} / \mathrm{Ti}$ e Zr/Qu do perfil 1 (P1).

\begin{tabular}{|c|c|c|c|c|c|c|c|}
\hline $\begin{array}{c}\text { Amostra } \\
\mathbf{N}^{\mathbf{0}}\end{array}$ & $\begin{array}{c}\text { Prof. } \\
\mathbf{c m} .\end{array}$ & $\begin{array}{c}\text { Ferro } \\
\%\end{array}$ & $\begin{array}{c}\text { Zircônio } \\
\%\end{array}$ & $\begin{array}{c}\text { Titânio } \\
\%\end{array}$ & $\begin{array}{c}\text { Quartzo } \\
\%\end{array}$ & $\mathbf{T i / Z r}$ & $\begin{array}{c}\mathbf{Z r} / \mathbf{Q u} \\
\left(\mathbf{x ~ 1 0} \mathbf{1}^{-5}\right.\end{array}$ \\
\hline 01 & $0-10$ & 13.61 & 0.0675 & 4.1 & 15 & 60.74 & 45 \\
\hline 02 & $10-40$ & 15.01 & 0.0585 & 3.93 & 22 & 67.18 & 26.6 \\
\hline 03 & $40-67$ & 14.79 & 0.0492 & 2.93 & 14.29 & 59.55 & 34.4 \\
\hline 04 & $67-115$ & 15.04 & 0.0568 & 3.39 & 49.5 & 59.68 & 11.4 \\
\hline 05 & $115-235$ & 15.56 & 0.0625 & 3.93 & 18.4 & 62.88 & 33.9 \\
\hline 06 & $235-285$ & 14.78 & 0.0618 & 3.75 & 9.4 & 60.68 & 65.7 \\
\hline 07 & $285-465$ & 14.74 & 0.0667 & 3.77 & 16.36 & 56.52 & 40.7 \\
\hline 08 & $465-480$ & 15.33 & 0.0525 & 3.46 & 15.1 & 65.90 & 34.7 \\
\hline 09 & $480-580$ & 15.73 & 0.0433 & 3.23 & 13.6 & 74.59 & 31.8 \\
\hline 10 & 630 & 14.35 & 0.0441 & 2.04 & 21.36 & 46.26 & 20.6 \\
\hline 11 & 680 & 15.75 & 0.0363 & 2.53 & 47.35 & 69.69 & 7.6 \\
\hline 12 & rocha & 11.12 & 0.0219 & 2.66 & - & 121.46 & - \\
\hline
\end{tabular}

Dados de ferro, zircônio, titânio e da relação $\mathrm{Zr} / \mathrm{Ti}$ do perfil 3 (P3).

\begin{tabular}{|c|c|c|c|c|c|}
\hline Amostra N $^{\mathbf{0}}$ & $\begin{array}{c}\text { Prof. } \\
\mathbf{c m}\end{array}$ & $\begin{array}{c}\text { Ferro } \\
\%\end{array}$ & $\begin{array}{c}\text { Zircônio } \\
\%\end{array}$ & $\begin{array}{c}\text { Titânio } \\
\%\end{array}$ & $\begin{array}{c}\text { Ti/Zr } \\
\end{array}$ \\
\hline 01 & 30 & 15.58 & 0.0509 & 4.18 & 82.12 \\
\hline 02 & 60 & 16.42 & 0.0452 & 3.35 & 74.11 \\
\hline 03 & 90 & 16.46 & 0.0431 & 3.21 & 74.47 \\
\hline 04 & 120 & 16.7 & 0.0448 & 3.35 & 74.77 \\
\hline 05 & 165 & 16.91 & 0.0541 & 3.65 & 67.46 \\
\hline 06 & 215 & 16.67 & 0.0501 & 3.18 & 63.47 \\
\hline 07 & 250 & 16.59 & 0.0387 & 2.58 & 59.37 \\
\hline
\end{tabular}

